UNIVERSIDADE DE SÃO PAULO

FACULDADE DE FILOSOFIA, LETRAS E CIÊNCIAS HUMANAS DEPARTAMENTO DE LETRAS CLÁSSICAS E VERNÁCULAS PROGRAMA DE PÓS-GRADUAÇÃO EM ESTUDOS

COMPARADOS DE LITERATURAS DE LÍNGUA PORTUGUESA

JOÃO CARLOS ZAN

RAMALHO ORTIGÃO E O BRASIL

SÂO PAULO

2009 
João Carlos Zan

\section{Ramalho Ortigão e o Brasil}

Tese apresentada à Faculdade de Filosofia, Letras

e Ciências Humanas da Universidade de São Paulo para obtenção do título de Doutor em Letras. Área de Estudos Comparados de Literaturas de Língua Portuguesa.

Orientadora: Profậ. Drậ. Elza Assumpção Miné

SÃO PAULO

2009 
In Memorian de

Ibrahim de Azevedo

por tudo que ele foi 


\section{Agradecimentos}

à Professora Doutora Elza Assumpção Miné, pelas lições, pelo estímulo e pela paciência na orientação deste trabalho;

às Professoras Doutoras Aparecida de Fátima Bueno e Cássia de Lima Santana, pela leitura interessada do relatório de qualificação;

à Professora Doutora Benilde Justo Lacorte Caniato (in Memorian) e à Professora Doutora Nadia Battella Gotlib, pelas oportunas sugestões;

à Carminha e à Marisa, atenciosas bibliotecárias, pela ajuda;

à Marie, solícita e incansável, pela diagramação;

à CAPES, pela bolsa concedida. 


\section{RESUMO}

ZAN, João Carlos, Ramalho Ortigão e o Brasil.2009. 278 f. Tese (Doutorado). Faculdade de Filosofia, Letras e Ciências Humanas Departamento de Letras Clássicas e Vernáculas - Programa de Pós-Graduação em Estudos Comparados de Literaturas de Língua Portuguesa, Universidade de São Paulo, 2009.

O propósito da presente tese é estudar os vínculos mantidos por Ramalho Ortigão, importante escritor da geração de 70, com o Brasil, notadamente com a imprensa dopaís. As suas conhecidas "Cartas Portuguesas", publicadas pela Gazeta de Notícias do Rio de Janeiro, de 12 de julho de 1877 a 17 de outubro de 1915, num total de mais de 500 colaborações, assim como a temporada de três meses que passou no Brasil, no segundo semestre de 1887, demonstram muito bem o quanto foram estreitos e produtivos estes vínculos.

A primeira parte do trabalho, de natureza histórico-analítica, compreende a apresentação e discussão de dados relativos às atividades jornalísticas do escritor, especialmente durante os anos de sua colaboração como correspondente em Lisboa da Gazeta de Noticias.

A segunda parte da tese apresenta toda a pesquisa realizada neste jornal, em cujas páginas se fez o levantamento total das matérias firmadas por Ramalho, além de uma amostragem de cartas, não encontradas em livros deste escritor.

Ao mapear pioneiramente toda a participação de Ramalho Ortigão na Gazeta de Notícias, a presente tese demonstra e atesta o importante papel por ele desempenhado na imprensa brasileira, sobretudo no último quartel do século XIX.

Palavras-chave: Ramalho Ortigão; Jornalismo e Litetratura; Jornalismo e História; Gazeta de Notícias; Imprensa portuguesa e brasileira. 


\begin{abstract}
ZAN, João Carlos, Ramalho Ortigão and Brazil. 2009. 278 f. Thesis (Doctoral). Faculdade de Filosofia, Letras e Ciências Humanas Departamento de Letras Clássicas e Vernáculas - Programa de Pós-Graduação em Estudos Comparados de Literaturas de Língua Portuguesa, Universidade de São Paulo, 2009.
\end{abstract}

The purpose of this thesis is to study the relations established between Ramalho Ortigão -- important Portuguese writer from the "Geração de 70" - with Brazil, particularly with the brazilian press. His well-known "Portuguese Letters", published in Rio de Janeiro by Gazeta de Notícias, from July $12^{\text {th }} 1877$ to October $17^{\text {th }} 1915$, summing more than 500 contributions, as well the three month period that he spent in Brazil in the second semester of 1877, demonstrate that this relationship was close and productive.

The first part of the thesis, that has an historical and analytical perspective, examines the writer's journalistic activities, especially during the period in wich he was a correspondent for Gazeta de Notícias.

The second part of the thesis presents the results of the research done in Gazeta de Notícias, with a comprehensive survey of all articles written by Ramalho.

A sample of letters that cannot be found in the author's books is also included in this documental part of the work.

Besides conducting a pioneering research of all Ramalho Ortigão's participation in that brazililan newspaper, the thesis demonstrates and confirms the important role he played in Brazilian press, especially in the last quarter of the nineteenth century.

Key-words: Ramalho Ortigão; Journalism and Literature; Journalism and History; Gazeta de Notícias; Portuguese and Brazilian Press. 


\section{Sumário}

Apresentação.

\section{Primeira parte}

A participação de Ramalho Ortigão na imprensa portuguesa e brasileira.....

1 - Ramalho Ortigão antes da Gazeta de Notícias.

1.1 - Nos tempos do Porto

- Dados biográficos..

- Princípios da carreira.

- Uma nova revista brasileira

1.2 - Nos tempos de Lisboa.

- Ramalho Ortigão e a Questão Coimbrã.

- O Cenáculo e as Conferências do Casino.

- A saída de Eça de Queirós.

- Outros trabalhos.

2 - O Brasil, a Gazeta de Notícias e Ramalho Ortigão.

2.1 - A reforma eleitoral brasileira

2.2 - O sufrágio universal.

2.3 - O gabinete Saraiva.

2.4 - As Notas de viagem de Ramalho Ortigão.................................. 79

2.5 - A exposição de Paris em 1878................................................. 87

2.6 - A instrução pública e Rodolfo Dantas ..................................... 92

2.7 - O movimento abolicionista........................................................ 95

2.8 - Joaquim Nabuco em Lisboa................................................ 111

3 - A viagem de Ramalho Ortigão ao Brasil............................................ 122

3.1 - O livro sobre o Brasil.............................................................. 126

3.2 - A Holanda na Gazeta de Notícias............................................. 133

3.3 - A expectativa do leitor brasileiro........................................... 139

3.4 - "O quadro social da revolução brasileira".................................. 144

3.5 - O Brasil visto por Ramalho............................................... 154

3.6 - A esquina dos séculos...................................................... 165

4 - As últimas "Cartas Portuguesas" ...................................................... 175

4.1 - O reinado de D. Manuel II.................................................. 175

4.2 - A revolução republicana em Portugal...................................... 177

4.3 - A retomada da correspondência para o Rio de Janeiro............... 180

4.4 - As últimas cartas e as Últimas farpas..................................... 183

4.5 - Cartas enviadas de Lisboa............................................... 184

4.6 - Cartas enviadas de Paris.......................................................... 197

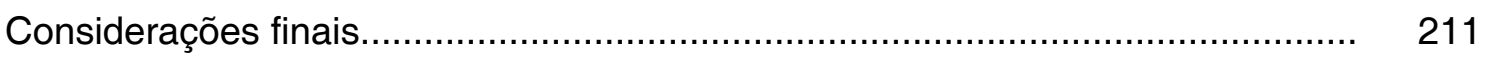




\section{Segunda parte}

A colaboração de Ramalho Ortigão na Gazeta de Notícias (1877-1915)

Primeiras considerações................................................................................... 215

1 - Convenções estabelecidas para o registro das ocorrências de matérias assinadas pelo escritor.

2 - Quadro geral das colaborações do autor publicadas pela Gazetade Notícias.

3 - Relação das colaborações publicadas na Gazeta de Notícias e recolhidas em livros do autor.

4 - Quadro comparativo do número total de colaborações publicadas anualmente com o número de colaborações não encontradas em livros do autor.

5 - Pequena amostragem de colaborações inéditas em livros do autor.

5.1 - Domingo, 21 de setembro de 1879

5.2 - Terça-feira, 28 de setembro de 1880

5.3 - Sexta-feira, 16 de março de 1883

5.4 - Terça-feira, 26 de maio de 1885.

5.5 - Segunda feira, 27 de julho de 1891 


\section{Apresentação}

Muitas coisas foram encontradas no baú deixado por Fernando Pessoa. Muitas coisas também poderiam ser encontradas em um baú com a seguinte inscrição: Ramalho Ortigão e o Brasil. O trabalho que ora se apresenta poderia perfeitamente se achar entre elas. E seria apenas mais uma dentre tantas outras possíveis. Justamente por saber disso, por saber que há muitos caminhos a serem trilhados na relação deste homem com este país, foi que em momento algum se teve a pretensão de esgotar o tema. Fez-se uma escolha consciente de que haveria ainda outros caminhos a serem percorridos.

E uma vez feita a escolha, optou-se por dividir o trabalho em duas partes: uma histórico-analítica, de cunho marcadamente biográfico e outra documental, tendo por base os textos enviados pelo escritor à Gazeta de Notícias do Rio de Janeiro.

A parte histórico-analítica foi, por sua vez, subdividida em quatro capítulos. O primeiro deles, intitulado "Ramalho Ortigão antes da Gazeta de Notícias", tem por objetivo dar uma idéia do que foi a carreira literária e jornalística do escritor, antes de seu ingresso no quadro de colaboradores da Gazeta de Notícias, fase que mais diretamente interessa a este trabalho. Deuse prioridade, neste capítulo, ao período de formação do escritor, buscando-se mostrar a sua importância e o lugar que vinha ocupando no jornalismo português; e, por isso mesmo, quase todo o enfoque recai sobre a figura do próprio autor, ficando o Brasil como um pano de fundo.

Como neste período há duas fases distintas na vida do escritor, o capítulo apresenta dois tópicos. O primeiro deles trata dos tempos em que Ramalho ainda vivia na cidade do Porto, repartindo-se entre as aulas no Colégio da Lapa, onde ensinou francês a Eça de Queirós, e os folhetins semanais publicados pelo O Jornal do Porto, do livreiro Cruz Coutinho. Boa parte deste material está recolhida nos volumes Primeiras prosas e Crônicas portuenses. É a fase inicial de sua vida de escritor, compreendendo dez anos da carreira iniciada em 1857. O segundo tópico focaliza os primeiros tempos de 
sua vida em Lisboa, para onde seguiu com a família em fins de 1867. compreende também esta fase um período de aproximadamente dez anos, durante os quais se pode destacar correspondências enviadas para o jornal $O$ Progresso do Porto e o seu encontro com Eça de Queirós. Do material enviado ao periódico portuense, após cuidadosa seleção, foram editados os volumes I e II de Correio de hoje. Do seu encontro com o ex-pupilo resultaram os folhetins de O mistério da estrada de Sintra e os primeiros opúsculos de As farpas.

A concepção que balizou a elaboração deste capítulo foi basicamente mostrar que o escritor português não era nenhum principiante querendo se firmar profissionalmente, quando aceitou o convite para colaborar na imprensa brasileira.

No segundo capítulo, intitulado "O Brasil, a Gazeta de Notícias e Ramalho Ortigão", o foco se desloca do escritor para o país que recebia as primeiras cartas por ele enviadas. Daí aparecerem neste capítulo os nomes de alguns jovens que ingressavam na vida pública, principiando a carreira que os levaria mais tarde à categoria de personagens da história política e literária do Brasil. É o caso, por exemplo, de Joaquim Nabuco cuja recepção pelo parlamento português foi tema de uma das "Cartas Portuguesas" publicadas pelo jornal brasileiro. Aparece aqui também, e é tratado, o livro Notas de viagem, resultado da recolha das colaboracões enviadas de Paris sobre a Exposição Universal de 1878, publicadas em uma seção que tinha este mesmo nome.

O terceiro capítulo intitula-se "A viagem de Ramalho Ortigão ao Brasil”, e, como se deduz do próprio título, trata da viagem do escritor ao país, no segundo semestre de 1887, quando, hóspede de seu irmão Joaquim, passou no Brasil, em companhia da esposa e de uma de suas filhas, uma temporada de três meses. Algumas das impressões colhidas nesta viagem estão registradas no ensaio intitulado "O quadro social da revolução brasileira", escrito em dezembro de 1889, com publicação na Revista de Portugal e, em segunda mão, na Gazeta de Notícias. Tanto o ensaio quanto o livro A Holanda - outra recolha de textos publicados na seção denominada "Notas de viagem" são comentados neste capítulo da tese. Fez-se também o registro da enorme 
expectativa criada pela notícia que se espalhou da possível edição de um livro sobre o Brasil, escrito por Ramalho Ortigão.

Quanto ao tempo decorrido, estes três capítulos perfazem, aproximadamente, uns trinta anos da carreira jornalística de Ramalho Ortigão, período de vida que constitui a fase mais representativa de toda sua colaboração para o diário brasileiro.

As últimas "Cartas Portuguesas" enviadas pelo escritor à Gazeta de Notícias constituem o tema do quarto capítulo. Publicadas bem no princípio do segundo decênio do século $X X$, tratam quase que exclusivamente da revolução republicana portuguesa, ocorrida em outubro de 1910. Decorre a sua importância do fato de serem estas cartas as últimas colaborações enviadas pelo escritor ao diário brasileiro, além de representarem uma espécie de ressurgimento do correspondente após uma certa ausência. Postumamente, foram elas recolhidas em livro que se publicou com o título de Últimas farpas.

Estes quatro capítulos foram concebidos segundo uma orientação cronológica, para que se evidenciasse a trajetória de Ramalho como jornalista e se avaliasse a importância nela desempenhada pela ligação com o Brasil.

A segunda parte da tese compreende um levantamento rigoroso e exaustivo de todas as colaborações de Ramalho Ortigão para a Gazeta de Notícias, do Rio de Janeiro.

Os resultados de tais buscas de caráter documental acham-se apresentados em diferentes quadros: um quadro geral das colaborações do escritor publicadas pela folha carioca, no qual são apontados o ano e o número do jornal, a data e a seção em que foi publicada a colaboração, o local e a data da emissão, assim como o título, quando constantes, e, na ausência deste, o assunto abordado pela carta, além das palavras iniciais de cada colaboração; um quadro das colaborações publicadas na Gazeta de Notícias e recolhidas em livros do autor, em que se apontam a data da publicação no diário brasileiro, o título da obra em que foram coligidas e o número da página em que se iniciam nas respectivas coletâneas; uma pequena amostragem das 
colaborações não localizadas nos livros do autor, assumidas , portanto, como inéditas em livro.

Ao final do trabalho se encontra a bibliografia utilizada. 


\section{PRIMEIRA PARTE}

A participação de Ramalho Ortigão na imprensa portuguesa e brasileira 


\section{1 - Ramalho Ortigão antes da Gazeta de Notícias}

\section{1 - Nos tempos do Porto}

Se, por um lado, fosse fixada a data de 12 de julho de 1877, quando a Gazeta de Notícias estampou pela primeira vez em suas páginas uma das "Cartas Portuguesas"1, como o marco temporário inicial e, por outro lado, a data de 17 de outubro de 1915, quando publicou a última, como o marco temporário final, a fim de se proceder à contagem do tempo em que Ramalho Ortigão colaborou, com exclusividade ou não, no diário brasileiro, o decurso deste tempo registraria um período extraordinário de 38 anos de atividade.

Evidentemente que, assim como as de Eça de Queirós, suas colaborações para o matutino carioca não foram ininterruptas, mas seja lá como for, mesmo nas fases de mais prolongada ausência, ambos jamais deixaram de ser considerados como jornalistas da Gazeta. Eram verdadeiramente tidos como "pratas da casa" e a qualquer pretexto seus nomes apareciam nas páginas do jornal, seja nos anúncios que muitas vezes se repetiam dias seguidos antes da publicação de suas colaborações, seja no expediente, onde normalmente figuravam como correspondentes estrangeiros, seja em artigos de outros articulistas, que, muitas vezes, apoiavam-se em pontos de vista defendidos por eles.

Esta hipótese de "prata da casa", tendo seu nome intimamente ligado ao diário brasileiro, transparece e se evidencia na seguinte ocorrência: durante todo o mês de dezembro do ano de 1900 e praticamente todo o mês de janeiro do ano seguinte foi diariamente anunciado nas páginas da Gazeta de Notícias que Ramalho Ortigão - ausente desde 1895 - voltaria a enviar

\footnotetext{
${ }^{1}$ Foi este o principal título da seção que abrigou as colaborações de Ramalho Ortigão para a Gazeta de Notícias. Embora houvesse outros, foi sob o título de "Cartas Portuguesas" que se publicou a grande maioria de suas colaborações.
} 
colaborações para o jornal ${ }^{2}$. Em fins de janeiro o anúncio foi retirado, voltando a aparecer somente no dia 20 de fevereiro. Sua primeira colaboração, no entanto, só apareceria nas páginas do jornal no dia 28 de setembro de 1901. Após um bombardeio de mais de cinqüenta anúncios, sete meses de silêncio.

O porquê de tanta demora na publicação não se sabe, e tampouco vem ao caso, interessando apenas o fato, que permite supor ou até mesmo presumir que o leitor (talvez nem tanto quanto o pesquisador), durante todo este tempo, esteve na expectativa de que a assinatura de Ramalho Ortigão aparecesse a qualquer momento, nas páginas do jornal, firmando alguma matéria. É este apenas um exemplo a ilustrar a idéia de que, mesmo nos períodos de ausência, o nome do escritor permanecia vivo na memória do leitor brasileiro.

Podia também acontecer o caso de o diário brasileiro republicar notícias ou informações de jornais portugueses que diziam respeito ao escritor, como ocorreu, por exemplo, com a carta-anúncio da morte de Eduardo Prado.

Ao tomar conhecimento por telegrama do falecimento do amigo, Ramalho imediatamente enviou uma nota de esclarecimento aos jornais portugueses. A Gazeta de Notícias então reproduz textualmente, na sexta coluna da segunda página, esta nota em forma de necrológio. Foi esta uma das primeiras homenagens a ele prestadas em Lisboa, uma cidade que Eduardo Prado considerava quase como sendo sua, pelo expressivo círculo de amizade que calorosamente sempre o recebeu. Nesta carta aberta, que os jornais portugueses publicaram, Ramalho Ortigão dispensa a Eduardo Prado o tratamento de "muito prezado amigo", revelando, de maneira franca e inequívoca, verdadeira afeição por ele. E não há por que supor ter sido insincera ou demagógica esta manifestação de carinho. Foi de todos bastante conhecida a amizade que os uniu pelas tantas vezes que estiveram juntos em Paris, em Lisboa, em viagens pelo mundo.

Este outro exemplo envolvendo o nome de Ramalho, é um caso típico de republicação ou reaproveitamento de matéria feito pelo jornal, cuja

\footnotetext{
${ }^{2}$ Era o seguinte o teor do anúncio: "Este notável escritor, antigo colaborador da Gazeta, já comunicou à empresa a sua resolução de continuar a honrar a Gazeta com a sua preciosa colaboração."
} 
inserção em suas páginas não seguiu as normas comumente utilizadas para o escritor, a quem sempre foi reservado um espaço nobre na primeira página. Tinha ele a sua própria seção. "Notas de viagem", "Jornal de um Lisboeta", "Impressões Portuguesas" foram algumas delas, porém, como já se frisou, a mais conhecida, talvez por ser a mais divulgada, foi sem sombra de dúvida a seção intitulada "Cartas Portuguesas". Publicadas - nos primeiros anos de sua colaboração - no espaço reservado aos folhetinistas, constituem estas cartas verdadeira marca registrada de Ramalho Ortigão. Páginas de imprensa que aproveitou para revelar talento e versatilidade, abordando temas variados que, por mais complexos que fossem, sabia, como poucos, a melhor maneira de torná-los simples aos olhos de seu leitor.

E se acaso veiculavam informações ou conceitos novos, procurava honestamente justificá-los com os conhecimentos e descobertas científicas da época. Foi tamanha esta preocupação em Ramalho que se tornou uma fraqueza, um senão que muito prejudicou seu estilo, envelhecendo e empanando o brilho de alguns textos. Por causa dela se tornaram arrastados, pesadões, cansativos e de pouco interesse para um leitor familiarizado com as descobertas do mundo de hoje, muito embora perfeitamente justificável para a época e para um autor com pretensões de colocar ao alcance de todos as últimas descobertas da ciência.

De maneira geral, todos os campos do conhecimento interessavam a Ramalho Ortigão, notadamente aqueles que mais diretamente estivessem relacionados com o ser humano. Sobre todos, porém, procurava se informar para levar as informações adquiridas ao conhecimento do leitor. la dos costumes sociais, das questões religiosas, dos aspectos da instrução à adubação química ou à doença da videira e, mesmo não sendo especialista, procurava embasar a sua argumentação em fontes fidedignas, selecionadas por ele ou sugeridas por outros.

Foi durante toda a sua vida um leitor incansável, procurando sempre se manter atualizado e a par dos principais movimentos científicos de seu tempo. Teve como seu o firme propósito de distribuir informações e levar ao conhecimento de todos as últimas descobertas da ciência, delas se utilizando para ensinar o leitor a se alimentar melhor, a adquirir hábitos de 
higiene com preocupações profiláticas, educar os filhos pelos métodos mais modernos ou, corriqueira e trivialmente, ensinar o leitor a escolher o calçado mais apropriado à proteção dos pés em uma boa e saudável caminhada.

\section{Dados biográficos}

Nascido no Porto a 25 de novembro de 1836, filho de Joaquim da Costa Ramalho Ortigão, primeiro-tenente de artilharia do exército de D. Pedro IV e diretor-proprietário do Colégio da Lapa, e de dona Antonia Alves Duarte Silva, de origem alentejana e algarvia, José Duarte Ramalho Ortigão possuía uma cultura invulgar, que, ao longo da vida e da obra, procurou compartilhar, primeiro, com os portugueses e depois com os brasileiros. A sua obra - um conjunto de folhetins, opúsculos, crônicas e cartas, umas editadas em livro, outras ainda inéditas - representou, para a época, verdadeiro libelo contra os maus costumes que procurou reformular, fossem eles sociais ou políticos, tudo, porém, sem o azedume e a maledicência de um Fialho de Almeida, e, sim, temperado com o humor e a ironia de um Eça de Queirós, do qual foi não só professor como discípulo.

Mas, acima de tudo, Ramalho foi um dos mestres da descrição em língua portuguesa. Ver e descrever constituiu o supra-sumo de sua arte e, para tanto, mobilizou um riquíssimo vocabulário, que soube utilizar como poucos, encontrando sempre o termo justo, o vocábulo certo, que se engastava como gema em uma prosa simples, fluente e natural que serviu de modelo e paradigma a muitos aprendizes do idioma. Além disso, dispôs de uma memória fotográfica e de um senso de observação tão apurado que, muitas vezes, tornavam significativos pequenos detalhes que a outros passariam despercebidos.

Pelo seu amor da observação minuciosa, adquire e arquiva na sua memória uma quantidade prodigiosa de pequenos fatos, matéria, feitio, proveniência, qualidades, preços, uso dos objetos, fisionomia, gestos, naturalidade, ocupação, relações, gostos, costumes, 
vestuário das pessoas e mais uma profusão de receitas, conselhos, contas, casos de experiência caseira e sabedoria prática, tudo afogado num dilúvio de anedotas através do qual sorri animada a sua bela face de gigante amável. ${ }^{3}$

Esta prosa culta, rica e abundante era mobilizada para servir a um ideal de reforma. Preocupado com o atraso do país pôs a serviço de seus contemporâneos todo um cabedal de conhecimentos acumulados, práticos ou teóricos. Por considerar sumamente importante no processo de transformação de qualquer sociedade o aprimoramento do homem em si, pôs sua literatura a serviço do esclarecimento, da instrução e da orientação, principalmente, do povo.

Até os sete anos de idade, o menino José Duarte foi criado em casa de sua avó materna, viúva e lavradora, em uma quinta do Porto, a mesma casa em que nascera e onde também viviam seu padrinho e tio-avô, frei José do Sacramento, suas duas tias solteiras e seu criado Manuel Caetano, soldado reformado do Batalhão de Veteranos, um agregado que ajudava a trabalhar a terra. Quinta de produção e não de recreio, garantia o sustento de todos, suprindo a despensa com ovos frescos, legumes, hortaliças, leite puro e carne que comiam ao menos três vezes por semana; mas que a par disso servia de recreio ao menino que incansavelmente perseguia, pelos campos, armado de alçapões, melros e rouxinóis. Com as mulheres da casa, Ramalho diz ter aprendido a "ser resignado e sóbrio"4 e da convivência com os homens - um religioso e um militar - mais tarde, intimamente, reconheceu terem sido determinantes na formação de seu caráter: "Ficaram-me, de pequeno, indestrutíveis gostos de ordem, de disciplina, de solidão"5.

$\mathrm{Na}$ convalescença de uma febre escarlatina contraída na puberdade, ganhou de sua mãe As viagens na minha terra. A leitura desta obra de Almeida Garrett marcou profundamente o rapaz e foi determinante para seu futuro e para a escolha da carreira.

\footnotetext{
${ }^{3}$ Teófilo Braga, História da literatura portuguesa, v. V, pp. 398, 399.

${ }^{4}$ Ramalho Ortigão, Folhas soltas, p. 294.

${ }^{5}$ Idem, Costumes e perfis, p. 139.
} 
Ficou-me de cor, penetrou-me inteiramente, entrou-me para assim dizer na composição do cérebro e na massa do sangue esse livro de um encanto tão sugestivo e tão avassalante. Então se fez em mim o clarão mais estranho. Então compreendi, e vi, que fora das courelas da minha família - pelo lado físico, fora dos hábitos dos meus amigos - pelo lado moral, havia um mundo novo: um poder mágico - o da evocação artística; e do decorrer dessa paisagem do Ribatejo, tão penetrantemente portuguesa, tão aviventada de idéias e de sentimentos, na Alhandra, em Vila-Franca-de-Xira, no Cartaxo, no Vale de Santarém, ondulada de searas, verdejante de vinhas, gorgeada de rouxinóis, no murmúrio das azinheiras e dos olivais, uma noção nova me veio - a noção da pátria. Desde esse dia - agora o compreendo bem - o meu destino estava fixado. Bom ou mau, eu tinha de ser fatalmente um escritor. ${ }^{6}$

É possível, também, que venha daí o gosto pelas viagens que o acompanhou por toda a vida, tanto as viagens pelas províncias de seu país como pelas terras estrangeiras; tema, aliás, muito abundante no rol de suas colaborações para a Gazeta de Notícias.

Palmilhador incansável de estradas, trilhas e caminhos de Portugal, desabafa, defendendo-se, em carta a Alberto de Oliveira, da acusação de só se deslumbrar perante terras alheias. Para tanto, envia-lhe um volume de As farpas em que trata apenas da paisagem portuguesa e, sombranceiramente, no texto da carta, lembra ao jovem colega que:

Não há monte nem vale nem rio nem ribeira, por esse Portugal todo, que eu não percorresse, por simples namoro, sem nenhum outro fim de interesse ou de curiosidade, à minha custa, em caminho de ferro, em diligência, embarcado, a cavalo e a pé. Por amor palmilhei repetidas vezes a serra de Ossa, da Arrábida, de Monchique, subi o Marão e subi a Serra da Estrela. Por amor dormi ao relento na lezíria do Ribatejo. Por amor andei a monte na serra da Talhadas e no rego de Chave, e pernoitei deitado nas manjedouras, sobre o retraço

\footnotetext{
${ }^{6}$ Ibidem, pp. 140, 141.
} 
dos machos, em Albergaria das Cabras, na Trapa e na Farrapa. Por amor me banhei no Douro, no Minho, no Ave, no Vouga, no Homem, no Cávado, no Mondego e no Guadiana. ${ }^{7}$

Uma curiosidade que se encontra nesta carta de Ramalho a Alberto de Oliveira é a informação de ter sido a morte de Garrett o tema de seu primeiro artigo, um trabalho que, muito provavelmente, não foi publicado, pois que dele não há menção em nenhum outro lugar.

Aos quatorze anos de idade Ramalho Ortigão seguiu para Coimbra a fim de matricular-se no curso de Direito daquela Universidade, mas abandonou a idéia após os exames preparatórios e, voltando à cidade natal, passou a lecionar francês no colégio do pai - "oficina modelar de ensino e disciplina da puerícia"8 - onde foi professor dos meninos Eça de Queirós e Ricardo Jorge. Este famoso higienista, lente da Escola Médico-cirúrgica de Lisboa e um dos fundadores da Revista Científica, foi autor de inúmeros trabalhos sobre Epidemiologia, além de estudos sobre língua, literatura e cultura portuguesa, inclusive um livreto sobre seu antigo mestre de francês. Escrito em Vidago ainda sob o impacto da notícia da morte de Ramalho Ortigão, ocorrida dois dias antes, o opúsculo guarda sentidas recordações da infância do higienista, sobressaindo-se neste mundo pueril a figura do mestre: "alto, espadaúdo e desempenado"9. As passadas firmes, os gestos largos e a estampa vigorosa de homem saudável profunda impressão causaram no menino que desde então passou a tê-lo na conta do "justo e feliz a quem os signos fadaram do berço com a robustez, o espírito, o caráter e a alegria"10.

E tinha razão Ricardo Jorge, pois que não há lugar em sua obra para a tristeza e a melancolia, estados de alma que Ramalho - até com certo exagero - diagnosticava como debilidade orgânica ou moléstia adquirida, ambas passíveis de tratamento a seu modo de ver. Mas, se em sua obra é escasso o sentimento de tristeza é abundante o sentimento de justiça, pela qual se bateu ao longo de toda a carreira. Procurou ser justo até mesmo com

\footnotetext{
${ }^{7}$ Rodrigues Cavalheiro, A evolução espiritual de Ramalho, pp. 27, 28.

${ }^{8}$ Ricardo Jorge, Ramalho Ortigão, p. 4.

${ }^{9}$ Ibidem, p.7.

${ }^{10}$ Ibidem, p.8.
} 
os desafetos e raros são os casos em que esta norma de conduta não foi observada.

Ricardo Jorge foi dos derradeiros alunos de francês de Ramalho Ortigão e como Eduardo Prado leitor, desde os tempos de colégio ${ }^{11}$, de As farpas, por ele considerado "o mais violento sacão vibrado à modorra estuporal do indígena" ${ }^{2}$. Ainda menino conheceu os folhetos publicados por Eça e Ramalho, os opúsculos que a cada mês renovavam o interesse de jovens leitores como ele e Eduardo Prado.

Por questões de pronúncia e dicção, cabia a ele a incumbência de ler As farpas a senhoras e meninas reunidas aos sábados em serões de família na Rua do Almada - casa de um amigo, cuja mãe, leitora crítica, logo se havia encantado com aqueles folhetos que, além das novidades, traziam um diabo faceto estampado na capa.

Cada folheto explodia como uma granada luminosa e incendiária; abria clareiras de luz e arrasava a cama sedimentada e fortificada da rotina, do prejuízo e da asneira. Uma revelação e uma revolução: jamais a letra de forma as trouxera assim à literatura e à sociedade portuguesas. Sucesso sem precedentes, inédito e inaudito. ${ }^{13}$

Repentinos e vitoriosos, espantavam, seduziam e dominavam como verdadeiros conquistadores, causando agitação sobretudo entre as camadas mais novas da população. E o higienista não esconde, neste folheto que escreveu em homenagem ao velho mestre, a volúpia com que aquelas leituras o deleitavam.

\section{Princípios da carreira}

Aos vinte anos, Ramalho Ortigão começou a escrever em 0 Jornal do Porto, fundado por José Barbosa Leão e Antônio Rodrigues da Cruz

\footnotetext{
${ }^{11}$ Ramalho Ortigão, Cartas a Emília, p. 121.

${ }^{12}$ Ricardo Jorge, op. cit., p. 25.

${ }^{13}$ Ibidem, pp. 25, 26.
} 
Coutinho, proprietário de uma pequena loja de livros na Rua dos Caldereiros, local propício a reuniões e concílios de literatos. O honrado Cruz Coutinho, como era tido por todos, acabou mais tarde se tornando o único proprietário da folha portuense. Ramalho traça-Ihe um perfil, repassado de graça e nostalgia, em uma das edições de As farpas, matéria que foi também publicada na Gazeta de Notícias. É uma sentida - mas não melancólica - homenagem a Cruz Coutinho, na qual Ramalho consegue com imaginação e espírito caracterizar e por em pé a altiva figura do proprietário de O Jornal do Porto, que acabava de falecer.

Da homenagem ao antigo livreiro valeu-se o autor para recordar os bons tempos de moço, lembrança repassada de nostalgia e de saudades da velha cidade do Porto e dos velhos amigos de redação do jornal onde principiou sua carreira jornalística, uma carreira que só conheceu a ascensão e o sucesso e que o colocou ao lado dos maiores escritores de sua geração. 0 famoso e tantas vezes reproduzido retrato do grupo dos cinco é um documento que pode muito bem servir de respaldo a esse juízo.

Era Ramalho, na folha de Cruz Coutinho, o articulista responsável pelo noticiário e o folhetim, pela crítica de arte e as novidades, ou, como ele próprio lembra, a sua principal função naquele diário era representar "os papéis de galã de boca de cena na companhia da redação"14.

Quedas de governo, ruínas de tronos, desabamentos de altares provocados por bombas, intrigas, traições ou camartelos de iconoclastas não Ihe diziam respeito, pertenciam à órbita exclusiva do artigo de fundo. Agora, se fosse levada a cena uma nova peça, se fosse apresentado o programa de um novo concerto, se houvesse um baile, ou ainda se ocorresse a apresentação na cidade de bailarinos, cantoras ou atrizes, aí sim, aí era sua vez de calçar as luvas e, a primor, entrar em cena para a campanha. Como ele mesmo diz: "O redator político soprava as grossas notas campanudas e (...) eu flauteava as ligeiras variações agudas" 15 .

\footnotetext{
${ }^{14}$ Ramalho Ortigão, Costumes e perfis, p. 244.

${ }^{15}$ Ibidem, pp. 244, 245.
} 
Era aquele, sem sombra de dúvida, um posto que tão bem se ajustava à vaidade de moço elegante, desempenado e bem constituído que sonhava em saber-se lido e admirado, principalmente pelas leitoras.

Nos primeiros anos um feminismo, que estava talvez em germe no meu temperamento, mas que a leitura de Garrett na psicose da minha puberdade contribuiu muito para desenvolver num sentido romanesco, levava-me a apetecer um certo gênero de celebridade: que as mulheres me lessem, me olhassem com simpatia. ${ }^{16}$

Mais tarde, como ele confessa, esvaiu-se até mesmo esse sonho de saber-se lido com simpatia e admiração por mulheres bonitas, restando apenas a própria essência da escrita como único prazer de escrever, isto é, a satisfação pura e simples de conseguir, em uma ou outra linha, "fixar a imagem dum sentimento verdadeiro, transmitir uma emoção sincera"17.

Do corpo de redatores da folha portuense lembra Ramalho a figura reta e impoluta de José Luciano de Castro, advogado estabelecido no foro da cidade, que já havia sido deputado e, posteriormente, chegou a chefe de bancada e ministro da coroa. Era o autor dos artigos de fundo, elaborados com muito tato, muita finura e especial erudição, servindo com rara perícia e senso de oportunidade aos propósitos políticos do jornal e aos interesses financeiros de seu diretor.

Ramalho, em outro artigo de lembranças dos tempos de $O$ Jornal do Porto, artigo escrito em 1914 e dedicado à memória deste velho amigo que vinha de falecer, confessa com rigorosa modéstia a sua então incapacidade para a compreensão daquilo que José Luciano e Cruz Coutinho denominavam "os negócios públicos". Quem lê o texto percebe que ele se subestimava para melhor realçar os valores do outro, no caso, José Luciano, com sua habilidade e perícia na elaboração do artigo de fundo, que invariavelmente saía em conformidade com a linha editorial da folha e com a posição política adotada por Cruz Coutinho.

\footnotetext{
${ }^{16}$ Ibidem, pp. 141, 142.

${ }^{17}$ Ibidem, p. 141.
} 
Confessa ainda Ramalho, com aquela mesma rigorosa modéstia, não ter conseguido jamais atinar com a política do jornal, sempre se constituindo em verdadeiros fiascos os seus desempenhos quando eventualmente se via na obrigação de substituir José Luciano para elaboração do artigo de fundo. Destas tentativas resultaram quase sempre admoestações do diretor do jornal, que julgava mesmo espantosa a falta de tato de seu folhetinista quanto à orientação da casa: "Você parece que nem sequer lê o jornal!...."18, argumentava ele. Entre a zomba e o cinismo Ramalho contrapunha:

Não é para ler o jornal que eu me acho sentado a esta mesa, em frente de um tinteiro e de meia resma de papel almaço. $\mathrm{O}$ meu compromisso, como você sabe, é unicamente de escrever. ${ }^{19}$

Desolado e com a edição comprometida pelo artigo de fundo escrito por Ramalho que muito provavelmente conhecia, sim, a linha editorial do jornal, mas dela devia discordar e não desejava se comprometer, Cruz Coutinho, irresoluto, sentenciava a seu colaborador: "Não (...) você não pode passar de galã!"20.

Quem, com rara habilidade e extrema perfeição, imitava José Luciano na redação do artigo de fundo era o padre Francisco de Paula Mendes, responsável no jornal pela revista estrangeira. Ramalho diz categoricamente que se tratava de um literato consumado, de um escritor de raça, de um profissional favorecido por uma rara aptidão natural. Diz mais: que possuía um grande talento que, por submissão aos dogmas impostos pelo sacerdócio, tudo fazia para esconder, como se isso representasse uma arma proibida, ou não passasse, aos olhos de seus semelhantes, de uma impiedade, de um vício profano e sacrílego. Nunca em sua curta vida (morreu aos 43 anos de idade) assinou qualquer de seus artigos e, tampouco, jamais consentiu que associassem seu nome senão com a explícita condição de padre, membro da clerezia e beneficiário da Sé. "A literatura era para ele como a casa clandestina em que só entrava esquivando-se na sombra, com a cara coberta" ${ }^{21}$.

\footnotetext{
${ }^{18}$ Ramalho Ortigão, Folhas soltas, p. 332.

${ }^{19}$ Ibidem, p. 333.

${ }^{20}$ Idem, As farpas, v.III, p. 69.

${ }^{21}$ Ibidem, p. 68.
} 
Cruz Coutinho, que tinha por ele paternal carinho e singular admiração, custeou-lhe todo tratamento contra a tuberculose na llha da Madeira, para onde seguiu, após breve temporada no campo, pelos arrabaldes do Porto. Além disso, destacou para acompanhá-lo Manuel Fernandes Reis, funcionário do jornal que, além de amigo e companheiro do padre Mendes, tinha a grande vantagem de ter sido, antes de ingressar na empresa, oficial da Marinha Mercante. E fez mais ainda, mantendo para as irmãs do padre, que dele dependiam, o salário por ele recebido enquanto foi redator do jornal. Não é à toa que Ramalho sempre que se refere ao livreiro não se esquece de acrescentar: o "honrado" Cruz Coutinho.

Seriam José Luciano e o padre Mendes os dois primeiros grandes mestres de Ramalho, aos quais não deixou de prestar as devidas homenagens? É bem provável, uma vez que após a convivência com aqueles dois suas responsabilidades jornalísticas aumentaram e, daí em diante, seus encargos, em outros órgãos de imprensa pelos quais passou, jamais se restringiram simplesmente aos folhetins literários e aos noticiários locais.

A grande facilidade que o padre Mendes encontrava para a construção de seus artigos, de lógica pura e expressão perfeita, independentemente dos assuntos que lhe eram propostos, estabelecia rigoroso contraste com a dificuldade encontrada por Cruz Coutinho - escrupuloso revisor de provas e manuscritos dos correspondentes - de arquitetar e construir ele mesmo o arcabouço completo de um artigo, com princípio, meio e fim. Ramalho Ortigão, que com ele conviveu por volta de uns dez anos, conta, com graça e jocosidade, que de quando em quando vinha-lhe à idéia e dava-lhe na veneta a tentação de escrever ele próprio o seu artigo.

Encerrava-se para esse efeito num quarto da redação, que fechava por dentro a chave, mandando esperar à porta o moço encarregado de levar o autógrafo à tipografia. Uma hora depois reaparecia à fresta da porta entreaberta, trazendo um lenço de seda da China amarrado à cabeça por baixo do chapéu alto, que não tirava nunca, e encarregava o moço de lhe ir comprar bolachas, porque começava a enfraquecer. Entreabria a porta mais algumas vezes para fazer reforçar a sua provisão de charutos ou de rapé, ou para que lhe 
trouxessem de casa umas chinelas, até que ao cair da noite se desencerrava definitivamente, trazendo seis ou oitos linhas escritas no alto de um linguado, e dizendo a um dos seus redatores:

- Aí está o princípio do artigo, que era o mais difícil de fazer. Continue você no mesmo estilo - coisa aí para coluna e meia a duas colunas - e mande-me as provas a casa para eu harmonizar. ${ }^{22}$

Este homem que engrossara as fileiras patuléias do Partido Popular na Revolução Setembrista de 1836, defendendo galhardamente o posto de capitão das guardas nacionais, comedido e equilibrado em tudo mais na vida, "era absorvido completamente pela vaidade mais estranha e mais pueril: - a vaidade de parecer escritor"23. E muito provavelmente este desejo imoderado, esta presunção fútil e vã de ser visto também como escritor, ao lado dos demais escritores de seu jornal, fosse o principal, senão único, motivo para a norma imposta à sua folha de serem obrigatoriamente anônimos todos os artigos, com exceção do folhetim ${ }^{24}$.

Mas, este anonimato constituía um segredo de polichinelo, quase impossível de se guardar naquele acanhado meio jornalístico e, por isto mesmo, quando um articulista qualquer de outro periódico citava o nome de um dos seus redatores - que ele por força queria anônimo - isto, para ele, significava mais que deslealdade, era verdadeiramente uma traição imperdoável, mesmo que se tratasse de uma referência elogiosa. "É desacreditar o jornal! - berrava ele deitando o chapéu para a nuca - é tirar-lhe a força!"25.

E se alguém tentava convencê-lo do contrário, alegando, por exemplo, que o jornal não poderia ser desacreditado simplesmente por que um de seus redatores escrevia com talento e desenvoltura; que isto representava, sim, mais um louvor que um descrédito, aí então era que seu pronto destempero se mostrava verdadeiramente sintomático.

\footnotetext{
${ }^{22}$ Ibidem, pp. 64, 65.

${ }^{23}$ Ibidem, p. 70.

${ }^{24}$ Assim mesmo vários folhetins escritos por Ramalho Ortigão foram publicados sem a sua rubrica.

${ }^{25}$ Ramalho Ortigão, As farpas III, p. 70.
} 
- Não é louvor nenhum!... É uma insídia! É uma canalhice! É uma pouca vergonha! Como sabe este asno que o artigo é de Fulano, e que não é de Cicrano, ou de Beltrano... ou "meu"?! ${ }^{26}$

Assim foi o diretor-proprietário de $O$ Jornal do Porto que revelou para a literatura portuguesa Júlio Dinis, pseudônimo do médico Joaquim Guilherme Gomes Coelho, que aí publicou As pupilas do Sr. Reitor, A morgadinha dos canaviais e Uma família inglesa; assim foi o "honrado" Cruz Coutinho que Ramalho Ortigão estampou e imprimiu nesta bem-humorada crônica de saudades, neste memorável necrológio, repassado de lembranças e reminiscências, sempre mais espirituoso do que melancólico.

Ramalho já havia completado os trinta anos e ainda permanecia no Porto, lecionando francês no Colégio da Lapa e publicando folhetins na folha de Cruz Coutinho, além de artigos esparsos por outros periódicos, como, por exemplo, a Gazeta Literária do Porto, de Camilo Castelo Branco. Alguns destes artigos esparsos constam do volume Folhas soltas (1865-1915), reunião de material disperso em almanaques, revistas, jornais, álbuns de família, livros de visitantes e outros, em sua grande maioria sem outro valor que não seja 0 documental.

Já os folhetins publicados em $O$ Jornal do Porto foram, mais tarde, submetidos a uma seleção e o que dela resultou recolhido e publicado em dois tomos com títulos distintos: Crônicas Portuenses e Primeiras Prosas.

Quem atenciosamente reparar no índice destes dois livros terá a impressão de que os títulos estão inadvertidamente trocados, uma vez que, é nas Crônicas portuenses que realmente se encontra reunido o grosso das primeiras prosas de Ramalho Ortigão. Esta hipótese fica perfeitamente caracterizada na primeira destas prosas - datada de 28 de março de 1859 um texto que não é mais que uma espécie de carta de apresentação e de exposição de motivos que levaram o folhetinista a aceitar uma "nesga de colaboração" 27 nas páginas do jornal. Parece não haver dúvida de ter sido esta a primeira crônica publicada por Ramalho Ortigão em $O$ jornal do Porto,

\footnotetext{
${ }^{26}$ Ibidem, p. 70.

${ }^{27}$ Ramalho Ortigão, Crônicas portuesenses, p. 15.
} 
ocasião em que, aproveitando a oportunidade, expõe os princípios básicos que deveriam ser observados no desempenho de sua função.

Como algumas pessoas fidedignas me asseveram que não está ainda assaz líquida a diferença que existe entre um folhetim e um solilóquio de soalheiro, ficando assim indefinida a missão do folhetinista, declaro, outrossim, que nunca se discutirão aqui os mesmos negócios pessoais, e muito menos os das pessoas do meu conhecimento. $^{28}$

Estas Crônicas portuenses estão basicamente divididas em dois grandes tópicos: a "Revista do Porto", que reúne folhetins publicados no ano de 1859 e as "Cartas portuenses", que saíram entre os anos de 1862 e 1863.

Já pelo título do primeiro tópico se pode notar que o assunto predominante neste livro é o movimento teatral na cidade do Porto. São análises e comentários dos dramas e das comédias, das óperas e das tragédias apresentadas nos palcos dos teatros Baquet e São João, teatros e palcos em que, com pesar, Ramalho lamenta a falta de um foyer (é lástima que nem a palavra tenhamos cá) ${ }^{29}$, como os existentes nos principais palcos da Europa. É no foyer que, ao convívio de jornalistas, músicos, pintores, homens de letras e da política, a proteção à arte medra, o estímulo se desenvolve e o gosto se educa, como ele gostaria.

E assim, salvo uma ou outra abordagem diferente, o que realmente faz as Crônicas portuenses é a revista dos teatros: estréias, benefícios, apresentações, desempenhos, entre outras programações.

Não há como ler este livro sem levar em conta o caráter livre e solto dos textos, nos quais Ramalho se mostra sem compromisso ou pretensão maior do que simplesmente divertir suas leitoras a quem constantemente convoca e traz à baila. São as consagradas e habituais fórmulas de sugerir aproximação e familiaridade, como apóstrofes e recorrências às "minhas leitoras", categoria especial de mulheres, que Cruz Coutinho, proprietário do

\footnotetext{
${ }^{28}$ Ibidem, pp. 14, 15. Fica muito claro o sentido deste texto quando se entende o vocábulo "soalheiro" como agrupamento de pessoas ociosas e maledicentes, que expostas ao sol, discutem a vida alheia.

${ }^{29}$ Ibidem, p. 155.
} 
jornal, um dia lhe fez acreditar que, só pelo simples e casual fato de lerem a folha, tornavam-se aos olhos de ambos "adoráveis criaturas"30.

Ditos graciosos, ironias, chistes e brincadeiras, tudo em nome do entretenimento, dão muitas vezes ao leitor destas páginas a impressão de que o autor se sentia desempenhando funções subalternas, muito aquém de suas potencialidades.

Já não se dá o mesmo quando se lêem as Primeiras Prosas, o outro tomo que resultou da recolha dos folhetins de $O$ Jornal do Porto. Conquanto certos textos ainda transpirem uns ares de entretenimento, o tom geral é outro, conduzido agora pela seriedade e circunspeção, a quadrar-se melhor com intenções de convencimento. É o artigo de fundo tomando o lugar do folhetim literário, tema que, aliás, o autor aborda no preâmbulo do texto intitulado "Viagem de experiência ao viaduto de Esgueira e à ponte do Pano".

Eu estou cansado de me ouvir acoimar de fútil e de amulherengado em pontos de literatura.

- Por que não escreve você artigos sérios? - perguntamme às vezes as pessoas interessadas nos meus aumentos - Sempre folhetim, sempre folhetim! Escreva política, se quer ver uma vez destampado o manancial da glória e da pública consideração. ${ }^{31}$

Datado de 20 de julho de 1863, esse texto das Primeiras prosas, dado seu conteúdo e a forma como foi redigido, chega mesmo a suscitar dúvida quanto à sua classificação: folhetim literário ou artigo de fundo?

Se nas Crônicas portuenses o que prevalecia como tema era o teatro, nas Primeiras prosas o que vai prevalecer é a literatura. Mas é curioso notar que temas secundários e muito pouco explorados destes dois livros que reúnem os trabalhos da juventude de Ramalho Ortigão irão acabar se tornando dominantes na obra da maturidade. É tipicamente o caso do texto intitulado "Belas-artes", das Crônicas portuenses, que recebeu o subtítulo de "Esboço de análise aos trabalhos dos candidatos à cadeira de escultura vaga na Academia

\footnotetext{
${ }^{30}$ Ibidem, p. 102.

${ }^{31}$ Ramalho Ortigão, Primeiras prosas, p. 159.
} 
Portuense das Belas-artes". Três são os candidatos e três as esculturas que cada qual deveria apresentar à comissão julgadora: representação de Caim matando Abel, representação de uma mulher no banho e estudos do nu artístico.

Louvores a Deus, que aí temos finalmente nesta utilitária terra do Porto não menos de nove esculturas, de uma só vez, no Ateneu de São Lázaro, a convidarem os olhos ávidos e a cevarem a crítica emagrecida pelos mais longos jejuns. ${ }^{32}$

É a grande oportunidade que tem Ramalho de exercer esta veia crítica que fará dele um dos mais fecundos e representativos estudiosos, em sua época, das artes plásticas em Portugal, com o devido destaque aos estudos realizados em alguns monumentos arquitetônicos que visitou, denunciando o estado de abandono em que se achavam. Tudo fez para chamar a atenção do povo e das autoridades civis a quem competia zelar pela preservação deste patrimônio artístico. Só muito tempo depois de suas denúncias o governo português veio a tomar as devidas providências.

Apontou-se no parágrafo anterior especialmente seu interesse pelos monumentos arquitetônicos, mas inúmeros são também seus trabalhos sobre a pintura, a escultura e a cerâmica portuguesa. E desta faceta de sua obra a Gazeta de Notícias dá uma série de testemunhos.

Outro destes temas secundários, que já aparecem em as Primeiras prosas, e que terão importante papel em sua obra da maturidade são os relatos de viagens. Servem de exemplos a "Viagem de experiência ao viaduto de Esgueira e à ponte do Pano", escrito em 1863; "Os meus amigos de Peniche" e "Do Porto a Aveiro", ambos escritos no ano seguinte. O primeiro destes relatos, do qual se apontou anteriormente um aspecto do preâmbulo, é basicamente a reportagem da solenidade comemorativa da inauguração do viaduto e da ponte da estrada de ferro do Porto a Aveiro, comemoração que deu direito a merenda, brindes e saudações, agradavelmente compartilhados por jornalistas, autoridades e funcionários graduados e, tudo, servido à sombra de um bosque de pinhais; o segundo é muito mais a narração do convívio com

\footnotetext{
${ }^{32}$ Idem, Crônicas portuenses, p. 255.
} 
alguns habitantes da cidade de Peniche do que propriamente a descrição da viagem, que é a essência do terceiro relato: "Do Porto a Aveiro". Aqui, sim, aqui a viagem principia a ser descrita desde a Praça Nova, no centro da cidade do Porto até a estação das Devesas, do outro lado do rio Douro, trajeto percorrido por um char à bancs, uma espécie de carruagem de seis lugares, coberta com tejadilho.

Ramalho enumera, localiza e descreve minuciosamente seus companheiros de viagem. Com olhos de investigador, atento a detalhes, tudo observa e comenta, desde o "chapéu alto" ou de "casimira alvadia com uns bordos de meia polegada" até a "bota de bico estreitinho, quadrado, de quinas percucientes e do comprimento de dois dedos adiante da ponta do pé"33.

Da estação das Devesas segue em caminho de ferro até Aveiro, praticamente a mesma viagem que já havia, há quase um ano atrás, realizado como repórter nas inaugurações das pontes de Esgueira e do Pano. Mas, se daquela vez ele representava oficialmente a imprensa e viajava a convite da Companhia, desta vez não, desta vez ele seguia como um viajante qualquer, anonimamente e sem privilégios.

Naqueles tempos as vias férreas principiavam a ser abertas em Portugal e muita gente viajava pelo simples prazer da novidade. Ramalho, como bom observador, capta a atmosfera da época, o reboliço das estações, o corre-corre das pessoas, o farfalhar das saias roçagantes, o esfuziar de risos soltos, radiantes, a prenunciar a alegria corrente nos wagons.

Sem dúvida alguma, é a literatura de viagem um dos temas mais representativos de toda a colaboração de Ramalho Ortigão para a Gazeta de Notícias. Haja vista, por exemplo, A Holanda, que é pouca coisa mais do que as impressões de uma viagem de aproximadamente três meses - ao que tudo indica, financiada pela própria Gazeta - que ele realizou por aquele país. E por justa razão foi ela quem, com exclusividade, primeiramente publicou esta obra em folhetins.

\footnotetext{
${ }^{33}$ Idem, Primeiras prosas, p. 234.
} 
No entanto, os relatos de viagens eram temas secundários nas Primeiras prosas. Como já foi assinalado, o que aí prevalecia como assunto principal era a literatura, tratada em nada menos de dez entre os dezesseis temas constantes do livro. É justamente nesta obra que se tem, ao lado da saudação a $O$ gênio do cristianismo, de Chateaubriand, traduzida por Camilo Castelo Branco e revisada por Augusto Soromenho, que "é em sua máxima parte perfeita e cabal”34, sendo só para lamentar que na parte final do livro o desvelo do tradutor, diz Ramalho, não se tenha mostrado à altura "da alta reputação de vigoroso e castigado estilista" ${ }^{35}$, uma pequena polêmica literária, uma espécie de preâmbulo da grande polêmica que teria curso pouco tempo depois e que ficou conhecida, historicamente, como a Questão Coimbrã. É uma pequena polêmica, não resta dúvida, mas conta com a participação de eminentes personagens da grande polêmica, especialmente o poeta Antônio Feliciano de Castilho que com a sua "Conversação preambular" havia apresentado o poema $D$. Jaime, de Tomás Ribeiro.

Pois bem, Ramalho, após aguardar ansiosamente ${ }^{36}$ a publicação do livro, leu o poema e a "Conversação preambular". Leu uma coisa e outra, não gostou de nenhuma delas e teve a audácia de manifestar seu desagrado em um folhetim de $O$ Jornal do Porto.

Já se disse aqui que os artigos publicados na folha de Cruz Coutinho eram, em sua maioria, anônimos. Acontece que, desta vez, Ramalho, pressentindo os desdobramentos que sua crítica, indubitavelmente, provocaria, fomenta ainda mais as paixões, concluindo desta forma provocativa seu folhetim:

De muito tempo para cá não são assinados os meus desvaliosos escritos publicados nesta folha. Haverá talvez no presente alguma coisa ofensiva a uma reputação literária; acudo pois a cercearlhe a ação nociva subscrevendo este com o meu nome. ${ }^{37}$

\footnotetext{
${ }^{34}$ Ibidem, p. 31.

${ }^{35}$ Ibidem, p. 31.

36 "Se há muito tempo houve livro suspirado pela ociosa crítica portuguesa e apetecido de alma pela impaciência pública, foi este sem questão alguma.” ( Ramalho Ortigão, Promeiras prosas, p. 49)

${ }^{37}$ Ibidem, p. 68.
} 
Mexer com os barões literários da corte do rei D. Luís era o mesmo que "cutucar com taquara-poca casa de marimbondo tampa-goela."

Logo saltaram à liça e saíram a público, de pena em punho, três destemidos e fiéis templários da igrejinha literária das reputações firmadas, cujo papa acontecia de ser justamente o autor da "Conversação preambular". Eram eles: Leonel de Sampaio, folhetinista e bibliógrafo do Diário Mercantil; Pinheiro Chagas ${ }^{38}$, redator da Revolução de Setembro e José Feliciano de Castilho, irmão de Antônio, que inseriu nas folhas do Constitucional, do Rio de Janeiro, uma série de nove artigos contestando o juízo crítico do folhetinista portuense.

A verdade é que não deixavam de ter razão os seus contestadores. Ramalho era amigo da polêmica e, a par de ser provocativa, a sua crítica era também superficial, injusta e passadista.

Quem dela gostou foi outro polemista inveterado, Camilo Castelo Branco, que lhe confessou em carta ter desistido da leitura do poema de Tomás Ribeiro, no sexto canto, por referências feitas a usos e costumes surgidos tempos depois das ações que descrevem as desventuras do fidalgo português, insinuando mesmo encontrar-se o melhor de D. Jaime em Zorrila (José Zorrila Moral), poeta e dramaturgo espanhol do século XIX que reviveu em suas obras algumas das antigas tradições da Espanha. Ao final da carta confidencia Camilo a Ramalho: "Não cogite mais no que pensaram os outros acerca do $D$. Jaime. Basta dizer-Ihe que o seu folhetim agradou a todos"39.

Uma informação merecedora de registro, revelada de passagem e ao acaso na carta a José Feliciano de Castilho, é a menção a uma

\footnotetext{
38 A resposta de Ramalho a Pinheiro Chagas foi publicada em 11 de setembro de 1862 e desde os primeiros parágrafos deixa transparecer os propósitos que a animaria.

"Quis V. S a refutar a minha opinião acerca do D. Jaime, e entendeu que era bem tirar a gravata, arregaçar as mangas à sua dialética, e mostrar-me uns braços musculosos e possantes.

Poderia isto parecer mal a qualquer outro; a mim pareceu-me simplesmente que V. $S^{a}$. era um homem ordinário.

Escrevo-lhe pois esta sem ódio nem má vontade. Que culpa tem V. S ${ }^{\mathrm{a}}$. em que uma casaca o flagele e uma gravata o suplicie?!...” ( Ramalho Ortigão, Primeiras prosas, p. 85)

Vê-se, por aí, o quanto Ramalho havia antecipado a Eça de Queirós as pendências com Pinheiro Chagas.

${ }^{39}$ Novas cartas inéditas de Eça de Queirós e outros a Ramalho Ortigão, p. 173.
} 
correspondência anônima enviada do Porto ao Correio Mercantif ${ }^{40}$, do Rio de Janeiro. Ao que se pôde deduzir, José Feliciano de Castilho, em um dos artigos do Constitucional, faz transparecer, tornando público, o nome do correspondente do Correio Mercantil (no caso Ramalho Ortigão) que, pela forma como reagiu, parece que preferia mantê-lo no anonimato, como vinha fazendo.

Também peço encarecidamente a $V \cdot E^{a}$ que não continue a confundir Ramalho Ortigão, folhetinista de $O$ Jornal do Porto, com o correspondente anônimo do Correio Mercantil do Rio de janeiro. $\mathrm{O}$ folhetinista aqui o tem $\mathrm{V}$. $\mathrm{Ex}^{\mathrm{a}}$. e há de tê-lo sempre para responder pelo que escreve. Com esta distinção me faz V. Ex $x^{a}$. um particular serviço, servindo-se simultaneamente a si de cavalheirismo e delicadeza que o correspondente do jornal do Rio tem fundamento para negar-lhe. E bom fundamento me parece, pois que V. $\mathrm{Ex}^{\mathrm{a}}$. lhe está atribuindo um nome (verdadeiro ou falso) que ele por considerações que não são do domínio de ninguém entendeu calar. ${ }^{41}$

Outras informações a respeito deste caso podem ser colhidas na obra que Júlio de Oliveira publicou a respeito do fraternal convívio entre Ramalho Ortigão e Eça de Queirós, rememorando e esclarecendo fatos de ordem literária e jornalística da vida destes dois escritores. Neste trabalho o jornalista portuense reuniu uma série de cartas enviadas por Ramalho a Fernandes Reis, seu antigo companheiro de redação em $O$ Jornal do Porto. (Fernandes Reis é aquele mesmo que, designado por Cruz Coutinho, acompanhou o padre Mendes, já doente, até a ilha da Madeira). As informações contidas nestas cartas permitem deduzir e considerar ter sido ele a pessoa encarregada de organizar e enviar, do Porto, para o Correio Mercantil, do Rio de Janeiro, o pacote em que iam juntas a parte noticiosa que acompanhava a correspondência e o folhetim anônimo que era escrito por Ramalho. Como infelizmente não são datadas estas cartas recolhidas por Júlio de Oliveira, resta apenas como recurso para se conhecer o período desta colaboração a aproximação de datas e o cruzamento de informações. Sabe-se,

\footnotetext{
${ }^{40}$ Registre-se, como lembrança, ter sido neste jornal, mais precisamente em seu suplemento denominado "A Pacotilha", que pela primeira vez se imprimiram as Memórias de um sargento de milícias.

${ }^{41}$ Ramalho Ortigão, Primeiras prosas, p. 122.
} 
por exemplo, que o Correio Mercantil, deixou de circular em fins de 1868, fato que Ramalho lamenta em carta ao amigo Fernandes, e seria para se lamentar mesmo, afinal de contas era uma fonte que secava para ambos. Como a carta a José Feliciano de Castilho, em que é feita alusão à correspondência, saiu em O Jornal do Porto em fins de 1862, deduz-se então que, durante um período de pelo menos seis anos (1862-1868), Ramalho Ortigão colaborou anonimamente é verdade - no Correio Mercantil, do Rio de Janeiro.

$O$ justo conhecimento da natureza e do teor desta correspondência, bem como a razão pela qual preferiu Ramalho o anonimato nestes artigos enviados ao Brasil, ele que jamais poderia ser considerado um modelo de modéstia e despretensão, só mesmo uma consulta aprofundada às páginas do Correio Mercantil poderia revelar, tarefa que extrapola o âmbito desta pesquisa, restrita às colaborações, que já não são poucas, enviadas à Gazeta de Notícias.

Uma nova revista brasileira

Ainda em meio àqueles dez folhetins sobre literatura, recolhidos nestas Primeiras prosas, merece comentário o que foi publicado no dia 23 de outubro de 1862, com o título de "Um periódico brasileiro e um escritor portuense". Nele Ramalho saúda o aparecimento de uma revista editada na corte do Rio de Janeiro pelo amigo e conterrâneo Faustino Xavier de Novais, que havia deixado saudades na elite boêmia-intelectual da velha cidade do Porto, desde o dia de sua emigração.

Eu conheci-o poeta, conheci-o simplesmente poeta; tinha uma alma cândida e nobilíssima, e lograva o dúplice dote da sensibilidade infantil e da firmeza inabalável de um varão experimentado. ${ }^{42}$

\footnotetext{
${ }^{42}$ Ibidem, p. 107.
} 
Faustino que havia chegado ao Brasil em meados de 1858 era mais um minhoto, entre tantos, a procurar no Rio de Janeiro condições propícias de honestamente fazer fortuna. Com esse intuito, estabeleceu-se na Rua Direita para o comércio de papel, livros, objetos de escritório, charutos, rapé, chá-mate e outros artigos do gênero, sem contudo pôr de parte o sonho de conjugar negócio e arte, comércio e literatura. Assim é que, por graça, recreação e desenfado de tão burguesa atividade, ia produzindo, entre o cerrar e o descerrar das portas de sua loja, folhetins que levava para os jornais cariocas, como é tipicamente o caso das "Cartas de um roceiro", que o mesmo Correio Mercantil, há pouco citado, estampou em suas páginas, sob o pseudônimo de Bernardo Júnior.

Mas, infelizmente, o poeta e o comerciante não foram capazes de manter um relacionamento profissional eficiente, seguro e duradouro e não demorou muito para que os credores lhe batessem à porta com uma solicitação de assentimento e uma proposta de concordata. Faustino ainda relutou, mas como aquele barco já vinha, há tempos, desgovernado achou melhor dar a vela a outros ventos, o leme a outros rumos e se estabelecer, desta feita, na praça do Rio de Janeiro, como editor.

Sonhou assim com uma publicação em formato de revista, de periodicidade quinzenal e cunho literário que contasse entre seus colaboradores nomes consagrados como os de Camilo Castelo Branco e Gonçalves Dias, por um lado e por outro, novatos, que embora revelassem talento, careciam ainda de nomeada, como era o caso de Bernardo Guimarães e Machado de Assis $^{43}$. E foi com esta massa pura que se moldou a revista $O$ Futuro, lançada em 15 de setembro de 1862, sendo saudada por Ramalho Ortigão no dia 23 do mês seguinte em folhetim de $O$ Jornal do Porto.

Do primeiro número, efetivamente, participaram Machado de Assis, amigo novo do editor e Camilo Castelo Branco, velho amigo de Faustino dos tempos em que ambos - moços e boêmios - costumavam freqüentar as noitadas da cidade invicta, sempre à cata de aventuras que Ramalho registrou

\footnotetext{
${ }^{43}$ Eis os nomes mais conhecidos de colaboradores da revista citados por Ramalho: Alexandre Herculano, Antônio Feliciano de Castilho, João Cardoso de Menezes, Joaquim Manuel de Macedo, Joaquim Pinto de Campos, José de Alencar, José Feliciano de Castilho, José Maria Latino Coelho, José da Silva Mendes Leal, Júlio César Machado, Luís Augusto Rebelo da Silva eQuintino Bocaiúva.
} 
em vários passos de sua obra. Para este número de estréia, Camilo Castelo Branco enviou um artigo especial intitulado "O melhor amigo de Camões".

O periódico de Faustino sobreviveu até julho de 1863 e nele Machado de Assis teve participação ativa, publicando um conjunto de dezesseis crônicas, todas recolhidas em 1937 no primeiro volume das Crônicas (1859-1863), um dos tomos das Obras Completas de Machado de Assis, da editora Jackson.

Merece atenção e desperta curiosidade a primeira destas crônicas, que apresenta em seu preâmbulo uma conversa de obreiro com sua ferramenta, consubstanciada nos conselhos do escritor à sua pena. É assim uma espécie de representação alegórica do programa e das normas que deveriam conduzir e nortear a atuação do cronista. Eis os termos desta alegoria:

Antes de começarmos o nosso trabalho, ouve, amiga minha, alguns conselhos de quem te preza e não te quer ver enxovalhada... Não te envolvas em polêmicas de nenhum gênero, nem políticas, nem literárias, nem quaisquer outras; de outro modo verá que passas de honrada a desonesta, de modesta a pretensiosa, e em um abrir e fechar de olhos perdes o que tinhas e o que eu te fiz ganhar. $\mathrm{O}$ pugilato das idéias é muito pior que o das ruas; tu és franzina, retrai-te e fecha-te no círculo dos teus deveres, quando couber a tua vez de escrever crônicas. Sê entusiasta para o gênio, cordial para o talento, desdenhosa para a nulidade, justiceira sempre, tudo isso com aquelas meias-tintas tão necessárias aos melhores efeitos da pintura. Comenta os fatos com reserva, louva ou censura, como te ditar a consciência, sem cair na exageração dos extremos. E assim viverás honrada e feliz. $^{44}$

E se esse procedimento não garantia uma vida plena de euforias, assegurava, ao menos, uma existência escassa de aborrecimentos. Ampliando-se o sentido desta alegoria machadiana quase se poderia dizer que este texto não passa de um autêntico solilóquio do escritor. Configura-se aí o

\footnotetext{
${ }^{44}$ Machado de Assis, Crônicas, v. I, p. 300.
} 
gosto pela dissimulação (meias-tintas), pelo comedimento (meios-termos), assinalando uma constituição moral reservada, avessa ao embate das idéias.

O texto semelha mesmo o traçado pelo qual procurou nortear seu caminho na vida, a linha de conduta da qual só se afastou em raríssimas oportunidades.

Além desta introdução em forma de programa, a crônica de Machado de Assis apresentava ainda dois comentários: um ao poema $D$. Jaime, de Tomás Ribeiro, que acabava de chegar pelo último vapor e outro ao romance histórico de José de Alencar, As minas de prata, de que a "Biblioteca Brasileira“ - uma publicação de Quintino Bocaiúva - dava à estampa o primeiro volume. Havia também notícias de teatro e o registro de uma despedida ao pianista português Artur Napoleão, que seguia para Buenos Aires, de onde regressaria à Europa ${ }^{45}$.

De todos estes tópicos o que realmente interessa e vem ao caso são os comentários de Machado de Assis ao poema D. Jaime. Ao mesmo tempo que é interessante é desapontador constatar o quanto o cronista foi fiel à sua pena. Sua crítica não vai além de algumas considerações gerais a respeito do trabalho de Tomás Ribeiro, permanecendo em uma superficialidade cômoda, a repetir louvores lidos ou ouvidos nas rodas literárias, sem qualquer alusão à "Conversação preambular", tema principal da crítica de Ramalho Ortigão, publicada dois meses antes em $O$ Jornal do Porto e que seguramente Machado de Assis conhecia, assim como também devia conhecer toda a polêmica por ela suscitada. (Tenha-se na lembrança o jornal Constitucional, do Rio de Janeiro, e a série de nove artigos nele publicados por José Feliciano de Castilho, contestando a crítica de Ramalho).

"Não te envolvas em polêmicas de nenhum gênero", aconselhava o cronista à sua pena, como quem lembrasse a ela que "cautela e caldo de galinha”... São cuidados que caracterizam um temperamento tímido e retraído, muito diverso do temperamento expansivo e exuberante de Ramalho Ortigão, sempre disposto à luta, pronto para o "pugilato das idéias", que

\footnotetext{
${ }^{45}$ Quando quatro anos depois Artur Napoleão retornou ao Brasil, coincidentemente, chegou no mesmo vapor que trazia a irmã de Faustino, Carolina Xavier de Novais, futura esposa de Machado de Assis, seguramente o escritor que mais colaborou na revista de seu irmão.
} 
confessadamente tanto prezava e distinguia: "adoro a polêmica e ainda tenho o meu dente de outro tempo para estes bocados bons" ${ }^{\prime 46}$, confessou ele certa vez.

Esse "outro tempo" era aqueles tempos da cidade do Porto, já que se achava em Lisboa quando isso disse ao amigo Fernandes Reis. Eram os tempos em que freqüentemente as controvérsias jornalísticas evoluíam para verdadeiras rixas literárias que acabavam, na melhor das hipóteses, em grossa pancadaria. Tempos em que a mocidade portuense ilustrada, com vocação literária e pretensões socialistas em seu vago desprezo pelo capital, contrapunha-se aos homens graves e ordeiros, parcimoniosos e materialistas, burgueses, enfim, que viviam de sonhar com títulos, comendas e brasões. Tempos em que era comum Ramalho cruzar pelos cafés ou pelas ruas da cidade com poetas, prosadores e jornalistas: Arnaldo Gama e Evaristo Basto, Camilo Castelo Branco e Júlio Dinis, Alexandre Braga e o próprio Faustino Xavier de Novais.

Em uma das últimas vezes que Ramalho, então um estreante no meio jornalístico, com ele esteve, ele que já tinha um nome feito e era uma figura respeitada no meio literário do Porto, quer como poeta, quer como folhetinista, sabendo de suas intenções de deixar Portugal, curioso, quis saber para onde Faustino pretendia se aventurar:

- Para o Brasil, para a terra do trabalho e do ouro.

- E quando voltas?

- É provável que nunca. ${ }^{47}$

Cruel vaticínio! Faustino, realmente, jamais retornou à sua cidade, ficando mesmo pelo Rio de Janeiro, onde, por fim, viveu de favores de uma senhora da sociedade carioca e morreu em precárias condições.

Mas a chegada do vapor Tamar com o poeta que tanto havia divertido os portuenses com suas composições satíricas representava, para os

\footnotetext{
${ }^{46}$ Júlio de Oliveira, Ramalho Ortigão e Eça de Queirós, p. 68.

${ }^{47}$ Ramalho Ortigão, Primeiras prosas, p. 110.
} 
cariocas, renovadas esperanças de riso ${ }^{48}$. Eram bem conhecidos os versos que compunha como quem cosia carapuças para a cabeça dos barões iletrados. Dizia Camilo que Faustino as talhava e vestia até as orelhas das vítimas, mas só até as orelhas, pois que essas nem mesmo ele era "capaz de encarapuçar" ${ }^{\prime 9}$.

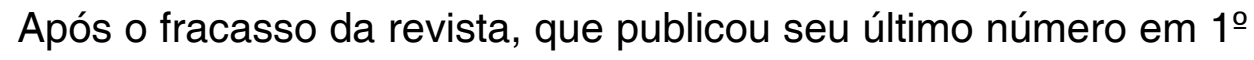
de julho de 1863, Faustino passou a escrever para o Correio Mercantil, publicando aí uma série de crônicas semanais com o título de "Cartas de um roceiro", material recolhido e publicado em volume, em 1867, pela Tipografia Perseverança, casa impressora carioca com sede à Rua do Hospício.

Por ironia do destino, dois anos após a publicação, Faustino faleceu em lamentável estado de depressão moral e intelectual completamente privado da razão. Morreu sem mesmo ter tido tempo de assistir ao casamento da irmã, Carolina, com o amigo Joaquim Maria, ocorrida três meses depois, uma união que, é bom que se lembre, era ele o único da família a fazer gosto.

\footnotetext{
48 Nesta expectativa de riso pronto se punha até mesmo Casimiro de Abreu, que saudava em redondilhas maiores a chegada de Faustino Xavier de Novais:

"Bem vindo sejas, poeta,

A estas praias brasileiras!

Na pátria das bananeiras

As glórias não são demais:

Bem-vindo o filho do Douro!

À terra das harmonias,

Que tem Magalhães e Dias,

Bem pode saudar Novais.

Vieste a tempo, poeta,

Trazer-nos o sal da graça,

Pois c'os terrores da praça

Andava a gente a fugir:

Agora calmando o medo,

E ao bom humor dando largas

A comprimir as ilhargas

Agora vão todos rir."

(Poesias completas de Casimiro de Abreu, p. 168)

${ }^{49}$ Magalhães Bastos, Figuras literárias do Porto, p. 23.
} 


\section{2 - Nos tempos de Lisboa}

Não há como garantir terem sido os comentários publicados em $O$ Jornal do Porto, sob a rubrica de Ramalho Ortigão, a uma obra mística, ou pretensamente mística, do convertido barão de Castelo e Paiva - sócio efetivo da Academia Real das Ciências de Lisboa - a chave-mestra que lhe possibilitou abrir as portas desta Academia. A verdade, porém, é que pouco tempo depois de publicados os comentários - por sinal que nada lisonjeiros - o folhetinista do jornal de Cruz Coutinho era nomeado oficial de secretaria daquela instituição acadêmica.

Antes, porém, de se transferir definitivamente para Lisboa, Ramalho Ortigão passa uma temporada em Paris e traz na mala, ao regresso, em meio a gravatas, luvas e camisas, o primeiro de seus livros de viagem: Em Paris.

Hospedando-se em um apartamento mobiliado da Rua Mazagran - la maison meublée, como presunçosamente chama o quarto de dormir conjugado com a sala de receber - Ramalho demorou nesta cidade uns três meses, lá permanecendo de fins de 1867 até começos do ano seguinte, mesmo período em que apareceram no Diário de Notícias, de Lisboa e em 0 Jornal do Porto, os folhetins com as suas impressões de viagem ${ }^{50}$. São estas impressões, antecedidas de um prólogo do autor, que constituem este livro simplesmente intitulado Em Paris. Sua publicação deu-se no mesmo ano da transferência de Ramalho para Lisboa: 1868.

No prólogo que o autor redigiu a bordo do navio que o levava de Lisboa até Paris, faz uma série de considerações a respeito do que representava a viagem em seu temperamento de artista. Considera ele, por exemplo, que viajar era o mesmo que fugir a um cotidiano opressivo e infecundo para encontrar, em outra realidade, a liberdade criadora.

\footnotetext{
${ }^{50}$ Quando, dez anos depois, realizou-se a Exposição Universal de Paris de 1878, Ramalho passou outra temporada nesta cidade, só que desta vez seus folhetins apareceram na Gazeta de Notícias, do Rio de Janeiro. A recolha deste material resultou no livro Notas de viagem.
} 
Mais de trinta anos depois destas considerações, é basicamente essa mesma coisa o que diz em carta à esposa, que reclamava a sua ausência: "preciso para renovar a minha cabeça da solidão contemplativa das viagens" ${ }^{51}$.

$\mathrm{E}$, como ele mesmo assegura, ao cabo de tudo há o prazer do retorno, o regresso à pátria e ao lar representando uma espécie de renovação que é consubstanciada no afago aos filhos, no beijo à esposa, na sensação sempre confortável de se achar novamente instalado em seus próprios domínios.

É ainda neste prólogo que o autor se propõe a "singelamente conversar" ${ }^{\prime 2}$ com os leitores, sem compromisso ou pretensão de se tornar disfarçado e maçador ("embiocado e sorna", como ele diz) - o que rigorosamente o livro não desmente, como também não desmente, nem o autor esconde, o prazer e o gosto que lhe provocava o contato direto com a cidade de Paris e com a sociedade francesa do Segundo Império, período em que a imperatriz Eugênia, com sua elegância e bom gosto, era um símbolo a irradiarse por toda a Europa. É bem verdade que já havia quem respirasse um ar de declínio no regime autoritário de Napoleão III, que, a cada passo, se via obrigado a fazer novas concessões à ala oposicionista. Neste ano de 1867, por exemplo, concedeu aos deputados o direito de discutir os atos de seu governo. Isto, porém, não foi motivo de preocupação para Ramalho. O que deveras o motivava e atraía eram os aspectos mundanos daquela cidade que a corte de Napoleão III, pelo gosto do luxo e da ostentação, havia transformado em um verdadeiro carrossel de sonhos e ilusões.

Que se haveria de esperar de um moço portuense, professor de francês no colégio do pai e que, para complemento do orçamento familiar, escrevia folhetins para uma gazeta provinciana?

Bastaria uma pequena passagem de olhos pelos títulos do material recolhido neste livro, Em Paris, para se perceber quais eram

\footnotetext{
${ }^{51}$ Ramalho Ortigão, Cartas a Emília, p. 21.

${ }^{52}$ Idem, Em Paris, p. 7.
} 
exatamente os seus interesses: "Jantares e jantantes", "A parisiense", "O petit Crevé" são alguns exemplos.

Como tudo isto combinava bem com o feitio de Ramalho! Como tudo combinava muito bem com seu gosto apurado, seu requinte e elegância, o bom-tom e seu espírito afrancesado!

Mas, é claro que não poderia deixar de visitar Ferdinand Denis, por tudo quanto este francês representava para a cultura portuguesa e brasileira, particularmente para a literatura dos dois países. O autor do Resumo da história literária de Portugal e da história literária do Brasil, publicado em 1826, residia em uma pequena casa ao lado da Biblioteca Santa Genoveva, da qual havia sido conservador, e desde 1865 era encarregado de sua administração. Ferdinand Denis ${ }^{53}$ falou dos escritores portugueses e brasileiros que conhecia, especialmente de Felinto Elísio, amigo pessoal de seu pai, assíduo freqüentador de sua casa, e de Gonçalves Dias, de quem revelou guardar ainda na memória vivas lembranças de sua passagem por Paris, pouco antes do embarque e do trágico naufrágio nas costas do Maranhão.

Foi com lágrimas na voz e com a maior tristeza no semblante que Ferdinand Denis se referiu aos últimos dias que Gonçalves Dias, o chorado poeta brasileiro, viveu em Paris, profundamente minado pela enfermidade que depois lhe deu por túmulo o oceano. ${ }^{54}$

Dizia ele que o poeta, para espairecer as mágoas, fumava constantemente e falava da morte e da doença que lhe consumia os pulmões "com uma glacial indiferença que compungia profundamente quantos 0 conheciam e amavam" 55 .

Só após uma entrevista de duas horas, Ramalho deixou o escritor que tanto admirava e com quem depois passou a se corresponder. Em sua

\footnotetext{
${ }^{53}$ Ferdinand Denis, que viajou pelo Brasil em princípios do século XIX, é autor, em colaboração com Hipólito Taunay, de uma obra em seis volumes, intitulada $O$ Brasil, ou história, hábitos, usos e costumes desse reino.

${ }^{54}$ Ramalho Ortigão, Em Paris, p. 80.

${ }^{55}$ Ibidem, p. 80.
} 
opinião, Ferdinand Denis era responsável, até aquele momento, pela "mais completa", senão "única história literária de Portugal”"56.

Eram vizinhos de Ramalho, à rua Mazagran, dois escritores que, na época, eram muito respeitados nas letras francesas: um deles era Lambert Thiboust, autor de numerosas peças representadas em quase todos os teatros parisienses, das quais Ramalho assiste, resumindo a trama para os leitores de seus folhetins, Je dine chez ma mère, comédia em um ato que considera talvez um pouco exageradamente - "uma verdadeira obra-prima" 57 ; o outro era Albert Wolff, o alemão que ao se fazer parisiense tornou-se um dos mais lidos e estimados cronistas da cidade.

Tempos atrás, este alemão havia sido secretário de Alexandre Dumas, pai, e era agora um dos primeiros redatores do Le Figaro. Ramalho, que o tinha na conta de "um dos homens mais espirituosos da França" ${ }^{58}$, teve com ele uma entrevista de mais de duas horas, relatada de passagem no capítulo "Jantares e jantantes".

"Wolff, que é um rapagão novo, alto, cheio e simpático, recebeume de braços abertos" 59 , escreve ele, vaidoso, superestimando-se aos olhos dos leitores que desejava impressionar e atrair-lhes a admiração. No fundo, artimanhas de moço pretensioso que ambicionava ir desde logo aplainando os caminhos que poderia trilhar no futuro. É lícito pensar assim, uma vez que, seja lembrado, o Diário de Notícias, sediado em Lisboa, cidade para onde seguiria, também estava publicando os seus folhetins.

Com exceção de Ferdinand Denis e Alberto Wolff, não há registro de nenhum outro encontro de relevo na agenda de Ramalho Ortigão, nesta sua viagem a Paris.

Outro assunto que vale a pena destacar, neste livro, é a sempre discutida questão da subliteratura. Aqui ela foi simbolicamente representada pela figura do escritor Ponson du Terrail, o autor daquelas intermináveis aventuras rocambolescas. Todo um capítulo é dedicado a ele, cuja obra

\footnotetext{
${ }^{56}$ Ibidem, p. 75.

${ }^{57}$ Ibidem, p. 146.

${ }^{58}$ Ibidem, p. 145.

${ }^{59}$ Ibidem, pp. 145, 146.
} 
literária, na opinião de Ramalho, corrompia o "gosto como empadão indigesto", arruinando "estômagos intelectuais" como se contivessem em sua fórmula de composição "sucos derrancados e podres" 60 .

Não se sabe ao certo se por simples pilhéria ou cabal intolerância, chega Ramalho ao extremo de pedir punição para aquilo que considerava um crime de adulteração, embora aqui se tratasse apenas de um crime de adulteração literária.

É de muito mau exemplo a impunidade nestes casos. Pune-se o homem que adultera os gêneros alimentícios, por que se não há de punir o sujeito que adultera os gêneros literários? $?^{61}$

Conquanto burlesca, a crítica serve para demonstrar que a questão da arte de consumo, especificamente, neste caso, da subliteratura, já era um tema recorrente na época.

É bem provável que a decadência literária, representada pelos folhetins de Ponson du Terrail, estivesse diretamente relacionada com a revolução na imprensa, representada pela ação de Girardin. É isto o mesmo que dizer que a popularização do jornal trazia em seu próprio bojo, tal qual um monstrengo diabólico, o veneno, "os sucos derrancados e podres", que inevitavelmente acarretariam a popularização da literatura, fazendo com que adquirissem importância e relevo aqueles escritores que fossem capazes de se ajustar ao gosto popular, atingindo com este artifício um número maior de leitores. Naturalmente esta nova imprensa ia pouco a pouco pondo de parte e deixando de lado aqueles artistas sinceros e conscienciosos que ainda acreditavam "na arte, no belo e no ideal" 62 .

Mas, se para a literatura de Ponson du Terrail só teve palavras de condenação e censura, para a parisiense, considerada o ídolo do altar que é Paris, e para os restaurantes, onde, assegurava, poder-se-ia ter a graça de jantar acompanhado em sua mesa de literatos e artistas, em um convívio

\footnotetext{
${ }^{60}$ Ibidem, p. 241.

${ }^{61}$ Ibidem, pp. 246, 247.

${ }^{62}$ Ibidem, p. 243.
} 
espirituoso que tornava o menu ainda mais refinado, reservou somente palavras de enaltecimento.

O capítulo "Jantares e jantantes" - de todos o mais desenvolvido - nada mais é que um amontoado de referências elogiosas aos restaurantes e aos pratos da cozinha francesa que neles eram servidos - lisonjas e gabações imoderadas mais próprias de espíritos louvaminheiros.

E como se não bastasse, este capítulo também serve de base para comparações e paralelos com Portugal, um procedimento comum nos livros de viagem de Ramalho Ortigão. Embora a fase mais iconoclasta de sua carreira jornalística ainda estivesse por vir com a edição de As farpas, ele, que naquele momento se achava inserido em uma sociedade que considerava superior e que, sobretudo, o deslumbrava e atraía, não iria ser condescendente com a realidade de seu país. Veja-se, por exemplo, o que ele fala da cozinha, da dança e da música portuguesas:

No fim de contas a cozinha portuguesa, tão decantada por bons engenhos, que eu muito venero, é como a dança portuguesa e a música portuguesa: três coisas que estão por se criar. ${ }^{63}$

Evidentemente que as coisas não se passavam bem assim. Existir, claro que existiam, no entanto, era preciso que fossem descobertas pelos próprios portugueses ou, então, em último caso, que fossem reveladas por outrem. Aí é que entra, segundo Mário Casassanta, a figura do brasileiro Eduardo Prado, amigo particular de Eça de Queirós, de quem foi freqüentador assíduo da casa.

Ao que pensamos, Eduardo Prado contribuiu poderosamente para o reaportuguesamento dos Vencidos, em especial Eça, Ramalho e Oliveira Martins: era ele mais português do que eles, tal a compreensão que bem cedo adquiriu da cultura portuguesa. ${ }^{64}$

Esta opinião de Mário Casassanta chega a ser aceitável quando se leva em conta que Eduardo Prado vinha de um país novo, ainda em fase de

\footnotetext{
${ }^{63}$ Ibidem, p. 130.

${ }^{64}$ Mário Casasanta, in Eduardo Prado, Trechos escolhidos, p. 38.
} 
formação e cuja independência havia sido conquistada há pouco mais de cinqüenta anos. Portugal, que já havia conhecido seu período de glória, possuía séculos de história, de tradição, de cultura. Natural, pois, um certo alumbramento de Eduardo Prado diante do país que, culturalmente, maior influência havia exercido sobre o seu. Mais ou menos a mesma coisa que estava se passando com Ramalho em relação à França.

Para completar este pequeno estudo sobre o Em Paris, vale ainda a pena comentar dois outros capítulos: aquele que abre e aquele que fecha 0 livro de Ramalho Ortigão.

No primeiro deles, intitulado "No asfalto parisiense", o pretexto de procurar, com uma carta de apresentação, um fidalgo elegante da sociedade parisiense serve de base para a narração de uma história de casamento, adultério e morte, tudo muito ao gosto romântico em que, obviamente, não poderiam faltar a esposa virtuosa, o fidalgo endinheirado e a cortesã interesseira. Muito mais um exercício de ficção do que propriamente observação da realidade, este capítulo, que tinha em sua origem um folhetim, evidentemente era endereçado, como uma espécie de brinde, ao público feminino de ambos os jornais.

Este livro de Ramalho Ortigão, que é o primeiro de uma série de obras com relatos de viagem, fecha-se com um capítulo que embora tenha sido intitulado "A mocidade" trata particularmente de venerandos senhores cujo espírito não envelhecia, personalidades como Alexandre Dumas, pai, como o maestro Auber, que aos oitenta anos nunca jantava só, sendo, porém, raríssimo o homem que alcançava a honra de "obter um talher em seus banquetes ordinários" ${ }^{\prime 65}$; como o cronista Jules Janin, que aos setenta anos de idade ainda tinha fôlego para escrever um folhetim por semana.

É ao falar dos folhetins deste jornalista que Ramalho indaga da utilidade desta seção nos periódicos da época, questionando este texto, ordinariamente de cunho literário, às vezes mundano, às vezes de crítica: leve e despretensiosa em alguns casos, grave e presunçosa em outros. A resposta dada à própria indagação, a despeito da tonalidade irônica que os pronomes de

\footnotetext{
${ }^{65}$ Ramalho Ortigão, Em Paris, p. 279.
} 
tratamento encerram, revela uma das funções do folhetim da época, o que, muito de perto, corresponde a uma das funções da crítica moderna. Nada melhor para revelar esta correspondência do que aquilo que ele mesmo diz sobre a serventia do folhetim da época:

O folhetim serve, ó arganazes de sabedoria e de insipidez, para vos fazer apreciar o que vós não apreciaríeis sem ele; para vos dar o consolo e o orgulho de admirar o que vos passava despercebido se não vo-lo notassem, para vos fazer reler um livro e ouvir segunda vez uma comédia que não tínheis entendido, oferecendo-vos a doce comoção do entusiasmo que a presença do belo não vos produziria se uma terceira cabeça não o explicasse ao vosso juízo, se uma mão de fora não o metesse no vosso coração. ${ }^{66}$

E é justamente isto o que Nelly Novaes Coelho julga ser a base sobre a qual se assenta a principal função de Ramalho como escritor: "Ver, analisar, compreender e fazer ver e compreender o que os outros por si só não perceberiam..." ${ }^{\prime 67}$. A bem da verdade, isto é tudo o que se há esperar de um bom crítico, seja ele deste ou daquele século!

Enfim, fica da leitura deste livro a impressão de um Ramalho orgulhoso por se achar na capital francesa funcionando como correspondente de dois importantes jornais portugueses: O Jornal do Porto e o Diário de Notícias. Algumas vezes, a vaidade e o desejo de ser notado faz com que deixe a modéstia de lado e passe a fazer uso de uma linguagem afetada, presente no uso abusivo de termos e expressões francesas, assim como de neologismos que, embora prontos e acanhados, revelam e traduzem claramente o espírito da obra. Caso típico, por exemplo, de "boulevardando".

É isso aí, o professor de francês e o folhetinista portuense estiveram Em Paris a "boulevardar".

\footnotetext{
${ }^{66}$ Ibidem, pp. 277, 278.

${ }^{67}$ Nelly Novaes Coelho, in Ramalho Ortigão, Trechos escolhidos, p. 16.
} 


\section{Ramalho Ortigão e a Questão Coimbrã}

Ainda antes da mudança definitiva para Lisboa, justamente no ano anterior à viagem para Paris, publica Ramalho o opúsculo $A$ literatura de hoje, intervindo com este folheto na Questão Coimbrã, a polêmica que, como se sabe, marca o início da ruptura entre duas tendências artísticas e duas gerações de escritores portugueses: os românticos de um lado e os realistas de outro.

Ramalho, que a rigor não pertencia a nenhuma destas duas gerações ${ }^{68}$, procura em seu opúsculo manter um certo distanciamento crítico que the permitisse apontar erros e acertos de ambos os lados. No fim das contas, este procedimento só serviu mesmo para desapontar as duas partes envolvidas na questão.

Primeiramente, desapontou Castilho ao se ocupar da carta por este endereçada ao editor do Poema da mocidade, um texto crítico que serviria de posfácio ao livro de Pinheiro Chagas, e logo em seguida, desapontou Antero de Quental e Teófilo Braga ao tratar dos recursos literários e da participação de ambos na polêmica.

Admirador confesso de Castilho - o poeta - a quem considerava um perfeito metrificador e um brilhante estilista, ia ao extremo de acreditar que a perenidade da arte do cantor dos Ciúmes do bardo estava condicionada à própria perenidade da língua. Exatamente isto é o que se entende quando ele diz que as obras do poeta permaneceriam vivas "enquanto a boa e genuína fala portuguesa se usar e prezar na terra"69. E com isto, ao que parece, a História da Literatura não quer concordar!

Mas se ele respeitava e admirava a obra poética de Castilho, o mesmo já não se dava em relação ao crítico prefaciador de poemas alheios. Tanto é assim que não poupou o autor da "Carta ao editor Pereira" - estopim de

\footnotetext{
${ }^{68}$ Nascido em 1836, estava mais próximo de Antero pela idade, porém, intelectualmente muito mais identificado com Castilho.

${ }^{69}$ Ramalho Ortigão, Figuras e questões literárias, v. I, p. 95.
} 
toda a polêmica ${ }^{70}$ - a quem fez uma série de restrições, condenando especialmente a referência (auto-elogiosa), feita por ele, às próprias obras e ao trabalho que desenvolvia; também, não concordou com a solicitação ao ministro do reino para nomeação de Pinheiro Chagas para a cadeira de Literatura Contemporânea do Curso Superior de Letras e, sobretudo, repudiou a recomendação da substituição de Os Lusíadas, pelo $D$. Jaime nas escolas de ensino básico. Agora, é sempre válido repisar, os méritos do poeta jamais deixou de reconhecer e alardear.

Quanto ao que diz respeito a Antero de Quental e Teófilo Braga, Ramalho demonstra em vários passos de seu opúsculo não se ter dado conta dos ideais esteticamente renovadores que eles apresentavam, da mesma forma como parece não ter comungado com os ideais politicamente revolucionários que eles defendiam.

A Antero de Quental, sobre quem mais desenvolvidamente discorre, despreza tanto o poeta quanto o filósofo e depreende-se do pouco que fala sobre Teófilo Braga que aceita o poeta, mas não acata o filósofo.

O julgamento que Ramalho faz da obra e da pessoa de Antero, além de ora injusta, ora equivocada, foi tão acrimoniosa e contundente, atingindo-o tanto no plano intelectual, como no pessoal, que a certa altura parece hesitar diante do comprometimento que a sua crítica poderia acarretar e acrescenta:

Não sei se me desmarco de algum limite nas palavras que dirijo ao Sr. Antero de Quental; sei que as não medi por conveniência, que entendo dever pôr de lado para dizer a verdade limpa; sei que mas ditou a consciência, e que as não desdigo amanhã nem depois, antes confirmarei e sustentarei hoje, logo e sempre. ${ }^{71}$

E rigorosamente não as desdisse, mesmo quando, um mês após a publicação de seu opúsculo, se viu obrigado a sustentá-las, enfrentando Antero em duelo a florete no Arco de Água, um subúrbio do Porto, de onde saiu

\footnotetext{
${ }^{70}$ É impressionante o dom de Castilho de provocar polêmicas. O que ocorreu com a "Carta ao editor Pereira", já havia ocorrido com a "Conversação preambular", a introdução ao poema de Tomás Ribeiro. São dois poemas, dois textos de Castilho e duas polêmicas.

${ }^{71}$ Ramalho Ortigão, op. cit., p. 92.
} 
ferido com uma estocada no braço, para surpresa, tanto dos que conheciam a sua habilidade de esgrimista praticante, quanto dos que sabiam da imperícia e do desinteresse de seu oponente pela prática do esporte. Conta-se que, já no Porto, ao ser indagado sobre a sua preparação para o combate, revelou Antero que toda ela se resumia a uns poucos golpes dados, no quintal de sua casa, em Coimbra, aos talos de umas couves galegas lá existentes.

Por sua vez, Ramalho, que era adepto do esporte, muito tempo depois destes acontecimentos, caçoando, confessou a Júlio de Souza ter sido um "diabo" disfarçado em padre o responsável pela sua entrada na polêmica. Tratava-se de pessoa de seu relacionamento, assíduo freqüentador de sua casa, que um dia lhe entrou porta adentro e provocativo foi disparando:

Oh! Ze’Duarte, por que motivo não entras nesta barulheira desancando todos a torto e a direito? Quem vê melhor as coisas é quem está de palanque a gozar o pagode!... Atira para o monte!... ${ }^{72}$

E foi o que Ramalho fez, atendendo mais a um impulso natural, ditado pelo sentimento, do que propriamente por um juízo crítico ditado pela reflexão sistemática sobre o assunto e, ainda, muito provavelmente, sem cogitarem, ele e o padre, nas conseqüências daquele tiro disparado com uma espingarda espalha-chumbo; enfim, situações ou circunstâncias adversas da vida que o próprio crítico, em depoimento ao mesmo Júlio de Souza, reconhece e deplora: "São estas e outras tolices das quais, dentro em pouco, muito e muito nos arrependemos!..."73.

E não dá para duvidar que verdadeiramente tenha se arrependido do que escreveu naquele opúsculo, tais foram as avaliações e vaticínios equivocados que o próprio tempo se incumbiu de lhe ir revelando. Sirva de exemplo o seu prognóstico em relação à frutificação dos ideais estéticos defendidos pelos jovens de Coimbra.

À literatura coimbrã estão cerrados os ecos das consciências; faltam-lhe completamente essas misteriosas vibrações

\footnotetext{
${ }^{72}$ Julio de Souza e Costa, Ramalho Ortigão, memórias de seu tempo, p. 28.

${ }^{73}$ Ibidem, p. 29.
} 
atmosféricas, que fazem com que em acústica o estampido suceda ao golpe, e em literatura o sucesso acompanhe a determinação do talento. $^{74}$

No entanto ela ecoou em muitas consciências, vibrou nas atmosferas, fez grande sucesso e propiciou o aparecimento de vários talentos.

Não fosse Ramalho Ortigão uma personalidade forte e um caráter determinado e este folheto, "A literatura de hoje", teria posto um fim à sua carreira de crítico. Ficou, é bem verdade, de tudo o que houve, alguns ressentimentos e mágoas que talvez sirvam para explicar a sua ausência no movimento geral das Conferências do Casino, bem como a forma esquiva com que tratou da colaboração para o In Memorian de Antero de Quental, a despeito da muita insistência de Luís de Magalhães, organizador da coletânea e responsável pela recolha das contribuições, que só desistiu da sua colaboração depois de ouvir os conselhos de Oliveira Martins, que muito melhor conhecia Ramalho, e que o convenceu de que o livro não valeria menos "por lhe faltarem umas linhas de folhetim literário"75.

Finalmente, em princípio de 1869, muda-se para Lisboa, indo com toda a família ocupar o terceiro andar do prédio no 30 da Calçada dos Caetanos, onde, durante uma certa temporada, teve por vizinho Oliveira Martins, quando então se firmou a amizade que depois sempre os uniu. Foi nesta casa da Calçada dos Caetanos que escreveu a maior parte e sua obra, sediou As farpas, criou os filhos, recebeu os amigos e, por fim, ali padeceu os martírios de uma doença implacável, sofrimentos de que são testemunhas as suas últimas cartas enviadas ao Brasil, para o filho José Vasco.

\footnotetext{
${ }^{74}$ Ramalho Ortigão, op. cit., p.77.

${ }^{75}$ Antero de Quental, In memorian, p. XIV.
} 
Uma vez instalado em Lisboa, toma posse do cargo de oficial de secretaria da Academia Real das Ciências $^{76}$ e passa a colaborar em vários periódicos da capital: Revolução de Setembro, Diário de Notícias, Diário Popular, Jornal do Comércio e Diário da Manhã. Quem fornece esta informação é Júlio de Oliveira, jornalista portuense, o mesmo que, em uma obra sobre Eça de Queirós e Ramalho Ortigão ${ }^{77}$, reuniu uma quantidade significativa de cartas enviadas por este escritor a Manuel Fernandes Reis, seu antigo companheiro de redação em $O$ Jornal do Porto.

$E$ é justamente por intermédio deste antigo companheiro de redação que Ramalho procura obter o posto de correspondente diário em Lisboa da folha portuense. Para tanto, envia-Ihe, em outubro de 1870, uma carta, incumbindo-o de apresentar a Cruz Coutinho, a título de experiência, a seguinte proposta de trabalho: durante uma temporada de quinze dias a um mês o jornal receberia as suas colaborações e, se, ao cabo deste prazo, não houvesse recebido remuneração alguma consideraria que não fizera por merecer, nada mais enviaria e daria tudo por quitado; agora, se Cruz Coutinho julgasse que a correspondência convinha à sua folha, comunicaria antecipadamente o fato e ele então, em vez de parar, continuaria ocupando-se dela e eles então combinariam os honorários.

Esta proposta de trabalho, que hoje nos surpreende e causa espécie, serve para dar uma noção do grau de dificuldade a que estavam sujeitos os profissionais, na época, para o ingresso no quadro de jornalistas de um periódico conceituado. Para melhor compreender este grau de dificuldade é preciso saber que Ramalho tomou conhecimento da possível vacância do posto em Lisboa através de Andrade Ferreira ${ }^{78}$, que lhe pedia intercedesse por seu nome junto à empresa de Cruz Coutinho. E é o que, primeiramente, ele faz, acrescentando em seguida, que se ao jornal não interessasse o concurso

\footnotetext{
76 Quando em novembro de 1910, após mais de cinqüienta anos de uma vida dedicada à literatura, Ramalho Ortigão recebeu o comunicado de sua eleição, pela Classe de Ciências Morais, Políticas e BelasLetras, sócio efetivo desta mesma Academia. Ele que descansava em casa de uma de suas filhas, em Linda-a-Pastora, expediu então uma carta de agradecimento pela distinção, na qual sutilmente censurou a velha instituição ao considerar o gesto um reconhecimento de estima votado muito mais ao funcionário dedicado do que propriamente ao cultor das Belas-letras.

${ }^{77}$ Júlio de Oliveira, Ramalho Ortigão e Eça de Queirós, Porto, 1945.

${ }^{78}$ Possivelmente trate-se de José Maria de Andrade Ferreira (1823-75), escritor e jornalista, crítico literário e teatral, romancista e autor de obras sobre literatura, história e arte dramática.
} 
de Andrade Ferreira ele mesmo se candidataria ao posto e, só aí então, apresenta sua proposta.

Se uma proposta de trabalho como aquela hoje parece inconcebível, já não se pode dizer o mesmo desta outra de que o mesmo amigo Fernandes Reis era também incumbido de levar ao conhecimento de Cruz Coutinho: a proposta de edição de um livro de Eça de Queirós. Tratava-se da obra intitulada Jerusalém e o Cairo, que outra coisa não era senão as impressões da viagem ao Oriente, que Eça havia realizado tempos atrás em companhia do conde de Resende. Eça de Queirós é apresentado, nesta carta, como o amigo íntimo com quem havia escrito, de colaboração, os folhetins de O mistério da estrada de Sintra. Além disso, Ramalho, empenhando a palavra de crítico, assegura que o amigo era um escritor de muito talento e a sua obra "extremamente literária"79 - seria interessantíssima para o jornal. Eis os termos em que foi vazada a proposta de edição desta obra de Eça de Queirós:

O livro publica-se em folhetim, estando feito no estilo mais próprio para esse fim; aproveita-se a composição para a impressão em volume; tiram-se os exemplares que o senhor Cruz Coutinho desejar para si e dão-se ao autor 200 exemplares por única remuneração da publicação em folhetim e em volume. ${ }^{80}$

Muito tempo depois, esta obra foi publicada com outro nome e sob condições muito diversas, mas para a época, as exigências não poderiam mesmo ir além, e isto até nem é para causar tanto espanto quando se tem em conta que hoje em dia há muito autor aceitando condições ainda mais humilhantes.

Tanto não poderiam ser mais que, mesmo sendo tão poucas, a proposta não foi aceita. O Jornal do Porto não publicou os folhetins de Jerusalém e o Cairo, Cruz Coutinho não editou a obra em volume e, mais que isso, dispensou os préstimos de seu antigo colaborador, conseqüência talvez

\footnotetext{
${ }^{79}$ Júlio de Oliveira, op. cit., p. 48.

${ }^{80}$ Ibidem, pp. 47, 48.
} 
de algum mal entendido que a correspondência recolhida por Júlio de Oliveira deixa, às vezes, transparecer ${ }^{81}$.

Mas, como a roda da fortuna (ora abaixo, ora acima) não descansa, o que um negou, outro deu. O responsável pela dádiva foi uma publicação surgida no Porto em novembro de 1870 e que se constituiu em uma grande promessa jornalística daquela cidade. Infelizmente ficou só na promessa e O Progresso do Porto - assim se chamava a publicação - fechou as portas em março de 1871.

Mas, como a correspondência era diária, mesmo tendo durado pouco, houve tempo para Ramalho enviar à folha portuense um tão farto material que mesmo após rigorosa seleção por parte dos editores foi suficiente para preencher dois volumes de suas obras completas, publicados, postumamente, com o mesmo título da seção do jornal: Correio de hoje.

Constitui a base deste material um conjunto de pequenas notas sobre o movimento cultural e a Lisboa da época, entremeados de breves e superficiais comentários críticos, além de apreciações sobre o parlamento ou sobre os costumes da capital; uma correspondência cujo critério de valor levava mais em conta a quantidade do que a qualidade e, por isso mesmo, tem ela hoje apenas interesse documental. Ramalho seguiu à risca o manual dos correspondentes noticiosos: muita informação e pouca elaboração. Tanto foi fiel ao princípio que preferiu não subscrevê-las, considerando seu pouco valor literário.

Singulares, pela curiosidade, nesta correspondência, são estas três notas literárias enviadas, em 19 de janeiro de 1871, aos leitores portuenses.

O Sr. José Maria Eça de Queirós, um dos autores do Mistério da estrada de Sintra, está compondo um livro intitulado História de um lindo corpo. É um romance de que têm ouvido alguns trechos os amigos mais particulares do autor, que lhe fazem os

\footnotetext{
${ }^{81}$ É o caso, por exemplo, da queixa quanto à ausência de comentários críticos por parte dos jornalistas ao livro $O$ mistério da estrada de Sintra, enviado por Ramalho ao escritório da empresa. Como não davam mostras de tê-lo recebido, mantendo a seu respeito um silêncio absoluto, ele, indignado, questiona: "Seria também compreendido o livro no desagrado em que incorreu o autor?” (Júlio de Oliveira, op. cit., p. 61)
} 
maiores elogios, considerando-o um livro destinado a fazer a mais profunda impressão.

O Sr. Antero de Quental escreveu um livro que tem o seguinte assunto: Programa de estudos para as gerações futuras.

Anjos Peres, filhos \& companhia é o título de um novo romance de Ramalho Ortigão. ${ }^{82}$

Tão curioso quanto esta notícia é o fato de nenhuma das obras anunciadas terem sido dadas a público e, pelo que se sabe até o momento, a única a ser inteiramente concluída foi o Programa de estudos para as gerações futuras. Desta obra que denominava - diferentemente de Ramalho - Programa para os trabalhos da geração nova, fala Antero, em cartas, a Oliveira Martins e Teófilo Braga, garantido aos amigos tratar-se de trabalho sério, no qual fazia "uma exposição das idéias revolucionárias" 83 , tanto no campo da filosofia e da política, quanto no campo da economia e da moral. Até esta altura, parecia entusiasmado com o livro, no entanto, Fidelino de Figueiredo acredita que, ao perceber a facilidade com que poderiam ser refutadas algumas de suas afirmações, Antero destruiu a obra ${ }^{84}$.

Quanto ao romance Anjos Peres, filhos \& companhia não se conhece nenhuma outra referência a este texto. Talvez fosse uma das obras do projeto que Ramalho acalentou de escrever uma comédia da vida burguesa, em Portugal, mas isto não passa de especulação, como também é especulação quase tudo o que se fala sobre a História de um lindo corpo, este trabalho de Eça de Queirós que ninguém sabe ao certo do que se tratava, nem tampouco o fim que levou.

O que se sabe - pelo que informa Jaime Batalha Reis no texto que serviu de introdução às Prosas Bárbaras - é que os amigos particulares que tinham "ouvido alguns trechos", lidos por Eça de Queirós, eram justamente ele e Antero de Quental, que, por esta época, com ele dividia o aluguel da casa onde se reuniam os rapazes do Cenáculo. Assim ele conta o caso:

\footnotetext{
${ }^{82}$ Ramalho Ortigão, Correio de hoje, v. II, p. 27, 28.

${ }^{83}$ Antero de Quental, Cartas I, in Carlos Reis, As conferências do Casino, p. 51.

${ }^{84}$ Fidelino de Figueiredo, História da literatua realista, p. 42.
} 
Um dia veio mostrar-nos, ao Antero de Quental e a mim, o primeiro esboço, muito desenvolvido - tão extenso que levou várias noites a ler - dum romance intitulado História de um lindo corpo. $^{85}$

Batalha Reis considera esta a primeira manifestação positiva do realismo na escrita de Eça de Queirós. Se realmente ele tiver razão e forem consideradas as épocas, primeiro, da correspondência de Ramalho (princípios de 1871) e, segundo, das Conferências do Casino (meados do mesmo ano), bem como se for lembrado que o assunto tratado por Eça em sua conferência foi justamente o realismo na arte, fica então evidente que antes de tratar o tema teoricamente, já dele cuidava Eça na prática da escrita e, assim sendo, se outra utilidade não teve, ao menos serviu esta História de um lindo corpo para que ele formasse a mão e preparasse o espírito para os caminhos novos que se apresentavam.

Muito pouca coisa mais haveria a dizer sobre o Correio de hoje, o que fica para uma outra oportunidade.

O Cenáculo e as Conferências do Casino

No balanço geral da intervenção de Ramalho na Questão Coimbrã, embora ele tentasse uma posição autônoma e independente, é lícito afirmar que, intelectualmente, ele estava muito mais comprometido com os velhos de Lisboa do que com os jovens de Coimbra. Além das razões apontadas anteriormente, talvez seja este mais um dos motivos que o fizeram passar mais ou menos ao largo da agitação intelectual promovida pelos rapazes do Cenáculo, na maioria, jovens coimbrãos que agora também se achavam em Lisboa.

Nas lembranças deixadas por Jaime Batalha Reis no In memorian de Antero de Quental, intituladas “Anos de Lisboa”, registra-se o aparecimento

\footnotetext{
${ }^{85}$ Eça de Queirós e Jaime Batalha Reis, Cartas e recordações de seu convívio, p. 129.
} 
tardio e mesmo assim esporádico de Ramalho Ortigão, não já na Travessa da Guarda-Mor, palco das primeiras reuniões do Cenáculo, mas na casa de São Pedro de Alcântara, para onde haviam se mudado Batalha Reis e Antero de Quental, já a esse tempo, amigos inseparáveis.

Mesmo as suas impressões a respeito do Cenáculo divergem de outros testemunhos mais dignos de confiança, depoimentos de participantes mais ativos daquela boêmia literária, que estavam, seguramente, muito mais familiarizados com ela do que Ramalho, que teve, junto ao grupo, uma presença discreta e uma atuação apagada.

Contudo, é oportuno mais uma vez lembrar que o grupo de jovens que formava o Cenáculo pertencia a uma geração posterior à de Ramalho e se compunha, em grande parte, de uma rapaziada ainda indefinida quanto aos caminhos a seguir na vida, diferentemente da situação vivida por ele: casado, com filhos e com os encargos de oficial na Academia de Ciências, principal razão de sua vinda para Lisboa.

Mas, enfim, ele que já havia publicado, em co-autoria com Eça de Queirós, O mistério da estrada de Sintra, que, modestamente, considerava um "devaneio literário de dois rapazes obscuros" ${ }^{86}$ e, somente de sua autoria, as Histórias cor-de-rosa, uma de suas raras incursões pelo campo da ficção, além do livro de viagem, Em Paris, e do opúsculo, $A$ literatura de hoje, ele, com toda esta bagagem literária, não participa das Conferências do Casino, idealizadas por Antero de Quental.

Todavia, alguém pode argumentar que esta ausência esteja intimamente relacionada com a questão pessoal em que estiveram envolvidos ele e o poeta e tenha, portanto, um fundo emocional. Júlio de Souza Costa ${ }^{87}$, por exemplo, percebeu que, embora Ramalho Ortigão elogiasse os sonetos, não demonstrava qualquer simpatia pela pessoa de Antero.

Seria pela estocada no braço, apanhada no duelo, ou pelo equívoco do juízo crítico que o opúsculo $A$ literatura de hoje e a passagem do tempo, mais que tudo, se ocupavam de patentear?

\footnotetext{
${ }^{86}$ Ramalho Ortigão, Correio de hoje, v. II, p. 153.

${ }^{87}$ Júlio de Souza e Costa, Ramalho Ortigão, memórias de seu tempo, p. 32.
} 
Não se sabe, mas, de qualquer maneira, parece muito estranho que, embora morando em Lisboa e sendo amigo de Eça de Queirós, Ramalho Ortigão sequer tenha assinado o programa das Conferências do Casino, divulgado em 16 de maio de 1871, enquanto Guilherme de Azevedo, por esta ocasião ainda residindo em Santarém e só esporadicamente aparecendo em Lisboa, seja um dos dez signatários ${ }^{88}$.

É bem provável que as ligações de Ramalho com o Cenáculo tenham sido, em geral, intermediadas por Eça de Queirós, o pupilo dos tempos do Porto que se tornara amigo nos tempos de Lisboa.

É também muito provável que a sua ausência nas Conferências do Casino se deva ao fato de que para maio - o mesmo mês destas conferências - estava programado o lançamento do primeiro número de $A s$ farpas. Tantos deviam ser os compromissos e afazeres - a ele que era ao mesmo tempo diretor, editor e um dos dois redatores daquela publicação - que nem mesmo era capaz de por em dia a correspondência com Fernandes Reis e se desculpava com o amigo, alegando: "me têm tirado imenso tempo os negócios econômicos e os negócios literários das Farpas"89.

O pequeno fragmento acima transcrito faz parte de uma carta que, redigida poucos dias antes do lançamento do primeiro opúsculo, dá bem a medida, para quem a lê integralmente, da enorme expectativa de Ramalho em relação ao novo trabalho e aos novos caminhos que ele e Eça de Queirós principiavam a trilhar. Mais que isso, até, esta carta revela a crença inabalável que ele tinha no valor intrínseco daquele folheto.

No meio do ramerrão hipócrita do jornalismo e da literatura contemporânea esse livro tornar-se-á sensível e virá talvez a ser apontado na história do pensamento moderno como um grande impulso das idéias para o direito e para a justiça. ${ }^{90}$

Muita alegria e confiança - cautelosamente temperadas com uma boa pitada de realismo - ressuma desta carta em que, vaidoso, comunica ao

\footnotetext{
${ }^{88}$ O poeta da Alma nova só viria para a capital, viver exclusivamente de sua pena de jornalista, no ano de 1874, sendo até então rara e esporádica sua presença em Lisboa.

${ }^{89}$ Júlio de Oliveira, Ramalho Ortigão e Eça de Queirós, p.78.

${ }^{90}$ Ibidem, p. 78.
} 
antigo companheiro de redação o pedido de um fotógrafo interessado em pôr a venda, "juntamente com o primeiro número das Farpas"191, um retrato dele e de Eça de Queirós.

Outras cartas, tratando das questões financeiras da publicação que tinha em Fernandes Reis o seu correspondente no Porto, são enviadas. Em uma delas Ramalho pede ao amigo que pergunte a Cruz Coutinho se lhe autorizaria anunciar que o correspondente de As farpas poderia ser procurado diretamente nos escritórios de seu jornal.

Fica visto assim que pela segunda vez Ramalho solicita a intervenção de Fernandes Reis para tratar de negócios de seu interesse junto ao proprietário de $O$ Jornal do Porto, demonstrando deste modo ter havido mesmo algum desentendimento entre eles. Não se sabe exatamente o que houve, todavia é certo que seu nome havia sido vetado pelo empresário que baixara ordem aos correspondentes de seu jornal em Lisboa para não fazerem qualquer referência ao nome de Ramalho, estando, portanto, todos - lastimava o escritor - proibidos de "falarem em mim"92.

Estas desavenças e as pequenas humilhações, a que esteve sujeito, não foram suficientemente fortes e determinantes para que Ramalho deixasse de escrever uma página de simpatia e admiração ${ }^{93}$, na morte de Cruz Coutinho, nem tampouco foram bastante para abalar seu ânimo, pois tudo era compensado pelo sucesso dos "livrinhos", cuja tiragem aumentava a cada nova edição.

\footnotetext{
${ }^{91}$ Ibidem, p. 78.

92 Ibidem, p. 84. época:

"Cruz Coutinho, Cruz Coitado!

Tens o jornal estafado.

Dá-lhe sopas, dá-lhe vinho!

Dá-lhe um passeio no Minho!

Dá-lhe um bacharel formado.

${ }^{93}$ Este texto foi publicado na Gazeta de Notícias em 28 e 29 de junho de 1885 e posteriormente recolhido no volume III de As farpas. É do princípio ao fim pura manifestação de simpatia e consideração pelo livreiro, bem ao contrário do que fez Guerra Junqueiro. Conta Júlio de Oliveira que ao principiar o declínio de O Jornal do Porto e o vigor físico de seu proprietário, o autor da Musa em férias, a quem o livreiro não era simpático, compôs o seguinte epigrama que fez muito sucesso no meio jornalístico da 
Tiramos uma edição de 1.500 exemplares e esgotamos tudo de um mês para o outro. Em Portugal não se pode exigir mais, e ninguém ainda conseguiu tanto cá. ${ }^{94}$

Por seu lado, Eça de Queirós garante que a publicação chegou a atingir a casa dos dois mil assinantes, como se lê em uma carta-resposta enviada de Newcastle, em de 25 de fevereiro de 1878, ao editor Joaquim de Araújo $^{95}$. Este texto, que serviu de legenda a um retrato de Ramalho estampado na capa da revista $A$ Renascença, fundada pelo próprio Joaquim de Araújo, foi postumamente recolhido em Notas contemporâneas.

Já, na circular que David Corazzi - editor responsável pela recolha em volumes dos opúsculos - enviou, em fevereiro de 1887, aos possíveis subscritores da republicação de As farpas, consta que ao tempo em que foram impressas por conta dos próprios autores, praticamente sem anúncio e quase sem "reclamos" (publicidade), eles chegaram a tirar 2.500 exemplares que se esgotavam rapidamente desde o primeiro até o último número.

Há volumes que se pagam por cinco e seis vezes o seu custo primitivo, e as coleções completas, raríssimas, têm os mais altos preços estimativos, não obstante haverem sido quase todos os números reproduzidos no Brasil em jornais e em livros. ${ }^{96}$

Sabendo que o custo primitivo dos opúsculos era de 200 réis e romances como, por exemplo, $A$ freira do subterrâneo e $A$ vingança da marquesa, respectivamente de Camilo Castelo Branco e Ponson du Terrail, era de 500 réis, contabiliza-se um valor, comparativamente, alto para cada exemplar, que tinha em média cem páginas, além de um ganho considerável para os autores que reuniam condições de lançar um por mês.

O sucesso dos "livrinhos" (formato $11 \times 14 \mathrm{~cm}$, tendo na capa um diabo faceto, de riso em riste, luneta e asa de morcego) foi tanto e o interesse

\footnotetext{
94 Júlio de Oliveira, Ramalho Ortigão e Eça de Queirós, p. 84.

95 Resultou desta carta-resposta de Eça de Queirós um belo estudo que, pondo em pé, com os traços principais a estampa do amigo, punha também em relevo o meio literário em que ambos se haviam formado, semelhantemente ao que viria a fazer, quase vinte anos depois no In memorian de Antero de Quental, no texto intitulado "Um gênio que era um santo", que também foi recolhido em Notas contemporâneas.

${ }^{96}$ Circular de David Corazzi, in, Ramalho Ortigão, As farpas XV, p. 251.
} 
despertado tão grande, superando mesmo as expectativas mais otimistas, que Ramalho, às voltas para atender requisições de números atrasados, assim respondia a uma encomenda do editor Chardron: "Nós não temos coleções nem volume algum dos meses passados. Nem mesmo do último. Tudo está vendido" 97 .

E tudo isso sem contar a contrafação brasileira ${ }^{98}$ que grassava e corria solta em Recife e no Rio de Janeiro, onde "têm ganho contos de réis aqueles que nos roubam"99, como diz Ramalho a Fernandes Reis, confidenciando ter obtido a confirmação do esbulho por um novo adido brasileiro, que recém-chegado para a embaixada de Lisboa, havia feito a delicadeza de o visitar, "apesar das sovas"100 que garantia ter aplicado nos brasileiros.

Possivelmente estas "sovas" estejam relacionadas com a polêmica travada em 1872 entre os autores de As farpas e os jornalistas pernambucanos, estopim de manifestações anti-lusitanas ocorridas na cidade do Recife e em uma outra, dela distante 50 quilômetros, chamada Goiana. Chegaram a tal ponto os corre-corres e quebra-quebras provocados por brasileiros e portugueses, que as autoridades se viram obrigadas a suspender as festividades de rua, programadas para comemorar o cinqüentenário da independência do Brasil.

Aliás, estas ocorrências serviram de tema a Paulo Cavalcanti ${ }^{101}$ e estão fartamente documentadas em obra que trata do papel de Eça de Queirós nestas agitações de rua. Após diligente pesquisa, Cavalcanti reuniu material suficiente para estudar o envolvimento dos dois autores de As farpas no episódio das manifestações contra os portugueses, arruaças que no fundo reproduziam ecos tardios da guerra dos Mascates e não eram mais que reflexo do velho espírito de rivalidade e competição, com origem nos tempos da guerra contra os holandeses, entre colonos povoadores e colonos reinóis, como eram chamados os portugueses que aportavam no Recife, ora na condição de

\footnotetext{
${ }^{97}$ Júlio de Oliveira, op. cit., p.87.

${ }^{98}$ Para se fazer uma idéia do que foi esta contrafação é suficiente saber que As farpas tinham apenas dois assinantes no Brasil, onde, diga-se de passagem, eram tão conhecidas como em Portugal.

99 Júlio de Oliveira, op. cit., p. 84.

${ }^{100}$ Ibidem, p. 84.

${ }^{101}$ Paulo Cavalcanti, Eça de Queirós, agitador no Brasil, S.P., Editora nacional, 1966.
} 
burocratas do reino, ora na qualidade de aventureiros ambiciosos, ávidos de lucros fáceis e enriquecimento rápido.

Vem, portanto, desde os tempos heróicos das guerras flamengas o sentimento nativista e o orgulho patriótico dos colonos que serviram à terra, bateram-se por ela e a reconquistaram aos holandeses, e quem sabe não seja mesmo este sentimento nativista e este orgulho patriótico dos pernambucanos a principal razão de, somente, naquela província os textos de As farpas terem suscitado tamanha violência.

É bem verdade que estas farpas pertenciam aos tempos áureos da iconoclastia, do bota abaixo, do riso aberto, largo, solto e provocativo, com firme e determinado propósito de agitar os ânimos entibiados, de aluir as instituições empedernidas, de chacoalhar a sociedade estagnada. O lema da bandeira que empunhavam era indubitavelmente o preceito latino do castigat ridendo mores.

Em que pese as observações restritivas de Arnaldo Faro ${ }^{102}$ e João Medina ${ }^{103}$, o estudo que Paulo Cavalcanti fez da recepção destas farpas na província de Pernambuco é desses trabalhos em que o autor praticamente esgota o tema, impossibilitando, em tese, o acréscimo de novas e substancias informações, tornando por isso mesmo sem propósito, em um trabalho com outro horizonte como é o caso deste, a tentação de realizá-lo.

É melhor deixar que falem, sobre este assunto, Cavalcanti, Faro e Medina.

\section{A saída de Eça de Queirós}

Em outubro de 1872, depois de quinze números publicados, Eça de Queirós deixou As farpas, designado que fora pelo governo português para servir na embaixada de Havana. Ramalho Ortigão, ou por não encontrar

\footnotetext{
102 Arnaldo Faro, Eça e o Brasil, S. P., Editora Nacional, 1977.

103 João Medina, Eça de Queirós, aintibrasileiro?, Bauru, Edusc, 2000.
} 
substituto à altura, ou por exclusiva e total auto-suficiência, muito própria de seu feitio, seguiu sozinho com a publicação, conquanto mantivesse o nome do ex-colaborador na capa dos opúsculos: no alto, junto à cabeça do diabo faceto, no melhor lugar - "por uma tocante superstição de amizade"104.

Eça de Queirós, do alto de seu consulado cubano, situado do outro lado do Atlântico, adquiriu, então, status de principal crítico da publicação.

O seu primeiro número, a "sós", das Farpas, era simplesmente relampejante de humorismo; o segundo é inferior - mas há nele espírito ainda bastante para alimentar um Paris de província durante uma semana. ${ }^{105}$

Porém, como era leitor atento e profundo conhecedor do caráter do amigo, distinguia e notava uns cambiantes novos apresentados pelos folhetos e, temendo talvez a conversão daquilo que considerava uma "alegre catapultazinha"106 em uma austera e carrancuda cátedra acadêmica, prudentemente, aconselhava ao antigo mestre: "Não se descuide de ser alegre: só a alegria dá alma e luz à Ironia - à Santa Ironia - que sem ela não é mais que amargura vazia"107.

E não era sem fundamento a sua preocupação, pois, assim que deixou a publicação, Ramalho, pondo um pouco de lado o tom sarcástico e o riso irônico, procurou realmente transformá-la em uma tribuna de onde pudesse ensinar o povo a se vestir, a comer, a morar, enfim, a ter uma vida mais em conformidade com os novos hábitos de higiene, já adquiridos por outros povos.

Essa intenção de dar aos folhetos mais uma feição de "cátedra" do que de "catapulta" não era coisa nova, vinha desde os tempos em que ainda fazia parte da redação e é ele próprio quem fala desta pretensão pedagógica do amigo naquela sua carta-resposta a Joaquim de Araújo. Conta Eça que, ao tomar ciência de que As farpas possuíam em torna de seis mil leitores,

\footnotetext{
${ }^{104}$ Eça de Queirós, Notas contemporâneas, p.47.

${ }^{105}$ Idem, Correspondência, pp. 19, 20.

${ }^{106}$ Idem, Notas contemporâneas, p. 44.

${ }^{107}$ Idem, Correspondência, p. 20.
} 
Ramalho lhe fez a seguinte proposta: “- E se, aproveitando um tal auditório, nós Ihe ensinássemos alguns princípios?”108.

$E$ foi realmente o que aconteceu. Assim que se viu sozinho à frente da publicação, Ramalho foi gradualmente substituindo a jocosidade irônica, mais apropriada ao folhetim, pela austeridade aparatosa, própria dos artigos de fundo e, pouco a pouco, encaminhando a publicação - como já havia demonstrado interesse - para a esfera da pedagogia, no firme propósito de ensinar alguns princípios e, ao mesmo tempo, dar aos folhetos umas pinceladas de verniz científico.

Mas, como para ensinar é preciso antes aprender, Ramalho procura inteirar-se dos novos conhecimentos trazidos pela comunidade científica, adquirindo informações básicas nas áreas de economia, história, arte, política, filosofia, higiene e outras; tudo porque estava convencido de que um jornalista devia possuir em dose suficiente, mesmo que de forma generalizada, os princípios básicos do movimento artístico e científico de seu tempo.

Com uma curiosidade infantil e uma determinação religiosa, estudou as obras que veiculavam esses novos conhecimentos, provendo-se de noções elementares que levava aos leitores, transformando os folhetos, outrora iconoclastas, em "uma janela aberta" que deixava entrar em Portugal e ricochetear no Brasil, "grandes rajadas de civilização e de educação", rajadas estas que, varrendo os miasmas deletérios, traziam "sempre alguma boa semente" 109 .

Eça de Queirós era um dos principais leitores destes opúsculos e constituíam um dado constante das suas cartas a Ramalho, desde Havana a Newcastle, as reclamações, as cobranças e as solicitações de envio dos folhetos que ele considerava a "obra mais viva da literatura portuguesa" ${ }^{110}$.

Meu pai - que sabe bem como eu estimo que me falem de si e não se esquece nunca de me dar essa satisfação - diz-me, numa

\footnotetext{
${ }^{108}$ Idem, Notas contemporâneas, p. 44.

${ }^{109}$ Ibidem, p. 45.

${ }^{110}$ Ibidem, p. 47.
} 
carta que recebi ontem, que você lhe prometera - há uns bons quinze dias - mandar-me o último volume das Farpas. ${ }^{111}$

O termo seguinte deste fragmento outra coisa não era senão a cobrança do envio do "volume encantado" que ainda não havia recebido.

Grande admirador da obra de Ramalho, Eça não só cobrava reiteradamente a remessa dos fascículos como os lia com olhos acostumados a sondar a alma humana, faculdade que, junto com a intimidade e a convivência mútua, lhe permitiam discernir e perceber disposições psíquicas do amigo, coisas que a outros poderiam passar despercebidas.

Já li as Farpas: o volume é bom - ainda que você tem feito melhor. O artigo sobre o soldado tem bom-senso, um grande ar e muito humour. Parece-me, porém, que este volume tem um aspecto geral de tristeza: acho que todo aquele riso é um pouco contrafeito e tem vontade de chorar; a idéia da morte aparece a cada momento. Que diabo tem você? Fez-me uma certa impressão lê-lo. ${ }^{112}$

E outras observações, tanto concernentes ao aspecto moral quanto ao aspecto estilístico, são repassadas a Ramalho pelas cartas de Eça. Quem lê esta correspondência percebe claramente que existiu mesmo uma fraterna amizade entre os dois escritores que, juntos, empreenderam a publicação de As farpas, cujos artigos eram propositadamente anônimos, como se os movessem o firme propósito de confundir o leitor quanto à autoria.

Nesta fase de dupla autoria, os artigos formavam, de acordo com João Medina, um bloco tão "coeso de duas inteligências e duas penas, tão estreitamente unidas (e confundidas) que só"113 na capa dos opúsculos, pelo nome dos autores, se achavam verdadeiramente separadas.

Para quem leu estas notas desde o princípio, não é segredo nenhum que Eça de Queirós já tratara com Ramalho Ortigão muito tempo antes do sucesso de As farpas e até mesmo da aventura de $O$ mistério da estrada de Sintra, e, justamente, por este conhecimento e, também, por ter

\footnotetext{
${ }^{111}$ Eça de Queirós, Correspondência, pp. 35, 36.

112 Ibidem, pp. 38, 39.

113 João Medina, Eça de Queirós, antibrasileiro?, p. 117.
} 
acompanhado a evolução literária do amigo, propõe a tese de que foram $A s$ farpas a principal responsável pelo desbaste em seu estilo, dando-lhe a maleabilidade necessária ao tratamento das novas matérias e à veiculação das novas idéias, desembaraçando sua prosa da "velha armadura quinhentista"114 que antes a envolvia, fazendo, por fim, emergir um novo estilo, vivo, cortante e harmonicamente afinado com a ironia, a poderosa arma que agora ele empunhava.

As farpas publicaram-se de 1871 a 1882 em quatro séries distintas: na primeira delas, editaram-se vinte e seis números, sendo que, desses, quinze foram em dupla autoria; na segunda, dez números; na terceira e na quarta séries, imprimiram-se apenas três números para cada uma delas. Em 1887 foram reunidas em volumes e editadas por David Corazzi, da Companhia Editora Nacional, tanto os textos de autoria de Ramalho Ortigão, quanto os de autoria de Eça de Queirós, sendo que em ambos os casos os autores procederam a uma seleção do material a ser editado em livro. $O$ título, As farpas, ficou para Ramalho Ortigão, a quem Eça de Queirós atribuía a paternidade do projeto, preferindo chamar a sua produção de Uma campanha alegre.

Quando em 1945 a Livraria Clássica Editora se propôs editar a obra completa de Ramalho Ortigão, resgatou todo o material rejeitado na primeira edição em livro (onze volumes) e reuniu em um conjunto de quinze volumes tudo o que havia sido publicado nos opúsculos. Esse material resgatado está distribuído pelos tomos XII, XIII, XIV, XV de As farpas.

"Obra única na literatura portuguesa", no entender de Fidelino de Figueiredo, elas representam, pelo seu valor literário e intelectual, "o mais perfeito modelo de crítica social" ${ }^{115}$ produzido no século XIX, em língua portuguesa.

\footnotetext{
${ }^{114}$ Eça de Queirbós, Notas contemporâneas, p.39.

${ }^{115}$ Fidelino de Figueiredo, História da literatura realista, p. 290.
} 
Outros trabalhos

Em 1875, Ramalho Ortigão publica um livro intitulado Banhos de caldas e águas minerais, com introdução de Júlio César Machado e ilustração de Emílio Pimentel.

As caldas eram fontes de águas termais espalhadas por várias províncias de Portugal e que se tornavam estações de banhos e tratamentos. Verdadeira mania da época, estes balneários eram freqüentados pelos elegantes, pelos homens de negócios, pelos políticos que deles se aproveitavam para brandamente se exercitarem, fazerem pique-niques, tomarem banhos, enfim, realizarem uma série de atividades que tinham por finalidade o alívio, o descanso, a distração ou, até mesmo, o tratamento, que no mais das vezes seguia orientação médica.

Em Banhos de caldas e águas minerais, Ramalho faz uma relação destas estações espalhadas pelas províncias portuguesas, orientando os futuros viajantes (turistas ou pacientes) sobre as qualidades terapêuticas de cada uma delas.

Em certa medida, o livro resultou em uma tentativa feliz de elaborar um roteiro ao mesmo tempo útil e agradável aos freqüentadores destes balneários. Portanto, não foi em vão que consultou tratados de hidroterapia, leu relatórios dos institutos de análises químicas, estudou os trabalhos consagrados aos efeitos terapêuticos das águas; mas, seja por orientação dos compêndios, seja por uma questão de ética, procurou alertar os leitores para os variados fins a que se destinavam estes banhos e, no caso específico de tratamento, aconselhou antes uma consulta ao médico, que ele considerava a pessoa ideal para encaminhar o doente à fonte mais indicada a seu caso.

Para Júlio César Machado, que elaborou uma introdução perfeitamente ajustada à idéia do livro, a elegância estilística e o rigor formal com que foram descritas as paisagens fazem crescer o desejo de conhecê-las, tornando por isto mesmo a obra de Ramalho uma espécie de caderno de 
viajante que vê, descreve, menciona e aponta, de "forma que se leia sem cansar e acorde o interesse sem se demorar em coisas sabidas ou inúteis" ${ }^{\prime 16}$.

Um ano após a edição do Banho de caldas e águas minerais, Ramalho Ortigão publicou em outro livro um novo roteiro. Deixando de lado o interior, seguiu desta vez pelo litoral de seu país e, sugestivamente, deu a este novo roteiro o título de As praias de Portugal.

${ }^{116}$ Júlio César Machado, in Ramalho Ortigão, Banhos de caldas e águas minerais, introdução. 


\section{2 - O Brasil, a Gazeta de Notícias e Ramalho Ortigão}

2.1 - A reforma eleitoral brasileira

Quando a 12 de julho de 1877, a Gazeta de Notícias publicou a primeira de uma longa série de "Cartas Portuguesas", enviada por seu mais novo colaborador, Ramalho Ortigão, faltavam ainda cinco meses para que o Partido Liberal voltasse ao poder. O primeiro gabinete que marcou o retorno dos liberais ao centro das decisões seria formado e presidido pelo senador alagoano João Lins Vieira Cansanção de Sinimbu, o visconde de Sinimbu que, para surpresa geral, recebera esta incumbência do imperador, em detrimento do senador baiano José Tomás Nabuco de Araújo, respeitado jurisconsulto, titular em três oportunidades da Pasta da Justiça e, naquele momento, a principal liderança daquele partido, a quem, tudo levava a crer, caberia a honra de formar e presidir, após quase dez anos de ostracismo, este primeiro ministério liberal.

Mas não foi isso o que se deu e Nabuco de Araújo morreria dois meses após a posse do novo gabinete, vítima de infecção biliar, causada, segundo as más línguas, pela preterição imperial. Antes, porém, quando ainda se achava vivo, ativo e livre das maledicências, assegurou, junto a Domingos de Souza Leão, o barão de Vila Bela, chefe liberal de grande projeção e autoridade na província de Pernambuco, a eleição de seu filho para a Câmara dos Deputados. E foi assim desta maneira que o jovem Joaquim Nabuco se tornou representante daquela província na câmara de 1879, uma assembléia que, além dele, teve o privilégio de contar com mais três jovens talentosos: Rui Barbosa de Oliveira, Afonso Augusto Moreira Pena e Rodolfo Epifânio de Souza Dantas, filho de Manoel Pinto de Souza Dantas, baiano, conselheiro e senador liberal. Amigo particular de Rui, com quem manteve estreito convívio em Salvador, Rodolfo era, dentre os jovens estreantes daquela assembléia, quem por natureza possuía e revelava dotes e qualidades próprios de homem público e, portanto, não foi sem razão que se constituiu em uma das maiores promessas políticas da época, infelizmente não concretizada. 
O Partido Conservador vinha se mantendo no poder desde meados de 1868 e ao ser derrubado tinha como chefe de gabinete Luís Alves de Lima e Silva - o duque de Caxias - apelidado de "penacho funesto"117 por José de Alencar, pelo fato de jamais ter passado a chefia do ministério a um correligionário de seu partido ${ }^{118}$. Mas, a despeito deste fato, com seus dois anos e meio de duração, este último gabinete de Caxias conta-se entre os mais estáveis de todo o período constitucional do império brasileiro.

Um pouco menos durou o gabinete de 5 de janeiro de 1878, o primeiro a ser organizado pelos liberais, após dez anos de ostracismo, gabinete este em que figurou o que de melhor havia no liberalismo da época, como é o caso de Lafayette Rodrigues Pereira, que embora signatário do manifesto republicano de 1870, foi chamado, primeiro, por Sinimbu para ocupar a Pasta da Justiça e, depois, por D.Pedro II para chefiar o ministério de 24 de maio de 1883; como também é o caso de Gaspar da Silveira Martins, que na fase republicana esteve envolvido na Revolução Federalista, chamado para a Pasta da Fazenda, substituído interinamente por Sinimbu e, em seguida, por Afonso Celso de Assis Figueiredo ${ }^{119}$, que presidiu o último gabinete ministerial do império brasileiro, empossado a 7 de junho de 1889 e se tornou o pivô-estopim do golpe que derrubou a monarquia.

Este primeiro gabinete liberal se agüentou no poder até fins de março de 1880 e ficou conhecido como "gabinete terremoto", devido a desentendimentos ocorridos em seu interior, quase sempre provocados pela exagerada austeridade e total intransigência de seu organizador que, autoritário e egocêntrico, acumulou vários cargos e dificultou sobremaneira a atuação de seus auxiliares.

O gabinete Sinimbu tinha como principal propósito a aprovação da reforma eleitoral que trazia em seu bojo duas questões com ela relacionadas: a eleição direta e a elegibilidade dos não-católicos. Tão acaloradas foram as discussões sobre esta reforma, monopolizando tanto as atenções, que medidas

\footnotetext{
${ }^{117}$ Luís Viana Filho, A vida de Rui Barbosa, p. 86.

${ }^{118} \mathrm{O}$ mesmo lhe havia sucedido em 1862 , quando ainda não passava de marquês.

119 Era pai do conde Afonso Celso, nascido em 1860, escritor, jornalista, autor de Oito anos no parlamento, $O$ imperador no exílio e As aventuras de Manuel João, romance publicado em folhetins pela Gazeta de Notícias no segundo semestre de 1902.
} 
outras tomadas pelo gabinete passaram a um plano secundário. É o caso, por exemplo, das que dispunham sobre a educação: criação de cursos noturnos; reforma do ensino primário e secundário (ambos na corte) e reforma do ensino superior, neste caso, não só na corte com também nas províncias.

Mas era, sem sombra de dúvida, a eleição direta a pauta principal das discussões e das negociações. Sonho acalentado pelos liberais desde 1868 quando foram apeados do poder, achava-se ela agora ao alcance das mãos e completava neste ano de 1878 seis anos que Rui Barbosa - um de seus principais artífices - estreara na tribuna popular, justamente em comício organizado para se debater esta idéia.

A reforma eleitoral era assunto seguro nas conversações políticas e havia quem afirmasse terem sido os liberais chamados ao poder pelo interesse que, veladamente, demonstrava o próprio imperador em vê-la implementada. E tanto tem fundamento esta suposição que ao cair João Lins Vieira Cansansão de Sinimbu ${ }^{120}$ D. Pedro II insistiu, chamando para substituí-lo José Antônio Saraiva, um dos poucos homens que naquele momento, devido à moral elevada e à experiência política, reunia as condições necessárias para levá-la a bom termo. Seu prestígio era tanto que foi o único político do regime monárquico a merecer o cognome de vice-imperador.

E assim que assumiu o poder, o senador Saraiva, em discurso na Câmara, apresentando o gabinete e o seu programa de governo, destacou a importância da reforma eleitoral e assegurou ser ela, de todo seu programa, a principal matéria a ser tratada e o tópico que lhe mereceria maior cuidado e atenção, dada a importância e urgência de sua implementação.

Sabe-se hoje ter sido Rui Barbosa o redator do projeto, por incumbência do senador Dantas, titular da Pasta do Império, que lhe entregou um anteprojeto rascunhado pelo próprio conselheiro Saraiva. A lei, antes de

\footnotetext{
${ }^{120}$ Seja por falta de tempo ou por incapacidade política, Sinimbu não foi capaz de implementar a reforma eleitoral, mas não foi exatamente por isso que caiu e sim em consequiência da manifestação popular conhecida por Revolta do Vintém.
} 
aprovada, ainda recebeu "sugestões e retoques do próprio punho do imperador" ${ }^{121}$.

Embora houvesse discordâncias ${ }^{122}$, o projeto passou na Câmara e no Senado, onde foi decisiva a influência do conselheiro Saraiva, como havia previsto o imperador. Promulgada em 9 de janeiro de 1881, ficou conhecida como Lei do Censo, ou Lei Saraiva.

2.2 - O sufrágio universal

Em sua correspondência para a Gazeta de Notícias, Ramalho Ortigão, muito raramente tratou das coisas do Brasil, mas isso não quer dizer que ele as desconhecesse e, sendo assim, não é de se duvidar que tenha acompanhado de perto todo o trâmite do projeto desta lei no congresso brasileiro, ele que, sabidamente, era um cético e não fazia questão alguma de esconder a sua profunda desconfiança no sufrágio universal.

Quando em carta publicada pela Gazeta de Notícias em 19 de fevereiro de 1883, comentou a primeira atuação de Manuel de Arriaga na câmara portuguesa, eleito que fora deputado republicano pelo distrito de Funchal, Ramalho Ortigão, partindo do juramento político a que eram submetidos os deputados, uma solenidade que simplesmente desqualifica, segue no mesmo diapasão e chega ao processo eletivo, dizendo o que realmente pensa das eleições gerais em Portugal.

$\mathrm{Na}$ grande maioria dos círculos eleitorais do país, continente e ilhas, todo o eleitor que não vende simples e chãmente o seu voto por dinheiro, vende-o por serviços, por bondades, ou por favores pessoais, ao pároco, ao escrivão da fazenda que cobra a

\footnotetext{
${ }^{121}$ Basílio de Magalhães, Estudos de História do Brasil, p. 63.

${ }^{122} \mathrm{O}$ deputado Saldanha Marinho, por exemplo, alegava que não poderia ser considerado sufrágio universal uma lei que, pela exigência de comprovação por parte do eleitorado de uma renda, tida por ele, como muito elevada, excluiria do processo eleitoral uma parcela considerável da população.
} 
décima ou ao agente de recrutamento que manda prender para soldado. $^{123}$

E assim como neste passo há inúmeros outros em sua obra que revelam a mesma descrença, a mesma desconfiança no sufrágio popular. Esta opinião de Ramalho face à conduta do eleitor diante das urnas, depositando seu voto quase sempre levado por interesses imediatos e não conduzido por uma ideologia política definida, como assinala este texto publicado em 1883 pela Gazeta de Notícias, não era, pois, nenhuma novidade. Era coisa velha, antiga mesmo, anterior até à publicação de As farpas, remontando aos tempos de correspondente, em Lisboa, de O Progresso do Porto, ocasião em que passou, por obrigação profissional, a freqüentar as sessões da Câmara dos Deputados e, conseqüentemente, a tratar de perto as questões políticas que envolviam seu país. Desde àquela época passou a tratar a questão, mantendose fiel a seu ponto de vista que era o mesmo de Max Nordeau, para quem o resultado das urnas não poderia jamais representar outra coisa senão a "opinião de medíocres"124.

Mas, não obstante a descrença, tinha o sufrágio universal como uma das maiores conquistas do século XIX, desconhecida de sociedades anteriores e que poderia se constituir em uma poderosa arma, havendo de figurar para sempre na história da civilização ocidental "como um dos mais belos triunfos da dignidade humana"125.

Esta aparente contradição se explica e justifica: se o que Ramalho estava fazendo, em última instância, era atribuir a responsabilidade pelo círculo vicioso que envolvia a política em Portugal ao próprio povo, tudo poderia ser resolvido com educação e esclarecimento. Um povo politicamente esclarecido, com uma posição ideológica definida a respeito dos fins do estado; um cidadão consciente de seus deveres e direitos políticos estaria plenamente apto para bem julgar e melhor escolher seus representantes e aí ninguém poderia considerar o resultado das urnas a representação da "opinião de medíocres".

\footnotetext{
${ }^{123}$ Gazeta de Notícias, 19 de fevereiro de 1883.

${ }^{124}$ Ramalho Ortigão, "Rei D. Carlos, o martirizado”, in Últimas farpas, p. 228.

${ }^{125}$ Gazeta de Notícias, 2 de janeiro de 1885.
} 
Agora, como acreditar no sufrágio universal ${ }^{126}$ quem punha em dúvida, não simplesmente a capacidade, mas principalmente a honestidade do eleitor?

Sobra de tudo isto a impressão de um tratamento superficial dado a uma questão fundamentalmente complexa, envolvendo o desenvolvimento intelectual do povo que dificilmente seria conseguido sem que se fizesse passar pelos bancos escolares, sem que lhe fosse proporcionada uma boa educação pública, reconhecidamente deficiente naquela época em Portugal.

Mas o comprometimento do eleitorado não era privilégio apenas daquele país. O mesmo se dava também no Brasil, conforme relata Joaquim Nabuco em Minha formação. Certo dia, achando-se em uma campanha eleitoral, peregrinava, ele, por um bairro pobre do Recife, batendo de porta em porta, conversando com os eleitores, cabulando o voto, enfim, quando deparou com um sujeito - o Jararaca - que embora muito o admirasse, vivia um grande embaraço pois havia recebido do chefe político local a cédula marcada com o nome do candidato a ser votado. Mas, ainda assim, estava disposto a votar por ele, sob pena de perder o emprego e o sustento dos filhos. Era só ele pedir. Mas faltou a Joaquim Nabuco a coragem para tanto e foi justamente o contrário o que lhe pediu; que levasse a cédula recebida, votasse com o governo e não afrontasse seu protetor. E ao sair, temendo pela recusa de seus conselhos, empenha-se com a mulher: não permitisse de forma alguma ao marido votar por ele.

Se eram semelhantes em sua prática eleitoral, mais ainda se assemelhavam em sua estrutura formal os dois sistemas representativos, o que não é para causar estranheza já que se tratavam de instituições nascidas praticamente numa mesma época e quase que sob os auspícios dos mesmos ideólogos. E, sem contestação, representaram indiscutivelmente um grande avanço político no aprimoramento de suas instituições e uma significativa conquista para a dignidade humana, em nome da qual os liberais brasileiros de 1880 empreenderam uma verdadeira cruzada na luta pela implantação das

\footnotetext{
${ }^{126}$ Respondendo a um inquérito sobre o assunto promovido pelo jornal $O$ Tempo de Carlos Lobo de Ávila, Ramalho, entre outras coisas, diz o seguinte: "Dentro do campo das ficções - e é esse campo que constitui o domínio de toda a política moderna - o sufrágio popular entendo que é a superstiçãozinha mais catita que aí temos". (Ramalho Ortigão, Folhas soltas, p. 190)
} 
eleições diretas. Embora seja esta uma conquista a ser compartilhada, a ela estão incontestavelmente vinculados os nomes de Sinimbu, Dantas, Rui Barbosa e acima de todos o de José Antonio Saraiva.

\section{3 - O gabinete Saraiva}

Empossado em 28 de março de 1880, quase dois anos durou o primeiro gabinete chefiado por Saraiva, que teve oportunidade de organizar um outro, em 6 de maio de 1885, curtíssimo este, porém, que nem chegou a completar três meses e meio de duração.

Quase que só de deputados foi formado o primeiro gabinete ministerial do conselheiro Saraiva. Seriam exceções o marechal José Antônio Correia da Câmara, titular do Ministério da Guerra e o senador Manoel Pinto de Souza Dantas, que ocupou a Pasta da Justiça.

Aliás, este ocupante da Pasta da Justiça era o mesmo Manuel Pinto de Souza Dantas que, nos tempos de vida pública na província da Bahia, foi correligionário e amigo particular de João Barbosa, pai de Rui. Percebendo no rapaz franzino um privilegiado do talento, prognosticou-lhe um futuro brilhante e ao notar as dificuldades financeiras por que passava o pai, resolveu ajudar o filho.

Louvado é sempre o espírito de solidariedade e companheirismo do conselheiro Dantas, líder da ala do Partido Liberal mais identificada com a causa abolicionista, um homem simples e simpático que era, sobretudo, dotado de uma excepcional capacidade de intuir virtudes e defeitos daqueles com os quais convivia. "Através da aparência de um homem fútil, assíduo a missas, enterros e batizados, havia um sagaz conhecedor de almas..."127

\footnotetext{
${ }^{127}$ Correspondência de Rodolfo E. de Souza Dantas, p. 9. Os homens de espírito que o conheceram, se divertiam dizendo que ele não dispensava a gravata e o terno preto para assim estar sempre pronto a acompanhar o enterro de qualquer infeliz que o destino lhe pusesse no caminho.
} 
Bom formador de equipes, Dantas levou inicialmente Rui para seu escritório de advocacia e, logo a seguir, para a redação do Diário da Bahia, periódico por ele dirigido e transformado em reduto dos liberais baianos. E foi ainda mais além, abrindo-Ihe a porta da casa, que Rui passou a freqüentar. Em bem pouco tempo o rapaz tornou-se íntimo da família, florescendo entre ele e Rodolfo, segundo filho do conselheiro, uma estreita e cordial amizade que, principiada na província da Bahia transferiu-se para a corte do Rio de Janeiro e só foi arrefecida com a proclamação da república ${ }^{128}$, a ruptura política que os colocou em lados opostos: Rodolfo manteve-se para sempre fiel à monarquia, enquanto Rui transformou-se em um dos principais artífices da nova ordem constituída.

Mas enquanto durou a estreita amizade, foram constantes os contatos e os compromissos, da mesma forma como foi mútua e contínua a correspondência entre eles. Naqueles tempos em que não se podia contar com o auxílio do telefone para os contatos corriqueiros, tornavam-se socialmente imprescindíveis os serviços de um portador, função que no Brasil geralmente era exercida por escravos de confiança, incumbidos de levarem as encomendas, as cartas, os bilhetes, os recados e, muitas vezes, aguardarem as respostas. Qual uma verdadeira rede de correio ambulante, há uma infinidade destes portadores nas obras dos prosadores da época. Machado de Assis é um exemplo, em meio a tantos outros. Na correspondência entre Rodolfo e Rui, é notória esta forma de comunicação e relacionamento, com estafetas correndo de um lado para outro, levando e trazendo recados, respostas, revistas, jornais, livros e outros objetos. Sirva de exemplo esta resposta a um pedido de Rui, enviada por Rodolfo em fevereiro de 1878, tempos em que ainda se achavam na Bahia: "Infelizmente não está aqui em casa nenhum dos livros que pedes: procurei-os por toda parte, e os não encontrei" ${ }^{129}$.

\footnotetext{
${ }^{128}$ A quebra de confiança que representou a conduta de Rui neste episódio deixou completamente desconsertados os Dantas - pai e filho - que só vieram a conhecer o comprometimento político do velho amigo e correligionário quando tudo já se havia consumado.

${ }^{129}$ Correspondencia de Rodolfo E. de Souza Dantas, p. 24.
} 
Muito provavelmente, os livros, caríssimos na época, andavam tanto de mão em mão que Rui já não era mais capaz de saber ao certo o lugar onde eles se encontravam.

Um pouco antes deste pedido de Rui, ainda no princípio do mês de janeiro, Rodolfo, em um desses bilhetes trocados, leva ao conhecimento do amigo um fato que seria decisivo para os novos rumos que deveria tomar a vida de ambos: havia há pouco recebido do Rio de Janeiro um telegrama comunicando a chamada ao paço de São Cristóvão do visconde de Sinimbu. Era um evidente sinal de que estava prestes a chegar ao fim a angustiante espera dos liberais, afastados do poder desde julho de 1868, quando caiu 0 gabinete do senador Zacarias de Góis.

E como não eram simples sinais de fumaça, realmente, os liberais assumiram o poder com o visconde de Sinimbu chefiando o gabinete e pouco tempo depois a Câmara, de maioria conservadora, era dissolvida pelo imperador, sendo convocada outra para se reunir a 15 de dezembro de 1878. Isto significava nova eleição em todo o país e foi dela que saíram vencedores uma verdadeira fornada de jovens políticos de talento: Rui Barbosa, Joaquim Nabuco, Afonso Pena, entre eles, ficando Rodolfo Dantas com uma vaga de suplente de deputado.

Em conseqüência desse resultado, pelos fins deste ano de 1878, Rui embarcou para o Rio de Janeiro a fim de receber o seu diploma e ocupar, na câmara baixa, a cadeira de deputado para a qual os baianos o haviam indicado. Logo no início do ano seguinte, seguiu Rodolfo o mesmo destino, chamado para ocupar, na qualidade de deputado suplente, a vaga deixada pelo pai que havia sido nomeado pelo imperador para o posto mais cobiçado pelos políticos do império: a chamada câmara alta, o Senado, de mandato vitalício.

No Rio de Janeiro, o intercâmbio cultural e a correspondência, comuns na Bahia, continuaram. Mas agora com seu círculo ampliado, como se vê por este trecho da carta de Rodolfo endereçado a Rui, em 9 abril de 1879: "Envio-te o Macleod. Quanto ao Beaulieu, o Joaquim Nabuco pediu-me 
emprestado há dois ou três dias e inda mo não restituiu"130. Henry Macleod e Paul Leroy-Beaulieu eram dois conceituados economistas da época, muito citados, autores de obras que eram obviamente objetos de consulta de jovens estudiosos. A referência a eles feita nesta pequena passagem de uma carta cujo assunto principal era a interpelação apresentada um dia antes por Gaspar da Silveira Martins ao gabinete Sinimbu revela de maneira insofismável que a economia era também assunto de interesse de Rui. Isto tem alguma importância quando se sabe ter sido ele o primeiro ministro da fazenda no governo da república, cuja gestão, muito criticada e pouco refletida, resultou no episódio conhecido como "Encilhamento".

Mas, além dos compêndios de economia, os dois amigos trocavam também obras de direito, livros de história, revistas, discursos, pareceres, entre outras coisas. Particularmente para este trabalho, foi por demais sugestivo o pedido de Rodolfo a Rui, feito no post-scriptum da carta datada de 12 de junho de 1879: "Manda-me pelo portador o teu volume das Notas de viagem, de Ramalho Ortigão: não encontro aqui o meu exemplar" ${ }^{131}$.

Há certas particularidades neste pedido de empréstimo que vale a pena destacar: primeiro, não se trata mais de livro técnico, como nos outros casos; segundo, Rodolfo fala em "teu volume" e "meu exemplar", sugerindo com isso que cada um possuía o seu, o que não era comum; terceiro, revela de maneira significativa para este estudo que aqueles dois jovens deputados eram realmente leitores de Ramalho Ortigão. Resta agora saber do que tratavam estas Notas de viagem e o porquê do interesse de Rui Barbosa e Rodolfo Dantas por este livro do escritor português.

\section{4 - As Notas de viagem de Ramalho Ortigão}

Notas de viagem é o título de um livro de Ramalho Ortigão, publicado em 1879, resultado da recolha de uma série de dezenove artigos

\footnotetext{
${ }^{130}$ Ibidem, p. 41.

${ }^{131}$ Ibidem, p. 43.
} 
publicados na Gazeta de Notícias entre fins de 1878 e princípios do ano seguinte. Eram, na verdade, uma série de cartas enviadas de Paris, onde o autor se achava - ao que tudo indica comissionado pelo jornal - para comentar a Exposição Universal promovida por aquela cidade, um evento marcante que se constituía na época em verdadeiro acontecimento para a indústria, o comércio e a arte.

Da carta explicativa ao editor da Gazeta de Notícias, texto que serve de prefácio, presume-se ter partido a proposta de recolha e edição em livro do material do próprio jornal. Eram comuns na época os seguintes passos: publicavam-se os textos primeiramente em folhetins na imprensa e, em seguida, recolhia-se este material e editava-se um livro. Há uma série de casos exemplificando este procedimento. Recorde-se, por exemplo, como foi a proposta de Ramalho Ortigão feita a $O$ Jornal do Porto para a publicação da obra Jerusalém e o Cairo de Eça de Queirós, comentado anteriormente. É, aliás, quase sempre lembrado que esta prática serviu de base para reclamação de muitos romancistas que viam antecipada, sem que houvessem antes firmado contrato, a publicação em volume de romances que mal haviam sido concluídos nos folhetins do jornal.

Não é o caso, porém, desta obra de Ramalho Ortigão, cujo processo de editoração seguiu os trâmites legais e se pautou pelos procedimentos éticos que, ordinariamente, deveriam nortear este tipo de transação comercial. Ao pedido do editor correspondeu um assentimento do autor, tornado público na carta em forma de prefácio - oportunidade aproveitada para, modestamente, lamentar as falhas de um trabalho que, a seu modo de ver, faltavam, "além de outros elementos, a contigüidade e a conexão que constituem o caráter de um livro"132.

Estruturalmente, as Notas de viagem ${ }^{133}$, que tem por subtítulo "Paris e a Exposição Universal (1878 - 1879)", podem ser divididas em dois grandes blocos, com praticamente as mesmas proporções: o primeiro deles,

\footnotetext{
${ }^{132}$ Ramalho Ortigão, Notas de viagem, p. 6.

${ }^{133}$ Como se sabe, a seção da Gazeta de Notícias em que se publicavam as colaborações de Ramalho Ortigão era costumeiramente denominada "Cartas Portuguesas", e assim vinham sendo elas chamadas até a partida do escritor para a França quando, então, passaram a ser publicadas em uma nova seção denominada "Notas de viagem", nome que será aproveitado para o título do livro. No entanto, logo após o encerramento da remessa dos folhetins enviados de Paris, a seção retoma sua antiga denominação.
} 
composto de oito cartas, trata principalmente dos aspectos da cidade e de seus habitantes. Com exceção da terceira, intitulada "Alguns sucessos", todas as demais são identificadas apenas pelas datas de envio ao jornal. O segundo bloco, formado pelas onze cartas restantes, trata especificamente da Exposição Universal. Todas elas são intituladas e em nenhuma é consignada a data de envio.

A carta que abre o livro e dá início ao primeiro bloco, datada de 8 de julho e publicada na Gazeta de Notícias a 17 de agosto de 1878, é toda ela dedicada às mulheres de Paris, desde a jovem sem compromisso até a burguesa bem casada que, para o autor, era a mais honesta entre todas as mulheres. Erram grosseiramente, dizia Ramalho, aqueles que - à maneira dos "viajantes chegados de remotos países quase selvagens"134 - a priori e por hipótese julgam ser toda parisiense uma cocotte desfrutável. Parecia até um alerta àqueles que sonhavam com facilidades, sonhos evidentemente estimulados pela provocante descrição que o folhetinista fazia da parisiense, pintada com riqueza de detalhes, fruto, ou de um agudo senso de observação, qualidade a ele atribuída por todos os comentadores de sua obra, ou então fruto de muita imaginação criativa, que nunca foi realmente seu forte. Seja lá como for, é uma descrição voluptuosa, estimulante e detalhada da mulher de Paris, contemplada em seu vulto, seguida em seus passos, ouvida em sua própria voz; quando não: espiada, intuída, adivinhada.

A parisiense é a primeira das especialidades de Paris. Com o seu narizinho ligeiramente arrebitado, atrevido e alegre; com o olhar fino e penetrante; a boca um tanto grossa, um tanto grande, vigorosamente desenhada em forma de flecha como convém à articulação de uma linguagem nítida e vibrante; os pés mais volumosos do que exíguos; o ar determinado, dominativo, satisfeito; o passo alto, miudinho e firme, fazendo tique-tique sobre o asfalto; com a sua característica fisionomia enfim, com o seu vestido bem apanhado do chão, as suas compras bem acondicionadas debaixo de cada braço, a parisiense comove muito mais o estrangeiro do que o

\footnotetext{
${ }^{134}$ Ramalho Ortigão, op. cit., p. 8.
} 
zimbório dos Inválidos, a coluna da praça Vendôme, o arco da Estrela ou qualquer outro dos grandes monumentos da bela capital. ${ }^{135}$

Imagina-se o quanto de sonho e fantasia passagens como essas não seriam capazes de produzir em um sóbrio e pacato leitor brasileiro, separado por todo um oceano daquele paraíso alegre e descontraído em que a lascívia, representada pelos cabarés onde se dançava o cancã, imperava, espalhando-se por toda a cidade, desde a Ópera até o Bois de Boulogne, o belo bosque, onde era dado pela manhã ver cavalgarem as mais finas e elegantes mademoiselles de Paris.

No entanto, Ramalho não se atém apenas ao aspecto frívolo feminino da parisiense, contrapondo a ele seu lado prático de mulher ativa e enérgica, firme e diligente, capaz de surpreender e revelar, por este lado, uma fiel e zelosa colaboradora. E era isto o que via caracterizado por seu real interesse em participar ativamente da vida econômica da cidade, uma verdadeira metrópole cujo espírito empreendedor se revelava, como em nenhum outro lugar, pela intensa atividade comercial, industrial e artística. E mais que qualquer coisa, era esse dinamismo de Paris que sobremaneira influenciava e convertia mulheres de outras regiões que para ali se transladavam. Cita o exemplo de uma senhora baiana, tida e havida por ele como uma mulher totalmente transformada e perfeitamente adaptada ao jeito de ser da autêntica parisiense. Embora ainda preso ao determinismo do meio, não escapando ao preconceito da influência do clima tropical sobre o ânimo e a disposição das pessoas, surpreende-se ao deparar com uma elegante mulher, ativa, inteligente e ao mesmo tempo esposa e secretária que rigorosamente escriturava os livros, redigia a correspondência, organizava os arquivos, participando assim ativamente dos negócios do marido, um bem sucedido empresário que se, por ventura, fosse obrigado a se afastar, poderia sem susto deixar em suas mãos a condução dos negócios da família.

Pouco mais de um mês depois desta primeira carta, louvando a diligência e a participação da mulher parisiense na vida pública da cidade, chega uma nova carta, desta vez, comentando o congresso que as mulheres

\footnotetext{
${ }^{135}$ Ibidem, pp. 7, 8.
} 
haviam realizado na intenção de "definir os seus direitos com relação aos direitos dos homens"136. Aí então muda tudo e se manifestam as contradições. Muito outro se revela agora o pensamento de Ramalho Ortigão a respeito das mulheres e o lugar que deveriam ocupar naquela sociedade. Evidentemente que hoje, diante de tanta conquista, após tanta luta e sucessivos congressos, já não mais seja tão simples encontrar quem apóie e dê respaldo a tais juízos. Mas, naquela época, aos fins do século XIX e pelo que se depreende do texto, pareciam algo assente e estabelecido, permitindo supor que fossem naturalmente acatados pela grande maioria dos leitores e até mesmo das leitoras. Não era a indignação diante da desigualdade que caracterizava o relacionamento entre os dois sexos, tanto que Ramalho estava convencido de que o acordo conjugal tinha por base justamente esta desigualdade. Era a mulher um complemento indispensável ao homem, justamente por ser diferente dele e representar o lado frágil da união. "É da sua fraqueza que ela tira a meiguice, a graça, a delicadeza, o mimo, a ternura, o carinho"137.

E sendo assim, cometeria erro grosseiro quem propusesse, como acontecia nas reuniões daquele congresso, fazer das mulheres entes iguais aos homens. O seu lugar na sociedade já havia sido previamente definido e o seu destino traçado. Querer mudá-lo e torná-las seres iguais aos homens seria o mesmo que atrofiá-las, pondo a perder as reais qualidades que as caracterizavam, distinguiam e faziam delas perfeitos complementos conjugais.

A grande, a elevada, a importante função da mulher na sociedade humana não é ser telegrafista, ser boticária, ser jornalista ou ser doutora; é ser mãe e é ser esposa. ${ }^{138}$

$E$ todos os conhecimentos que acaso adquirissem justificavam-se desde que se aplicassem no melhor desempenho destas funções. Acreditava ele que para bem cumprir o "sublime" papel social de mãe e esposa a mulher dependeria, não só de sua própria aptidão natural, mas também de um razoável acervo de conhecimentos: "um largo e aturado estudo"139.

\footnotetext{
136 Ibidem, p. 69.

${ }^{137}$ Ibidem, p. 70.

${ }^{138}$ Ibidem, p. 73.

${ }^{139}$ Ibidem, p. 73 .
} 
E dois eram os principais tópicos destes estudos - a química e a fisiologia. Valioso seria o conhecimento destas ciências para as mulheres no momento de escolher e organizar um cardápio convenientemente adequado às etapas da vida e do desenvolvimento de seus filhos.

Uma pequena porção de alimento a mais ou a menos do que pode suportar o estômago de uma criança compromete a saúde do homem para toda a vida; a qualidade do alimento determina a futura feição do caráter. Isto não é uma pura hipótese, não é uma fórmula literária, é uma verdade científica; e não obstante - enorme infortúnio - são raríssimas as mães que não ignoram como devem dar de comer ao seu filho. ${ }^{140}$

É necessário, porém, frisar, repetindo, que a instrução feminina teria exclusivamente um fim: preparar, dispor e habilitar as mulheres para bem desempenharem seu papel na sociedade, na qualidade de mãe e esposa. Para isto, sim, elas deveriam ser devidamente educadas; jamais, porém, para questionarem os códigos de direito penal e de direito civil, tampouco para discutirem o adultério, a prostituição e outros assuntos constantes da pauta dos debates no Congresso das Mulheres, um congresso que não teve do público, principalmente feminino, o merecido apoio e a devida atenção.

Pode parecer tendenciosa e era realmente a posição de Ramalho perante o Congresso das Mulheres, mas para a análise crítica de seu pensamento - ele que era um jornalista importante e seguramente um grande formador de opinião - é preciso se levar em conta um conceito generalizado hoje em dia, qual seja o de incorrer em erro quem julga um indivíduo isolando-o de seu meio e de seu momento histórico, conferindo-Ihe um tratamento diferenciado como se ele não estivesse sujeito, nem sofresse influências do meio e do modo de ser e de pensar próprios de seu tempo. Esta lição da antropologia cultural, tão largamente difundida, deve ser aqui devidamente observada e levada em consideração, uma vez que o próprio autor chega a solicitar a cumplicidade de suas leitoras para seus pontos de vista. E não se

\footnotetext{
${ }^{140}$ Ibidem, pp. 73, 74.
} 
pense que através de subterfúgios ou figuras de retórica; nada disso, tudo lavrado em linguagem simples e chã.

Mas a lição precisa ser observada para que não se tornem risíveis, aos olhos de hoje, as opiniões de Ramalho a respeito da instrução feminina. Quando delas se toma conhecimento e, mais, do lugar destinado às mulheres naquela sociedade é que se vê o quanto se conquistou neste curto período de pouco mais de um século, diante do longo período de total submissão.

Antes de passar aos comentários das cartas que tratam propriamente da Exposição Universal - aquelas que, como já foi frisado, constituem a segunda parte destas Notas de viagem - valeria ainda a pena comentar duas outras deste bloco que abre o livro.

$\mathrm{Na}$ primeira delas - a única, nesse conjunto, sem data e com título: "Alguns sucessos" - Ramalho noticia a morte de Antonio Augusto Teixeira de Vasconcelos, o escritor português que ao fim da vida, em companhia de um sobrinho e contrariando recomendação médica, atravessou os Pirineus para ir morrer em Paris.

Após acompanhar o corpo do amigo ao cemitério de Montmartre, Ramalho esboça-lhe um pequeno perfil, destacando a natureza dual de sua personalidade: de um lado o escritor, homem público, e de outro o homem comum, o ser social que freqüentava os cafés e conversava com os amigos. Não demonstrando pelo escritor, cuja obra considerava insincera, o mesmo interesse que nutria pelo homem comum, Ramalho ressalta um traço marcante da personalidade de Teixeira de Vasconcelos. Trata-se do caráter prosista e gracejador, da sua feição especial de conversador irônico e vivaz. Esse aspecto particular de sua personalidade, que era também de outros artistas, será tratado oportunamente, ocasião em que se comentará o relevo dado pelos contemporâneos - à capacidade de expressão oral, à beleza, interesse e expressividade de certos escritores na conversação descontraída do dia-a-dia, caso típico, entre os brasileiros, de Francisco de Paula Nei, hoje muito mais lembrado e valorizado pelos ditos e pilhérias com que divertia os amigos nas 
mesas dos cafés, do que propriamente pelos trabalhos que deixou espalhados pelos jornais da época.

Prometendo aos leitores da Gazeta de Notícias, para o futuro, um "largo estudo" da personalidade literária de Teixeira de Vasconcelos, Ramalho Ortigão, nesta nota de viagem, apenas aproveita para comentar em ligeiros traços a obra daquele amigo particular que acabava de deixar em um cemitério de Paris, conferindo especial relevo ao homem de espírito, ao indivíduo de inteligência viva e engenhosa, sutil e espirituosa.

Na conversação particular, no círculo estreito dos seus íntimos, quando ele consentia em deixar passar aquela metade do seu ser, a que poderíamos chamar o Antonio Augusto, para diante da outra metade formada pelo conselheiro Teixeira de Vasconcelos, então esse homem tomava as proporções mais extraordinárias e mais assombrosas (...) A sua palavra desfibrava um homem a nervo por nervo, como um escalpelo. Os seus epigramas eram amassados em nitroglicerina. Tinha ditos carregados com substâncias mais explosivas do que a dinamite. Um desses ditos caía sobre uma reputação, como atirado ao acaso, depois rebentava com um estampido enorme, e a reputação submetida a essa descarga ia pelos ares, esfarrapada, dispersa, desfeita em estilhas. Esse imenso poder, que constituía a grande e legítima superioridade de Teixeira de Vasconcelos, não quis ele nunca exercê-la em uma obra de arte; deixou assim de publicar o livro destinado a imortalizá-lo. ${ }^{141}$

Quanto à segunda carta deste bloco, sem título e apenas datada de 30 de julho, vale a pena ser destacada pela referência que faz a uma entrevista concedida por Victor Hugo ao imperador D. Pedro II: um preito que a realeza brasileira - na pessoa de seu representante máximo - fazia questão de prestar a um dos maiores símbolos da democracia francesa. $O$ encontro se deu na própria casa do poeta, já que havia recusado o convite para uma entrevista com D. Pedro II, a ele dirigido pela embaixada brasileira em Paris.

\footnotetext{
${ }^{141}$ Ibidem, pp. 33, 34.
} 
Diante da recusa, acrescida do adiamento, por razões imprevistas, de um encontro entre eles em um gabinete do senado francês, o imperador brasileiro decidiu, ele próprio, bater à porta do poeta. Já que Maomé não concedia a honra de ir até a montanha...

Ramalho revela ao leitor brasileiro alguns pormenores deste encontro, curiosidades reproduzidas de memória sobre a leitura de um jornal francês que havia publicado um longo trecho de um capítulo do livro intitulado Victor Hugo chez lui, do qual infelizmente não registra a autoria.

O que realmente é curioso, interessante e sobremodo chama a atenção nesta carta de 30 de julho de 1878 é a maneira simpática e respeitosa como é tratada a pessoa do imperador D. Pedro II, muito diferente daquele tratamento zombeteiro que As farpas a ele havia dispensado em sua passagem por Portugal, no princípio desta mesma década.

Claro está que esta atitude era precisa e ajustada à nova realidade vivida pelo escritor. A fase áurea, mais produtiva e de grande interesse despertado por As farpas, conhecia seus declínios, tanto quanto o velho espírito de fundibulário iconoclasta. Uma nova perspectiva se abria do outro lado do Atlântico e Ramalho, com uma reputação firmada, um estilo próprio e mais de vinte anos de experiência, conhecia como poucos o papel a ser representado. $O$ jornal que o havia contratado, embora ainda muito novo, era sólido em suas estruturas e, acima de tudo, generoso com seus colaboradores. Tudo contribuía para que o casamento, sob a proteção divina da língua e da literatura, fosse, além de muito feliz, duradouro e produtivo, como pode facilmente constatar quem se der ao trabalho de percorrer as páginas da Gazeta de Notícias entre os anos de 1877 a 1915.

\section{5 - A exposição de Paris em 1878}

Esta exposição foi o motivo principal da viagem e, por isto mesmo, o principal assunto, ocupando quase dois terços do total de páginas 
destas Notas de viagem. Ramalho, empenhado em dar uma idéia geral do evento a seus leitores, percorre todos os pavilhões expositores, tanto aqueles encontrados no Trocadéro ou no Campo de Marte como os seus anexos. E foi justamente em um dos anexos que o Brasil, à falta de expositores próprios, se fez representar pelo comércio do Havre, que ali expôs alguns tipos de cafés colhidos e enviados a Paris por uma associação de lavradores paulistas.

De tudo que lhe chamava a atenção e era objeto de seu interesse procurava dar uma idéia a seus leitores: fosse a adubação química, uma novidade que surgia, ou os novos processos de criação de aves, fosse a qualidade dos vinhos ou a ferraria artística, responsável pela introdução de novos metais na fabricação dos objetos, fosse ainda o mobiliário antigo, representativo de todas as épocas e de todos os estilos (bancos do século XV, espaldares do século XVI) sem, no entanto, deixar de lado ou menosprezar a mobília futura, de maior praticidade e por isto mesmo mais compatível com um novo estilo de vida.

Porém, de tudo o que se falou ou foi exposto naquele evento, dois assuntos particularmente chamaram a sua atenção, merecendo dele um maior desenvolvimento e mais espaço no livro: a educação e a arte. Tanto um como outro desses temas figuravam há tempos na agenda de interesses de Ramalho Ortigão. Educador ele foi, no princípio da vida no Colégio Nossa Senhora da Lapa, ainda antes de ingressar no jornalismo e de se dedicar à crítica de artes plásticas, tema que ocupa parte substancial de sua obra. Além dos textos que tratam do assunto e se acham espalhados por revistas e jornais da época, ainda inéditos em livro, que sirva de exemplo a Arte portuguesa, obra editada em três tomos pela Livraria Clássica Editora, tratando todos eles de aspectos inerentes à arte e aos artistas plásticos portugueses: a reforma do ensino do desenho, a pintura moderna em Lisboa, a escultura portuguesa da Renascença, as paisagens de Silva Porto, os retratos de Rafael Bordalo Pinheiro e a pintura de José Malhoa, entre outros.

Conhecedor da cidade e seus mistérios, Ramalho freqüenta, em Paris, não só o Campo de Marte e o Palácio das Indústrias, onde se encontravam as obras oficialmente catalogadas pela Exposição Universal, como também as galerias da Rua Lepelletier, onde se expunham os trabalhos 
de Delacroix, Courbet, Millet, Corot, que não poderiam ser devidamente apreciados nos pavilhões da exposição, ou porque lá não figuravam, ou porque não se achavam suficientemente bem representados.

Garante o correspondente do diário brasileiro que havia mais de seis mil e quinhentas telas francesas expostas nos salões oficiais e nas galerias da Rua Lepelletier. Reparem bem que esta cifra só dizia respeito à França. Havia ainda a Inglaterra, representada na exposição por mais de setecentos trabalhos, a Bélgica por mais de trezentos, a Itália por mais de duzentos, a Rússia por cento e cinqüenta e seis, a Espanha por cento e vinte e sete, a Holanda por cento e treze, a Hungria por sessenta e nove, a Noruega por cinqüenta e nove e Portugal por dezoito, trabalhos estes que ainda se somavam a de outros países.

Temos nove mil e setenta e um quadros, sem contar a exposição de Goupil, a de assuntos militares na Rua Vivienne, e muitas outras que se renovam quotidianamente em casa do grande número de negociantes de quadros que tem Paris. ${ }^{142}$

$E$ isto sem falar de uma nova tendência que surgia com o incipiente movimento dos impressionistas, pintores cuja corrente estética não se achava representada em nenhuma exposição pública, mas que Ramalho, atento e atualizado, constata e se dá conta de sua importância, alertando os leitores da Gazeta de Notícias para o papel a ela reservado como "encaminhadora da arte para o futuro" ${ }^{143}$. Revelando perfeita compreensão dos propósitos do movimento, mantém o espírito livre e aberto para a inovadora forma de representar a natureza e os objetos, o que não deixa de ser louvável, pois se vivia ainda a época em que os impressionistas eram considerados pelo grande público e por muitos críticos "como os comunistas, como os petroleiros da arte" ${ }^{144}$.

A arte e a educação figuram no livro, cada qual, com três capítulos. No que denominou "A exposição de pinturas" comenta e analisa os quadros e os artistas mais significativos da pintura francesa, enquanto que

\footnotetext{
142 Ibidem, pp. 119, 120.

${ }^{143}$ Ibidem, p. 152.

${ }^{144}$ Ibidem, p. 145
} 
naquele que intitulou "As nações artísticas", traça um grande painel das obras expostas pelos outros países, com especial destaque para a pintura da Espanha, da Itália, da Alemanha, da Inglaterra e da Rússia.

Admirável em Ramalho Ortigão era a versatilidade, a capacidade de falar sobre vários assuntos e persuadir com razões e argumentos e, também, a atenção e o interesse com que acompanhava a história de seu tempo, o que se evidencia no comentário ao quadro Os rebocadores, de Repine, uma das obras constantes da exposição russa. Veja se não se achava a par do que ocorria na Rússia czarista pela descrição e o comentário final que faz da tela?

Os Rebocadores, de Repine, onze trabalhadores que puxam à sirga na praia um navio que se vê a distância, são a viva imagem da plebe bestial e miserável. Cobertos de andrajos, com o olhar apagado, as fisionomias estúpidas, uma correia atravessada no peito, puxam, retesando a sirga como um tirante, com a espinha curva, dobrados, quase com as mãos na areia. São os servos. Do centro dessa récua, quase prostrada pelo cansaço, empina-se um homem soberbo de rins de aço, com o cachimbo ao canto da boca, toucado com um barrete encarnado. É a "Jovem Rússia”, que protesta, que conspira, que traz escondido por baixo da camisa, na sordidez da pele, junto do coração, o punhal que assassina a polícia. Este quadro é uma terrível página de história, é um depoimento formal e terminante contra a autocracia russa. $^{145}$

"Este quadro é uma terrível página de história", a verdadeira história de um grupo de jovens idealistas e determinados que deu início a uma luta surda, heróica e destemida, cujo desfecho, trinta e nove anos depois deste vaticínio, varreu do cenário político europeu a autocracia czarista.

Além das artes plásticas, ou mais precisamente da pintura, a educação também mereceu três capítulos nestas Notas de Viagem. A questão educacional foi preocupação constante na vida de Ramalho, fosse ela a

\footnotetext{
${ }^{145}$ Ibidem, pp. 166, 167. Ainda inéditas em livro, há quatro belíssimas cartas enviadas à Gazeta de Notícias, nos dias 24 de novembro, 2, 4 e 8 de dezembro de 1882, relativas a este mesmo tema.
} 
educação familiar (filhos e netos), revelada pela sua correspondência, fosse ela a instrução pública, revelada em vários passos de sua obra, servindo de exemplos, o texto intitulado "Os nossos filhos - instrução pública", constante do volume VIII de As farpas e "A instrução secundária na Câmara dos Deputados", publicado pela Gazeta de Notícias nos dias 23, 25, 28, 30 de abril e 2 de maio de 1883, posteriormente recolhido no volume XI de As farpas. Sendo assim, não surpreende o fato de enviar ao diário brasileiro nada menos que três folhetins cuidando do assunto: "O ensino", "O Museu Pedagógico" e "Kindergarden", como foram intitulados no livro.

No primeiro deles destaca o avanço experimentado pela instrução pública no governo republicano francês, com um aumento considerável do número de alunos nas escolas, a melhoria de suas instalações, a revisão dos métodos de ensino, a instalação de bibliotecas e a organização, a cargo de professores e alunos, de museus escolares destinados a facilitar a aquisição de conhecimentos positivos que estimulassem futuras profissionalizações.

No segundo explica o que vem a ser o Museu Pedagógico, a criação russa de uma instituição magna, garantida pelo governo e destinada exclusivamente ao amparo e auxílio da atividade escolar. Seria assim uma espécie de estabelecimento público onde as escolas poderiam se prover de todas as noções e de todos os recursos pedagógicos necessários ao bom desempenho de sua função, tendo, além disso, a capacidade de fornecer aos fundadores de novas escolas, desde o anteprojeto do prédio, passando pela sua construção até simples objetos de uso diário dos alunos, como "os tinteiros e as penas" ${ }^{146}$.

No último descreve o funcionamento dos Kinder-garden, os jardins de infância criados na Alemanha pelo pedagogo Froebel e que se haviam espalhado por toda a Europa, à exceção de Portugal, o que ele lamenta, condenando a indiferença e o desinteresse com que em seu país era tratada a educação infantil.

\footnotetext{
${ }^{146}$ Ibidem, p. 231.
} 
É isto, em linhas gerais, o que são as Notas de viagem enviadas de Paris à Gazeta de Notícias, por Ramalho Ortigão, no segundo semestre de 1878.

\section{6 - A instrução pública e Rodolfo Dantas}

Resta agora saber qual assunto estaria interessando tanto a Rodolfo Dantas que à falta de seu exemplar teria solicitado o de Rui Barbosa. Seria o mundanismo do capítulo sobre a parisiense, seriam os folhetins sobre a exposição de pintura ou as novidades apresentadas por Ramalho nos textos sobre a instrução pública? Talvez os três assuntos, com destaque, porém, para este último, já que nunca escondeu e sempre foi público o seu interesse pela educação.

Quando em 1891, Joaquim Nabuco aceitou o convite para integrar o corpo de redatores do recém-fundado Jornal do Brasil, escreveu um artigo de apresentação intitulado "Um perfil de jornal", em que o perfil destacado em seu comentário, mais do que propriamente do jornal, foi o de seu fundador: Rodolfo Dantas.

Entre outros aspectos de seu caráter apontados por Joaquim Nabuco é particularmente relevante o que diz respeito ao seu interesse pela instrução pública, que vinha desde os tempos em que fez parte do ministério organizado por Martinho Campos.

O espírito de Rodolfo Dantas tinha gravitado em política, desde as suas primeiras manifestações, para a educação nacional. Ele foi um dos que melhor compreenderam o dilema do Brasil, de resolver esse problema ou desaparecer. ${ }^{147}$

E nunca esta sua preocupação com a educação nacional foi tão manifesta como nos tempos em que esteve à frente da Pasta do Império, de

\footnotetext{
${ }^{147}$ Joaquim Nabuco, “Um perfil de jornal”, in Escritos e discursos literários, p. 80.
} 
janeiro a junho de 1882. Sabe-se que desde a reorganização ministerial realizada quarenta anos antes, ficaram ao encargo desta pasta, além dos negócios da Casa Imperial, a questão dos estabelecimentos de beneficência e socorros, a saúde e a instrução pública.

Dentre todos estes encargos, Rodolfo priorizou justamente o último e, para o melhor desempenho e andamento dos trabalhos nesta área, pediu a colaboração de Rui Barbosa. Ambos eram interessados nas reformas do ensino e, pelo que deixa transparecer na correspondência, Rodolfo parecia considerar imprescindível o auxílio do amigo na elaboração, desenvolvimento e redação dos projetos. No entanto, Rui Barbosa, susceptível, difícil, escrupuloso, punha constantemente o ministro em cuidados. No dia 6 de maio de 1882, Rodolfo, tentando apaziguar os ânimos, contornar um caso de melindre e demover Rui da ameaça de abandonar a Comissão de Instrução Pública, se viu obrigado a enviar, de seu gabinete ministerial, o seguinte bilhete ao amigo:

Não sei a que ato de exaustoração contra ti praticado te referes; nem na Câmara, nem alhures, vi nisso falar-se, nem mesmo remotamente a tal aludir-se. Compreendes que qualquer cousa nesse sentido não envolveria somente a ti, senão a mim também, já como amigo, já como ministro do império, o qual com a Comissão de Instrução Pública quase pode dizer-se forma uma mesma vontade. ${ }^{148}$

Rui ainda relutou, não queria transigir, mas Rodolfo, sabendo bem lidar com o amigo, conseguiu contornar a situação, mantê-lo na chefia da Comissão de Instrução Pública e acabou contando com a sua colaboração durante todo o tempo em que foi o ministro da Pasta do Império no gabinete presidido por Martinho Campos ${ }^{149}$.

As cartas e os bilhetes enviados a Rui durante este período são pródigos nas referências aos planos que acalentavam para a melhoria da instrução pública no Brasil. Jovens ativos e em pleno entusiasmo viviam elaborando pareceres, promovendo reuniões, visitando colégios, redigindo

\footnotetext{
${ }^{148}$ Correspondência de Rodolfo E. de Souza Dantas, vol. II, pp. 73,74.

${ }^{149}$ Deste gabinete fez parte, ocupando a Pasta da Guerra, o deputado Afonso Augusto de Moreira Pena, eleito em 1906, cinco anos após a morte de Rodolfo Dantas, presidente da república.
} 
relatórios, nos quais, às vezes, podiam ser surpreendidos em lances de pura impetuosidade, como este que se lê em um relatório apresentado na Assembléia Geral: "O estado não tem o direito de ser indiferente ao cultivo da inteligência popular"150.

A obstinação e o entusiasmo eram tantos que extrapolaram a Pasta do Império, contagiando o imperador e ele, então, desejou conhecer o projeto de instrução pública que ali estava sendo gestado. Assim que soube do fato, Rodolfo, esfuziante, escreve a Rui. "Logo que tiveres uma prova boa do parecer, manda-me, para que eu a envie ao imperador, que está doido por lerte" 151 .

Em que pese a boa vontade, o entusiasmo e os altos propósitos dos dois jovens parlamentares, estreantes no exercício do poder, bem pouco puderam realizar, dada a curta duração daquele gabinete (pouco mais que cinco meses).

De positivo mesmo o que fizeram foi deixar pronto e regulamentado, através do decreto $\mathrm{n}^{\circ}$ 8.602, de 23 de junho de 1882, 0 regimento especial que dispunha sobre provas e processos nos concursos para provimento de cargos de professores do Imperial Colégio Pedro II.

Poucos homens na história do Brasil tiveram na carreira política uma ascendência tão vertiginosa quanto Rodolfo Dantas: deputado aos vinte e quatro anos de idade e ministro aos vinte e oito.

Segundo filho do conselheiro Manuel Pinto de Souza Dantas, Rodolfo nasceu em Salvador em 1854 e morreu em Paris, em 1901, onde se achava para tratamento de saúde. De família abastada, bonito e inteligente, educou-se em meio a uma sociedade elegante e movimentada, mas que logo o cansou, da mesma forma como logo o cansou a vida pública, da qual se afastou discretamente, sem alarde ou ressentimentos.

Verdadeiro achado literário é o símile teatral empregado por Joaquim Nabuco para explicar este afastamento. A seu modo de ver, a atitude

\footnotetext{
${ }^{150}$ Maria de Lourdes Mariotto Haidar, O ensino secundário no império brasileiro, p. 33.

${ }^{151}$ Correspondência de Rodolfo E. de Souza Dantas, vol. II, p. 72.
} 
de Rodolfo Dantas não representava apenas a "repugnância passageira do ator por um papel que the distribuíssem, mas o seu tédio profundo pelo próprio teatro" ${ }^{\text {152. }}$. Quando após a proclamação da república voltou ao assunto, viu Nabuco neste cansaço de Rodolfo Dantas sinais de debilidade das próprias instituições monárquicas.

Há, porém, quem veja neste afastamento a influência de sua esposa, Alice São Clemente. A filha do conde de São Clemente, a bela herdeira de vastas extensões de terra jamais escondeu, nem disfarçou, a aversão sentida pelo ambiente político, que a seus olhos não passava de um desprezível jogo de interesses e ambições.

É mais uma hipótese que não decifra completamente este enigma que desperta tanto o interesse e a curiosidade de quem estuda a política institucional dos últimos anos da monarquia brasileira. Para aqueles que mais de perto o conheceram, Rodolfo Dantas era verdadeiramente uma promessa, com um futuro promissor na política pelo espírito de liderança, que era um dos principais atributos políticos de seu pai. Joaquim Nabuco, que com ele conviveu largamente, diz que Rodolfo combinava em si qualidades que "nenhum outro jovem político reuniu", pertencendo de forma isolada "a uma escola inteiramente diversa da de todos" ${ }^{\prime 153}$.

E Rodolfo Dantas, Rui Barbosa e, naturalmente, Joaquim Nabuco também eram todos leitores de Ramalho Ortigão.

\section{7 - O movimento abolicionista}

O ano de 1878, que marca o retorno do Partido Liberal ao poder, é igualmente marcante nas vidas de Joaquim Nabuco, Rui Barbosa e Rodolfo Dantas, três estreantes na Câmara dos Deputados, três novos habitantes do Rio de Janeiro, três promessas dos liberais. Fixando residência nesta cidade,

\footnotetext{
${ }^{152}$ Joaquim Nabuco, Escritos e discursos literários, p. 75.

${ }^{153}$ Ibidem, p. 74.
} 
após dois anos de ausência a serviço da diplomacia brasileira ${ }^{154}$, Joaquim Nabuco principia, ainda neste ano, a campanha que nobilitaria seu nome e haveria de marcar a sua vida: a campanha pela libertação dos escravos.

Talvez por inspiração do governo português que neste ano de 1878 havia declarado ilegal a escravidão em Portugal e suas colônias, inicia-se no Brasil um grande movimento em prol da extinção total do cativeiro no país. De tudo o que já havia sido feito pelos escravos, nada podia ser comparado ao movimento deflagrado neste ano por Jerônimo Sodré, na Câmara do Deputados. Um simples pronunciamento no recinto parlamentar, ouvido, entre outros, por Joaquim Nabuco, desencadeou uma intensa mobilização que praticamente alcançou todos os setores da sociedade e atingiu todas as camadas da população.

E é muito natural que o pronunciamento do deputado pela Bahia em prol da libertação dos escravos tenha suscetibilizado Joaquim Nabuco. Afinal, nada incomodava e constrangia mais os diplomatas brasileiros que serviam no exterior do que uma certa perplexidade condenatória, pairando no ar, sempre que se fazia menção ao regime escravocrata que ainda perdurava no Brasil. E mais que isso, a própria relação com pessoas de países mais bem resolvidos socialmente parecia alertar os diplomatas brasileiros para o absurdo da situação vivida pelos negros em seu país. Considere-se agora o caso particular de Joaquim Nabuco que chegava da Inglaterra, um país que, como nenhum outro, mais fundamente imprimiu em seu espírito o sentimento da liberdade, revelado, principalmente, na igualdade de direito que a todos assistia perante a justiça.

Apesar dos seus séculos de nobreza, das suas residências históricas, da sua riqueza e posição social, o marquês de Salisbury e o duque de Westminster estão certos de que diante do juiz são iguais ao mais humilde de sua criadagem. ${ }^{155}$

\footnotetext{
${ }^{154}$ Ele havia servido primeiramente nos Estados Unidos, morando no mesmo hotel de Saldanha da Gama e depois na Inglaterra, quando então freqüentou a residência do barão de Penedo, amigo que era, desde os tempos de academia, de seu filho Artur.

${ }^{155}$ Joaquim Nabuco, Minha formação, p. 119.
} 
E é muito natural que para espíritos impregnados de justiça e liberdade $\mathrm{o}$ pronunciamento de Jerônimo Sodré funcionasse como um verdadeiro rastilho de pólvora. Daí que a fase final do movimento abolicionista, aquele que vai de 1879 a 1888, começou mesmo na Câmara dos Deputados e não, como se chegou a pensar, na Gazeta de Notícias de Ferreira de Araújo. Nesse jornal, José de Patrocínio em sua seção "Semana Política", nada mais fazia do que apoiar Joaquim Nabuco e seus companheiros de parlamento, em uma atuação até bastante discreta se comparada com o papel posteriormente ocupado por ele dentro do movimento.

Nabuco, que no recinto fechado da Câmara seguidamente ocupava a tribuna em defesa dos escravos, ia pouco a pouco minando a resistência dos parlamentares mais intransigentes, representando desta maneira um papel político no movimento, enquanto José do Patrocínio, depois de passar da reflexão para a ação, atuava nos teatros, nas praças, nas ruas, propagando a idéia, popularizando o movimento, convocando, incitando para a luta, representando assim um papel de caráter mais revolucionário, que se desenvolvia em espaço aberto e em contato direto com o povo. Cada qual compunha um grupo, cujas atuações, embora em campos diferenciados, complementavam-se, refletiam-se e estimulavam-se mutuamente.

Até por volta de 1884 estiveram entregues à própria sorte, combatendo sozinhos, entrincheirados cada qual com seu grupo, arrostando com todo tipo de dificuldade, para só então conhecerem as duas primeiras grandes conquistas, com a adesão sucessiva dos dois partidos políticos do país. A partir daí o movimento se espalha, difunde-se, cresce e assume proporções inimagináveis seis anos antes.

Segundo Joaquim Nabuco, nesta fase o movimento reúne e conjuga os três principais segmentos representativos de toda a sociedade brasileira: a nobreza, a classe política e o povo. O primeiro deles é representado pelo espírito humanitário da princesa Isabel; o segundo conta com três representantes: o conselheiro Dantas, que colocou a serviço da causa abolicionista o Partido Liberal, Antônio Prado, que foi responsável pela retirada do veto de São Paulo à abolição, desestruturando a resistência paulista, e João Alfredo, presidente do gabinete conservador que abraçou a causa e teve a 
coragem de por em votação a lei em 13 de maio; o terceiro segmento é representado pelo espírito revolucionário, que ninguém encarnou com mais propriedade do que José do Patrocínio, uma espécie de oráculo do movimento, cuja atuação não ficou restrita às páginas dos jornais, ganhando as ruas da cidade com a organização de conferências públicas. Empenhando-se de corpo e alma na campanha, formou núcleos abolicionistas, colaborou para a fuga ou providenciou esconderijos para escravos fujões, entre outras ações de risco.

$$
\text { Ele é uma mistura de Spartaco e de Camille }
$$

Desmoulins... Os que lutavam somente contra a escravidão, eram como os liberais de 1789 , da raça dos cegos de boa vontade, senão voluntários, que as revoluções empregam para lhes abrirem a primeira brecha... Patrocínio é a própria revolução. ${ }^{156}$

Nascido em Campos dos Goitacazes, na província do Rio de Janeiro, a 8 de outubro de 1853, aos quinze anos de idade seguiu José do Patrocínio para a corte e, porque sonhava com a medicina, empregou-se como servente-aprendiz na farmácia da Santa Casa de Misericórdia. Não Ihe sendo possível realizar o grande sonho, contentou-se com um diploma da Escola de Farmácia, porém, não quis exercer a profissão, não quis ser boticário, preferindo antes a carreira das letras para a qual sentia um pendor maior como se a ela realmente estivesse predestinado.

É esta tendência para as letras que o leva em 1875, logo após a formatura, a fundar com Demerval da Fonseca, uma revista quinzenal, cujo nome, Os ferrões, traz automaticamente à lembrança o título dos folhetos que quatro anos antes passaram a ser editados em Portugal, por Eça de Queirós e Ramalho Ortigão. Talvez não seja tão difícil demonstrar que Os ferrões não passam hoje de um filho quase totalmente esquecido de As farpas. Que elas, na época, tiveram influência e muito contribuíram para formação do espírito crítico de toda uma geração de jovens dá testemunho o depoimento de Ricardo Jorge, referido no capítulo anterior. E se lá se tratava da influência sobre jovens portugueses, um testemunho de 1887 de Ramalho Ortigão - personificando As farpas - pode servir como referência para o caso dos jovens brasileiros. Ele se

\footnotetext{
${ }^{156}$ Ibidem, pp. 243, 244.
} 
encontra em uma carta enviada do Brasil ao genro Eduardo Burnay. Nela, ao falar da maneira "inexcedível de cordialidade e afeição" ${ }^{157}$ com que havia sido acolhido pela sociedade brasileira, revela o seguinte a respeito do tratamento a ele dispensado pelos cadetes da Academia Militar:

Os alunos militares da Escola do Exército, que é aqui uma espécie de Escola de Saint-Cyr, fizeram-me uma ovação inolvidável como a um velho general que volta vitorioso de uma campanha. Os rapazes têm para mim as frases mais comoventes. Fui eu - dizem - que fundei a confraternidade intelectual da nação brasileira e da nação portuguesa. Fui eu que, pelo uso de uma independência de pensamento de que não há outro exemplo na história das literaturas contemporâneas, emancipei o espírito crítico de uma raça. A nenhum outro escritor a mocidade deve tanto, porque fui eu o único que durante a minha vida lhe dei a ela unicamente, sem nenhuma outra preocupação de conveniência ou de interesse, o meu coração inteiro. Sobre este tema inúmeras variações sonoras e bem cantadas. $^{158}$

Pode até haver algum exagero por parte do remetente que talvez não contasse com a divulgação desta carta íntima em que, por vanglória e desvanecimento, apenas pretendia causar um pouco de impressão ao genro. Mas, de qualquer forma, serve para revelar o seu prestígio junto às camadas mais jovens da população - um público-leitor de caráter ainda em formação para as quais ele funcionava como um verdadeiro modelo a ser imitado.

Muito provavelmente, fazendo parte desta camada, devia-se encontrar José do Patrocínio que desde os velhos tempos de Os ferrões vinha aparando a pena e apurando o gosto pela sátira política, enquanto desenvolvia as qualidades de polemista que o fizeram famoso. Mestres nesses assuntos é o que nunca lhe faltou.

Dois anos após aquela experiência - praticamente uma pasquinada estudantil de dez números - José do Patrocínio ingressa na Gazeta

\footnotetext{
${ }^{157}$ Rodrigues Cavalheiro, A evolução espiritual de Ramalho, p. 447.

${ }^{158}$ Ibidem, p. 447.
} 
de Notícias, publicando em folhetins um romance, hoje pouco conhecido, intitulado Mota Coqueiro, ou A pena de morte ${ }^{159}$.

É ainda no jornal de Ferreira de Araújo que assina com o pseudônimo de Proudhomme a seção intitulada "Semana Política", uma série de folhetins em que, na mais completa liberdade, comentou os acontecimentos políticos do Segundo Império. Ameaças de crise, boatos de corrupção, sobe e desce de ministros são alguns dos assuntos abordados nesta seção. Sempre irônico, jocoso, jamais despreza a sátira para representar as alternâncias próprias do jogo do poder.

Certo dia julga a Suprema Razão do Estado ser urgente fazer qualquer lei; escreve laconicamente um bilhete a um dos homens públicos: - venha cá depressa para alugar o coupé, que nesta data vai ficar sem freguês, porque Fulano já não me agrada. Está pronto o novo ministério, ou mesmo a nova situação. O país no dia imediato sabe que está de cima o Beltrano que substituiu o Fulano, e nada mais. ${ }^{160}$

Não era bem assim que as coisas se passavam e nem tampouco o imperador era a "Suprema Razão do Estado", mas o que diz vale pela forma burlesca com que o sistema foi posto em caricatura. Na verdade, o que realmente acontecia era serem chamados ao paço homens aos quais o imperador, depositando total confiança, considerava capazes de levar avante as reformas exigidas pela sociedade civil, casos, por exemplo, de Saraiva e a lei eleitoral, Dantas e a questão do elemento servil. Mas, como estavam sujeitos ao jogo de perde e ganha próprio do sistema parlamentar, nem sempre eram bem sucedidos e acabavam sendo substituídos. E em outros casos eram apeados do poder, não por gosto pessoal do imperador, mas em conseqüência de um recurso denominado "moção de desconfiança", expediente usado pela Câmara dos Deputados que punha em jogo a estabilidade do gabinete.

Mas não deixa de ser uma boa caricatura o texto transcrito, pertencente a uma crônica publicada em 19 de janeiro de 1880. Ainda se

\footnotetext{
${ }^{159}$ Além desse, publicou em 1879 um livro que deve se achar entre os primeiros romances a tratar de um tema tão caro ao neorealismo brasileiro. Seu título desvela seu conteúdo: Os retirantes. José do Patrocínio escreveu esta obra ainda sob efeito das impressões deixadas pela grande seca que assolou o Ceará, cenário que conheceu em companhia de Francisco de Paula Nei.

${ }^{160}$ Gazeta de Notícias, 19 de janeiro de 1880.
} 
viviam os tempos do gabinete de João Lins Vieira Cansansão de Sinimbu, que na pena galhofeira de José do Patrocínio foi rebatizado, juntamente com o seu ministério, de "John Lins \& Companhia", algo assim como se tratasse de mais uma firma inglesa encarregada, como tantas outras existentes na época, de grande parte dos serviços públicos do Rio de Janeiro.

Exemplo típico seriam os serviços prestados à população pelas empresas de transportes, as companhias carris, que interligando, através de bondes o centro da cidade com seus arredores, agilizaram os deslocamentos, estreitaram o convívio e impulsionaram o comércio. Daí porque serem consideradas as principais responsáveis pelas mais significativas transformações na vida e nos costumes dos habitantes daquele Rio antigo.

Vendo naquele animado movimento de ir e vir uma real possibilidade de acréscimo na receita, a Câmara dos Deputados, acatando uma resolução proposta pelo gabinete, decretou, em fins de 1879, um imposto de 20 réis sobre cada passagem de bonde. Descontente e inconformada com a medida governamental, a população tomou as ruas e ocupou as praças em protestos que tumultuaram a cidade.

Considerando o imposto verdadeira humilhação, os jornais conservadores ateavam fogo ao fogo e punham as paixões populares a serviço da campanha contra os liberais. Demagogos interessados em desestabilizar o gabinete aproveitavam a oportunidade para acirrar ainda mais os ânimos do povo contra o governo.

Foi necessária a mobilização das tropas, o comércio cerrou as portas e por alguns dias a desordem reinou nas ruas do Rio de Janeiro, acarretando prejuízos. A ordem só foi restabelecida com a determinação governamental de submeter o pagamento do imposto ao livre arbítrio de cada um: pagasse quem quisesse.

Se esta medida, um tanto quanto burlesca e extravagante, serviu para acalmar o povo, não garantiu estabilidade ao governo que passou a viver na incerteza da corda bamba. Sempre muito atento e melhor informado, José do Patrocínio principia a crônica da "Semana Política", publicada em 19 de 
janeiro de 1880, a mesma daquela passagem acima transcrita, com uma frase que espelhava exatamente a situação do gabinete Sinimbu.: "Durante a semana finda falou-se, com grande insistência, em crise ministerial”161.

Era evidente que $\circ$ gabinete liberal de 5 de janeiro de 1878 atravessava um período de crise. No entanto, o cronista, dissimulando, procurava passar ao leitor a falsa idéia de ceticismo e indiferença em que mantinha o seu estado de espírito: "o folhetinista, porém, conservou-se calmo e impassível. Não acreditou, não acredita na possibilidade de uma crise"162.

E segue nessa linha, garantindo a estabilidade do gabinete ${ }^{163}$, mas levantando suspeitas sobre negócios públicos, assegurando a confiança do imperador, mas criticando o governo pelas medidas adotadas, notadamente o caso do imposto sobre as passagens. "Decretam impostos sem plano, no intuito de ir buscar o dinheiro aonde o há"164.

Sendo filho de uma quitandeira e tendo passado boa parte de sua infância em uma fazenda, natural seria a identificação de José do Patrocínio - o Zé do Pato, como era conhecido - com as camadas mais simples da população, a arraia-miúda como se diz, da qual se fez paladino e defensor.

Foi um dos responsáveis pela popularização da Gazeta de Notícias, cuja penetração nestas camadas - refletida em sua tiragem - a ele deve boa parte do sucesso. E muito contribuiu para isso a utilização do artifício retórico que consiste em procurar romper as barreiras existentes entre aquele que escreve e aquele que lê, ou seja, a utilização da informalidade como meio de aproximação com os leitores. Tenha-se como exemplo disso o primeiro parágrafo do folhetim publicado na segunda-feira, 21 de junho de 1880, cujo título, "Meu bom amigo Zé-povinho", por si só já representava um grande apelo popular.

Há muito tempo o folhetinista não tem a satisfação de cavaquear exclusivamente contigo; não tem a honra de sinetar a

\footnotetext{
${ }^{161}$ Ibidem.

162 Ibidem.

${ }^{163}$ Mal haviam passados dois meses desde a publicação da crônica e Sinimbu era substituído por Saraiva.

${ }^{164}$ Gazeta de Notícias, 19 de janeiro de 1880.
} 
solidariedade indissolúvel que nos liga, apertando nas suas mãos os calos com que o trabalho condecora as tuas. ${ }^{165}$

O aperto de mão, o cavaco, o bate-papo descontraído, a conversa ao pé do ouvido - tudo diplomaticamente chancelado pelo brasileiríssimo verbo "sinetar". Após este começo, cordial e afetuoso, que serve para aproximar o leitor, o cronista justifica seu distanciamento: foram as peregrinações pelas esferas superiores a culpada de tudo. Soubessem que estivera percorrendo repartições ordinariamente interditas àqueles que o trabalho árduo havia condecorado as mãos, altas esferas onde eram comuns as casacas, as reverências, as frases de efeito em linguagem formal, bem diferente dos prosaicos cavacos a que estavam afeitos; ambientes freqüentados habitualmente por homens bem postos, de mãos lisas, em sua grande maioria, oriundos de uma classe social muito distante daquela de seu "bom amigo Zépovinho". E o cronista humildemente se justificava.

Levou-o a tal peregrinação, porém, o sentimento religioso do amor por ti, o desejo insaciável de ser-te útil em alguma cousa. Quis ver se, afagando os poderosos, obtinha deles um olhar complacente para os teus direitos; se revelando-lhes os teus sentimentos, as tuas aspirações, as tuas virtudes e os teus defeitos, chamava-os ao governo da justiça e da retidão. ${ }^{166}$

Mas, é com tristeza e desolação que confessa ter perdido seu tempo. Nas regiões elevadas por onde andou, seu "bom amigo Zé-povinho" é uma entidade absolutamente sem qualquer valor real, servindo unicamente para o benefício e o interesse de ambiciosos. Infelizmente havia constatado que naquelas altas esferas ele não passava de "um enorme zero, cuja curva" se estendia do "Amazonas ao Prata e do Paraguai e Paraná ao Atlântico"167.

Quando este folhetim de José do Patrocínio foi publicado na "Semana Política" da Gazeta de Notícias, o gabinete de 28 de março de 1880, organizado pelo conselheiro Saraiva, já estava em pleno funcionamento. 0 assunto em pauta era o projeto da nova lei eleitoral que Sinimbu havia deixado

\footnotetext{
${ }^{165}$ Gazeta de Notícias, 21 de junho de 1880.

166 Ibidem.

167 Ibidem.
} 
em discussão no Senado e desde o dia da posse, há quase três meses, parecia mesmo que os jornais não tinham outro assunto, nem sabiam falar de outra coisa que não fossem eleições diretas, sufrágio universal, reforma eleitoral.

O conselheiro Saraiva havia organizado seu gabinete tendo em vista a incumbência de fazer passar naquela casa, a Câmara Alta como se dizia, aquele projeto, verdadeiro sonho que os liberais vinham acalentando desde o manifesto público de 1868.

E desde o dia em que se soube que era do gosto do imperador aquela reforma, não houve mais dúvidas e foi geral sua aceitação, restando apenas saber de que maneira deveriam ser conduzidos os trabalhos nas duas casas do Parlamento. Havia um grupo de deputados que considerava indispensável a convocação de uma constituinte. O Senado pretendia que a reforma fosse conduzida através de simples lei ordinária, sem a revisão da carta que assegurava aos senadores um mandato vitalício. Depois de alguns pronunciamentos e muita conversa, acabou prevalecendo a vontade do Senado e foi mesmo como simples lei ordinária que o projeto tramitou no Congresso ${ }^{168}$.

Durante todo o tempo em que ele esteve em tramitação, o folhetinista procurou manter sempre bem informados seus leitores; diligente e zeloso, alertava seu "bom amigo Zé-povinho" para o perigo de ficar alijado do processo eleitoral: "A imprensa e vários deputados têm demonstrado à luz da evidência que tu és excluído das urnas, que esbulham-te sorrateiramente do direito de voto ${ }^{169}$.

Eram as manobras políticas em curso que o cronista denunciava, as mesmas que acabaram instituindo, para eleições que pretendiam ser diretas, um programa censitário restrito que, excluindo sumariamente do processo os analfabetos, exigia dos demais comprovação de capacidade, ou pelo exercício de profissões rentáveis, ou pela posse de bens que assegurassem meios de vida.

\footnotetext{
${ }^{168}$ Vale a penar lembrar que foi a Lei Saraiva que garantiu ao eleitor brasileiro o voto direto nos candidatos. Antes, quem neles votavam eram os representantes dos eleitores - eleições em dois graus.

${ }^{169}$ Gazeta de Notícias, 21 de junho de 1880.
} 
O folhetinista então conclamava o povo a se bater por seu próprio direito, com passeatas, conferências, discussões, debates e outras medidas que pudessem atuar no ânimo dos legisladores. Que evitasse o silêncio, pois ele poderia representar uma autorização para que o governo realizasse a reforma unicamente de acordo com os interesses da classe dominante. $\mathrm{E}$ segue nesse diapasão até o ponto de se tornar bombástico e incendiário.

Ainda que nominalmente só, possuis o direito de atirar pelos ares câmaras como a atual, que está pronta a bater-se por todas as idéias contanto que se conserve a situação. ${ }^{170}$

Romântico exaltado, mais propenso ao sentimento que à razão, José do Patrocínio, neste texto particularmente, revela-se um temperamento oposto ao de Ramalho Ortigão, comedido, racional, sem grandes arroubos ou cometimentos que sugerissem o uso de meios violentos para a mudança das instituições. A bem da verdade nem mesmo mudanças pregava, senão apenas aprimoramentos, como deixa claro em uma carta publicada pela Gazeta de Notícias, logo após a proclamação da república em seu país. Rememorando os tempos agitados do início da década de 1870 em Portugal e falando em seu nome e em nome de Eça de Queirós - companheiros na aventura editorial de As farpas - questiona a ação revolucionária pela qual pudessem ser responsabilizados.

Como se fosse um ato de contrição tardio, confessa que jamais pretenderam mudar o regime político porque não eram estimulados pela revolta que julgavam baseada no apetite que cada um possuía de "cevar-se nas prebendas e nas sinecuras" de que pretendia enxotar os outros, além de que acreditavam "não ser por meio de revoluções, mas sim por meio de simples revulsivos, que se tratam as atonias sociais"171, isto é, remova-se o abscesso e tenha de volta a saúde. Bem diferente era a atitude do panfletário brasileiro, conclamando o povo a bater-se por seus direitos com todas as armas e por todos os meios possíveis. Como recurso persuasivo, relembra os feitos históricos, as lutas passadas e os sacrifícios dos mártires na conquista da

\footnotetext{
${ }^{170}$ Ibidem.

${ }^{171}$ Ramalho Ortigão, Últimas farpas, p. 127.
} 
cidadania, lembrando que os antepassados brasileiros "subiram ao trono da soberania nacional por uma escada de cadáveres"172.

E por aí vai, apelando reiteradamente para esta entidade abstrata denominada "Zé-povinho" (personificada por Rafael Bordalo Pinheiro em uma das páginas do Álbum das Glórias), sempre no intuito de prevenir ou alertar o povo para o que se tramava no parlamento. E para tanto recomenda cautela, precaução e muito cuidado com os interesses em jogo: "É dever do meu amigo Zé-povinho prestar seriamente atenção ao projeto, enquanto é tempo"173. E para maior efeito retórico, fecha a catilinária com um solene Caveat populus, que tomou emprestado ao latim, o idioma de Cícero.

A seção intitulada "Semana Política", assinada por José do Patrocínio com o pseudônimo de Proudhomme, começou na Gazeta de Notícias e terminou na Gazeta da Tarde, adquirida por ele e o sogro, após a morte de Ferreira de Menezes. E durante muito tempo funcionou, assim como uma espécie de muro de arrimo, para os deputados abolicionistas, que daí recebiam todo o apoio de que necessitavam para a divulgação de suas atividades dentro do parlamento. Joaquim Nabuco, que muito dela se beneficiou, sempre soube reconhecer a sua importância para o movimento.

A raça negra deu ao jornalismo brasileiro e à causa abolicionista três homens de valor inquestionável: Luís Gama, Ferreira de Menezes e José do Patrocínio. O primeiro deles, talvez por atuar na província de São Paulo, seja menos conhecido, porém não menos importante; já os outros dois, por atuarem no epicentro do movimento, a corte do Rio de Janeiro, são mais lembrados, notadamente este incansável propagandista do abolicionismo que foi José do Patrocínio.

É estupenda a soma de talento e a variedade de moldes que esse homem extraordinário consumiu nessa obra meritória. Não houve nota de paixão humana, desde as mais sublimes até as mais sombrias, que não passasse na sua pena, formando uma sinfonia assustadora, em que se erguiam as mais altas aspirações do espírito

\footnotetext{
${ }^{172}$ Gazeta de Notícias, 21 de junho de 1880.

${ }^{173}$ Ibidem.
} 
humano, gemiam as mais angustiosas lamentações da raça negra e reboavam as mais cruéis imprecações do cativeiro. A liberdade, o trabalho, a dignidade humana, a resignação, a piedade, o perdão, a caridade, a submissão, a lisonja, a mentira, a calúnia, a confissão de culpa, o arrependimento, o cansaço, a dor, a revolta, o crime - tudo passava de roldão, ferindo todas as gamas, levando a cada ouvido a impressão que o devia abalar. ${ }^{174}$

Foi companheiro inseparável de José do Patrocínio nesta cruzada abolicionista Francisco de Paula Nei, repórter da Gazeta de Notícias que viria a se tornar um dos mais afamados boêmios da época. Haviam ingressado quase ao mesmo tempo no diário de Ferreira de Araújo e se tornaram grandes amigos.

Paula Nei era natural de Fortaleza, Ceará, onde nasceu em 1858, sendo cinco anos mais moço que José do Patrocínio. Por lá permaneceu até a fase dos estudos preparatórios, tendo convivido com Araripe Júnior, Clóvis Bevilacqua e Capistrano de Abreu. Seguiu depois para o Rio de Janeiro com um vago sonho, muito mais dos pais que propriamente seu: um filho formado em medicina.

Corria o ano de 1877 e como a mesada enviada pelo pai, alfaiate, se revelou minguada para a vida na corte, resolveu procurar emprego e complementar o orçamento. Após alguma indecisão, optou pelo jornalismo, profissão romântica da qual trazia pequena experiência ainda dos tempos da província. Lá, ao lado de Pedro de Queirós e Clóvis Bevilacqua, havia redigido o galileano jornalzinho - E Pur, Si Muove.

Jovem e audacioso, arriscou e foi, sozinho, sem mesmo contar com uma simples carta de apresentação, subir a escada do prédio número 70 da Rua do Ouvidor e apresentar-se a Ferreira de Araújo, diretor de redação da Gazeta de Notícias, que logo foi conquistado pela simpatia daquele rapaz.

\footnotetext{
${ }^{174}$ Tobias Monteiro, Pesquisas e depoimentos para a História, pp. 59, 60.
} 
O grande jornalista descobriu nele, pela sua conversa, pelo seu jeito, que o moço prometia. Escutou-o, declamando uns versos da sua lavra. Não teve dúvidas. Colocou-o. Ia ser repórter. ${ }^{175}$

E foi assim que ele ingressou na Gazeta de Notícias e conheceu José do Patrocínio, a quem se ligou pelo resto da vida.

Celebrizado em obras de Coelho Neto, Paula Nei foi personalidade destacada de uma boêmia carioca que no último quartel do século XIX gravitou ao redor da Rua do Ouvidor. Espírito satírico, famoso pelo anedotário, achava-se constantemente pronto e à vontade para pôr a sensibilidade e a inteligência a serviço do riso, sendo sempre a alegria dos ambientes que freqüentava pelos chistes, rasgos e tiradas que costumeiramente intercalava na conversação diária. Poeta de escassa produção, toda ela espalhada pelos jornais e revistas por onde passou, formava, junto com José do Patrocínio, Aluísio Azevedo, Coelho Neto, Guimarães Passos, Olavo Bilac, Pardal Mallet, um grupo de boêmios, uma roda literária que marcou época. Quem retratou esta boêmia, esta mocidade alegre, freqüentadora de cafés e redações de jornais - verdadeiros cenáculos e ponto de encontro da intelectualidade - foi Coelho Neto em duas obras com nítidos traços autobiográficos: A conquista, de 1889 e Fogo-fátuo, lançada vinte anos depois.

O centro aglutinador de toda essa esfuziante juventude era a Rua do Ouvidor, seguramente o mais famoso endereço do Rio de Janeiro nos tempos em que por aí principiaram a chegar as cartas de Ramalho Ortigão. Ela que fora a rua do padre Homem da Costa até 1780, quando nela passou a morar Francisco Berquó da Silveira, ouvidor da comarca, representava uma verdadeira artéria a alimentar o coração da cidade. Por ela desfilavam as personalidades mais notáveis da época e tudo nela se concentrava: confeitarias, cafés, restaurantes e, principalmente, lojas, como a Notre Dame de Paris, uma espécie de representante carioca da moda parisiense, freqüentada pelos elegantes endinheirados da corte ou da província em visita ao Rio de Janeiro. Dividida em dois pavimentos, no térreo estava instalada a

\footnotetext{
${ }^{175}$ Raimundo de Menezes, A vida boêmia de Paula Nei, p. 45, 46.
} 
loja propriamente dita, com mercadorias e caixeiros encarregados do atendimento, enquanto no andar superior se achavam as máquinas de costuras para reparos, ajustes ou confecções, uma oficina que em 1885, diz a Gazeta de Notícias, contava com mais de quarenta operárias.

Quase todos os jornais importantes da época estavam estabelecidos na Rua do Ouvidor, onde funcionavam redações e oficinas. Eram os casos do Jornal do Comércio, de O País, do Diário de Notícias e da Gazeta de Notícias, embora, neste último, somente a redação, já que a oficina se encontrava na Rua Sete de Setembro. Todos diários, aos quais se juntava a Semana, um conceituado hebdomadário que circulava aos sábados.

De raríssimos edifícios públicos, a Rua do Ouvidor, embora tomada pelo comércio, não deixava de ser um ambiente de sociedade, um local de encontro casual ou combinado de pessoas graves ou frívolas, que tanto podiam tecer comentários a respeito do câmbio, da cotação do café, da queda de um ministério como da estréia de uma nova comédia no teatro Cassino. Era ali também o local predileto para a formação de "igrejas" e rodinhas de boêmios.

Em cada café, ou confeitaria, pontificava uma escola literária: os naturalistas, no Cailteau; os românticos na Castelóes; no Deroche, já em decadência, os simbolistas; e, finalmente, os parnasianos, que era o grupo de Nei, na Pascoal... ${ }^{176}$

Era, este último, aquele mesmo grupo, há pouco citado, do qual faziam parte Guimarães Passos, Olavo Bilac, Coelho Neto e, naturalmente, Paula Nei, que, depois de uma curtíssima temporada em Salvador, jamais abandonou a cidade do Rio de Janeiro. Tendo principiado na Gazeta de Notícias a carreira de repórter, passou depois para a Gazeta da Tarde, seguindo, como fiel escudeiro, a José do Patrocínio. Mas fez reportagens também para o Diário de Notícias e para a Cidade do Rio e, ao lado, de Pardal Mallet e Coelho Neto lançou no ano da proclamação da república o periódico $O$ Meio, de vida curta, fechado que foi pela polícia após o $13^{\text {o }}$ número. Dirigiu ainda, entre 1893-1894 a revista O Álbum.

\footnotetext{
${ }^{176}$ Ibidem, p. 68.
} 
Nas rodas de boa prosa da época, nas mesas dos cafés e confeitarias onde também pontificavam Artur Azevedo, Carlos de Laet e Ferreira de Araújo, sempre foi recebida com prazer, entusiasmo e alegria a figura descontraída e simpática de Francisco de Paula Nei, o poeta bissexto que infelizmente faleceu muito novo, aos trinta e nove anos de idade.

Ele era, sem favor, o encanto de todas as rodas, pois sabia, de verdade, animar uma conversa, coisa de que não eram muitos homens capazes. Não ficava, ao modo de peru em círculo de giz, preso a qualquer assunto. Esvoaçava sobre todos, marcando-os sempre com uma frase de espírito. E não deixava que a palestra morresse num angustioso silêncio, quando o motivo já se mostrava esgotado. Saltava para outras searas em busca de nova colheita. E era, assim, um convite a todas as opiniões e a todos os temperamentos. Sua presença, por isso, era sempre bem recebida. ${ }^{177}$

Ainda sobre este tema da conversação ou boa prosa, seja aqui lembrada a figura de Teixeira de Vasconcelos, escritor de quem Ramalho Ortigão dizia preferir a palestra íntima e descontraída à falta de sinceridade de seus livros e, também, Eça de Queirós, sempre reverenciado por aqueles que de perto o conheceram pela singularidade de sua conversação.

A 19 de agosto de 1900, três dias após a morte do romancista, Olavo Bilac publicou uma crônica na Gazeta de Notícias, um belo e sentido necrológio no qual, entre outras coisas, relembra o inverno parisiense em que teve oportunidade de freqüentar a casa do escritor, sempre atraído por sua boa e cativante prosa. Lembra Bilac que nos encontros, reuniões e rodinhas de amigos, Eça de Queirós, naturalmente se tornava o foco das atenções porque "era um conversador inimitável, porque gostava de conversar, porque se deixava levar pelo uso das próprias idéias"178.

Já Ramalho Ortigão, em outra oportunidade, nesta mesma Gazeta de Notícias, dizia - por conseqüência talvez de um encarecido e irrefreável francesismo - que Paris era "a única cidade do mundo em que

\footnotetext{
${ }^{177}$ Ciro Vieira da Cunha, No tempo de Paula Nei, p. 154.

${ }^{178}$ Gazeta de Notícias, 19 de agosto de 1900.
} 
verdadeiramente" 179 se podia conversar. Supondo-se que assim fosse e que certo ele estivesse, seria então o caso para se dizer: - É porque lá morava Eça de Queirós.

\section{8 - Joaquim Nabuco em Lisboa}

No dia 22 de fevereiro de 1881, a Gazeta de Notícias publicou uma carta de Ramalho Ortigão alusiva à passagem de Joaquim Nabuco por Lisboa, primeira etapa de uma longa campanha européia por ele envidada, durante o recesso da Câmara, em prol dos escravos brasileiros.

De acordo com o correspondente, a recepção e as atenções a ele dispensadas não poderiam ter sido melhores, sendo uma boa prova disso 0 que havia ocorrido na Câmara dos Deputados, no dia em que lá compareceu acompanhado do adido da embaixada brasileira em Lisboa, Araújo Beltrão, resolvidos que estavam a assistir aos debates. Mal haviam tomado assento na tribuna diplomática, quando se aproximou o deputado Antônio Cândido liderando uma comitiva encarregada de convidar Joaquim Nabuco a se servir de uma cadeira a ele destinada no próprio recinto da assembléia. Veja só, era como se o deputado brasileiro tivesse comparecido àquela sessão parlamentar, não para simplesmente assistir aos debates políticos, mas, sim, para ativamente participar deles.

Que maior honraria poderia ser prestada a um parlamentar estrangeiro do que isto: ser por todos os participantes de uma assembléia considerado um de seus pares?

O jornal Correspondência de Portugal, porém, viu naquele procedimento da Câmara uma quebra do regimento que, além de ofensiva às praxes, poderia abrir um precedente perigoso: o de obrigar-se a admitir no recinto da assembléia todo parlamentar estrangeiro que porventura viesse honrar o parlamento português com sua presença na tribuna diplomática.

\footnotetext{
${ }^{179}$ Ramalho Ortigão, Notas de viagens, p. 20.
} 
Ramalho Ortigão, no entanto, rebate as considerações do jornal português argumentando que a honraria não era propriamente prestada ao deputado, mas ao abolicionista portador de uma idéia generosa, ao filantropo que sonhava com a redenção de uma raça, ao representante humanitário de dois milhões de almas.

E foi realmente nesta qualidade que Joaquim Nabuco, aproveitando as férias parlamentares, havia empreendido aquela viagem à Europa. Era sua intenção conversar com abolicionistas famosos, como Victor Scholcher, venerando libertador das colônias francesas, bem como estabelecer contatos com organizações anti-escravistas, caso da Sociedade Abolicionista Espanhola, que lhe ofereceu um banquete e o aclamou membro da associação e da Anti-Slavery Society, que Ihe prestou uma sentida e honrosa homenagem.

Baseando-se no ponto de vista de que o propósito da viagem de Nabuco era advogar e defender a causa dos escravos brasileiros, Ramalho elaborou uma argumentação - contundente em sua simplicidade - para refutar o perigo do precedente aberto: se a Câmara homenageou o representante do abolicionismo brasileiro e se o Brasil era o único país do mundo ocidental a manter a instituição do cativeiro, uma vez libertos seus escravos jamais ela receberia a visita de outro abolicionista. No fundo, Ramalho pretendia que a homenagem fosse uma manifestação de liberalismo ${ }^{180}$ do parlamento português, um decisivo apoio à causa da liberdade ali pessoalmente representada pelo abolicionista brasileiro.

Não foi um indivíduo mais ou menos ilustre que a Câmara dos Deputados cumprimentou, recebendo no seu grêmio o senhor Joaquim Nabuco; foi a emancipação de dois milhões de negros que ela saudou na promessa que o chefe do partido abolicionista personificava. $^{181}$

A rigor, o conteúdo desta carta de Ramalho Ortigão, publicada pela Gazeta de Notícias no espaço do folhetim, não se achava restrito, tão somente, ao campo semântico das boas-vindas, da felicitação pela chegada de

\footnotetext{
${ }^{180}$ Liberalismo que também esteve representado pelo requerimento levado à mesa, solicitando, em consideração a Joaquim Nabuco, a abolição dos castigos físicos ainda existentes no exército português.

${ }^{181}$ Gazeta de Notícias, 22 de fevereiro de 1881.
} 
alguém. Admitia outras leituras, comportando especialmente uma, na qual, orientada pelo viés do liberalismo, ela poderia ser lida como uma pequena dissertação a respeito da servidão humana, que, embora apresente várias modalidades, aqui se achava consignada na exploração do homem pelo homem.

Quanto ao formato este texto seguia um modelo muito ao gosto do escritor e que poderia ser esquematizado pela fórmula a-b-a: primeiro uma introdução ao tema, seguida de uma variação sobre ele, finalizando pela sua retomada.

Das três partes, a primeira trata especificamente da visita feita por Joaquim Nabuco: o anúncio de sua chegada a Lisboa, os comentários dos jornais, a alusão ao livro Camões e os Lusíadas, a recepção na Câmara dos Deputados, além de algumas considerações a respeito de aspectos pessoais do homem que se havia empenhado em uma tão nobre, quanto desgastante campanha - o abolicionismo.

Ser o portador de uma idéia humanitária e generosa é uma bela cousa, mas possuir uma fisionomia em que se espelha a limpidez de uma convicção é predicado essencial para fazer circular uma idéia representada por um indivíduo. ${ }^{182}$

Já a segunda expõe e desenvolve, doutrinariamente, o tema da condição servil, que a escravidão moderna havia atualizado, e que no caso estava representada pela submissão que o sistema colonial português, mediante o uso da força, impunha aos negros africanos.

Quando esta carta foi escrita ainda não fazia três anos que Portugal havia abolido a escravidão em suas colônias e uma série de preconceitos formava a base de um ideário comum. Escravocratas portugueses, que tiveram suas economias seriamente abaladas pelo decreto do governo, justificavam o uso da força argumentando que os negros representavam uma raça inferior, cujo feitio moral, defeituoso, a tornava incompatível com a civilização e o progresso, sendo assim praticamente 
impossível o trabalho de moralização por outros meios. E com raciocínios semelhantes procuravam também justificar outros procedimentos adotados na colonização da África.

Ramalho tinha consciência das dificuldades enfrentadas pelo governo português para organizar o trabalho livre em seus domínios do ultramar, após o decreto de abolição, principalmente pela dificuldade de enquadrar os negros, agora livres, ao novo modelo a ser implantado, reconhecendo, no entanto, que o principal culpado era o próprio branco que no processo de dominação, quando não aniquilou, corrompeu a raça negra nas "fontes da moral coletiva, no sentimento da família e no sentimento da pátria"183.

Mas não era o aspecto econômico inerente à escravidão que Ramalho pretendia discutir e, sim, o aspecto humano que envolvia a questão. Para tanto adota um novo referencial, um outro ponto de vista, e a partir daí questiona o que seria a atitude do branco diante de uma situação semelhante àquela por ele imposta à raça negra.

Tão somente o que suspeito - sem com isto envolver alusões pessoais a ninguém - é que o branco, depois de tratado como o preto durante o decurso de um certo número de gerações, não seria talvez nem mais digno, nem mais inteligente, nem mais espirituoso, nem mais moralizado, nem mais progressivo, nem menos preto do que é hoje o outro. ${ }^{184}$

Pondo a nu a questão do elemento servil ele deixa evidente que existiam outros prismas de observação: para muito além daquele que era comum aos espoliadores, havia também o ponto de vista dos espoliados.

Ao retomar o tema da visita de Joaquim Nabuco, Ramalho Ortigão, lembrando o fato ocorrido no parlamento português, aproveita para responder ao periódico Correspondência de Portugal, o jornal conservador que havia considerado a atitude do deputado Antônio Cândido, além de leviana, ofensiva às normas da casa, por não se achar nas praxes:

\footnotetext{
${ }^{183}$ Ibidem.

${ }^{184}$ Ibidem.
} 
"Não está nas praxes?! Que diabo! Reformem-se as praxes" ${ }^{185}$, é o que ele sugere ao conservador periódico.

Mas não foi somente pelas páginas da Gazeta de Notícias que ele respondeu àquele intransigente órgão de imprensa. O mesmo aconteceu no opúsculo de As farpas publicado em janeiro de 1881. O texto que não tem as mesmas dimensões, nem o mesmo desenvolvimento da carta enviada ao diário brasileiro, é, todavia, muito mais contundente na contestação, quase toda ela trabalhada à base de zombarias e deboches. E não é para se considerar tão estranho que assim fosse, pois que, tenha-se em vista, eram matérias destinadas a público e a publicações diferentes, e, como dentre elas uma era editada em país estrangeiro, um tratamento mais irreverente, como o publicado em As farpas, poderia passar por difamação ou calúnia.

Serve muito bem para dar uma idéia da irreverência deste texto a maneira como foi tratada uma questão levantada pelo senhor Felipe de Carvalho, redator da Correspondência de Portugal. Assustado, perguntava ele como, após o precedente aberto com a visita de Joaquim Nabuco, deveria proceder a Câmara dos Deputados ao receber outros homens ilustres que fossem portadores de ideais tão nobres como os daquele visitante. Sarcasticamente, o autor de As farpas responde-lhe que a Câmara deveria proceder com eles da mesma maneira como procedeu com Nabuco: "recebeos na sala e oferece-lhes um fauteuil"186. Acrescentando a seguir:

Quando os fauteuils faltarem para dar assento aos homens que prestam no mundo para alguma coisa, irão para a galeria os deputados que lá estão em baixo e que não prestam para nada. Para o que eles lá fazem, pela maior parte, até no telhado poderão exercer! ${ }^{187}$

Na carta enviada à Gazeta de Notícias não há nada que se assemelhe a esta maneira sarcástica com que foram tratados os parlamentares portugueses. O que nela houve de mais contundente e radical foi aquele pedido de reforma das praxes parlamentares.

\footnotetext{
185 Ibidem.

${ }^{186}$ Ramalho Ortigão, Farpas esquecidas, vol. I, p. 54.

${ }^{187}$ Ibidem, p. 54.
} 
Mas não foi só na condição de político que Joaquim Nabuco recebeu homenagens em sua passagem por Lisboa. O escritor foi igualmente homenageado, e como convinha a esta condição em recinto muito mais alegre e bem mais descontraído. No hotel Central, foi-lhe oferecido um banquete pelo caricaturista Rafael Bordalo Pinheiro. Entre outros, estiveram presentes a esta homenagem Eduardo Coelho, diretor-proprietário do Diário de Notícias, Júlio César Machado e Ramalho Ortigão, representando os escritores portugueses, além de vários jornalistas. Com este jantar festivo, o artista da caricatura pretendia homenagear o Brasil na pessoa de Joaquim Nabuco.

Depois de uma longa permanência de mais de quatro anos no Rio de Janeiro, onde colaborou em jornais humorísticos como $O$ Mosquito e $O$ Bezouro, Rafael Bordalo Pinheiro havia retornado a Portugal para fundar, ao lado de Guilherme de Azevedo ${ }^{188}$, um semanário humorístico, ilustrado, cujo título, O António Maria, era uma homenagem ao homem forte da política portuguesa na época: António Maria de Fontes Pereira de Melo. Quando da visita de Joaquim Nabuco, quem redigia os textos que acompanhavam as ilustrações de Bordalo Pinheiro era Ramalho Ortigão, uma vez que desde setembro de 1880 Guilherme de Azevedo se achava em Paris, contratado que fora pela Gazeta de Notícias para ser o seu correspondente nesta cidade. Portanto foi na condição de eventual substituto que Ramalho aceitou o convite dos colegas para entrar na publicação. A princípio, quis recusar, lembrando nomes de jornalistas mais afinados com a linha editorial da publicação. Sendo em vão toda tentativa de recusa, dada a insistência dos fundadores que ameaçavam até encerrar a publicação, acabou aceitando a incumbência com a condição de restituí-la no mesmo dia em que o titular retornasse a Lisboa.

Acontece, porém, que Guilherme de Azevedo jamais retornou. Faleceu em Paris no dia 8 de abril de 1882, sendo sepultado no cemitério de Saint-Ouen, para onde foi levado por quatro amigos, entre eles, Ferreira de Araújo, proprietário da Gazeta de Notícias e Rafael Bordalo Pinheiro que teve o cuidado de tirar-Ihe a máscara em gesso.

\footnotetext{
${ }^{188}$ Guilherme de Azevedo (1839-1882), poeta e jornalista português, autor de A alma nova, livro de versos de inspiração social, filiado ao Realismo. Trabalhou em vários jornais de Lisboa e foi correspondente da Gazeta de Notícias em Paris de 1880 a 1882.
} 
Neste mesmo dia, Ramalho Ortigão enviou uma carta à Gazeta de Notícias comunicando a seus leitores o desaparecimento do correspondente responsável pelas seções "Correio de França" e "Cartas de Paris", que semanalmente ilustravam as páginas do diário brasileiro: "Um telegrama comunica a um jornal desta manhã, que morreu Guilherme de Azevedo"189.

Nesta carta publicada pelo diário brasileiro a 14 de maio de $1882^{190}$, um domingo de outono, Ramalho enaltece as qualidades de Guilherme de Azevedo como folhetinista e, principalmente, como o melhor colaborador que Bordalo Pinheiro poderia ter encontrado. $O$ poeta e 0 desenhista eram dois temperamentos boêmios em perfeita harmonia, almas gêmeas, alegres e risonhas, fundindo-se em criações homogêneas e compactas.

Muitas das páginas em que Guilherme de Azevedo e Bordalo trabalharam de colaboração na Lanterna Mágica, no Álbum das Glórias e no António Maria, ficarão como modelos do gênero, como obras-primas de uma arte dupla, a que podemos chamar a ópera cômica do desenho. ${ }^{191}$

Após a morte e a certeza de que Guilherme de Azevedo não mais retomaria seu lugar em $O$ António Maria, Ramalho, que contava ocupá-lo apenas interinamente, deixou a publicação, pondo fim a um período de quase ano e meio de colaboração literária naquela folha ${ }^{192}$. Portanto, é na dupla condição de correspondente em Portugal da Gazeta de Notícias e redator de $O$ António Maria que Ramalho Ortigão comparece àquele jantar do hotel Central o festivo banquete oferecido a Joaquim Nabuco por Rafael Bordalo Pinheiro.

E se este brindava o escritor no recinto de um hotel, Antônio Cãndido homenageava no parlamento o deputado, com sua imagem de liberal

\footnotetext{
${ }^{189}$ Gazeta de Notícias, 14 de maio de 1882.

${ }^{190}$ Uma semana depois publicou em O António Maria novo texto alusivo à morte de Guilherme de Azevedo, matéria recolhida integralmente no volume III de As farpas e, com a supressão dos dois primeiros parágrafos, no volume II de Figuras e questões literárias. É para lamentar o fato de se haver recolhido um mesmo texto em duas obras distintas de Ramalho Ortigão, enquanto permanece inédita em livro a carta publicada pela Gazeta de Notícias, que nada fica a dever ao texto de O António Maria.

${ }^{191}$ Gazeta de Notícias, 14 de maio de 1882.

${ }^{192}$ Uma parte desta produção foi incorporada em As farpas, editadas por David Corazzi, e a outra compõe os dois volumes de Farpas esquecidas, uma publicação da Livraria Clássica Editora.
} 
progressista iluminada por uma aura romântica. E foi esta aura e esta imagem de libertador que Ihe abriram os caminhos da Europa, a começar pela península Ibérica. Mais que tudo, aquela viagem era tida e havida por todos como verdadeira representação de um périplo em defesa do direito e da liberdade. E o tema e seu nome intimamente se associavam e desde o Brasil se irmanavam pela defesa de negros e também de coolies (imigrantes chineses), como ocorreu quando se ventilou a possibilidade de o país lançar mão, à semelhança de Cuba, deste tipo de mão de obra.

Ao se discutir o assunto na Câmara dos Deputados, prontamente Joaquim Nabuco denunciou os interesses escusos que se achavam por trás daquela aparentemente simples política imigratória. Na verdade, aquilo não passava de uma nova e mal disfarçada forma de exploração do homem pelo homem, de um novo tipo de servidão que as plantations de Cuba, onde chineses submetidos a contratos desumanos e fraudulentos, claramente vantajosos aos fazendeiros, punham às claras.

Maior advogado que Joaquim Nabuco dos interesses destes trabalhadores foi sem dúvida alguma Eça de Queirós. Mais de uma vez, durante o tempo em que serviu no consulado de Havana, denunciou a situação destes colonos chineses embarcados no porto de Macau, sob a responsabilidade do governo português.

Perante a lei cubana, eles se dividiam em duas categorias: os aportados na ilha até o ano de 1861 e os que lá chegaram após esta data, sendo que todos se viam obrigados a assinar um contrato de prestação de serviço de oito anos, findos os quais, os que chegaram antes de 1861, seriam considerados livres e com direito à requisição da cédula de estrangeiros no consulado de Portugal e os demais teriam o prazo exíguo de dois meses para deixar a ilha ou firmar novo contrato.

O que em realidade Eça de Queirós denuncia e combate é o mecanismo burocrático montado em Havana à revelia do governo de Madri e sob o comando dos fazendeiros; um kafkaniano emaranhado legislativo a interpor tamanhas dificuldades aos coolies - tanto para regularizarem a permanência quanto para deixarem a ilha - que se viam, no mais das vezes, 
obrigados a se engajar novamente nas plantations, submetendo-se a mais oito anos de um regime de trabalho que muito pouco se diferenciava da própria escravidão. Uma associação comercial montada na ilha cuidava de toda a transação, desde o embarque até a chegada nas fazendas, passando inclusive pelos cartórios de registro. E era função do cônsul de Portugal dirigir e fiscalizar esse negócio.

Por uma disposição fiscal da lei consular, esse comércio era altamente lucrativo para o cônsul. Aconteceu porém que o cônsul foi Eça de Queirós, que começou uma campanha oficial contra o comércio dos chins, que foi, finalmente, abolido. ${ }^{193}$

Joaquim Nabuco achava-se inteiramente a par da condição desumana a que estavam sujeitos os chineses de Macau, tanto em Cuba como no Peru, e é bem provável que houvesse tomado conhecimento, através de amigos comuns, do trabalho realizado por Eça de Queirós. Sabe-se que houve grande interação e até mesmo alguma convivência entre escritores portugueses e brasileiros da época, sendo elas quase sempre mediadas pela diplomacia e pela imprensa dos dois países. Convergências e divergências de pontos de vista era natural que houvesse, mas jamais serviram de bandeira para arrefecer o zelo e o respeito existente entre eles. Que sirvam de exemplos os casos de Eça de Queirós e Machado de Assis e, também, os de Jaime Batalha Reis e Joaquim Nabuco que depois de se conheceram nos Estados Unidos por volta de 1876, mantiveram em Londres uma estreita convivência, a despeito de toda divergência intelectual que pudesse existir entre eles. "Não me parece que jamais concordássemos sobre quaisquer idéias importantes, em Sociologia ou Arte"194, confessou um dia Jaime Batalha Reis.

Assim mesmo, quando em 1904 ele empreendeu o inconcluso projeto que visava $O$ descobrimento do Brasil intelectual pelos portugueses do

\footnotetext{
${ }^{193}$ Citado por Hermano Neves, "Eça de Queirós, homem de coração”, no In memorian, p. 18.

${ }^{194}$ Elza Miné, "Perfis de Nabuco em textos inéditos de Jaime Batalha Reis e Manuel de Oliveira Lima", in Leituras, p. 226.
} 
século $X X{ }^{195}$ o primeiro intelectual brasileiro de que pretendia se ocupar, chegando até a esboçar um estudo, seria justamente Joaquim Nabuco.

A imprensa e a diplomacia não só proporcionaram interação e conhecimento, como também serviram de intercâmbio cultural entre os dois países. Boa parte do que produziram jornalistas e escritores portugueses foi publicada na imprensa brasileira, cuja penetração em Portugal, ao que se sabe, era praticamente inexistente. Mas se perdia em quantidade de leitores, ganhava em qualidade, pois, ao menos, era lida pelos escritores que nela colaboravam, como dá testemunho uma carta de Eça de Queirós, enviada a Ramalho Ortigão. Vivendo em Bristol, ele rogava ao amigo que lhe escrevesse, pois desejava tomar conhecimento dele por ele mesmo e não através das páginas da Gazeta de Notícias: "Estranha maneira de receber notícias dum camarada..."196, queixava-se.

Esta carta é de 1881, tempos em que Eça também colaborava na Gazeta de Notícias. Alguns anos antes, porém, quando só Ramalho colaborava e ele ainda vivia em Newcastle, havia enviado uma outra comentando um convite feito ao amigo por aquele jornal. Segundo se depreende das palavras de Eça, tratava-se de uma "viagem organizada de recreio", de roteiro préestabelecido, cujas despesas seriam pagas pela Gazeta em troca das impressões deixadas no viajante, ou seja, Ramalho viajava, escrevia, o jornal pagava e imprimia.

A Eça, no entanto, não agradava este plano antecipado, com indicações metódicas dos lugares, paradas programadas, tempos cronometrados, afobação constante e limitadas possibilidades de um registro satisfatório das impressões causadas, mesmo porque o atordoante corre-corre, mais encobrindo que revelando, fazia daquilo tudo um "medíocre sistema de ver o mundo"197. Não, definitivamente, não poderia lhe satisfazer.

O que certamente ele aplaudiria com toda satisfação seria uma viagem de itinerário inteiramente programado e ao gosto dele, Ramalho.

\footnotetext{
195 Jaime batalha Reis, O descobrimento do Brasil intelectual pelos portugueses do século XX, organização, prefácio e notas de Elza Miné.

${ }^{196}$ Eça de Queirós, Cartas, p. 68.

${ }^{197}$ Ibidem, p. 54.
} 
Caberia à Gazeta de Notícias liberalmente promover os meios necessários para realizá-la, ao que ele, por sua vez, tudo devolveria em forma de belas e elucidativas notas de viagem que o jornal, também liberalmente, publicaria. Aí, sim, teria a aprovação plena dos leitores, a sua chancela e a garantia de que:

Não é só para você uma esplêndida aventura pessoal mas é para nós um livro único! Você será um Corot solto através do Orbe! Você tem o dom extraordinário de surpreender a realidade exterior no seu tom flagrante - e nenhum escritor europeu ou americano nos poderá dar uma tão maravilhosa descrição do que se vê em "Do Havre até ao Havre dando a volta por Ceilão". Você deveria começar pelo Brasil e contar-no-lo à Taine: que livro! ${ }^{198}$

Algum tempo depois destes sonhos fantasiosos do autor de $O$ mandarim, Ramalho verdadeiramente empreendeu uma viagem ao Brasil, mas ficou devendo o tão sonhado livro - à maneira de Taine - sobre o país. E é este, por sinal, o tema do próximo capítulo.

${ }^{198}$ Ibidem, p. 54. 


\section{3 - A viagem de Ramalho Ortigão ao Brasil}

Se os destinos políticos do Brasil passavam para as mãos dos liberais algum tempo depois de Ramalho Ortigão iniciar sua longa trajetória de correspondente em Lisboa da Gazeta de Notícias ${ }^{199}$, voltavam, depois de muito sobe e desce de ministérios, às mãos dos conservadores quando ele esteve no país, nos fins do ano de 1887.

Desde 20 de agosto de 1885, o Brasil era comandado pelo barão de Cotegipe, incumbido que fora pelo imperador de formar aquele que seria $o$ antepenúltimo gabinete ministerial da monarquia. Seguiu-se a ele, outro gabinete conservador, o de João Alfredo, responsável pela abolição dos escravos, para finalmente voltarem ao poder os liberais, com o gabinete ministerial do visconde de Ouro Preto, aquele que à maneira de estopim serviu para deflagrar a revolução republicana de 1889.

Se durante todo o tempo que Ramalho Ortigão esteve no Brasil, foi o barão de Cotegipe o comandante do poder executivo, o poder moderador, por sua vez, foi comandado pela princesa Isabel, que desde 30 de junho de 1887, com a viagem à Europa de seu pai para tratamento de saúde, principiara a sua terceira e última regência. Cotegipe acumulou, juntamente com o cargo de presidente do conselho de ministros a Pasta dos Negócios Estrangeiros, desde o início, e a partir de setembro de 1887, quando Ramalho já se encontrava no Brasil e a ele foi apresentado, igualmente a Pasta do Império.

Mas, não obstante tanta centralização de poder, havia concedido a direção da Pasta da Agricultura ao senador Antônio da Silva Prado, membro desta ilustre família paulistana, irmão de Eduardo Prado $^{200}$, o dileto amigo brasileiro de Eça de Queirós e também de Ramalho Ortigão.

\footnotetext{
${ }^{199}$ A primeira carta enviada por Ramalho Ortigão foi publicada no dia 12 de julho de 1877.

${ }^{200}$ Paulo Prado, autor de Retrato do Brasil, primogênito de Antônio, era apenas nove anos mais novo que o tio Eduardo e, como ele, assíduo freqüentador da casa de Eça de Queirós, como revelou a René Thioller, o elegante cronista da antiga sociedade paulistana.

"Imagine você! Eu moço, com dinheiro no bolso, em Paris, assediado pelas mulheres, em vez de me deixar arrastar por elas, preferia ir a Neuilly, ouvir o mestre. Não vá supor que ele discursava, não. Isso seria bom para a caipirada aqui da nossa terra. Ele palestrava. E com que finura palestrava, com que humour!... A mim, o palestrador me
} 
Apesar de ter sido senador, ministro e conselheiro de Estado no Segundo Império, Antônio Prado foi dos primeiros monarquistas a aderir à república, tendo publicado, logo após o 15 de novembro, um manifesto de apoio incontinente ao governo provisório. Além disso, quando em 1895 se fundou um partido monarquista em São Paulo e se articulou um movimento restaurador, encabeçado justamente pelo seu irmão Eduardo, fez publicar nas páginas de $O$ Estado de São Paulo e reproduzir nas da Gazeta de Notícias uma declaração pública que representou um verdadeiro balde de água fria no ânimo dos monarquistas que sonhavam com a sua adesão. Em texto claro e incisivo, direto e sem meias palavras, Antonio Prado categoricamente afirmou sua descrença no movimento, considerando contraproducente e até mesmo impatriótica a tentativa de restauração de um regime que a seu modo de ver e vai na afirmação um tanto de autocrítica - acabou pela imperícia dos homens que o comandavam e pela fragilidade dos alicerces em que se baseava.

Confessando ter feito a contragosto a declaração (resposta a insistentes perguntas de amigos), ele confirma e sustenta a posição adotada desde novembro de 1889 de total afastamento e abstenção das lides políticas, uma atividade que embora lhe tivesse tomado mais de trinta anos de vida não Ihe havia deixado, garantia ele, saudade alguma ${ }^{201}$.

Mas foi justamente no ano da visita ao Brasil de Ramalho Ortigão que Antônio Prado alcançou uma cadeira vitalícia no Senado e seu irmão, Caio Prado, foi nomeado presidente da província de Alagoas, satisfazendo um desejo de dona Veridiana - a matriarca do clã - de afastar este filho da suposta influência da roda boêmia da cidade de São Paulo.

É ainda deste mesmo ano da viagem uma carta enviada em 14 de junho por Eça de Queirós a Ramalho Ortigão, na qual o antigo colaborador de

parecia superior ao escritor..." (René Thiollier, Episódios de minha vida, in Carlos Berriel,

Tietê, Tejo e Sena: a obra de Paulo Prado, p. 30)

Salvo algum exagero, as palavras de Paulo Prado servem como testemunho desta qualidade inerente à pessoa de Eça de Queirós, conhecida dos íntimos e já destacada em outras páginas deste trabalho.

${ }^{201}$ Conquanto também estivesse afastado da vida pública, Joaquim Nabuco não comungava dessa mesma opinião, como se pode deduzir de uma entrevista concedida a Luís de Castro, publicada pela Gazeta de Notícias um dia após a declaração de Antônio Prado.

"Parece-me natural que um grupo de homens que pensam e sentem do mesmo modo e formam uma sociedade à parte aspirem ao direito de justificar publicamente a sua abstenção, e até de associar-se para votarem uniformemente, se chegar o dia de irem às urnas." (Gazeta de Notícias, 12 de novembro de 1895) 
As farpas, curioso, queria saber exatamente o dia em que o amigo partiria "na caravela, a redescobrir o Brasil"202.

O dia exato em que deixou o porto de Lisboa o vapor francês em que Ramalho Ortigão embarcou com a mulher e a filha, Maria Feliciana, rumo à terra dos "papagaios" não se sabe ao certo. O que se sabe com exatidão é que ele passaria por Salvador no dia 4 e desembarcaria o ilustre viajante no Rio de Janeiro na tarde do dia 7, um domingo do mês de agosto do ano 1887. Neste mesmo dia, a Gazeta de Notícias, assim que recebeu a confirmação da chegada do Sénégal, o vapor francês, afixou um boletim à porta de seu escritório avisando aos interessados a provável hora de sua entrada na barra do Rio de Janeiro, alugou uma lancha e pôs no cais do Pharoux à disposição dos que desejassem ir a bordo receber seu correspondente.

Assim que se anunciou a entrada do vapor na baía da Guanabara, outras lanchas, além daquela alugada pela Gazeta de Notícias, partiram do cais levando comerciantes, jornalistas, parentes e artistas para bordo do navio francês, que todos desejavam cumprimentar o escritor.

Depois de cumprimentado pela multidão que o recebeu a bordo, Ramalho Ortigão foi, com a esposa e a filha, conduzido na lancha de seu irmão até o cais Pharoux, onde uma grande agitação de curiosos aguardava o seu desembarque. Este irmão de Ramalho, o comendador Joaquim da Costa Ramalho Ortigão, era um abastado comerciante da praça do Rio de Janeiro, onde há algum tempo vivia e desfrutava de grande consideração e respeito. Foi em sua casa, no bairro do Cosme Velho, que Ramalho se hospedou com a mulher e a filha durante todo o tempo que permaneceu no Brasil.

A calorosa recepção de que foi objeto o escritor era fruto, sem dúvida alguma, da admiração, do apreço e da estima que gozava no país visitado, onde eram poucos os escritores que podiam se vangloriar de tamanha popularidade. A consideração era tanta que havia mesmo quem chegasse a acreditar que fosse mais estimado no Brasil, onde "começou por conquistar

\footnotetext{
${ }^{202}$ Eça de Queirós, Correspondência, p. 131.
} 
simpatias e acabou por impor-se à admiração de todos" 203 , do que propriamente em Portugal, um país que por tanto amar tanto criticou.

Seis dias depois de sua chegada, o jovem poeta e jornalista Luís Murat, do grupo de Olavo Bilac, Raul Pompéia, Aluísio Azevedo e Pardal Mallet, publicou uma crônica na Gazeta de Notícias, saudando o visitante. Como era de se prever, o artigo do jovem jornalista era um preito de admiração ao escritor português, com muitos elogios ao seu estilo e aos métodos por ele adotado, tributo que seguia o diapasão comum a outros trabalhos da época. Dois tópicos desta crônica valem a pena ressaltar: um que diz respeito aos imitadores do escritor, as "caricaturas" de Ramalho Ortigão como diz Murat, o que não deixa de ser uma informação preciosa por revelar o grau de penetração e a influência por ele exercida na imprensa periódica brasileira; e outro que diz respeito ao seu dom de grande observador dos povos que visita, com anotações e apontamentos de impressões deixadas em seu espírito que muitas vezes resultam em obras que tão bem registram "os sentimentos, a índole, o temperamento, os gostos, os hábitos de cada povo"204. Entre elas Luís Murat destaca especialmente o livro A Holanda, por ele considerado "obra prima de estilo, de análise, de história, de psicologia e de moral”205.

Levando ainda em consideração a "originalidade de ponto de vista”, Murat, nesta crônica, deixa implícito o que em outros textos está explicitado, e que vem a ser a grande expectativa vivida pelo mundo letrado brasileiro, em função desta visita de Ramalho que fez com que todos passassem a sonhar com um livro sobre o Brasil, um trabalho assim ao molde do que já havia feito com a Holanda, país que visitou em 1883 e sobre o qual escreveu uma série de folhetins para a Gazeta de Notícias. Foi da recolha destes folhetins publicados pelo diário brasileiro na seção denominada "Notas de Viagem" que resultou a obra editada em 1885 com o título de A Holanda $^{206}$.

\footnotetext{
${ }^{203}$ Gazeta de Notícias, 7 de agosto de 1887.

${ }^{204}$ Idem, 13 de agosto de 1887.

205 Ibidem.

${ }^{206}$ Um exemplar desta obra foi oferecido a D. Pedro II pelo autor que o fez acompanhar de uma carta datada de Lisboa, 27 de agosto de 1885, um documento particularmente revelador de quanto Ramalho se considerava comprometido com a imprensa brasileira. Veja-se, por exemplo, o que ele diz do Brasil: "um país em cuja imprensa eu tenho a honra de haver conquistado pelo trabalho exercido nas mais benéficas
} 


\section{1 - O livro sobre o Brasil}

Não há dúvida de que realmente houve da parte de Ramalho o propósito de escrever uma obra sobre o Brasil. Se já trazia esta intenção desde a partida de Lisboa, ou se a idéia the ocorreu depois que chegou ao Rio de Janeiro e tomou conhecimento da grande expectativa criada em torno dela, é uma pergunta cuja resposta pouca importância teria, além de não vir ao caso agora.

Importante mesmo é saber que pouco mais de um mês depois de seu desembarque era inaugurada a sede própria do Gabinete Português de Leitura, nesta época presidida pelo seu irmão Joaquim. A festa de inauguração que comemorava também o cinqüentenário daquela instituição foi imponente e concorrida, contando com a presença de personalidades ilustres como a princesa Isabel, regente do trono, e de seu marido, o conde d'Eu, de membros do gabinete Cotegipe, de políticos do Senado, da Assembléia Legislativa e da Câmara Municipal, do corpo diplomático português e brasileiro e de "grande número de senhoras, literatos, jornalistas, comerciantes e artistas" ${ }^{207}$. Como se vê, o que havia de mais representativo na sociedade do Rio de Janeiro, da época, prestigiou as festividades deste centro de cultura.

Pois bem, nesta solenidade, ocorrida no dia 10 de setembro e que se constituiu em um verdadeiro acontecimento cívico daquele ano de 1887, Ramalho Ortigão foi um dos oradores e o seu discurso, assim como o de seu irmão e o do representante da embaixada portuguesa no Brasil, foram todos integralmente reproduzidos pela Gazeta de Notícias na edição do dia seguinte.

O discurso do representante da embaixada de Portugal no Brasil destacava o trabalho e a ação dos portugueses imigrantes na elevação intelectual do povo do país que os acolheu, numa clara alusão à biblioteca por eles fundada; o discurso de seu irmão louvava o espírito de associação de maneira geral e particularmente o espírito associativo dos fundadores do

condições de independência intelectual os direitos de naturalização literária”. (Rodrigues Cavalheiro, $A$ evolução espiritual de Ramalho, p. 458)

${ }^{207}$ Gazeta de Notícias, 11 de setembro de 1887. 
Gabinete Português de Leitura e o seu punha em destaque aquilo que considerava os dois principais legados da civilização portuguesa ao Brasil: a língua e a escravidão.

A língua chegou naturalmente com os primeiros colonizadores e a escravidão, após o fracasso com os nativos, foi trazida da África com o objetivo de "fundar o trabalho, organizar a propriedade e criar a riqueza"208. Conquanto assim fosse, trazia em seu bojo, segundo Ramalho, alguns efeitos danosos à civilização brasileira por desacreditar o espírito de disciplina e desonrar o trabalho nos homens livres - idéias que serão posteriormente desenvolvidas em "O quadro social da revolução no Brasil". Mas, ao contrário deste contundente ensaio que tanto desgosto causou, o discurso proferido na inauguração da sede própria do Gabinete Português de Leitura não deixa de ser favorável à realidade brasileira, servindo assim de massa e fermento à expectativa da classe letrada para o livro sobre o Brasil.

Veja-se, por exemplo, nesta passagem de seu discurso, se não é mesmo um tanto quanto otimista e alentadora a impressão que lhe causava o povo e o país que ora visitava e conhecia:

O simples aspecto da sua capital, os seus monumentos, os seus antigos bairros, algumas das suas formas de construção, os seus costumes domésticos, as suas tendências de literatura e de arte, a profunda sensibilidade meiga, enternecida e saudosa dos seus incomparáveis poetas, demonstram da mais evidente maneira às curiosidades da crítica que o Brasil, apesar dos elementos tão heterogêneos que nele travam o conflito da concorrência na luta pela vida, não é - como de outros agregados de constituição semelhante se poderia dizer - uma vasta colônia internacional, submetida ao regímen cosmopolítico de um poder local. ${ }^{209}$

E não paravam por aí as considerações de Ramalho. Afirmava ele categoricamente que o Brasil, mais que uma nação, era uma verdadeira pátria para todos aqueles que nele nasciam e se criavam. Terra acolhedora, larga e

\footnotetext{
${ }^{208}$ Ibidem.

${ }^{209}$ Ibidem.
} 
generosa que o tempo sulcou, como em um velho rosto, "o expressivo e fecundo vinco da ternura e do carinho de uma velha mãe"210.

Estas idéias, julgamentos e concepções, por ele desenvolvidas e a outras acrescentadas, não poderiam resultar em uma obra, por todos os modos, satisfatória e aprazível ao gosto médio do público-leitor brasileiro? Era isto essencialmente o que permitia conjeturar este discurso proferido por Ramalho Ortigão no Gabinete Português de Leitura, uma instituição à qual estava ligado por vínculos muito estreitos e já antigos.

Desde mais ou menos dez anos atrás, seu irmão Joaquim era membro de sua diretoria e quando do lançamento, em 1880, da pedra fundamental do edifício que ora se inaugurava ele e Eduardo de Lemos, então presidente, foram os dois que mais contribuíram para a celebração do Centenário de Camões, no Rio de Janeiro, em estreita relação com Ramalho que foi quem "propôs, redigiu, explicou e defendeu perante a assembléia dos escritores de Lisboa o programa do cortejo cívico do jubileu camoniano"211.

E foi justamente Ramalho - dois dias após a morte de Eduardo de Lemos, ocorrida na manhã 14 de outubro de 1884, em um hotel de Viana do Castelo, onde também se hospedava - quem, depois de acompanhar o corpo do falecido presidente até o cemitério daquela localidade, contou para a Gazeta de Notícias tudo o que se passou desde aquela manhã luminosa de princípio do outono até a manhã do dia seguinte quando o corpo de Eduardo de Lemos foi levado a repousar no cemitério de Santo Antônio, em pleno litoral minhoto, como sempre foi de seu desejo. Com a sua morte, assume a presidência do Gabinete Português de Leitura do Rio de Janeiro ninguém mais nem menos que o próprio irmão de Ramalho, o comendador Joaquim da Costa Ramalho Ortigão.

Por essas e outras é que não se pode ter como despropositada a vinculação da viagem do escritor ao Brasil com a inauguração do imponente edifício de estilo manuelino projetado pelo arquiteto português Rafael de Castro. Não teria sido o convite do irmão para discursar na solenidade de

\footnotetext{
210 Ibidem.

${ }^{211}$ Ramalho Ortigão, As farpas VI, p. 103.
} 
inauguração a razão pela qual tenha aceitado viajar em companhia da mulher e da filha, algo que não era muito comum acontecer? Embora muitas vezes contrariasse a esposa, Ramalho tinha por hábito e gosto viajar quase sempre sozinho, mas como desta vez não se tratava exatamente de uma viagem de trabalho... E pode ser que, conquanto não tivesse deixado Lisboa com propósito algum firmado, ao perceber o interesse despertado e a facilidade proporcionada pelos amigos brasileiros, houvesse então lhe ocorrido a idéia e a possibilidade da elaboração de um livro sobre o Brasil.

Esta hipótese é respaldada pela seguinte circunstância que envolvia a obra: logo após o seu desembarque, Ramalho Ortigão escreveu uma carta ao genro Eduardo Burnay ${ }^{212}$ comentando a viabilidade deste livro sobre o Brasil ser editada em parceria com os comerciantes portugueses estabelecidos na praça do Rio de Janeiro, os quais the garantiam, por aquisição antecipada, as duas primeiras edições, num total de cinco mil exemplares. Esta proposta que Ihe foi apresentada pelos amigos de seu irmão resumia-se no seguinte: compravam-Ihe a primeira e segunda edição do livro, respectivamente, de dois e de três mil exemplares, sendo que as despesas da primeira edição correriam por conta do autor e as da segunda por conta dos comerciantes. Além de comprarem as edições em livro ainda lhe davam o direito de publicação antecipada do texto em extratos ou fascículos no jornal que melhor lhe conviesse, fosse qual fosse, português ou brasileiro.

Era evidente que a proposta dos comerciantes garantia o sucesso do empreendimento e só poderiam servir de incentivo a um autor que, como se sabe, tem nos relatos de viagem boa parte de sua obra. Por toda a vida Ramalho foi um apaixonado pelas viagens e delas tinha sempre como objetivo o registro daquilo que via e conhecia: paisagens, personagens, praças, habitações, máquinas, equipamentos, objetos artísticos e tudo o mais.

E a sua real intenção de escrever um livro sobre o Brasil é reafirmada por outra carta, esta endereçada ao amigo Eduardo Prado, quando então, após conhecer os pampas gaúchos e provar a vaquillona e o puchero na

\footnotetext{
${ }^{212}$ Rodrigues Cavalheiro, A evolução espiritual de Ramalho, p. 446.
} 
estância El Carmen de Estanislau Zeballos, já havia retornado a Portugal. Entre outras coisas, ele faz a seguinte revelação ao amigo brasileiro:

Leia como puder estas linhas feitas a trouxe-mouxe, e não as mostre a ninguém, porque dentro delas, competentemente cheios todos os espaços, está também todo o meu livro, cuja primeira impressão me não convém desflorar. ${ }^{213}$

Mas, além destas duas cartas, tem-se também como evidência dessa intenção de Ramalho uma troca de correspondências com sua esposa, dada em meados de 1889, documentos que servem para demonstrar que, ao menos em família, ainda se achava viva a idéia da projetada obra.

À esposa que se achava em Portugal, dizia de Paris Eça de Queirós que seu amigo de tantas jornadas vivia naquela cidade inteiramente entregue "dans les folles aventures",214. Provavelmente chegou aos ouvidos da Emília, mulher de Ramalho que também se achava em Portugal, referências a este comportamento e alguns ecos da música executada nos salões por ele freqüentados, principalmente, o salão residencial da atriz Sarah Bernhardt. Naturalmente atiçada pelo ciúme, ela prontamente lhe envia uma carta em que, além de revelar o grau de desassossego em que vivia, fazia uma série de cobranças e questionamentos, principalmente a respeito do andamento do livro sobre o Brasil.

Sempre em nome do convencimento, Ramalho, na longa carta enviada como resposta à esposa, usa e abusa de sua capacidade de aduzir raciocínios e apresentar argumentos, pondo a serviço um verdadeiro torneio silogístico pleno de inferências e deduções que, tudo somado, não passava de um evidente esforço no sentido de devolver o sossego ao espírito da esposa ressabiada e, principalmente, tranqüilizá-la quanto às suas relações de amizade com a famosa atriz Sarah Bernhardt.

\footnotetext{
${ }^{213}$ Cartas da biblioteca Guita e José Mindlin, p. 64.

${ }^{214}$ Ramalho Ortigão, Cartas a Emilia, p. 72.
} 
Tranqüiliza-te completamente sobre esse ponto. Se as minhas relações com esta minha amiga fossem mais íntimas do que o permitido ninguém aí saberia que eu freqüento a casa dela. ${ }^{215}$

Mas, a despeito de toda boa argumentação e de todo empenho por ele revelado no convencimento da esposa, a real impressão que fica da leitura desta carta é a de que ele vivia mesmo é dans les folles aventures. Eram jantares, concertos, soirées, apresentações, bailes, enfim, uma agenda repleta de atividades comuns a um círculo social ao qual não faltavam artistas, cientistas, políticos, jornalistas, amigos brasileiros, entre os quais Eduardo Prado, Santana Nery e o barão do Rio Branco e amigos portugueses, principalmente, alguns do grupo dos Vencidos da Vida, residentes ou de passagem por Paris: Eça de Queirós, Carlos Mayer, conde de Ficalho e Jaime Batalha Reis.

É com muito orgulho que cita o fato de Coquelin ter mandado traduzir para o francês um artigo seu publicado na Gazeta de Notícias ${ }^{216}$. Vaidoso, conta à esposa que o ator francês lia a tradução para alguns colegas da Comédie Française e sempre que se encontravam no saguão desse teatro era por ele apresentado aos amigos como um "crítico ao qual apenas dois ou três em França se podem comparar"217.

E quanto à obra sobre o Brasil, alegava que vinha nela trabalhando de uma a duas horas todos os dias e que tinha encontrado na biblioteca particular dos amigos brasileiros residentes em Paris uma série de informações que não havia obtido em sua passagem pelo Rio de Janeiro. Taxativo, põe termo ao assunto e categoricamente diz à esposa:

O livro do Brasil (descansa sobre esse ponto, que é hoje para mim mais que nunca capital) não só se há de fazer, mas há de ser o melhor de todos os livros que eu tenho feito. ${ }^{218}$

\footnotetext{
${ }^{215}$ Ibidem, p. 70.

${ }^{216}$ Trata-se de um artigo ainda inédito em livro, intitulado Coquelin e Sarah Bernhardt, publicado pela Gazeta de Notícias no dia 10 de junho de 1888.

${ }^{217}$ Ramalho Ortigão, Cartas a Emília, p. 71.

${ }^{218}$ Ibidem, p. 70.
} 
E para melhor firmar e confirmar a alegação cita os encontros com Eduardo Prado, com o barão do Rio Branco, com Sant'Ana Nery diplomata e escritor paraense - aos quais reputava mais conhecedores do Brasil que todas as pessoas juntas encontradas em sua passagem pelo país.

Certamente estes brasileiros constituíam um apoio inestimável, pois é de conhecimento geral que Eduardo Prado, por exemplo, possuía uma riquíssima biblioteca pronta para satisfazer qualquer pesquisador interessado em conhecer a realidade brasileira, e que por sua vez o barão do Rio Branco havia coligido um volume substancial de documentos sobre o Brasil $^{219}$, além de ser ele mesmo um verdadeiro acervo ambulante de brasilidades.

No entanto, esta tão esperada obra jamais foi publicada. Talvez nem mesmo tenha sido iniciada, a despeito de toda a alegação feita e de toda facilidade com que contava para sua realização. Poderia, por exemplo, ter viajado outras vezes, conhecido melhor o país e sua gente, seus modos, costumes, habitações, principalmente as habitações, para cuja visitação teria encontrado muito mais facilidade do que aquela que encontrou em sua passagem pela Holanda. Ninguém se negaria a abrir-lhe a porta e para muitos seria mesmo uma questão de honra, associada à alegria e ao prazer o recebêlo em casa. Poderia ter conhecido muito melhor a agricultura e a pecuária, o comércio interno e externo, a pequena indústria, os meios de transportes, a forma de governo, enfim tudo o que necessitasse para realizar a empreitada.

Poderia, mas não fez, e o livro sobre o Brasil jamais veio a lume e foi isto uma pena, além de grande frustração para o leitor brasileiro que havia tido o privilégio da primeira leitura dos folhetins sobre a Holanda e ansioso aguardava a ocasião de folhear um trabalho semelhante a respeito de seu país.

\footnotetext{
${ }^{219}$ Foi justamente valendo-se desse material adquirido ao longo do tempo - mapas, cartas e documentos raros - que Rio Branco elaborou as suas memórias por ocasião das disputas territoriais em que o Brasil esteve envolvido e foi ele seu advogado. Acredita-se que Ramalho Ortigão - pela facilidade que lhe proporcionava o cargo na Real Biblioteca da Ajuda - tenha colaborado na reunião deste material.
} 


\section{2 - A Holanda na Gazeta de Notícias}

Viajando na "qualidade de correspondente"220 da Gazeta de Notícias, Ramalho Ortigão chegou à Holanda, via Wiesbaden, em meados de agosto de 1883. Alojando-se em casa de família, em um pequeno quarto devoluto de um estudante em férias, logo ao fim deste mês envia o primeiro trabalho sobre o país e será este o primeiro de uma série de mais de cinqüenta textos, publicados pelo jornal, não na conhecida seção das "Cartas Portuguesas", mas na secção intitulada "Notas de Viagem", procedimento semelhante ao que já havia tomado em relação aos textos enviados pelo escritor em 1878 sobre a Exposição de Paris. Naquela oportunidade, o nome da seção acabou servindo para o título do livro que resultou da recolha daqueles folhetins, assunto este de comentários anteriores.

Os textos sobre a Holanda publicados no jornal foram, como no livro, subdivididos em oito tópicos, porém as denominações não são rigorosamente as mesmas. No caso específico do jornal, que é o que ora interessa, a seqüência apresentada recebeu a seguinte denominação: As origens, Os aspectos exteriores, A paisagem, As cidades, As casas e os indivíduos, As colônias neerlandesas, A crítica holandesa e A arte holandesa.

O primeiro destes textos sobre a Holanda foi publicado pela Gazeta de Notícias em 10 de outubro de 1883 e o último a 11 de setembro de 1885. A simples equiparação das datas revela que estas "Notas de Viagem" andaram pelas páginas do jornal por um período de quase dois anos, muito embora não seguisse a sua publicação uma seqüência rígida e ininterrupta. Sempre que fosse o caso, o folhetinista se interpunha entre elas e abordava outros temas, tratando de novidades ou acontecimentos relevantes que de maneira geral sempre interessavam a leitores de jornal. É o que acontece, por exemplo, com a morte de seu amigo Jerônimo Colaço de Magalhães.

Diante deste fato, Ramalho interrompe uma rigorosa seqüência de vinte e uma "Notas de Viagem" para dar lugar a um longo folhetim intitulado

${ }^{220}$ Ramalho Ortigão, A Holanda II, p.100. 
"Confidência triste da vida alegre", que o jornal subdividiu em três partes e fez publicar na secção das "Cartas Portuguesas". Tanto a confidência triste quanto a vida alegre, que em algum momento ele compartilhou, diz respeito a este seu amigo que acabava de falecer em Paris. Na pena do folhetinista, este personagem real - um dandy português que trocou toda a sua fortuna por uma ostentosa vida parisiense, repleta de lances de espírito, de duelos de espada e de amores proibidos - assume, em certos momentos, foros de personagem de fiç̧ão e lembrando o romance queirosiano faz com que haja mesmo quem assegure haver em Carlos Fradique Mendes muitos traços característicos daqueles apontados por Ramalho em Jerônimo Colaço de Magalhães.

Após estas "Cartas Portuguesas", intercaladas entre a paisagem e as cidades holandesas, tem-se, então, uma seqüência ininterrupta de vinte e cinco "Notas de Viagem" que esgotam o tema sobre as cidades e dá início àquele que trata das casas e dos indivíduos.

A esta altura, os textos sobre a Holanda que, como foi visto, principiaram a aparecer nas páginas do diário brasileiro em meados de outubro de 1883 já tocavam pelos fins de setembro do ano seguinte. Aí por esta época principia uma longa série de "Cartas Portuguesas" que só vai se encerrar no segundo semestre de 1885, quando então Ramalho retoma o tema e publica as últimas "Notas de viagem" sobre o país dos diques e dos moinhos. São onze textos comentando alguns aspectos das colônias e da arte holandesa.

Especialmente escritas para a Gazeta de Notícias, estas notas sobre a Holanda foram, ainda neste ano de 1885, recolhidas em livro, por muitos considerado a sua obra-prima. Singela e modestamente, Ramalho o define como uma "pintura sincera e comovida dos velhos lares holandeses, tão simples, tão modestos, tão recolhidos e tão meigos" ${ }^{\text {"21 }}$.

A sua permanência por um período de mais ou menos três meses naquele país foi o suficiente para que pudesse observar e anotar o que de mais significativo nele existia, proporcionando ao leitor brasileiro uma justa e bem

\footnotetext{
${ }^{221}$ Ramalho Ortigão, prefácio à terceira edição de $A$ Holanda.
} 
formada idéia da índole e dos costumes daquele povo ${ }^{222}$. Para isso, percorre os campos e as aldeias, observando as casas simples e rústicas, com sua cozinha, seus móveis e seus utensílios; passeia pelas cidades observando os parques e seus jardins, os museus e suas coleções artísticas, os clubes, as escolas, as fábricas; vai a corridas de cavalos e a praias de banho. Descreve e compara casas de campo e casas de cidade, interiores de artistas e interiores de burgueses; comenta a educação das crianças e a hospitalidade das famílias, o sentimento democrático do povo, o espírito rotineiro, o culto da tradição e o respeito ao trabalho.

Após a referida longa série de "Cartas Portuguesas" que duraram mais de oito meses, Ramalho retoma o tema da Holanda e o jornal publica os seis últimos textos sobre o assunto, no segundo semestre de 1885. Tanto tempo decorrido com seus textos sendo publicados naquela secção que estas últimas "Notas de Viagem", por esquecimento ou descuido do paginador, acabaram saindo mesmo como "Cartas Portuguesas". Todas tratam da arte em geral: a pintura, a escultura, o mobiliário, a latoaria, a tapeçaria, a ourivesaria, a arquitetura, mas entre elas elege, enfatiza e põe em destaque particularmente a pintura holandesa. Ramalho, no intuito de situá-la dentro do contexto universal, faz uma análise sucinta, mas muito esclarecedora, do comportamento das artes plásticas ocidentais no que diz respeito ao objeto, assunto ou tema comuns que orientavam os interesses dos artistas e demonstra exemplarmente o caráter inovador e o papel preponderante exercido pela pintura holandesa sobre os artistas de outros países quanto ao aspecto temático. Quando ainda era simbólica toda expressão da pintura que se fazia nas monarquias católicas, a Holanda protestante, democrática e republicana, onde não se cultuavam imagens bíblicas, nem ídolos pagãos, nem tampouco era a arte subjugada pelos soberanos, nobres e eclesiásticos que povoavam os trabalhos dos artistas daqueles países, a temática da pintura holandesa já havia voltado seus olhos para os mais singelos e prosaicos aspectos da vida cotidiana. Daí o profundo desdém com que algumas das mais tradicionais academias européias olhavam para a pintura praticada na Holanda.

\footnotetext{
222 "A Holanda foi traduzida e dada a conhecer às crianças holandesas, numa edição escolar" ("Ramalho Ortigão por Luís da Câmara Reis”, in Perspectiva da literatura portuguesa do século XIX, p. 408).
} 
Que horror nos mestres que só pintavam deusas e ninfas, paraísos e apoteoses, príncipes e princesas, perante as cozinhas de Kalft, em que a figura principal é uma escumadeira ou um tacho, uma velha barrica, uma vassoura, um molho de espargos ou de cebolas! ${ }^{223}$

Ainda no terreno da pintura, comenta, com propriedade, as telas Ronda da noite, Lição de anatomia e Os síndicos de Rembrandt, trazendo para objeto de discussão os comentários feitos, a propósito destas obras, por Theophile Gautier, Gustave Planche, John Reynolds, Charles Blanc, Viardot, Fromentin, revelando, assim, com esta pequena bibliografia, o cuidado tomado para falar sobre o assunto, um procedimento comum na elaboração de seus textos.

Resumindo suas impressões sobre tudo o que viu de pintura na Holanda, Ramalho, com ousadia e coragem, afirma categoricamente que "a fórmula naturalista da arte moderna acha-se inteiramente enunciada depois de duzentos anos na obra dos pintores holandeses"224. Além do mais, tinha Franz Hals na conta de "mestre incontestado e supremo de todo o moderno pintor de figura"225, o que, segundo ele, era a opinião de quantos conheciam a obra do pintor, pertencente ao acervo do museu do Haarlem.

A curiosidade própria dos que amam as viagens e se interessam por políticas comparadas levou Ramalho até ao programa colonial da Holanda. Aí observou as relações da metrópole com as colônias localizadas principalmente no oceano Pacífico, que, assim como as colônias portuguesas, constituíam uma espécie de extensão do país, composto de feitorias e possessões espalhadas pela Ásia, numa extensão de quase trinta mil milhas quadradas para um país cuja extensão territorial não ia além de seiscentas e quarenta milhas. Quer isto dizer que o território das colônias asiáticas era quase cinqüenta vezes maior que a própria Holanda, e ela ainda contava com as possessões americanas.

\footnotetext{
${ }^{223}$ Ramalho Ortigão, A Holanda II, pp. 226, 227.

${ }^{224}$ Ibidem, p. 225.

${ }^{225}$ Ibidem, p. 225.
} 
Qualquer informação podia ser obtida sem necessidade alguma de arredar o pé de Amsterdã, pois tudo o que alguém desejasse saber sobre Java, Sumatra ou Suriname, em seus aspectos naturais, sociais ou administrativos, estava disponível nos catálogos da seção reservada às colônias da Exposição Universal de Amsterdã.

Quando em 1885 se fez a recolha dos textos publicados pela Gazeta de Notícias para a edição em livro do material sobre a Holanda, Ramalho Ortigão acrescentou à obra um novo capítulo sobre a cultura intelectual do país. Nele, traça um pequeno paralelo entre a organização portuguesa e a organização holandesa de ensino público e a mais simples comparação serve, como ele diz, para deixar qualquer representante da crítica portuguesa a um tempo "inteiramente assombrado e confundido de admiração"226 pela organização da instrução pública na Holanda e inteiramente perplexo e sufocado de preocupação pela organização da instrução pública em Portugal.

Ainda neste capítulo, observa o processo de formação de professores e o funcionamento daquilo que denominavam "estudo instituído", algo semelhante a um movimento estudantil responsável pela criação de uma rede de relações que estabeleciam vínculos de espírito capazes de atuar no desenvolvimento intelectual do aluno e na formação do caráter do cidadão. Diante de toda a eficiência e de todo desenvolvimento visto na Holanda, só podia mesmo lamentar o descaso em que se encontrava relegado o ensino em Portugal.

Com este capítulo que intitulou "A cultura intelectual", Ramalho põe um ponto final neste trabalho que pode servir de modelo dos livros de viagens deixados pelos realistas. Como se sabe, os realistas, ao contrário dos românticos - subjetivos até em descrições de ambientes ou paisagens primavam pelo intuito de objetividade em seus trabalhos e em nome dela armavam-se do mais apurado senso prático para observar criticamente, sempre no sentido de educar e reformar as sociedades. É simples e fácil compreender que nesse caso específico a sociedade a ser reformada só

${ }^{226}$ Ibidem, p. 238. 
poderia ser a de seu país. Em viagem, fazia parte do seu processo de trabalho estabelecer contrapontos e é por isso que ao folhear este livro o leitor vai se deparar constantemente com a realidade portuguesa, a todo o momento surgindo em comparações, sugestões e análises.

Viajando e falando de suas viagens, Ramalho procedia como um verdadeiro homem de ciência interessado em questões de Sociologia Comparada, prontamente aberto e sempre à procura de temas e assuntos que levassem ao conhecimento de princípios e noções que pudessem auxiliar o bom desempenho de uma organização social.

E sendo assim, para comparação com Portugal, qual país melhor do que a Holanda, com sua tradição marítima e seu destino comercial? Uma nação civilizada, próspera e independente, governada com tanta sabedoria e discernimento que infundia respeito e admiração no crítico português.

Uma das coisas que me trouxeram à Holanda foi o desejo de molhar neste caldo de independência uma côdea da minha broa natal, foi a curiosidade de aprender no exemplo de um pequeno povo heróico a retemperar em mim próprio contra as nevroses da minha raça o respeito das virtudes obscuras e o amor das coisas simples. $^{227}$

O estilo claro e incisivo, o elevado sentimento moral que ditou toda a elaboração do livro, o resultado obtido nas descrições de paisagens, de interiores, de maquinismos típicos desse país, como os moinhos e os diques para cujo funcionamento este povo se mantém alerta, levaram Fidelino de Figueiredo a considerar o livro, $A$ Holanda, "não só uma obra de arte, mas uma boa ação"228.

\footnotetext{
${ }^{227}$ Idem, A Holanda I, p. 44.

${ }^{228}$ Fidelino de Figueiredo, História da literatura realista, p. 276.
} 


\section{3 - A expectativa do leitor brasileiro}

Estas "Notas de Viagem" publicadas pela Gazeta de Notícias a partir de 1883; a viva lembrança do livro que delas resultou, editado em 1885, e a visita do escritor ao país, ocorrida em 1887, constituem uma seqüência progressiva de datas e fatos que por si só resultaria na criação de uma grande expectativa e não havia quem pudesse considerar infundadas as esperanças dos brasileiros de que ele produzisse sobre o país uma obra, senão melhor, ao menos tão boa quanto aquela que escreveu sobre a Holanda. Como já foi observado, dispunha ele de todas as facilidades, de todas as garantias editoriais e nenhuma informação Ihe seria negada. Encontraria uma legião de admiradores dispostos a recebê-lo em casa ou servir-lhe de companhia nas ceias pelos restaurantes da moda, sugerindo-lhe os pratos e disputando a honra de arcar com as despesas.

Um cronista da Gazeta de Notícias ouviu de um amigo que acompanhava o escritor que Ramalho Ortigão, nos sete primeiros dias de visita ao Brasil, travou conhecimento com 2157 pessoas, o que resultava "uma média de trezentos e tantos conhecidos por dia",229.

Ferreira de Araújo reuniu em sua residência, para um banquete em homenagem ao seu correspondente, alguns dos principais representantes do jornalismo brasileiro, além de importantes políticos da época. Compareceram a esta reunião Machado de Assis, José do Patrocínio, Artur Azevedo, Ângelo Agostini, Henrique Chaves, Luís Murat, os conselheiros Saldanha Marinho e Otaviano Nogueira, além de outros monarquistas como o senador Taunay, o barão de Paranapiacaba e Afonso Celso Júnior. Todos bons conhecedores do país em que viviam e naturalmente dispostos a auxiliar e contribuir com o escritor português para a realização de sua obra sobre 0 Brasil.

Toda esta grande expectativa acha-se muito bem caracterizada em artigos publicados pela Gazeta de Notícias do Rio de Janeiro e pelo Diário

\footnotetext{
${ }^{229}$ Gazeta de Notícias, 14 de agosto de 1887.
} 
Mercantil de São Paulo. No já referido artigo com que Luís Murat saudou, naquele jornal, a chegada do escritor, ela é patente, embora não de forma tão explícita como no texto em que a folha carioca dele se despediu. Neste o redator acredita piamente que as impressões deixadas no escritor seriam verdadeiramente traduzidas em livro que, como no caso da Holanda, seria "uma obra-prima de observação e de crítica judiciosa e ilustrada"230.

Porém, onde mais se acha patenteada toda a expectativa e a fundada esperança é no jornal paulistano Diário Mercantil, cuja primeira página da edição de domingo, 4 de setembro de 1887, foi toda tomada por artigos encomiásticos e um retrato a bico de pena do escritor com o bigode retorcido, pince-nez nos olhos e chapéu nas mãos que se apoiavam ao quadril. Dos três artigos que emolduravam o busto retratado de Ramalho, dois eram assinados: um é de Olavo Bilac e o outro é de Alfredo Pujol; mas o que melhor espelha e representa tudo o que se disse até agora é justamente a matéria sem assinatura, de responsabilidade da redação.

Principiando com os costumeiros comentários sobre a admiração e estima de que era alvo entre os jornalistas brasileiros e aludindo a uma próxima viagem do escritor à província de São Paulo, o artigo, logo após o preâmbulo, entra fundo no tema do livro sobre o país visitado.

Como se sabe, o grande crítico das Farpas veio ao Brasil expressamente para estudar de perto a nossa civilização, os nossos costumes, a nossa vida, em suma, que em breve teremos estereotipada em um livro admirável que terá por assunto o Brasil. ${ }^{231}$

E para que a obra fosse a mais verdadeira possível pedia 0 redator que nada lhe fosse ocultado, nem as "cousas boas", nem as "cousas más”, e que não ficassem sem respostas as mais insignificantes perguntas e até mesmo seus caprichos fossem satisfeitos. E só assim, ao lhe serem desvendados os costumes de família e os hábitos sociais poderia o crítico com sua sagacidade e poder de observação distinguir o povo brasileiro em geral e o

\footnotetext{
${ }^{230}$ Idem, 14 de novembro de 1887.

${ }^{231}$ Diário Mercantil, 4 de setembro de 1887.
} 
paulista em particular com uma obra "que será ao mesmo tempo um profundo ensinamento e uma glória para o Brasil"232.

Tanta e tão manifesta euforia, mesclada a patriótico ufanismo, não poderiam deixar de sensibilizar o jovem jornalista Alfredo Pujol ${ }^{233}$, que demonstrava em seu artigo um vivo interesse pela obra que, estava certo, Ramalho escreveria sobre a terra brasileira.

E agora, a visita do fecundo escritor à nossa pátria quer dizer que, dentro de pouco tempo, um editor feliz trará em reboliço os seus prelos para nos dar, o mais cedo possível, mais um fruto saboroso da extraordinária pena desse crítico notável que neste momento hospedamos; quer dizer que teremos, daqui a alguns meses, estampados nas páginas de um livro interessantíssimo, a nossa política, os nossos costumes, as facetas diversas e múltiplas do nosso caráter, os quadros majestosos da nossa natureza exuberante de vida e de fertilidade, as grandezas do nosso solo, as nossas pequeninas misérias, em uma palavra, toda a nossa civilização, vista através do cristal cintilante daquele poderosíssimo talento. ${ }^{234}$

O artigo de Bilac era, entre todos, o menos enfático em relação à expectativa do livro sobre o Brasil, sem deixar, no entanto, de demonstrar viva esperança de que Ramalho pudesse com sua obra tornar um pouco mais conhecida e talvez até um pouco mais estimada, fora de suas fronteiras, a terra que, no entendimento do jovem poeta, embora fosse "tão caluniada" ${ }^{235}$, não deixava de ser generosa e pura.

Mais de dois anos após a sua partida, ao responder ao ensaio intitulado "O quadro social da revolução brasileira", no qual Ramalho procurava dar uma interpretação pessoal da proclamação da república no Brasil, Pardal Mallet ainda falava do livro.

\footnotetext{
232 Ibidem.

233 Alfredo Pujol nasceu no mês de março de 1865 em São João Marcos, no Rio de Janeiro, mas ainda moço veio para São Paulo cursar a Faculdade de Direito e logo ingressou no jornalismo. Literariamente estreou com uma resenha sobre o romance A carne, mas ganhou foros de crítico literário com uma série de conferências sobre Machado de Assis. Faleceu em maio de 1930.

${ }^{234}$ Ibidem.

${ }^{235}$ Ibidem.
} 
No primeiro parágrafo de seu artigo-resposta, publicado pela Gazeta de Notícias nos dias 6 e 8 de março de 1890, denominado "O Brasil e Ramalho Ortigão", ele deixa explícito a expectativa ainda existente, ou que ao menos existiu, em relação á obra do crítico português.

Sem temor de erro, pode-se dizer que as classes letradas brasileiras esperavam ansiosamente a publicação das impressões pessoais de Ramalho Ortigão sobre a nossa vida nacional. ${ }^{236}$

Malograda, no entanto, resultou toda esta expectativa e o livro que se esperava de Ramalho Ortigão sobre o Brasil jamais veio a lume.

Rodrigues Cavalheiro ${ }^{237}$ considerou a proclamação da república um acontecimento fundamental e determinante no ânimo do autor. Para ele, a queda do império provocou alterações profundas no caráter daquela sociedade com a qual Ramalho havia entrado em contato dois anos antes. Daí que as observações feitas estariam totalmente desatualizadas e, uma vez que a obra deveria ser uma pintura crítica de uma sociedade cuja estrutura de governo sofrera tamanha modificação, alterando-se tão profundamente, o trabalho teria perdido completamente a sua razão de ser.

Não há porque descartar sistematicamente esta hipótese, mas é preciso também levar em consideração o longo tempo de que dispôs Ramalho para realizar o trabalho. Desde a sua partida do Brasil, em novembro de 1887, até a proclamação da república passaram-se dois anos, prazo mais que suficiente em se tratando deste autor, principalmente quando se tem em conta o trabalho que realizou quando esteve na Exposição Universal de Paris, em 1878 e na Holanda, em 1883. Ambos os casos se tratam também de viagens cujos relatos enviados à Gazeta de Notícias, foram posteriormente reunidos em livro. O primeiro deles constitui as Notas de Viagem em que Ramalho, praticamente, termina o trabalho ao fim de sua temporada na capital francesa e no caso da Holanda, onde a sua permanência, como no Brasil, foi também de três meses, tendo ele chegado em agosto ao país, já em outubro o jornal principiava a publicação dos folhetins com as suas primeiras impressões. Vê-se

\footnotetext{
${ }^{236}$ Gazeta de Notícias, 6 de março de 1890.

${ }^{237}$ Rodrigues Cavalheiro, A evolução espiritual de Ramalho, p. 446.
} 
então por aí que este prazo de dois anos foi mais que suficientemente elástico para ele falar de um país com o qual estava bem mais familiarizado e dispunha de condições muito mais favoráveis do que se supõe tenham sido aquelas encontradas na Holanda.

Conquanto em julho de 1889, na já referida carta à esposa, ele ainda falasse no livro como coisa assente e definitiva, é bem provável que naquela altura o projeto já estivesse sepultado e para isso tenham concorrido outras razões.

Já se disse que os livros de viagem de Ramalho Ortigão orientavam-se pelos princípios de Sociologia Comparada, tendo em vista o estudo de outras sociedades, de forma a servir de espelho à sociedade portuguesa, que figurava sempre nestes casos, implícita ou explicitamente, como a contraface da comparação. E neste sentido, é curioso observar que nem mesmo $A$ Holanda, escrita especialmente para a Gazeta de Notícias, o que supunha um público-leitor não português, escapou a essa regra geral. Talvez se possa argumentar que ele, ao escrever, estivesse pensando na colônia portuguesa do Rio de Janeiro. Pode ser.

Mas se a sociedade holandesa, pelo seu respeito à liberdade, pela sua sistemática organização, pela sua primorosa educação, pela sua força de vontade e disposição frente às adversidades, servia à sociedade portuguesa como um modelo a seguir no caminho do aperfeiçoamento, o mesmo não se poderia dizer em relação ao Brasil, um país imenso, formado pela união de três raças, duas das quais, por ele e outros da época, consideradas sub-raças, e que ainda apresentava um vazio populacional em grande parte de seu território. Que é que tinha a ensinar a Portugal uma sua ex-colônia que há bem pouco tempo havia adquirido o direito de governar a si mesmo, traçando, com livre arbítrio, seu próprio destino? Aos olhos de quem estava acostumado a visitar países como a França, a Holanda, a Suíça, que Ihe proporcionavam lições, o Brasil só poderia mesmo ser visitado por "curiosidades de exotismo", como ele diz na introdução a seu ensaio. E sendo assim, à luz da Sociologia Comparada, seu trabalho não teria o mesmo significado de sua obra $A$ Holanda, ainda viva na memória de seus leitores. Daí, talvez, o inesperado silêncio. 
É uma outra hipótese, que com a de Rodrigues Cavalheiro, tentam explicar o silêncio em relação a esta possível obra de Ramalho Ortigão que, como nenhuma outra de sua autoria, apresentava uma perspectiva editorial tão grande de sucesso, com garantia total de venda e leitura.

\section{4 - "O quadro social da revolução brasileira"}

Aquém, mas muito aquém mesmo da grande obra que todos esperavam, o que realmente Ramalho deixou foi um pequeno ensaio publicado na Revista de Portuga ${ }^{238}$, em dezembro de 1889 e reproduzido na Gazeta de Notícias sucessivamente nos dias 27 e 28 de fevereiro, 1 e 2 de março de 1890. A confessada intenção do autor com este trabalho intitulado "O quadro social da revolução brasileira" era contribuir para o esclarecimento de um fato (proclamação da república no Brasil) por ele considerado de capital importância para a compreensão dos novos rumos apontados pela política experimental de seu tempo, qual seja, a tendência republicana que, naquele período histórico da humanidade, orientava as novas formas de governo.

Redigido ainda sob as impressões marcantes dos últimos acontecimentos políticos do Brasil, este ensaio, mais do que simples contribuição para o esclarecimento de um fato, é um registro cruel da péssima impressão deixada pelo povo brasileiro no espírito do escritor. A leitura deste texto serve para reforçar a hipótese de que Ramalho não escreveu um livro sobre o Brasil porque se veria obrigado a produzir uma obra falsa se não quisesse magoar ainda mais as pessoas que the haviam dado as maiores provas de consideração e carinho e das quais havia recebido, por todos os lugares por onde andou, uma das melhores acolhidas de toda sua vida.

\footnotetext{
${ }^{238}$ Importante revista dirigida por Eça de Queirós que circulou em Portugal e no Brasil de julho de 1889 a maio de 1892, com um total de 24 números. Contou com a colaboração dos mais destacados escritores portugueses e brasileiros da época.
} 
De natureza sociológica, este ensaio está dividido em quatro partes: uma pequena introdução seguida de três capítulos apenas numerados com algarismos romanos.

Nesta pequena introdução, o ensaísta considerando-se "por muitos vínculos espirituais ligados à família brasileira"239, alude a um estudo dos destinos políticos do Brasil, publicado por Eduardo Prado na mesma Revista de Portugal e, conquanto reconheça a admirável lucidez crítica do amigo brasileiro, acredita que seu depoimento, de alguma maneira, poderia também ajudar a compreender a revolução política ocorrida no Brasil dois anos após a sua passagem pelo país.

Faz questão, no entanto, de tornar manifesto, ao fim desta introdução, que seu trabalho nada mais seria que "o simples testemunho de um viajante, estranho a toda espécie de solidariedade partidária"240.

Seguramente pensava ao fazer esta afirmação no cunho marcadamente monarquista imprimido por Eduardo Prado aos seus textos publicados na revista de Eça de Queiros; uma intenção que não foi seguida assim tão à risca a ponto de não permitir entrever a benevolência com que tratou a república brasileira, principalmente quando se tem em conta o ideal monarquista que orientou a sua postura frente à república implantada em seu país. Os vinte anos que separavam um fato histórico de outro foram suficientes para Ramalho reestruturar sua ideologia e reformular seus pontos de vista.

Após esta curta introdução, Ramalho principia o primeiro capítulo examinando e comentando as conseqüências do regime servil na constituição da sociedade brasileira. Para ele o servilismo era o principal responsável pelas deformações sofridas pelo povo brasileiro, provocando alterações sociais que, resumidamente, assim enumerou: "abastardamento do trabalho, constituição da ociosidade organizada, decomposição da disciplina, desonra do respeito"241.

Procura, através de exemplos colhidos no dia-a-dia, justificar seus pontos de vista: era o caso do condutor de bonde que considerava obrigação

\footnotetext{
${ }^{239}$ Ramalho Ortigão, “O quadro social da revolução brasileira”, in Revista de Portugal, p. 79.

240 Ibidem, p. 80.

${ }^{241}$ Ibidem, p. 90.
} 
coisa somente de escravo, do cocheiro que não admitia rapar o bigode, do garçom que não se sujeitava ao uso, obrigatório na Europa, do avental branco, de passageiros que por se recusarem à apresentação dos bilhetes de fiscalização obrigavam as companhias a adaptarem contadores mecânicos, além de outras pequenas coisas como, por exemplo, a inobservância e desrespeito aos anúncios proibindo fumar.

Apontava também como conseqüência do regime servil a dissolução do sentimento hierárquico, com grande permeabilidade entre as classes sociais, das quais distinguia com nitidez apenas duas: escravos de um lado e homens livres de outro. Porém, entre estes últimos, via com profundo desgosto e sutil maledicência "de cima a baixo, em toda a ordem social, promiscuidade completa, confusão absoluta"242.

Cita axiomas sociológicos, fala em "morbo servil", supõe um "vírus negro" a se alastrar e corromper a sociedade, sem, contudo, especificar o processo de alastramento e as formas de corrupção. Como justificativa compara a ópera de São Petersburgo, onde há na platéia lugares distintos para cada classe social, com a ópera do Rio de Janeiro em que nenhuma formalidade, neste sentido, era observada. Lembra também o que ocorria nas estradas de ferro brasileiras, onde não viu respeitada a classificação dos vagões - rigorosamente observada nos trens europeus - prejudicando os passageiros da primeira classe pela invasão dos que tiraram bilhetes para as classes populares.

No entanto, esta dissolução do princípio hierárquico, tida por Ramalho como conseqüência do regime escravocrata, é apontada por Sérgio Buarque de Holanda, em Raízes do Brasil ${ }^{243}$, como sendo um traço próprio da personalidade dos povos ibéricos, cuja nobreza jamais se encastelou como em outros países europeus e em lugar do privilégio, exaltou o prestígio pessoal, valorizando, mais que casta e linhagem, o êxito e o mérito de cada um.

\footnotetext{
${ }^{242}$ Ibidem, p. 85.

${ }^{243}$ Antônio Cândido, Teresina, etc, p. 142.
} 
Observação semelhante faz Costa Porto no capítulo intitulado "A hipertrofia da casa grande", no livro que escreveu sobre Pinheiro Machado, o influente político dos princípios da república brasileira.

Em Portugal, os pruridos de sangue não contavam: sobrelevavam, sim, o valor, a bravura e mesmo o dinheiro, este figurando freqüentemente como elemento de classificação, arrombando muitas portas e provocando a aproximação entre os possuidores de vastos patacões e a nobreza, rica em pergaminhos e brazões, mas mendiga de ouro e cruzados. ${ }^{244}$

E Costa Porto conclui afirmando que esta tradição foi transportada para o Brasil, "cuja história está cheia destas indistinções de fronteiras de classes" $^{245}$.

Não reconhecendo em seu próprio país a origem da permeabilidade social brasileira, Ramalho Ortigão, na falta de uma explicação melhor para esta herança que, se a um conservador representava um defeito, a um progressista poderia representar um apuro social, viu nela, simplesmente, mais uma influência da escravidão negra.

De mais a mais, a escravidão no Brasil, tanto a do negro como a do índio, é uma herança portuguesa, reconhecida e justificada pelo próprio Ramalho como medida política cujo objetivo era "fundar o trabalho, organizar a propriedade, criar a riqueza", instituindo e fixando, assim, a "comunidade social por meio de processos análogos àqueles de que provieram todas as civilizações européias" ${ }^{246}$, como se lê em seu discurso de 1887, proferido na inauguração do Gabinete Português de Leitura. E, no entanto, dois anos depois, ao se ler "O quadro social da revolução brasileira", tem-se a impressão de que o crítico português pôs de parte ou esqueceu o passado histórico de seu próprio país, atribuindo ao Brasil e a seu povo todo o mal que trazia em seu bojo a nefanda instituição. Pode ser que as opiniões proferidas no discurso estivessem sujeitas ao contexto em que se deram.

\footnotetext{
${ }^{244}$ Costa Porto, Pinheiro Machado e seu tempo, p. 13.

245 Ibidem, p. 13.

${ }^{246}$ Gazeta de Notícias, 11 de setembro de 1887.
} 
Que o regime escravocrata marcou profundamente a sociedade brasileira, assim como marcaria qualquer outra sociedade que a tivesse adotado como principal forma de organização do trabalho, não se discute.

Tendo à frente os povos da península Ibérica, a escravidão moderna, em muitos aspectos, diferente da escravidão antiga, veio no bojo da expansão marítima, praticamente redescoberta com os novos caminhos. Baseada na injustiça e no privilégio, contrariando padrões morais há muito estabelecidos ao conceder a uns direitos excluídos a outros, natural seria que influenciasse, em termos de dissolução dos costumes, aqueles povos. Caio Prado Júnior, por exemplo, diz ter sido ela um dos principais fatores do naufrágio daquela civilização, naufrágio do qual, diga-se de passagem, não escapou nenhuma das duas nações. "Foram elas que mais se engajaram naquele caminho; serão elas também suas principais vítimas"247.

E se a Inglaterra, que teve atuação relevante no restabelecimento e instituição da moderna escravidão, não sofreu tanto sua influência quanto os povos peninsulares foi porque o seu papel nesta história ficou praticamente restrito ao de nação intermediária. Para ela e seus comerciantes o negro não passava de simples mercadoria a ser comprada, transportada e vendida. $\mathrm{Na}$ Inglaterra o trabalho servil, propriamente, não teve lugar.

"O quadro social da revolução brasileira" foi escrito em dezembro de 1889 , e se o curto prazo entre o fato e sua interpretação pode ter levado Ramalho a apreciações equivocadas como esta, não lhe daria, no entanto, o direito de cometer injustiças, como o que se deu com o movimento abolicionista, que se achava em plena efervescência e praticamente incontrolável quando ele, em agosto de 1887, aportou no Rio de Janeiro. Contava com o apoio de, praticamente, toda a sociedade civil e foi deste ano o duro golpe dado pelos militares aos escravocratas com o pedido de dispensa da obrigação de perseguir negros fugidos. Havia recebido a adesão de lideranças políticas importantes como a do senador pernambucano João Alfredo, que mais tarde encaminhou e aprovou a Lei Áurea, e a de Antônio Prado, conselheiro da monarquia e um dos principais representantes da política

\footnotetext{
${ }^{247}$ Caio Prado Júnior, Formação do Brasil contemporâneo, p. 269.
} 
paulistana, além daqueles primeiros abolicionistas, dos quais o povo já havia arrebatado o comando do movimento. Isto ainda sem contar com a anuência da princesa Isabel, que desde 30 de junho deste mesmo ano regia o império, em substituição ao pai, pela Europa em tratamento de saúde.

Por esta época numerosos pasquins, quase sempre de curta duração e clandestinos, saíam a público e os seus editores eram, muitas vezes, médicos, farmacêuticos, advogados ou padres, que se faziam portavozes da raça negra. Nas cidades, as mulheres aderiam ao movimento, promovendo conferências, criando associações, organizando quermesses, angariando fundos que se destinavam à emancipação de escravos. A grande agitação radicalizou o discurso: a abolição representava uma causa nobre pela qual era belo e legítimo lutar, enquanto a escravidão uma coisa vergonhosa e indigna de ser defendida.

Se para alguns mais espertos ele deu público e eleitorado, não passando de expedientes pessoais, para muitos idealistas convictos representou um verdadeiro sentido de vida. No entanto, Ramalho só vê entre eles oportunistas de toda a espécie: "médicos sem doentes, advogados sem causas, jornalistas sem leitores, oradores sem ouvintes"248, tendo o movimento se convertido em agitação política com fim exclusivo de obter publicidade gratuita.

A raça negra, após três séculos de sofrimento no eito, "roçando o mato, plantando o café e a cana"249, havia se tornado presa da câmara e dos prelos, com direito a panfletos, pasquins, comícios em praças públicas e discursos em teatros. "Depois de explorado pelos fazendeiros, o negro passou a ser explorado pelos políticos" ${ }^{250}$, dizia sem constrangimento ou comiseração.

Além de infundada, nada havia de original nestas formulações, correntes na época. De semelhante acusação não ficaram livres nem mesmo alguns de seus principais expoentes, entre eles Joaquim Nabuco.

\footnotetext{
${ }^{248}$ Ramalho Ortigão, "O quadro social da revolução brasileira", in Revista de Portugal, p. 87.

${ }^{249}$ Ibidem, p. 88.

${ }^{250}$ Ibidem, pp. 87, 88.
} 
Muita retórica e desconsideração com os heróis anônimos que promoveram fugas, improvisaram esconderijos, auxiliaram a locomoção e o translado de cativos; desconhecimento e injustiça com espíritos abnegados, como, por exemplo, o de André Rebouças que nada regateou ao movimento, pondo à sua disposição muito de seu tempo e um pouco de suas posses.

É bem possível e muito provável que Ramalho Ortigão estivesse vendo o problema com os olhos do irmão, Joaquim, que temia um colapso na economia do país com o fim do trabalho servil ${ }^{251}$.

Finalizando este primeiro capítulo, Ramalho, a título de esclarecer o que considerava o parasitismo social entre os brasileiros, faz sentar à mesa de um fazendeiro das imediações da corte mais de cinqüenta comensais. Se não houvesse tanto exagero e nem se revelasse tão caricata a descrição que fez do senhor e sua clientela, ela até poderia servir para dar uma idéia do que foi o patriarcado rural no Brasil. Joaquim Nabuco em "Massangana", belo capítulo de Minha Formação, alude a este pequeno feudo escravocrata, praticamente fechado a ingerências externas, formado pelos cativos distribuídos pela senzala e a casa grande ao lado dos rendeiros que se ligavam "ao proprietário pelo benefício da casa de barro que os agasalhava ou da pequena cultura que ele lhes consentia em suas terras" ${ }^{252}$.

Ordinariamente, esta casta de rendeiros ou agregados era composta de indivíduos que, à custa de pequenos favores, justificavam o expediente de se abrigar à sombra larga do patriarca, dele recebendo auxílio e proteção.

A antipatia e o altivo desprezo com que notoriamente Ramalho trata esta realidade social brasileira principia pela vulgarização do título nobiliárquico do fazendeiro, a quem ele dá o tratamento desdenhoso de "sinhô" e segue pela curiosa relação das figuras marotas que compunham seu clã: 0 capanga façanhudo, o arrieiro anedótico, o caipira malicioso, o capadócio sentimental, o bacharel casadoiro e aspirante a deputado, além de outros mais.

\footnotetext{
${ }^{251}$ Influenciado por colegas congressistas que piamente acreditavam nisso, Joaquim da Costa Ramalho Ortigão, quando ocupou a presidência do Congresso de Lavradores, revelou-se francamente escravocrata, em artigos publicados pela imprensa conservadora.

${ }^{252}$ Joaquim Nabuco, Minha formação, p. 211.
} 
E é sem nenhum critério culinário que justificasse a miscelânea de pratos que coloca lado a lado sobre a mesa de um fazendeiro da província vejam bem - do Rio de Janeiro: moquecas, feijoadas, angus e vatapás.

Além do capadócio sentimental, que Ramalho considera uma variante do mandrião lazarone napolitano, nenhum outro elemento do rol elencado por ele seria enquadrado no conceito de parasitismo que, ao menos hoje, os dicionários registram: nem o capanga, nem o caipira, nem o arrieiro ou outro qualquer, que todos eles tinham, sim, o seu lugar e a sua função no seio daquela sociedade.

E o que dizer do fazendeiro, daquele "sinhô" autoritário, poderoso e rico que se aristocratizava, enquanto na varanda da casa-grande, dormindo, digeria o almoço em cadeira de balanço. Seria ele o parasita?

Como já se disse, se a descrição não fosse tão caricata, teria ainda hoje algum valor documental. No artigo com que rebate a crítica de Ramalho, Pardal Mallet - que já havia dito não ter ele vindo com o espírito preparado para bem compreender o Brasil - ironiza, dizendo que os comensais agrupados pela fantasia do escritor dariam um "belo começo de romance faceto" 253 .

O segundo capítulo de "O quadro social da revolução brasileira" principia por comentários à instrução, que Ramalho considera apenas um dos aspectos da educação pública e não o mais importante. E não é sem razão quando se pensa nela como forma de transmissão de conhecimentos visando $o$ desenvolvimento intelectual do indivíduo para o exercício de uma atividade profissional qualquer, enquanto a educação, de complexidade maior, é toda uma ação exercida de geração a geração, visando a preparação do homem para o exercício pleno da cidadania. E nesse sentido nenhuma instituição estava mais bem preparada que a Companhia de Jesus, acreditava ele, para este desenvolvimento e esta preparação.

O jesuíta, por meio de um complexo e integral sistema pedagógico, abrangendo a educação intelectual, a educação moral e a

\footnotetext{
${ }^{253}$ Gazeta de Notícias, 8 de março de 1890.
} 
educação física, preparava completamente o mais perfeito homem para a concorrência no conflito social em que era destinado a intervir. $^{254}$

Em sua opinião, do que mais se ressentia a instrução pública brasileira era da disciplina escolar, prejudicada pelo que chamou de "liberalismo empírico da administração moderna" ${ }^{255}$, agente responsável pela abolição, tanto nas escolas brasileiras quanto portuguesas, da disciplina eclesiástica, verdadeiro instrumento que na mão do jesuíta impunha à mocidade o sentimento do dever e da solidariedade, o espírito de sacrifício e de regularidade, firmando o caráter para as dificuldades da vida. "Só assim se formam cidadãos, o que é uma coisa diferente de formar bacharéis"256.

De maneira geral, teve uma justa compreensão da instrução pública brasileira. Com clareza de vista apontou sua grande deficiência e vulnerabilidade, seu verdadeiro calcanhar de Aquiles: o descaso com que sempre foi tratada a instrução elementar, tão insuficiente nos tempos do império que dos sete anos de instrução secundária, o primeiro deles tinha por fim, unicamente, suprir a deficiência da primeira instrução, do ensino primário, que Ramalho considerava "a base verdadeira do progresso para a mentalidade de um povo" 257 , comungando assim com o pensamento de uma série de educadores antigos e modernos.

Aprovou, com ressalvas o ensino secundário e plenamente 0 superior, dando especial destaque para a Escola de Medicina, "um instituto comparável aos mais perfeitos da Europa"258. Considerou bem aparelhados os laboratórios e bem administrados os museus, as bibliotecas e os arquivos.

Vale ressalvar que em matéria de educação pública o que não lhe agradava no Brasil tampouco Ihe agradava em Portugal, considerando, por sua vez, a Argentina - visitada na ocasião - muito mais avançada que qualquer daqueles dois países no que diz respeito à organização do ensino primário ou

\footnotetext{
${ }^{254}$ Ramalho Ortigão, “O quadro social da revolução brasileira”, in Revista de Portugal, pp. 91, 92.

${ }^{255}$ Ibidem, p. 91.

${ }^{256}$ Ibidem, p. 91.

${ }^{257}$ Ibidem, p. 93.

${ }^{258}$ Ibidem, p. 91.
} 
elementar, tendo em boa conta e reputando muito mais convincente e adequado o aspecto disciplinar nas escolas daquele país.

Depois das observações sobre o ensino, segue um tópico sobre a imprensa brasileira. $\mathrm{O}$ rol de jornalistas $\operatorname{citados}^{259}$ demonstra familiaridade, ao menos com os nomes dos mais destacados profissionais da imprensa no Brasil do último quartel do século XIX.

Salienta a sagacidade crítica e o poder de raciocínio de uns, a delicadeza artística e a vasta cultura de outros, sem deixar, no entanto, de condenar o espírito mercantilista de empresas ocupadas unicamente em publicidade e que exploravam a "pequena intriga local, as rivalidades de classe, as paixões burguesas, as malquerenças pessoais" ${ }^{260}$, em detrimento de assuntos outros, políticos, artísticos ou sociais, de mais peso e interesse intelectual.

Era o "mexeriquismo" das seções dos "Apedidos" e das mofinas jornalísticas que, a seu entendimento, asfixiavam o "interesse da controvérsia filosófica"261. Até pode ser que ele tivesse razão e ocorresse isto mesmo com as matérias de fundo dos periódicos da época, durante os três meses em que esteve no Brasil; mas com certeza nem sempre foi assim. Lembre-se, por exemplo, o que de deu pouco tempo antes com aquelas figuras que Martinho de Campos alcunhou de "os ingleses do Dantas", e que outros não eram senão Joaquim Nabuco, Rui Barbosa, Rodolfo Dantas e Gusmão Lobo, que sob pseudônimos ingleses defenderam na seção dos "Apedidos" do Jornal do Comércio o projeto de abolição do gabinete liderado pelo senador baiano.

Carolina Nabuco, na obra que escreveu sobre o pai, conta um pouco do que foi esta coluna na conservadora folha fluminense.

$$
\text { É preciso lembrar que os “Apedidos" do Jornal do }
$$

Comércio foram uma tradição. Ninguém pensava em não os ler. A vida do Rio de Janeiro fervilhou longos anos nessas colunas pagas.

\footnotetext{
${ }^{259}$ Eis alguns dos nomes por ele citados: Machado de Assis, Ferreira de Araújo, Sílvio Romero, Taunay, José do Patrocínio, Joaquim Nabuco, José Carlos Rodrigues, Rui Barbosa, José Veríssimo, Quintino Bocaiúva, Benjamim Constant, entre outros.

${ }^{260}$ Ramalho Ortigão, "O quadro social da revolução brasileira", in Revista de Portugal, p. 93.

${ }^{261}$ Ibidem, p. 93.
} 
Era a tribuna onde os interessados vinham deslindar as questões do dia, públicas ou íntimas. As justificações pessoais, os cumprimentos banais, a desprezível "mofina", alternavam-se com as manifestações políticas de toda espécie. ${ }^{262}$

Sendo assim, não se pode negar a possibilidade aparente de Ramalho Ortigão ter deduzido e transformado em regra geral um fenômeno passageiro que deveria ser tratado em seu aspecto particular.

\section{5 - O Brasil visto por Ramalho}

Elegante, desempenado e totalmente influenciável pela marcialidade pomposa e seu aparato cênico, não surpreende a decepção de Ramalho ao visitar o palácio imperial e ser recebido unicamente por um velho criado em jaquetão de alpaca, que registrava os nomes em seu caderninho de anotações molhando na língua a ponta o lápis. E não podia ser mais triste e desoladora a descrição das dependências interiores do palácio de São Cristóvão.

Ao cimo da escada, desguarnecida de todo o ornato, sem tapete, sem flores, sem esculturas, atravessava-se um salão deserto, unicamente guarnecido ao longo dos muros por alguns tremós em mogno do tempo do império napoleônico; tomava-se no fundo à esquerda; percorria-se uma das quatro galerias de um triste claustro de convento pobre, ao centro de cujo pátio mesquinhamente ajardinado chapinhava monótona a água de um repuxo; e penetrava-se finalmente na antecâmara de um salão pintado a fresco no tempo de D. João VI, e guarnecida da mais banal e mais incaracterística mobília de mogno moderno. $^{263}$

Com seu estilo predominantemente pictórico, caracteriza a triste e comedida sobriedade do ambiente através de adjetivos, verbos e advérbio,

\footnotetext{
${ }^{262}$ Carolina Nabuco, A vida de Joaquim Nabuco, p. 151.

${ }^{263}$ Ramalho Ortigão, op. cit., p. 96.
} 
sendo toda melancolia de que se impregnou simplesmente resumida nestes termos: "triste claustro de convento pobre". Em outros casos, o que se destaca é o aspecto burlesco, como acontece, por exemplo, com a descrição da solenidade do dia 2 de janeiro, ocasião em que D. Pedro II pomposamente desfilava pelas ruas do Rio em uma traquitana dos tempos de seu avô, de cetro e coroa, vestido de cetim, com um "manto transparente guarnecido de penas de tucano"264, que o sarcasmo do autor faz lembrar um desfile de escola de samba, dos dias atuais.

Muito embora desacreditasse a corte e seu império, reconhecia qualidades no imperador: justo, generoso, compadecido e terno, ao lado de alguns defeitos considerados graves quando se quer um rei influente $e$ dominador: era recluso, inestético e especulativo.

Ramalho teria gostado de ver uma corte mais viva e luxuosa, ao lado de uma aristocracia mais atuante, alegre e vistosa, para que juntos funcionassem, espelhando, a civilidade da polidez e da cortesia, dos bons costumes e da perfeita compreensão da idéia de conforto e elegância, servindo assim de fonte e inspiração para o povo. Mas, contrariando toda expectativa, o que viu e considerou foi que a "influência da corte nos usos, nos costumes, no gosto do público, sempre que não era nula, era prejudicial”265.

Espírito desenvolvido no hábito da leitura e na convivência com intelectuais, com senso de justiça, inegável honestidade de propósitos e propalada modéstia, despachando, no paço, mais como um burocrata de carreira que um soberano imperador, era público e notório o desapego de D. Pedro II às pompas e homenagens.

Gilberto Freire, em $A$ propósito de Dom Pedro II, conferência pronunciada na Biblioteca do Estado de Pernambuco, em 1925, no centenário de nascimento do imperador, destacou semelhante aspecto de sua vida e também de sua corte. Para o sociólogo pernambucano, que contava por esta

\footnotetext{
${ }^{264}$ Ibidem, p. 98.

265 Ibidem, p. 95.
} 
época com vinte e cinco anos e ainda não havia publicado seu grande livro, faltou a ela um certo "brilliant setting of $\sin ^{\text {"266. }}$.

E assim sendo, do que sentiu falta Ramalho Ortigão em 1887, sentiu falta Gilberto Freire em 1925: uma corte exuberante, rica de mundanismo, pompa e suficientemente capaz de seduzir e provocar a imaginação burguesa. Mas como o sociólogo brasileiro foi sempre um grande leitor do crítico português, não se pode descartar a possibilidade de the ter sido esta idéia sugerida pela leitura de "O quadro social da revolução brasileira", o ensaio que embora não seja citado em sua conferência, sabe-se que era de seu conhecimento pelas citações de pequenas passagens, facilmente identificáveis.

Além de recluso e especulativo, não via Ramalho na pessoa do imperador, velho e adoentado ${ }^{267}$, um chefe de governo capaz de impor aos conservadores uma série de medidas e reformas de que tanto o país carecia e ele assim enumerava: remodelação da propriedade agrícola, reforma da educação, descentralização federativa, naturalização dos estrangeiros, sendo que esta última, aparentemente simples, desdobrava-se em outras medidas, exigindo "registro civil, secularização dos cemitérios, liberdade de cultos, separação da igreja e do estado" 268 , entre outras.

A remodelação da propriedade agrícola, priorizando as pequenas e médias propriedades e a diversidade de cultura, era um tema constante das conversas de Joaquim Nabuco, enquanto a descentralização federativa era o carro-chefe das campanhas de Rui Barbosa, sendo voz corrente na política que se ela conferisse mais autonomia e poder aos estados poderia acalmar e dar sossego a muitos espíritos separatistas. Ramalho Ortigão que esteve em São Paulo e conheceu alguns deles era dessa mesma opinião.

Acontece que para encarar os liberais-conservadores, os conservadores empedernidos e enfrentar as dificuldades daquelas reformas, $\mathrm{o}$

\footnotetext{
${ }^{266}$ Gilberto Freire, Perfil de Euclides da Cunha e outros perfis, p. 128.

${ }^{267}$ O conhecimento de Ramalho Ortigão sobre D. Pedro II foi de leituras ou por ouvir dizer, pois quando esteve no Brasil o imperador encontrava-se na Europa em tratamento de saúde. No entanto, ao ler o ensaio, sem esta lembrança, julgamos tratar-se de coisa vista, tal é o grau de sugestão estilística e a capacidade de convencimento do autor.

${ }^{268}$ Ramalho Ortigão, "O quadro social da revolução brasileira”, in Revista de Portugal, p. 100.
} 
ideal e mais indicado seria um temperamento de moço, mesmo que em um corpo de velho. Só um rei moço - se não no físico ao menos no temperamento - poderia talvez ainda representar para o Brasil "um penhor de ordem, uma influência de civilização, um agente de progresso"269.

Pode ser que se encontre neste ideal desejado a explicação para um diálogo entre Ferreira de Araújo e Luís Couty ${ }^{270}$, registrada por Ramalho Ortigão. Ao ser interrogado pelo médico francês, sobre qual "homem de bem" teria condições de equacionar e resolver os problemas que afligiam a sociedade brasileira, Ferreira de Araújo Ihe teria respondido: "- Não é já de um 'homem de bem' que o Brasil precisa, é de um 'homem' "271.

Ramalho entendeu que Ferreira de Araújo aludia à falta de iniciativa do velho imperador. Era justa a interpretação, mas não era a única e este "homem" em destaque talvez não fosse outro senão o príncipe real que todos gostariam de ter em lugar da princesa herdeira, um homem novo e arrojado, com autoridade, prestígio e disposição para suceder ao pai no trono e, sem esmorecimento, enfrentar as dificuldades e levar a bom termo as reformas indispensáveis à modernização do país.

Rocha Pombo, na alentada história que escreveu sobre o Brasil, arrolou, entre as conhecidas causas que provocaram a queda da monarquia, uma pouco citada por outros historiadores e que ora será lembrada por se ajustar perfeitamente àquela interpretação. Para ele, junto às outras conhecidas causas, figuraria também "a falta de um príncipe real, que se fizesse popular e simpático aos brasileiros, para suceder”272 o imperador doente e já sem grande interesse pelo comando.

Eça de Queirós, comentando a proclamação da república brasileira - a seu modo de ver mais uma transformação que propriamente uma revolução - em uma seção da Revista de Portugal, intitulada "Nota do mês",

\footnotetext{
${ }^{269}$ Ibidem, p. 95.

${ }^{270}$ Luís Couty, médico francês falecido no Rio de Janeiro em 1881. Professor de Biologia Industrial da Escola Politécnica, editor da Revue de France et du Brésil, autor de A escravidão no Brasil, e, segundo Ramalho, quem "mais lucidamente expôs a equação do destino brasileiro". (Ramalho Ortigão, "O quadro social da revolução brasileira", p. 100)

${ }^{271}$ Ramalho Ortigão, op.cit., p.100.

${ }^{272}$ Rocha Pombo, História do Brasil V, “A república”, p. 307.
} 
firmada por ele com o pseudônimo de João Gomes, lembra que "o reinado da princesa dona Maria ${ }^{273}$ e do conde d'Eu, ninguém o queria - nem mesmo talvez o imperador, no fundo do seu espírito, por motivos de ordem filosófica"274.

Todas estas formulações, conceitos e idéias acabam picando nosso espírito, fazendo brotar, à toa e sem porquê, uma instigante, porém incômoda pergunta: - Qual teria sido a história da monarquia no Brasil, caso não se houvesse cumprido, também neste país, o destino trágico dos primogênitos da Casa de Bragança? Eis aí que se apresenta um tema a mais para a fantasia e o devaneio dos ficcionistas.

Pondo um fim aos comentários deste segundo capítulo, vale ainda a pena falar da decepção de Ramalho com a realidade social da cidade do Rio do Janeiro. As condições urbanas de insalubridade e falta de higiene que diz ter encontrado naquela cidade eram em sua opinião um sério obstáculo ao desenvolvimento da corrente migratória oriunda da Europa.

O descaso com que viu tratada a educação física no Brasil - onde conheceu pouquíssimas sociedades esportivas - só poderia decepcioná-lo, a ele que tinha os exercícios físicos em grande conta e granjeara na juventude respeito como esgrimista destro e habilidoso, causando, por isso mesmo, surpresa entre aqueles que o conheciam mais de perto o desfecho daquele duelo travado no Arco da Água com Antero de Quental.

A ele que era adepto de longas caminhadas, pareceu mau o costume, comum entre os brasileiros, de utilizar o bonde até mesmo para cobrir as menores distâncias, sentindo falta de calçadas largas e avenidas longas, onde pudesse levantar a cabeça, estufar o peito e caminhar com disposição e vontade.

E a propósito, observou o andar dos homens do Rio de Janeiro e não deixou de comentar:

\footnotetext{
${ }^{273}$ É um equívoco de Eça de Queirós: o nome completo da princesa era Isabel Cristina Leopoldina Augusta Micaela Gabriela Rafaela Gonzaga.

${ }^{274}$ João Gomes, Revista de Portugal, v. I, p. 781.
} 
Ninguém trilha o solo sob o vigor de passadas regulares e firmes. Caminham todos sinuosamente, sem perpendicularidade e sem força, como quem vai convalescente e debilitado, com os pés doloridos, por um terreno sinuoso. ${ }^{275}$

Ao que parece, cabe aqui outra pergunta: - Não seria isto a ginga carioca, aquele jeito próprio de caminhar que a Ramalho pareceu um defeito de constituição física daqueles homens?

Foi mais além e, sem temor algum, insinuou que a falta de exercícios físicos era a responsável pelos ombros estreitos, os pulsos finos, as mãos esguias e frágeis da maioria dos brasileiros, uma insinuação suscetível de melindres e retaliações e que obviamente ninguém lhe abonaria.

Como era de se esperar, o terceiro e último capítulo do ensaio pouco maior que a curta introdução - é o capítulo das conclusões. Evocando o que havia sumariado nos capítulos anteriores a respeito do quadro político e social brasileiro, anterior ao advento da república, Ramalho considera fácil a explicação para o "golpe de estado do dia 15 de novembro e os acontecimentos que se lhe seguiram"276. Estando já previsto e anunciado há algum tempo, não teve, em sua opinião, caráter político ou filosófico, mas puramente econômico. Para ele, mais que tudo, o que fez perder a monarquia foi a abolição dos escravos, um verdadeiro golpe na economia do estado com o conseqüente enfraquecimento da aristocracia rural, a classe responsável pela sustentação do regime.

A revolução brasileira fez-se de direito e de fato no dia em que pela abolição da escravatura cessou de existir o feudalismo territorial, constituído pela propriedade dos grandes fazendeiros senhores de negros, e base da única aristocracia poderosa e conservadora do império. ${ }^{277}$

Não há novidade alguma nesta observação, uma vez que relacionar a queda da monarquia com a abolição da escravatura foi um

\footnotetext{
${ }^{275}$ Ramalho Ortigão, "O quadro social da revolução brasileira", in Revista de Portugal, p. 95.

${ }^{276}$ Ibidem, p. 100.

${ }^{277}$ Ibidem, pp. 100, 101.
} 
procedimento comum na época. A célebre advertência feita, logo após a assinatura da Lei Áurea, pelo barão de Cotegipe à princesa Isabel, que, vaidosa por ter vencido, queria saber da aposta entre eles estabelecida, sintetiza brilhantemente esta maneira de pensar dos homens do tempo: Ganhas a aposta, mas perdes a coroa.

E perderia a coroa, a seu modo de ver, porque o regime monárquico se veria desamparado pela aristocracia rural cujo patrimônio podia ser calculado pelo número de escravos. Seria isto assim como uma espécie de desabafo de insatisfeitos (desforra de magoados) dirigido à coroa. Ramalho, no entanto, não via a questão sob um prisma moral por excelência; para ele a libertação dos escravos teve um significado mais profundo pelo abalo que causou na estrutura econômica da classe que alicerçava o poder. Não era simplesmente uma questão moral, mas uma intrincada questão econômica. E aí ele observou bem, pois a economia do Segundo Império, baseada na monocultura, no latifúndio e na escravidão, dependia fundamentalmente do braço escravo para assegurar a sua subsistência e, quando veio a abolição, a aristocracia rural, que garantia as finanças do estado e sequer podia ouvir falar na libertação dos negros, ainda não se achava suficientemente pronta para a utilização do braço assalariado em sua lavoura. Isto em tempos de implementos agrícolas rudimentares representava um verdadeiro desastre.

Daí que o enfraquecimento econômico desta aristocracia enfraqueceu também o trono que tinha nela a sua principal base de sustentação. Ramalho acreditava que todo sistema representativo sobre o qual se apoiava o poder monárquico dependia, para sua sustentação, de uma elite suficientemente forte para atuar ao lado do soberano e juntos constituírem uma força capaz de impor e manter, até mesmo coercitivamente se fosse o caso, a ordem e o respeito às normas estabelecidas. Com a receita pública achatada e o poder político diminuído a monarquia não resistiu e a sua queda no Brasil não foi surpresa alguma para Ramalho que via a proclamação da república de 15 de novembro como o natural desenvolvimento de um processo político rigorosamente lógico.

Até por volta de 1920, esta hipótese de Ramalho jamais foi levada em consideração. Os historiadores ou políticos que trataram do assunto, até 
esta década, consideraram a república o fruto de ressentimentos acumulados pelo clero, pelos militares e, principalmente, pelos fazendeiros senhores de escravos. Emília Viotti da Costa diz que só a partir daí é que "alguns historiadores começaram a se interessar pelos aspectos econômicos e sociais da história e formularam novas hipóteses"278 a respeito da queda do trono. Em 1922, estudando as relações entre abolição e república, Licínio Cardoso publicou em uma obra coletiva um trabalho pioneiro que colocava em novas bases o problema das relações entre elas: "Afirmava ele que a abolição, atingindo a aristocracia rural, suporte da monarquia, destruíra-lhe as bases"279. Isto é, praticamente, a mesma coisa que Ramalho Ortigão já havia dito em seu ensaio de1889.

Não foram os barões do café e os senhores de engenho que, ressentidos por causa da abolição, desampararam o trono, porém e muito pelo contrário, o trono é que, com a libertação dos negros, desamparou os barões do café e os senhores de engenho.

Eis aí em linhas gerais o que é "O quadro social da revolução brasileira", este ensaio publicado, primeiro na Revista de Portugal e em seguida na Gazeta de Notícias. Superficial e pretensioso, como o próprio título revelava, nestas poucas páginas de pura má vontade, se achava resumido o tão ansiosamente esperado livro de Ramalho Ortigão sobre o Brasil. Obviamente que o resultado final de toda a expectativa não poderia ser mais decepcionante. Pretender explicar a revolução republicana no Brasil por meio de observações pessoais de fatos corriqueiros, colhidos no dia a dia, foi seguramente seu principal defeito; principalmente quando se leva em conta o que assegura Pardal Mallet a respeito destas observações pessoais: "não se conformam inteiramente com a realidade dos fatos, e fazem desconfiar que 0 Ramalho artista e sonhador inventa sempre um bocadinho dos episódios que

\footnotetext{
${ }^{278}$ Emília Viotti da Costa, Da monarquia à república, p. 416

${ }^{279}$ Ibidem, p. 419.
} 
Ihe sucedem em viagem"280. Mais ficção do que propriamente fidelidade ao observado em seus registros e apontamentos, que muitas vezes faz pensar em um caricaturista a surpreender aspectos inusitados, risíveis ou grotescos, das realidades observadas.

Mesmo antes de conhecer o Brasil, Ramalho já não escondia uma certa indisposição com o povo brasileiro, em geral, ressalvando apenas as pessoas de trato íntimo, o seleto grupo dos amigos mais chegados. Porém, a massa anônima, para sua educação européia, era de maneira geral intolerável. Certa vez, na correspondência familiar, sua intolerância se mostrou tanta que chegou ao ponto de dizer à esposa, após encontro com um grupo de viajantes brasileiros, tratar-se de uma "raça incivilizável, que deveria ser proibida de viajar sem diploma especial", somente conferido por um imaginário júri internacional, "a quem tivesse educação e instrução para isso"281.

Crianças bulhentas e adultos intempestivos, quando em momentos inoportunos, tornavam, em sua opinião, intolerável um grupo de brasileiros.

Embora seja mais transparente e carregado na correspondência familiar, não é somente aí que se revela sua má vontade em relação ao povo brasileiro. Vale aqui também lembrar que já nos primeiros números de $A s$ farpas, muitas vezes, o Brasil foi depreciativamente tratado como "o país da mandioca e do feijão preto" ${ }^{282}$.

Injustificável, infundado e preconceituoso, como os demais trabalhos sobre o país, "O quadro social da revolução brasileira" não ficou sem resposta, nem seu autor impune. Em abril de 1890, Eça de Queirós escrevia à esposa contando que Ramalho havia sido desancado sem misericórdia pela imprensa brasileira: "Asno e poseur são os nomes mais doces com que 0 esmagam"283.

Poseur foi como o tratou Pardal Mallet naquele texto da Gazeta de Notícias e também Lenita, a personagem do romance $A$ carne, de Júlio

\footnotetext{
${ }^{280}$ Gazeta de Notícias, 8 de março de 1890.

${ }^{281}$ Ramalho Ortigão, Cartas a Emília, p. 18.

${ }^{282}$ Idem, As farpas X, p. 15.

283 "Eça de Queirós entre os seus", in Arnaldo Faro, Eça e o Brasil, p. 198.
} 
Ribeiro. Bem pra perto do final da história do casal de amantes, ela que já havia deixado a fazenda e retornado para São Paulo escreve a Barbosa que lá havia permanecido uma carta, cuja data o livro registra: 5 de outubro de 1887 . É curioso notar que logo no dia seguinte a Gazeta de Notícias dava uma nota de primeira página falando da acolhida de Ramalho Ortigão pela imprensa paulista, o que permite deduzir que muito provavelmente Júlio Ribeiro se achava entre aqueles que acolheram o escritor.

Mas, voltando à carta, nela, em dado momento, Lenita diz de Ramalho qu'il pose toujours, apesar de homem de combate e grande escritor e, ainda, Ihe presta tributo com uma bela descrição, gravando bem a imagem que dele faz em sua passagem pelas ruas da capital da província paulista. Foi assim que a personagem de Júlio Ribeiro viu e descreveu este homem de cinqüenta e um anos de idade que, em fins do século dezenove, andava pelas ruas de São Paulo, acompanhado de Gaspar da Silva, diretor do Diário Mercantil, o importante jornal paulista que em sua edição de 4 de setembro já havia publicado na primeira página o seu retrato a bico de pena:

Era um sujeito corpulento, corado, limpo, no descambar da idade viril, ou melhor no verdor da velhice. $\mathrm{O}$ bigode farto, betado aqui e ali por um fio de prata, e as longas costeletas acentuavam-se com nitidez no rosto fresco, caprichosamente escanhoado. O cabelo curto dividia-se em pastinhas despretensiosas no alto da testa vasta, gravata branca de nó, colete fechado até o nó da gravata, fraque, flor enorme na lapela, calças de casimira preta com listinha de seda branca, chapéu preto, alto, mole, sapatos Clark, pince$n e z . . .{ }^{284}$

Lenita, em seu passeio pela cidade, deparou-se com Ramalho Ortigão na Casa Garraux, uma espécie de livraria e bazar de luxo, onde se podia encontrar de tudo "desde o livro raro até a pasta de açofeita, passando pelo Cliquot legítimo e pelos cofres à prova de fogo" ${ }^{285}$. Fingindo examinar uma estante de livros, conseguiu se aproximar, prestar atenção em sua pessoa e até mesmo ouvir-Ihe trechos da conversa.

\footnotetext{
${ }^{284}$ Júlio Ribeiro, A carne, pp. 152, 153.

${ }^{285}$ Ibidem, p. 152.
} 
Embora visse nele um "belo homem", Lenita fazia-lhe certas restrições e na carta chegava até a dizer que nem mesmo gostava dele, por considerá-lo "trabalhado, limado, castigado demais" ${ }^{286}$. Era a seu gosto muito afetado, alguém que estava sempre levando em conta o efeito de suas atitudes, de seus gestos e de suas palavras, sem deixar de criar oportunidades para falar de sua toilette, de dizer "que se banhou, que se barbeou, que mudou a roupa branca" ${ }^{287}$, em grande exagero de cuidados higiênicos e preocupações pessoais: "Afeta pelo asseio, pelo cuidado do corpo um culto que chega a se tornar impertinente"288.

Pardal Mallet, por seu turno, não deixava por menos e dizia que a vaidade e a presunção de Ramalho ao descrever o banho que havia tomado pela manhã era tanta que servia aos espíritos antilusitanos para espalhar o boato de que em Portugal "a ducha matutina é uma extravagância de artista e um luxo de pouca gente" 289 .

Para Mallet, até a publicação de "O quadro social da revolução brasileira", pela Gazeta de Notícias em 1890, "Ramalho era um ídolo" e as suas opiniões "sobre os homens e as coisas de seu tempo" assumiam no Brasil um caráter de verdadeiras sentenças inapeláveis, mesmo porque, normalmente os assuntos tratados, quando não estavam longínquos, eram poucos conhecidos. Porém, desta vez e com este ensaio outra era a figura e a situação apresentada, achando-se agora o leitor devidamente apto e em "condições de criticar o crítico, de conhecer-lhe os processos de análise, de superpor 0 subjetivo das opiniões no objetivo do assunto" ${ }^{290}$.

O leitor era como um bom burguês que vai ao teatro, e que no dia seguinte procura a crítica de seu jornal, porque não se deu ao trabalho nem tem o hábito de sistematizar as suas impressões próprias, e quer que lhas forneçam já prontas numa síntese logicamente bem formulada. ${ }^{291}$

\footnotetext{
${ }^{286}$ Ibidem, p. 153.

${ }^{287}$ Ibidem, p. 153.

${ }^{288}$ Ibidem, p. 153.

${ }^{289}$ Gazeta de Notícias, 6 de março de 1890.

${ }^{290}$ Ibidem.

${ }^{291}$ Ibidem.
} 
Acontece que ao findar a leitura do ensaio ele achou que a síntese não estava "logicamente bem formulada", que não era condizente com a realidade que ele tão bem conhecia, que era retórica, falsa, errada mesmo e, aí então, assaltou-Ihe uma "grande dúvida sobre o valor do critério que presidiu à obra crítica de seu ídolo de ontem"292. Ramalho Ortigão era um ídolo. "E mal dos ídolos no dia em que uma suspeita irreligiosa penetra no espírito dos crentes" $^{\prime 293}$. Desconfiado, saiu à rua a sondar a opinião geral e conheceu, então, que havia revolta, protesto e reivindicação de justiça.

Eça de Queirós esteve por duas vezes em sua vida prestes a conhecer o Brasil: a primeira seria aquele consulado na Bahia, trocado pelo de Cuba e a segunda, quimérica, seria a realização daquele sonho de Eduardo Prado - fazer dele o ministro português no Rio de Janeiro.

Em sua obra sobre o romancista, Arnaldo Faro pondera que talvez tenha sido melhor mesmo que eles não se tivessem conhecido pessoalmente, para que hoje não houvesse, quem sabe, "uma página desagradável a esquecer"294.

"Uma página desagradável a esquecer", quem sabe não seja tudo o que hoje o país tenha a fazer com aquele ensaio de Ramalho Ortigão.

\section{6 - A esquina dos séculos}

"O quadro social da revolução brasileira", como se sabe, foi publicado pela Gazeta de Notícias no início do último ano da década de 1880. Em comparação com esta, a década iniciada no ano seguinte apresentou uma redução significativa no volume de "Cartas Portuguesas" enviadas pelo escritor ao diário brasileiro. Para se fazer uma idéia desta redução, basta saber que a totalidade das colaborações publicadas pelo jornal na década de 1890 é ainda menor que a de um simples ano da década anterior. No ano de 1885 foram

\footnotetext{
${ }^{292}$ Ibidem.

293 Ibidem.

294 Arnaldo Faro, Eça e o Brasil, p. 253.
} 
publicadas 57 colaborações, contra 54 de toda esta década. Enquanto ainda não se souber o real o motivo desta redução, uma dúvida permanecerá no ar: teria sido ela conseqüência da má impressão causada pela publicação do ensaio?

Além disso, a grande maioria das colaborações desta nova década, a de noventa, foi publicada pela Gazeta de Notícias em seções com novos nomes: ou saíam em uma seção denominada "Jornal de um Lisboeta", ou saíam em uma outra, denominada "Impressões Portuguesas".

Há ainda a se levar em conta que este pequeno volume de colaborações ficou restrito à primeira metade dos anos noventa, já que de outubro de 1895 a setembro de 1901 matéria alguma aparece firmada por ele.

Durante todo o mês de dezembro do ano de 1900, a Gazeta de Notícias publicou, em forma de clichê, como era de seu costume ao fim de cada ano, o anúncio dos principais colaboradores e correspondentes para o ano seguinte. Entre outros, eram anunciados Machado de Assis, Olavo Bilac e Araripe Júnior como colaboradores e Max Nordau, Joaquim de Araújo e Jaime Batalha Reis como correspondentes, respectivamente, da Alemanha, da Itália e de Londres, aparecendo entre eles, porém, à parte e em destaque, como correspondente de Portugal, o nome de Ramalho Ortigão.

Este notável escritor, antigo colaborador da Gazeta já comunicou à empresa a sua resolução de continuar a honrar a Gazeta com a sua preciosa colaboração. ${ }^{295}$

Era ainda anunciada a retomada das "Cartas Portuguesas", que desde 1895 se achavam ausentes das páginas do jornal. Ocorre, porém, que, embora a Gazeta assegurasse a seus assinantes a volta do antigo colaborador e insistisse com os anúncios até princípios de 1901, a primeira destas propaladas cartas só veio mesmo a ser publicada em setembro deste ano.

Ainda não se sabe ao certo, porém uma razão há de existir para explicar a ausência das cartas neste semestre, pois que não seria irresponsavelmente que o jornal estamparia tantos anúncios. Que deve ter

\footnotetext{
${ }^{295}$ Gazeta de Notícias, 1 de dezembro de 1900.
} 
havido algum entendimento entre o escritor e o diário brasileiro para a retomada dos trabalhos não resta a menor dúvida. Passagens de três cartas comprovam o fato: a primeira delas foi enviada por Ramalho ao conde de Sabugosa, a segunda à filha, Berta, e a terceira ao genro, Antônio Ramos, com ela casado.

Para bem compreender o conteúdo da passagem da primeira delas é preciso saber o seguinte: quando o conde de Arnoso pensou em uma ajuda aos filhos e à viúva de Eça de Queirós, falecido em agosto de 1900, considerou que, além de uma pensão outorgada pelo governo português, valeria a pena tentar obter, para socorro imediato da família, algum recurso através de uma subscrição pública no Brasil. Daí que, imediatamente se lembrou de Ramalho Ortigão, antigo colaborador da Gazeta de Notícias, que ele considerava um nome suficientemente popular e com bastante autoridade para redigir um manifesto e lançar a idéia na imprensa brasileira. Posto a par do projeto, Ramalho prontamente se propõe a colaborar ${ }^{296}$, revelando em carta enviada de Florença ao conde de Sabugosa, outro dos "Vencidos da Vida", seu entusiasmo e também seu empenho: "Daqui mesmo, provavelmente, lançarei a idéia da subscrição na Gazeta de Notícias, para onde recomeço a escrever"297.

Ao final da segunda carta, enviada de Veneza a sua filha Berta em 24 de agosto de 1900, Ramalho, alegando falta de tempo para não escrever ao genro, justifica-se, mas não esquece as recomendações: "Dá-lhe um grande abraço da minha parte e dize-lhe que pode mandar dizer que sim à Gazeta de Notícias". Da asserção final se pode concluir que se era ele quem daria a resposta, muito provavelmente teria sido ele também o portador da proposta do jornal para a retomada dos trabalhos. Após o recado ao marido,

\footnotetext{
296 Mostrando-se interessadíssimo na causa, por todos considerada justa e oportuna, Ramalho chega a solicitar, por carta, a colaboração do representante do governo português no Brasil.

"O que com o maior empenho eu lhe venho pedir agora é que você queira patrocinar, por meio da sua alta influência na colônia portuguesa do Brasil, este tão importante quanto melindroso projeto.” (Rodrigues Cavalheiro, A evolução espiritual de Ramalho, p.120)

A despeito de todo o interesse despertado, a idéia da subscrição brasileira à família de Eça de Queirós acabou sendo posta de lado quando se soube que à viúva repugnava por completo esta forma de auxílio.

${ }^{297}$ Rodrigues Cavalheiro, A evolução espiritual de Ramalho, p. 118.
} 
Ramalho confessa à filha - como se falasse consigo mesmo: "gosto de voltar a este meu antigo pouso" ${ }^{\prime 298}$.

No dia 8 de setembro escreve de Florença ao próprio genro, Antônio Ramos, uma carta e nela a certa altura diz o seguinte: "Vou ver se ainda aqui tiro tempo para principiar a escrever para a Gazeta e para lançar (literariamente) essa lembrança no espírito dos nossos compatriotas e dos brasileiros que ainda por lá me lerem"299. Ramalho estava se referindo àquela proposta do conde de Arnoso para a subscrição pública à família de Eça de Queirós, proposta da qual ele teria a incumbência de lançar a idéia no Brasil.

São três passagens de três cartas diferentes que não deixam dúvida de que algum entendimento deve mesmo ter havido entre o jornal e o escritor. Mas, a despeito deste provável entendimento e dos insistentes anúncios, nada foi publicado até a edição de domingo, 22 de setembro de 1901, quando saiu um texto firmado com seu nome. Não se tratava, no entanto, de matéria escrita especialmente para o diário brasileiro, mas de uma simples reprodução da carta que Ramalho havia enviado aos jornais portugueses, em 31 de agosto, comunicando o falecimento de Eduardo Prado.

Acontece, porém, que passados quatro dias após aquela publicação, a Gazeta de Notícias, surpreendentemente, estampa, na última coluna da primeira página, após sete meses de silêncio, novo comunicado sobre a retomada dos trabalhos de seu antigo colaborador.

As primeiras cartas com que o nosso eminente escritor Ramalho Ortigão reata as suas colaborações nesta folha, e que brevemente, encetaremos, serão referentes à "questão religiosa" agitada em Portugal pelo caso Calmon, no Porto. ${ }^{300}$

E foram realmente publicadas, entre setembro e outubro, quatro "Cartas Portuguesas", as três primeiras a respeito da aludida questão religiosa e a última tinha a viagem como tema. Porém, tão somente a estas quatro

\footnotetext{
${ }^{298}$ Ibidem, p. 147.

${ }^{299}$ Ibidem, p. 148.

${ }^{300}$ Gazeta de Notícias, 26 de setembro de 1901.
} 
cartas e àquela reprodução ficaram restritas as colaborações de Ramalho Ortigão à Gazeta de Notícias, neste ano de 1901.

A partir deste ano há um grande silêncio e nada é firmado com seu nome nos anos de 1902 e 1903, para no segundo semestre de 1904, mais precisamente no domingo, 27 de novembro, o diário brasileiro reproduzir pequenos trechos de um discurso de Ramalho Ortigão, proferido em Vila Nova de Gaia na inauguração de uma estátua de Soares dos Reis, esculpida por Teixeira Lopes, artistas que ele tanto admirava. Depois disso, novamente o silêncio para os anos de 1905, 1906 e 1907.

Durante esta fase silenciosa do antigo colaborador, as crônicas enviadas de Lisboa para a Gazeta de Notícias, eram assinadas por D. João da Câmara $^{301}$ que aceitara o convite, levado por Lino de Assumpção, para colaborar no jornal. É possível que este convite ao dramaturgo português para figurar no quadro de correspondentes assíduos da Gazeta tivesse por fim suprir a ausência de seu principal correspondente em Lisboa, um tanto quanto afastado da imprensa brasileira. $\mathrm{E}$ é bem possível mesmo, porque, coincidência ou não, após o falecimento ${ }^{302}$ de D. João da Câmara dá-se, pouco a pouco, o seu retorno às páginas do jornal.

Um mês após a morte de D. João da Câmara, D. Carlos, juntamente com seu filho D. Luís, príncipe herdeiro, são assassinados no Terreiro do Paço. Pouco depois destas ocorrências, a Gazeta de Notícias publica o artigo intitulado "Sua majestade a rainha", escrito em 1895, de encomenda, para os Perfis Contemporâneos, oportunidade aproveitada por Ramalho para enaltecer as qualidades de dona Amélia, nos papéis de rainha, de esposa e de mãe.

Mas tudo não passava de um simples recurso para ganhar tempo e promover, colocando novamente em evidência o nome de seu antigo correspondente. A publicação daquele texto era assim uma espécie de

\footnotetext{
301 D. João da Câmara (1852-1908), dramaturgo português, autor de comédias e peças de conteúdo histórico, além de poeta e cronista de jornais.

${ }^{302}$ D. João da Câmara faleceu em 2 janeiro de 1908, aos cinqüenta e seis anos de idade, merecendo de Ramalho Ortigão uma pequena e singela homenagem pública em forma de texto escrito para o jornal $O$ Ocidente, oportunidade em que rememora um casual encontro à porta de um teatro, de onde seguiram juntos em tipóia de praça a conversar amenidades.
} 
estímulo a picar, preparando, o espírito do leitor para a surpresa que o jornal estava the reservando. Tanto isto era verdade que no domingo, 8 de março, aparece em duas colunas da quinta página o anúncio cujo conteúdo já era mais ou menos esperado por todos:

A Gazeta de Notícias publicará na próxima quarta-feira um magistral artigo do notável escritor português Ramalho Ortigão que o escreveu especialmente para esta folha, atendendo a um pedido feito em telegrama pela Gazeta ao seu antigo e eminente colaborador. $^{303}$

Na segunda-feira a chamada se repete e na terça é estampada, logo na primeira página do jornal, uma gravura do escritor, em perfil, sentado, já com os cabelos grisalhos, estampa que servia de ilustração para uma longa legenda de conteúdo biográfico.

Finalmente, na quarta-feira, 11 de março de 1908, é publicado aquele que se tornaria um dos mais conhecidos e citados textos do autor, o artigo intitulado "Rei D. Carlos, o martirizado", em uma edição histórica, tanto para o jornal quanto para o escritor. Para se ter uma idéia do destaque dado àquela matéria basta saber, por exemplo, que toda a primeira página foi tomada por ela. O expediente, a coluna de telegramas e tudo mais que costumeiramente nela era publicado foi suprimido. Abaixo do título, Gazeta de Notícias, tudo era Ramalho Ortigão. O nome da seção que trazia sua correspondência, as velhas e conhecidas "Cartas Portuguesas", que remontavam há mais de trinta anos e que há algum tempo não se viam estampadas nas páginas do jornal, viera, desta feita, impresso em letras garrafais. O título do artigo, "Rei D. Carlos, o martirizado", também mereceu destaque e ao final da última coluna o diário brasileiro transcrevia no original, em francês, um texto de Michelet, extraído do tomo XVII da Histoire de France, que Ramalho havia citado em tradução própria e, "para retificação de qualquer equívoco"304, cuidara de enviar junto o original. Michelet traça nesta parte de sua obra um perfil do primeiro ministro de Luís XVI, o economista Jacques Turgot, do qual Ramalho, aproveitando a descrição do historiador francês,

\footnotetext{
${ }^{303}$ Gazeta de Notícias, 11 de março de 1908.

${ }^{304}$ Ramalho Ortgão, Últimas farpas, p. 231.
} 
estabelece uma comparação com João Franco, o último presidente do conselho de ministros de D. Carlos. Ambos governaram em regime extraparlamentar, com a diferença que, enquanto Luís XVI, não resistindo a pressões, demitiu Jacques Turgot, D. Carlos, contrariando grande parte da opinião pública portuguesa, manteve João Franco até o trágico desfecho do dia primeiro de fevereiro de 1908.

$$
\text { Contradição flagrante na lógica das coisas: em }
$$
circunstâncias análogas, Luís XVI morre por ter tido a fraqueza de demitir Turgot; D. Carlos morre por ter cumprido o arriscado mas patriótico dever de não demitir João Franco. ${ }^{305}$

"Rei D. Carlos, o martirizado" foi escrito poucos dias depois do regicídio, portanto, ainda sob o impacto violento dos acontecimentos e mais que um sincero protesto, um clamor de justiça, é um pungente e legítimo grito de dor. Talvez tenha sido este um dos maiores golpes sofridos por Ramalho Ortigão, só mesmo comparável à perda daquele que sinceramente considerava um grande e verdadeiro amigo: Eça de Queirós. E foi nas páginas da Gazeta de Notícias que estampou e tornou público todo sentimento de amargura que Ihe causou a tragédia do Terreiro do Paço.

Ramalho admirava sinceramente este rei que se considerava um membro suplente do grupo dos "Vencidos da Vida", merecendo, de sua parte, Carlos de Bragança, todo respeito como homem, como rei e como artista. Consagrou-lhe um breve estudo de sua obra de pintor: retratos íntimos de figuras a óleo e a aquarela; quadros de paisagens, especialmente marinhas; esboços e desenhos a lápis, a pena e a carvão. Foi este estudo a sua colaboração no volume Sua Majestade El-Rei D. Carlos I e sua obra artística, livro publicado em Lisboa, logo após o regicídio e que hoje consta do volume II de Arte portuguesa.

As ocupações artísticas e científicas deste rei oceanógrafo que levava uma vida simples em seu retiro no Alentejo faziam a admiração do crítico que defendia a política por ele adotada e justificava a ditadura de João Franco, seu primeiro ministro, como a única forma de tirar Portugal do impasse 
(o atoleiro) em que se achava pelo desgastado rotativismo, considerado pernicioso demais para o país.

Na qualidade de bibliotecário do palácio da Ajuda, no exercício de suas funções, punha-se freqüentemente em contacto com ele e com membros da família real, assistindo às argüições das disciplinas a que, periodicamente, eram submetidos, em reuniões familiares, o príncipe real D. Luís Felipe, assassinado juntamente com o pai, e o infante D. Manuel, que, em decorrência dos acontecimentos, foi proclamado rei de Portugal aos 18 anos de idade.

De lamentar também seria o fato de saber encerrado um período tão confortável de sua vida como foram os últimos anos do reinado de D. Carlos e a consciência da fase extremamente difícil em que o país doravante iria enfrentar.

A edição da Gazeta de Notícias, em que a matéria foi publicada, esgotou rapidamente. Extraordinária repercussão na capital federal e em vários outros estados é o que enfatizava o jornal em suas edições dos dias 12 e 15 de março.

O artigo ainda foi, com autorização do autor, reeditado em opúsculos de 20 páginas, custeados por comerciantes portugueses radicados no Rio de Janeiro, para distribuição no Brasil e em Portugal, sempre no sentido de promover e divulgar seu conteúdo, assim como informavam os editores: "O intuito dos que promovem a reedição deste depoimento é torná-lo conhecido de todos..."306.

Logo após o assassinato de D. Carlos, João Franco, temendo pela própria vida, deixou Portugal e no exílio tomou conhecimento do artigo enviado por Ramalho à Gazeta de Notícias. Quando em 1924 publicou seu livro, Cartas de el-rei D. Carlos I, escrito em memória do rei sacrificado, João Franco, ao recordar a tragédia do Terreiro do Paço, enaltece a coragem do autor de tão "admiráveis e justiceiras páginas", e lembra que Ramalho foi um dos poucos e raros corajosos a pedir justiça em momento tão delicado. Recorda ele, ainda, que "no infortúnio e no exílio" o artigo de Ramalho, 
publicado no Brasil, foi, entre tantos outros, aquele que mais the serviu de "consolação e desvanecimento"307.

Após a publicação de "Rei D.Carlos, o martirizado", em 11 de março de 1908, nada mais a Gazeta de Notícias apresentou firmado com o nome de Ramalho Ortigão, até o dia 5 de fevereiro do ano seguinte, quando então republicou, com o título de "A tragédia do Terreiro do Paço", um pequeno texto escrito por ele especialmente para o jornal O Portugal, de Lisboa e que lá foi publicado com o título de "A tarde de 1 de fevereiro de 1908", exatamente no aniversário de um ano da morte do rei. O principal tema tratado neste pequeno texto de apenas uma coluna era o lamentável fato de, tendo decorrido um ano daquele atentado, ainda pesar sobre ele, no que diz respeito a investigação judicial, o mais inexplicável, senão comprometedor silêncio. Deplorando este fato e a morte do rei, seu amigo, Ramalho chega a dar a impressão de já pressentir, embora de forma ainda um pouco indefinida, a marcha inevitável da conspiração republicana que se anunciava.

Alguns dias depois desta republicação, quando um terremoto devastou o sul da Itália, a Gazeta de Notícias publicou um artigo de Ramalho Ortigão, intitulado "Sicília - sensações de arqueologia e de arte", em que relembra uma viagem feita sete anos atrás por esta ilha, percorrendo as ruínas dos templos dóricos, grego-sicilianos, que podiam ser vistos e admirados em Girgenti, Selinunte, Segesta e Siracusa.

Ainda neste de 1909, é publicada uma conferência do escritor, pronunciada na Sociedade de Conferências de Lisboa, que tinha por tema o "Juízo". Como era próprio de seu feitio, por um requinte de gentileza, fazia chegar uma cópia ao jornal acompanhada dos seguintes dizeres: "Deliberei, antes de a publicar na imprensa portuguesa, consagrá-la por meio da Gazeta de Notícias aos meus antigos leitores do Brasil" ${ }^{308}$.

Como se pode ver claramente, são trabalhos esporádicos, motivados por singulares acontecimentos de natureza geológica, política ou social. Aquele velho e conhecido correspondente, em Lisboa, a que os leitores

\footnotetext{
${ }^{307}$ Rodrigues Cavalheiro, A evolução espiritual de Ramalho, p. 422.

${ }^{308}$ Gazeta de Notícias, 15 de março de 1909.
} 
da Gazeta de Notícias estavam tão acostumados, só voltaria a funcionar, quase aos mesmos moldes daqueles tempos no que diz respeito à regularidade, após a revolução republicana de 5 de outubro de 1910.

E a forma como isto vai se dar é exatamente o assunto do próximo capítulo. 


\section{4 - As últimas "Cartas Portuguesas"}

\section{1 - O reinado de D. Manuel II}

No capítulo anterior foram focalizadas as colaborações de Ramalho Ortigão publicadas pela Gazeta de Notícias durante o período encerrado pela tragédia do Terreiro do Paço e a revolução republicana, sendo de notar que, além de ser numericamente irrisório o número destas colaborações, elas não fazem qualquer referência ao conturbado momento político que Portugal atravessava. Dão mesmo a impressão de que todos os sonhos de mudança e engrandecimento que Ramalho um dia acalentou para a pátria foram sepultados com o rei D. Carlos. Já quanto ao reinado de D. Manuel II, se nada tinha para elogiar também não se achava à vontade para criticar: afinal tratava-se de um menino que ele tinha visto nascer.

\section{E o que foi afinal este reinado do filho mais novo de D. Carlos?}

Sabe-se que logo após o regicídio foi organizado um governo de coligação monárquica que pôs em liberdade os presos políticos ${ }^{309}$, autorizou o regresso dos exilados e permitiu a circulação de jornais suspensos durante a ditadura de João Franco.

Esta coligação ministerial da monarquia era presidida pelo almirante Ferreira do Amaral e ficou conhecida como "ministério da acalmação". E para fazer jus à sua alcunha promoveu uma anistia tão ampla e irrestrita que chegou ao extremo de permitir a abertura de subscrições a favor dos filhos menores de Alfredo Luís da Costa e Manuel dos Reis Buíça, os regicidas mortos pela polícia no mesmo dia e no próprio local do atentado. Foi ainda este ministério e a sua política da "acalmação" o principal responsável pelo arquivamento do inquérito policial que tratava do assassinato do rei $D$. Carlos e de seu filho D. Luís, a despeito da atitude corajosa e isolada com que o conde de Arnoso, incansavelmente, trabalhava na Câmara do Pares para que se procedesse a uma investigação rigorosa e imparcial sobre o caso. No fundo,

\footnotetext{
${ }^{309}$ Entre estes se achavam: Afonso Costa, João Chagas, Egas Moniz, França Borges, Antônio José de Almeida, João Pinto dos Santos e o visconde da Ribeira Brava.
} 
esta política de tolerância e liberdade não passou de uma tentativa, passageira ao fim de contas, de pacificação do país.

Mas como reza o ditado: rei morto, rei posto, no dia 6 de maio de 1908 foi celebrada a cerimônia de coroação de D. Manuel II, praticamente um menino de dezenove anos de idade imbuído das mais sinceras intenções de entendimento e pacificação. Jovem e inexperiente se deixou influenciar pela mãe, a rainha D. Amélia, pela nobreza palaciana e por José Luciano de Castro, chefe do Partido Progressista e um dos principais nomes da política portuguesa durante seu reinado.

Pelos fins deste mesmo ano caiu o gabinete presidido por Ferreira do Amaral e junto com ele a estabilidade política, que deu lugar a uma sucessão de cinco ministérios, dos quais o primeiro deles, presidido por Campos Henriques, era ainda um ministério de coligação monárquica. Os que Ihe seguiram, porém, eram todos formados ou por regeneradores ou por progressistas, revelando a cisão que trazia de volta para o cenário político o rotativismo partidário que Ramalho Ortigão tanto condenou. $A$ instabilidade do regime era notória e se patenteou na efemeridade do ministério de Sebastião Teles que durando apenas um mês e três dias "nem chegou a merecer os cumprimentos protocolares" 310 .

Em maio de 1910, após uma série de boatos, era finalmente decretada a falência da Companhia do Crédito Predial Português, com rumores nos meios governistas de que a instituição tinha sido vítima de algum desleixo ou excesso de confiança, ou seja, pequenos descuidos administrativos, cujo verdadeiro significado, para os jornais republicanos, se traduziam por "grandes roubos". A simples demissão de José Luciano de Castro, um dos seus diretores, não foi suficiente para livrar o governo da monarquia das mesmas acusações.

Ocorrências como estas eram sempre transformadas em bandeira de luta pelos republicanos, que delas se aproveitavam para insuflar no povo um sentimento de rejeição à monarquia, facilitando assim a aceitação das novas idéias. Diante dos resultados positivos que a estratégia proporcionava ao

\footnotetext{
${ }^{310}$ Costa Lobo, in Oliveira Marques, História de Portugal, p. 48.
} 
movimento republicano, os governistas, assustados com seu crescimento, deram início a uma nova fase de repressão, com suspensões de jornais e prisões de jornalistas. Seguindo a orientação repressiva, o Juízo de Instrução Criminal passou a prender pessoas comprometidas com as sociedades secretas, decretando com esta atitude o fim da chamada política da "acalmação".

Estas sociedades secretas eram representadas, principalmente, pela Alta Venda, de caráter maçônico, além de outras conhecidas por carbonárias, com as quais o congresso republicano realizado na cidade do Porto em abril de 1910 havia selado um pacto, fazendo aprovar uma moção de solidariedade, na qual se achavam incluídas até algumas associações democráticas toleradas pelo governo.

E foram elementos ativos destas sociedades secretas ao lado de republicanos infiltrados no Exército que deram início, em princípios de outubro de 1910, à insurreição armada na cidade de Lisboa.

\section{2 - A revolução republicana em Portugal}

Na noite de 3 de outubro de 1910, enquanto no terceiro andar do prédio de número 106 da Rua da Esperança, no subúrbio de Belém, transcorria festivo o jantar oferecido por Hermes da Fonseca ao rei D. Manuel II, em um reduto secreto da cidade, silenciosamente, conspiravam, lado a lado, militares e chefes republicanos. Sabe-se que durante o jantar o presidente do conselho de gabinete, Teixeira de Souza, em vão tentou alertar os militares presentes para o perigo que ameaçava o regime monárquico. Mas se isto é que se diz e o que se sabe, não se sabe exatamente o que foi tramado na última reunião dos conspiradores, razão pela qual ninguém pode garantir que não tenha saído de seu bojo a decisão sobre os inesperados acontecimentos da madrugada do dia seguinte: revolta dos quartéis de Infantaria 16, no Campo de Ourique, e de 
Artilharia I, em Campolide, secundados pela revolta do quartel da Marinha, em Alcântara. Sintomaticamente, achavam-se por trás do movimento de sublevação alguns oficiais inferiores, sargentos e praças, aliados a um grupo de civis, comandados por Machado Santos, um dos chefes da Alta Venda.

Ao deixar os quartéis e ser impedido por tropas governistas de marchar em direção ao Palácio Real das Necessidades, o batalhão de revolucionários, contando algumas centenas de homens armados e municiados, inclusive de artilharia, acampou na Rotunda ${ }^{311}$, onde armou barricadas, resistindo aos ataques das forças fiéis à monarquia comandadas pelo capitão Paiva Couceiro.

No princípio da tarde, os cruzadores "Adamastor" e "São Rafael", fundeados no Tejo e em mãos dos republicanos, passaram a bombardear o Paço Real e o Rossio, onde se achavam concentradas as forças monárquicas. Aos disparos dos cruzadores seguiram os do quartel da Marinha. Este bombardeio concentrado provocou grande alvoroço e depois que um projétil cortou a corda e fez arriar o pavilhão real hasteado no palácio das Necessidades, as tropas governistas que se achavam ao redor do edifício deram tamanhas provas de medo e ânimo de defecção que deixaram de inspirar confiança a seus comandantes.

E mais que a falta de confiança, a própria constatação de que militarmente as forças fiéis à monarquia pouco poderiam fazer contra os revolucionários republicanos levou seus comandantes a aconselharem o rei $\mathrm{D}$. Manuel II a procurar abrigo na legação inglesa. Aí pouco permaneceu, seguindo para Mafra onde aguardou a chegada da mãe e da avó que se achavam em Sintra. Uma vez reunida, a família real foi escoltada por um pequeno destacamento da Escola Prática de formação de soldados até a praia da Ericeira, onde embarcou no iate "D. Amélia" em demanda da Inglaterra.

Neste mesmo país, D. Manuel II se casou em 1913 com uma princesa alemã e quase vinte anos depois morreu, sem deixar descendência, seguindo com ele para o túmulo o último representante da dinastia dos Braganças.

\footnotetext{
${ }^{311}$ Por seu formato circular, assim era conhecida a praça Marquês de Pombal.
} 
Para a sorte dos republicanos, não foi necessário o planejado golpe final que consistia no desembarque dos marinheiros, pela manhã do dia 5, sob o comando do almirante Cândido dos Reis, que depois foi encontrado morto na Azinhaga das Freiras, em Arroios, com uma única perfuração de bala, levantando a suspeita de suicídio.

Figura tutelar e virtual líder revolucionário, a morte deste que era o mais graduado oficial das forças armadas envolvido na conspiração deixou um vácuo, abrindo uma brecha por onde os membros do diretório do Partido Republicano ingressaram na revolução. $E$ foi no edifício da câmara municipal de Lisboa, pela manhã do dia 5 de outubro de 1910, que eles proclamaram a república em Portugal e passaram a comandar o país por intermédio de um governo provisório encabeçado pelo professor Teófilo Braga, republicano histórico que dividia o poder com aqueles que eram por todos considerados os verdadeiros chefes: os ministros Antônio José de Almeida, do Interior, e Afonso Costa, da Justiça.

Os pequenos focos de resistência que nos primeiros momentos surgiram, aqui e ali, não deram mostras de serem suficientes para impedir que o país como um todo aderisse ao novo sistema de governo. Tampouco as tentativas posteriores de restauração impediram que fosse para sempre decretado o fim da monarquia constitucional portuguesa.

Quanto a baixas sofridas, a revolução republicana portuguesa registrou um saldo total de aproximadamente 70 mortos e 300 feridos, em sua grande maioria, de indivíduos oriundos da classe civil.

Logo que se viu instalado no poder, o governo provisório teve a preocupação e o cuidado de impedir que um vento anárquico, capaz de subverter a ordem social vigente, soprasse pelo país. Era necessário, antes de tudo, acalmar a opinião pública nacional e salvaguardar os interesses internacionais, acenando com uma república ordeira e respeitável. Vivia-se ainda em uma Europa conservadora e predominantemente monárquica, em que a França e a Suíça figuravam como as únicas exceções. 
Seguiram-se outras medidas de caráter simbólico - servindo mais para dissociar do novo o velho regime - tomadas pelo governo provisório de Teófilo Braga: adoção de uma nova bandeira, de um novo hino, de uma nova moeda, de uma nova ortografia e de uma nova toponímia, alterando e substituindo as denominações dos logradouros públicos que lembravam o período da realeza.

Mas o que realmente marcou a república portuguesa em seu primeiro momento foi um cerrado combate ao clericalismo, com fechamento de conventos, abolição dos dias santos e do ensino religioso nas escolas, culminando pela lei de separação entre o estado e a igreja. Além disso, legislou no campo social com a lei do divórcio e de proteção aos filhos, bem como no campo cultural, com reformas na instrução superior.

São tais medidas e o próprio governo republicano os principais temas das últimas "Cartas Portuguesas" enviadas por Ramalho Ortigão à Gazeta de Notícias, de janeiro de 1911 a agosto de 1913.

4.3 - A retomada da correspondência para o Rio de Janeiro

A primeira página da Gazeta de Notícias do Rio de Janeiro, em sua edição de 5 de outubro de 1910, era quase que feita só de incertezas: Revolução em Portugal? Lisboa bombardeada? Prisão do rei? Quase, porque em um cantinho da página, o telégrafo trazia uma certeza: Hermes da Fonseca, que dali a dias seria empossado na presidência da república brasileira, achavase de passagem por Lisboa, onde havia se encontrado com o rei.

Dois dias depois destas indagações, o jornal despacha para a capital portuguesa um enviado especial a fim de se inteirar dos acontecimentos. E no dia 24 deste mesmo mês, estampa na primeira página um artigo, cujo título por si só tudo esclarecia: "A queda da monarquia".

Por este tempo, Hermes da Fonseca, que logo após as eleições presidenciais havia empreendido uma viagem à Europa a fim de visitar as 
fábricas de armas e examinar o material bélico necessário à modernização do exército brasileiro, já se encontrava no caminho de volta à pátria a bordo do encouraçado "São Paulo", recém-construído nos estaleiros ingleses. O encontro de Hermes da Fonseca com D. Manuel II, ocorrido a 3 de outubro de 1910, passou para a história e ficou registrado como o último ato oficial do último rei de Portugal.

A Gazeta de Notícias anuncia a posse de Hermes da Fonseca, para um mandato de quatro anos, a 15 de novembro de 1910 e logo em princípios do ano seguinte, mais precisamente na quinta-feira 2 de fevereiro, em grande estilo, muita ênfase e destaque especial, publica em três colunas no alto da primeira página o seguinte anúncio:

A Gazeta de Notícias pode ter hoje o prazer de comunicar aos seus leitores que está restituído ao corpo da sua colaboração efetiva o nome ilustre de Ramalho Ortigão. Volta o grande escritor, que se demitiu das funções públicas que exercia, a ocupar nesta folha a coluna que tanto honrou. ${ }^{312}$

Este anúncio que saiu na quinta, sai também na sexta e no sábado, sempre na primeira página, mas no domingo não, no domingo aparece, não mais na primeira, mas na quarta página e já não mais o mesmo anúncio, outro, este em letras garrafais, oito colunas e um novo texto: "Terçafeira 7, a Gazeta publicará a primeira das 'Cartas Portuguesas' de Ramalho Ortigão sobre os acontecimentos políticos e sociais de Portugal" ${ }^{313}$. E sempre seguindo na mesma senda da publicidade, na página cinco, ela estampa uma enorme foto do escritor, todo fardado, com o primeiro anúncio servindo de legenda.

Na segunda-feira, retornando à primeira página, novo anúncio e novo texto: "Publicaremos amanhã a primeira das "Cartas Portuguesas" com que Ramalho Ortigão volta a honrar as colunas da Gazeta de Notícias" ${ }^{\text {"14. }}$.

\footnotetext{
${ }^{312}$ Gazeta de Notícias, 2 de fevereiro de 1911.

${ }^{313}$ Idem, 5 de fevereiro de 1911.

${ }^{314}$ Idem, 6 de fevereiro de 1911.
} 
E, finalmente, no dia 7 de fevereiro de 1911 é publicada a primeira daquelas que seriam as últimas "Cartas Portuguesas", um conjunto fabuloso de mais de quinhentos textos que, por si só e a despeito de seu valor, serviria como um atestado da importância da imprensa brasileira na obra de seu autor.

Pela forma como o jornal anunciou e deu destaque ao acontecimento, era natural que esta primeira carta recebesse um tratamento especial do setor responsável pela diagramação das páginas. Das costumeiras oito colunas com que era dividida a primeira página, seis foram ocupadas pelo texto que assim tomou $75 \%$ de seu espaço. Além disso, reunidas duas a duas, as seis colunas se reduziram a três e o artigo foi todo impresso com um tipo especial, maior que o normalmente usado e próprio para as grandes ocasiões. Ao fim da primeira coluna, juntou-se em nota de rodapé a informação de que Ramalho Ortigão havia-se demitido "dos seus empregos de diretor da Biblioteca Real da Ajuda e de chefe de secretaria da Academia Real das Ciências de Lisboa" ${ }^{\prime 15}$. E isso realmente era verdade, ele havia tomado esta atitude por considerar-se um indivíduo estranho à nova ordem estabelecida, um cidadão à parte, para quem a república constituía "em sua aparente superficialidade o trágico desmoronamento instantâneo de todo um velho mundo"316.

Redigida a 7 de janeiro de 1911, exatamente um mês antes de sua publicação e três meses após a revolução republicana, o tema desta primeira das últimas "Cartas Portuguesas" reflete o estado de espírito do autor diante dos últimos acontecimentos políticos de Portugal, conjugando-se estreitamente, como ele mesmo diz, com a história de seu "regresso de velho filho pródigo à modesta e calma laboriosidade" ${ }^{317}$ de seu antigo ofício na casa que desde muito o havia acolhido.

E se assim era para ele, para os leitores da Gazeta de Notícias isto representava a retomada dos trabalhos de um velho e prezado amigo que nos últimos tempos só esporadicamente eles encontravam nas páginas de seu diário. A revolução republicana em Portugal se constituía assim na grande

\footnotetext{
${ }^{315}$ Idem, 7 de fevereiro de 1911.

316 Ibidem.

317 Ibidem.
} 
responsável pelo retorno daquele ausente "filho pródigo" que de agora em diante seria reintegrado ao quadro de colaboradores de seu jornal.

\section{4 - As últimas cartas e as Últimas farpas}

À exceção de "Carta de um velho a um novo", dirigida a João do Amaral e publicada apenas pelo diário A Restauração, e "Rei D. Carlos, o martirizado", que embora tenha sido publicado pela Gazeta de Notícias é, como se sabe, de 1908, salvo estes dois, repito, todos os demais textos que compõem o volume editado em 1916 com o título de Últimas Farpas outra coisa não são que este conjunto de "Cartas Portuguesas" publicadas antes pela Gazeta de Notícias durante o período que se estende de 7 de fevereiro de 1911 a 21 de agosto de 1913.

Dentre todos aqueles publicados e recolhidos em Últimas farpas, um único não foi escrito especialmente para o diário brasileiro, que apenas reproduziu, com a supressão do último parágrafo, um texto destinado a um número especial do semanário portuense $O$ Correio, de Joaquim Leitão e Álvaro Pinheiro Chagas. Escrito em Paris em 21 de janeiro de 1913, para o fim de assinalar a passagem do quinto aniversário do regicídio, foi publicado na Gazeta de Notícias no princípio de fevereiro, com o singelo título de "O rei D. Carlos".

Portanto, do conjunto de dezenove textos de que se compõe o livro Últmas farpas, "Carta de um velho a um novo" jamais foi publicado pelo jornal brasileiro, enquanto o artigo "Rei D. Carlos, o martirizado", publicado fora do período em questão, figura na obra como um apêndice.

As outras cartas foram enviadas, umas de Lisboa, outras de Paris, e apenas uma de Evian, na Suíça, embora tratassem, em sua esmagadora maioria, de questões relativas a Portugal. Se todas aparecem intituladas no livro, o mesmo não se dá em relação ao jornal, da mesma maneira como não são as mesmas as seqüências em que aparecem em um e outro veículo. 
Aproveita-se aqui a oportunidade para registrar que em Últimas farpas o capítulo intitulado "A raça" representa apenas uma das duas "Cartas Portuguesas" que trataram do assunto, justamente aquela publicada no sábado, 20 de julho de 1912, e que, certamente por questão de espaço, continua no dia seguinte, domingo, 21 de julho. Por lapso ou desconhecimento os editores do livro deixaram de recolher a continuação do dia 20, ou seja, o texto que ocupa o espaço de "Cartas Portuguesas" no dia 21.

Era procedimento comum uma carta se desdobrar e aparecer em mais de uma edição do jornal ${ }^{318}$, o que faz serem diferentes o número de textos em um e outro veículo.

É curioso saber que foi justamente este texto, "A raça", o único que Ernesto Rodrigues considerou autêntico e apropriado para incluir entre as Farpas escolhidas de Ramalho Ortigão, título da antologia que ele vinha preparando para a Biblioteca Ulisséia de Autores Portugueses. Desistiu, sem perceber que a continuação existia e estava sinalizada pelo termo "Prossigamos" com que se encerra a carta do dia 20. Deixa assim de fora de seu livro todos os textos das Últimas farpas. Aquilo não eram, a seu juízo, farpas, quando muito seriam dardos. Já o mesmo não se dá com Rodrigues Cavalheiro, autor de uma outra antologia, preparada para a Editorial Verbo que incluiu, desta obra, nada menos que cinco textos, particularmente por considerar que eles desmentiam a "acusação de decadência mental e estilística de seu autor"319. Opiniões divergentes que só fazem enriquecer a fortuna crítica desta obra.

\section{5 - Cartas enviadas de Lisboa}

As quatro primeiras destas últimas "Cartas Portuguesas", publicadas pela Gazeta de Notícias, foram enviadas de Lisboa, por onde

\footnotetext{
${ }^{318}$ De uma carta de Eça de Queirós, desdobrada em três edições, só foi recuperado o texto intermediário quando da preparação crítica do material enviado por este autor à Gazeta de Notícias. (Elza Miné, "A propósito de Thermidor", in Páginas flutuantes.)

${ }_{319}$ Ramalho Ortigão, Farpas escolhidas, introdução e seleção de Rodrigues Cavalheiro, p. 8.
} 
Ramalho, um pouco atônito com a revolução, se deixou ficar por um período de sete meses. Dentre elas, a primeira, enviada no dia 7 de janeiro de 1911, é uma daquelas que, embora não seja intitulada no jornal, é recolhida no livro com o nome de "A revolução de outubro". Como se pode deduzir pelo próprio título, o seu tema é a revolução republicana em Portugal, por Ramalho, irônica e resumidamente, assim descrita:

Poucas horas depois de um breve tiroteio de barricada no alto da Avenida e de um lacônico bombardeamento proveniente de uma insubordinação de marinheiros a bordo de um navio de guerra, proclamava-se perante Lisboa atônita e, imediatamente depois, perante a passividade do país inteiro, o triunfo dos revolucionários. ${ }^{320}$

Mas embora subestimasse a ação dos revolucionários da Rotunda, não deixava de consignar que em síntese o feito histórico pelo qual eles eram responsabilizados representava um verdadeiro "desmoronamento instantâneo de todo um velho mundo"321.

E a responsabilidade por este desmoronamento era inteiramente creditada ao reinado de D. Manuel II e à sua "política da acalmação". Adotada pelos sucessivos ministérios no ensejo de a todos agradar criou no próprio seio da monarquia "um partido enorme, apático, perigosíssimo de inércia - o partido dos descrentes"322, que se constituiu na maior das oposições.

Ramalho principia esta primeira das últimas cartas reportando-se às palavras de Victor Hugo, proferidas a um grupo de amigos reunidos em um jantar comemorativo de seu regresso de exilado em Guernesey, após a queda do império de Napoleão III e a proclamação da terceira república francesa. Dispondo-se a ler seus últimos versos aos convivas instalados em auditório, inicia o poeta esta audição por um breve exórdio que o autor da carta assim traduziu: " -Meus senhores, tenho setenta e quatro anos e recomeço a minha carreira" ${ }^{323}$.

\footnotetext{
${ }^{320}$ Idem, Últimas farpas, p. 8

321 Ibidem.

${ }^{322}$ Idem, p. 17.

${ }^{323}$ Idem, p. 7.
} 
E assim também Ramalho se sentia. Nascido em 1836, era como se ele, aos setenta e quatro anos de idade, recomeçasse a carreira, retomando o antigo ofício de correspondente de jornal. É bem verdade que o jornal já não era mais o mesmo dos primeiros tempos de sua colaboração e nem tampouco era a mesma a cidade por onde ele circulava. Sob a ação vigorosa do engenheiro e urbanista Pereira Passos, que abriu avenidas, canalizou córregos, saneou manguezais, perfurou túneis, o Rio de Janeiro havia passado por profundas alterações no traçado de sua rede urbana. Além das obras de infra-estrutura, o engenheiro teve sensibilidade o bastante para construir parques e jardins, embelezando sensivelmente a sua paisagem. Obviamente, a sociedade que passou a transitar pelas novas avenidas, respirando os saneados ares, não poderia ser a mesma das primeiras "Cartas Portuguesas", e nem tampouco seria aquela dos tempos em que ele, a esposa e a filha nela estiveram em "uma fugitiva estação de vilegiatura" ${ }^{324}$, que assim considerou a sua passagem pelo Brasil em 1887.

Eram outros os tempos deste reinício de atividade e já ninguém punha em dúvida a opção política de Ramalho Ortigão, um dos derradeiros remanescentes daquele alegre grupo gastronômico dos "Vencidos da Vida". Dificilmente haveria lugar para ele na grande imprensa de seu país que, como outro qualquer, nos casos de regimes instituídos pela força, historicamente, tem na sua grande imprensa - salvo as honrosas exceções - um canal sempre aberto às opiniões favoráveis, porém quase sempre fechado àquelas que são contrárias, por comprometedoras. Mas se por um lado o canal se fechava, por outro ele se abria e o diário brasileiro se apresentava como um luminoso e providencial farol capaz de irradiar a opinião contrária de um escritor que jamais se acovardou e, junto com Eça de Queirós, ajudou a mudar para melhor a imprensa de seu país.

E a princípio o negócio não deixava de ser interessante também para a Gazeta de Notícias. Se, no caso, Ramalho dispunha de uma tribuna respeitada, de onde poderia livremente dizer o que pensava do governo provisório e do novo regime imposto ao seu país, o jornal brasileiro por sua vez, contaria com a opinião de um crítico respeitado, um colaborador ilustre,

\footnotetext{
${ }^{324}$ Ramalho Ortigão, "O quadro social da revolução brasileira", in Revista de Portugal, p. 80.
} 
um dos poucos remanescentes daquela notável geração de 70 ainda em atividade. De certa forma, o mesmo se poderia dizer de Eça de Queirós, que embora morto em 1900, anos depois parecia em plena atividade pela obras póstumas que eram garimpadas em seus papéis. Eça que em vida sofreu, na pele de diretor da Revista de Portugal, restrições de possíveis colaboradores republicanos por acolher em suas páginas opiniões monarquistas. Porém, quanto ao diário brasileiro, não havia o que temer. O país vivia em segurança e seu regime de governo republicano estava mais que consolidado e não seria uma opinião isolada que iria abalar seus alicerces ou constranger correligionários. Quando muito poderia se ver contrariado, entre seus leitores, um ou outro imigrante português simpático ao novo regime. $E$ há que se levar em consideração ainda a capacidade de remuneração de uma revista que lutava para sobreviver e mendigava colaborações e um jornal economicamente estável, reconhecidamente bom pagador e que desde o início revelou sua verdadeira vocação, apresentando características próprias da imprensa moderna: muita notícia, muito anúncio e tiragem elevada.

Como já se deu a perceber, o principal alvo das críticas de Ramalho Ortigão nesta primeira carta é o governo provisório que "unicamente por serem republicanos os indivíduos que o constituem"325 se poderia chamar da "república". Um governo encabeçado por seu amigo Teófilo Braga, antigo correligionário da república das letras que na pena irônica do velho crítico seria responsável por levar às altas esferas do poder, junto com seu prestígio de incansável estudioso, a inconcussa proposta de "resolução de todos os problemas da governação indicados em dois ou três verbetes das suas enciclopédicas notas"326.

Logo após a posse, o governo provisório da república portuguesa, através do Ministério da Justiça, sob o comando de Afonso Costa, tomou algumas medidas, cujo radicalismo chocou a opinião conservadora. É importante ressaltar que eram republicanas todas as causas consideradas avançadas na época: o ensino laico, a luta operária, a libertação das mulheres. Mais que revolucionários, os republicanos eram evolucionistas, empenhados

\footnotetext{
${ }^{325}$ Ramalho Ortigão, Últimas farpas, p. 9.

${ }^{326}$ Idem, p. 19.
} 
em campanhas pelas reformas dos costumes, envolvendo a instrução, a saúde, o desporto, o turismo, causas pelas quais Ramalho Ortigão havia lutado toda a sua vida. Surpreendentemente, no entanto, ele passa a combater estas medidas, como é o caso da lei da imprensa e da lei das congregações religiosas, que ele agora considerava as duas das mais impróprias leis para "fundamentar a educação de gente livre" ${ }^{327}$. No que diz respeito à lei das congregações religiosas, parece não compreender que a república pretendia que houvesse um único culto oficial, o culto da pátria, representado pelos símbolos nacionais, como, por exemplo, o hino, a bandeira e os mortos ilustres.

Os republicanos combatiam a igreja romana como um obstáculo àquilo que eles queriam estabelecer: a adoração maçônica da humanidade por si própria (...) A pátria devia ser a única crença coletiva, sendo todos os outros cultos apenas tolerados como excentricidades privadas, perversões domésticas que não deviam interferir na vida pública. ${ }^{328}$

E como a religião, figurada pela igreja católica, remetia para um paraíso sem nacionalidade, alienando o povo e a nação de seus deveres cívicos, era então combatida.

Por sua vez, o anticlericalismo sempre funcionou, desde os tempos da propaganda, como uma senda pela qual poderia ingressar, aderindo ao republicanismo, a esquerda monárquica, uma facção política que nutria mesmo alguma expectativa sobre o novo regime. Portanto a esta facção ele nunca foi empecilho. À direita conservadora sim, e, mais que o anticlericalismo, Afonso Costa, ministro da justiça, por sua cumplicidade com José de Alpoim, acusado de implicação no assassinato de D. Carlos. O mesmo Afonso Costa que, depois de expedir mandato de prisão contra João Franco, deu aos franquistas, que contavam com a simpatia de Ramalho Ortigão, a plena consciência de que nada de bom poderiam esperar do novo regime.

Logo após a proclamação da república, a polícia praticamente desapareceu das ruas de Lisboa, do que se aproveitou um certo tipo de

\footnotetext{
${ }^{327}$ Idem, p. 12.

${ }^{328}$ José Matoso, História de Portugal, P. 413.
} 
revolucionários. Ardorosos republicanos de última hora e carbonários que se haviam conservado em casa durante os combates, subitamente, saíram às ruas e se puseram à solta pela cidade, vasculhando lugares que julgavam possíveis refúgios clericais; categoria na qual se incluíam conventos, redações de jornais monárquicos e residências de pessoas consideradas reacionárias. $E$ foi justamente nesta última condição que a casa de Ramalho recebeu, por expressa determinação de um tal Eusébio Leão, a visita de ativos e diligentes cidadãos encarregados da missão especial de averiguar se em seus "aposentos havia jesuítas armados e escondidos"329. É o próprio Ramalho quem faz questão de contar, aos seus leitores brasileiros, ao fim desta primeira carta, o que houve em sua residência.

Dois dias depois de aclamado o Governo Provisório, achando-me ausente de Lisboa, na quinta de uma das minhas filhas, em Linda-a-Pastora, fui distinguido com uma busca policial na casa do meu domicílio, na capital (...) Eram oito cavalheiros vestidos à paisana e armados de revólver, sob o comando de um bravo e honesto sapateiro, meu conhecido da antiga Rua de São Roque, hoje do Mundo. Não sei se todos eram igualmente artistas de sapataria. Sobre este particular Suas Excelências não me quiseram dar a confiança de se pronunciar. O que posso e devo consignar é que todos me deixaram penhoradíssimo pela afabilidade das suas maneiras e pela benigna lhaneza do seu trato. ${ }^{330}$

Como se isso realmente fosse possível.

Só mesmo recorrendo à ironia, à "santa ironia", como costumava dizer Eça de Queirós, para tratar sem rancor casos como este. É a fórmula preferencial dos espíritos superiores. E assim era Ramalho, um espírito desarmado e de trato pacífico, despido de agressividade. Não há maldade em suas ironias e não há lugar, em sua alma, nem para a perversidade, nem para o radicalismo, que jamais fizeram parte de seu temperamento. No perfil que dele traçou para a Renascença, de Joaquim de Araújo, Eça de Queirós dá como suas qualidades principais a força, a bondade e a alegria, uma alegria

\footnotetext{
${ }^{329}$ Ramalho Ortigão, Últimas farpas, p. 22.

${ }^{330}$ Idem, pp. 21, 22.
} 
serena ao lado de duas formas de bondade: "o amor dos pequenos, dos simples, dos fracos, dos oprimidos" e uma sensibilidade pronta, tão aflorada que uma bela obra ou uma boa ação bastavam para lhe depositar nos olhos o "brilho úmido da admiração enternecida"331.

Como bondade e justiça são qualidades irmãs, Ramalho Ortigão procurou ser justo em suas avaliações e, nesse sentido, se algum deslize cometeu, sempre se pautou pelo pronto reparo. Manteve sempre a serenidade em suas críticas que jamais destilavam maledicência e azedumes, comum a outro companheiro de sua geração, Fialho de Almeida, de linguagem impetuosa, sem limites em seus ataques, muitas vezes injustos e inoportunos. Enquanto Fialho de Almeida era um expansivo, Ramalho Ortigão era um contido.

Reservado e cauteloso, primava pela elegância do estilo até no uso de ironias, sempre finas e sutis, como a que se viu na passagem daquele relato que serve muito bem para aquilatar de seu gênio e compreender a forma pela qual poderiam, por ele, ser tratados republicanos capazes de atitudes como aquela que não poupava um cidadão pacato, sem filiação partidária e, a todo respeito, merecedor de maior consideração e estima por parte de seus compatriotas. É quase certo que hoje só se saiba da existência deste tal senhor Eusébio Leão pelo relato de sua vítima.

E é por isso também que não surpreende o teor destas derradeiras "Cartas Portuguesas". Elas serão o espelho da situação política de um país que, mesmo sendo conduzido por um velho amigo que sempre the mereceu o respeito, só Ihe causava desânimo, tristeza e desesperança e, conquanto ainda esbanjasse saúde e continuasse adepto das grandes caminhadas ao ar livre, já não mais via "o céu azul e o sol radiante de outrora" ${ }^{332}$, neste seu país de tantas transformações.

Ao finalizar esta primeira carta enviada de Lisboa, o correspondente, firmando compromisso, busca a aproximação e o diálogo com seus leitores, dispensando-Ihes um tratamento carinhoso de amigos aos quais

\footnotetext{
${ }^{331}$ Eça de Queirós, Notas contemporâneas, p.57.

${ }^{332}$ Ramalho Ortigão, Cartas a Emília, p. 170.
} 
podia ainda recorrer das "perturbações do seu ninho o foragido e alado pensamento de um escritor"333 de língua portuguesa.

Nove dias depois deste primeiro artigo, a Gazeta de Notícias voltava a publicar aquela série de chamadas que tanto servia para promover seu colaborador, quanto para indicar a data em que sairia a nova carta. $E$ nesse intuito, desde o dia 16 de fevereiro vinha publicando chamadas na primeira página, para no domingo, 19, estampar, não na primeira, mas na quarta página, em meio a outros anúncios menores e como se ele também fosse um simples anúncio, o seguinte texto: "Terça-feira, 21, a Gazeta de Notícias publicará a segunda das 'Cartas Portuguesas' de Ramalho Ortigão sobre os acontecimentos políticos e sociais de Portugal”334.

Ao que tudo indica, o redator do jornal encarregado do anúncio não havia ainda lido a matéria do correspondente que assim se abria:

$\mathrm{Na}$ precedente carta tentei, ainda que muito abreviadamente, esboçar a fisionomia do governo. Procurarei hoje, pela compilação de alguns dos seus mais característicos gestos, delinear o aspecto dos seus governados. ${ }^{335}$

E o que realmente Ramalho faz neste texto intitulado "Portugal antigo" não é nada mais que um apanhado histórico do povo português, desde a fundação do estado e a instituição da nacionalidade até a perda da independência na histórica batalha de Alcácer-Quibir, passando inclusive pela consolidação do império. Deixando um pouco de lado a questão política e demonstrando uma incomum erudição, ele põe em desfile personalidades masculinas e femininas que se destacaram durante este período nos mais variados ramos de atividade, principiando pelas grandes navegações com sua tradição de lutas e conquistas de toda uma vasta área espalhada pelo globo, regiões descobertas por homens como Diogo Cão, navegador que deu a conhecer a rota seguida por Vasco da Gama, colonizadas por homens como Afonso de Albuquerque, segundo vice-rei da Índia, que foi considerado o grande edificador do império colonial.

\footnotetext{
${ }^{333}$ Idem, Últimas farpas, p. 21.

${ }^{334}$ Gazeta de Notícias, 19 de fevereiro de 1911.

${ }^{335}$ Ramalho Ortigão, Ultimas farpas. P. 25.
} 
Do período de formação da língua portuguesa louva o Cancioneiro da Ajuda com seus cinqüenta e quatro poetas, citando nominalmente os reis trovadores: D. Dinis e D. Sancho I. Lembra também vários nomes de cronistas, naturalistas, dramaturgos e poetas que surgiram após este período de formação.

Fala da perfeição técnica atingida pelas artes, como a pintura nacional que "assume nos séculos XV e XVI um lugar que nunca mais depois disso tornou a ocupar no mundo" ${ }^{336}$, lembrando origem e nome de pintores famosos que retrataram personalidades e fatos da história de Portugal. E por aí vai citando outros nomes, que bem pouca gente conhece, de juristas, latinistas, lentes ${ }^{337}$ e reitores de universidades européias.

Confessa no final que este seu "quadro da mentalidade e da civilização de Portugal durante os primeiros séculos da sua história", Ihe saiu jornalístico demais, como colunas de noticiários, mas mesmo assim ainda serviria para que o leitor deduzisse da grandeza e do esplendor de Portugal durante o período em questão. E é com pesar que conclui esta segunda carta enviada de Lisboa.

Pelo cotejo desse tempo com o tempo que se seguiu ao fim da dinastia de Avis - época a que me referirei na próxima carta o leitor compreenderá o que é a fatal decadência de uma grande raça delida naquela "apagada e vil tristeza" em que Camões previu o fim da sua pátria. ${ }^{338}$

Segue a Gazeta de Notícias, na terça-feira, 14 de março de 1911, a publicação seriada das últimas "Cartas Portuguesas" com o artigo intitulado "O sebastianismo nacional", anunciado três dias antes de forma encomiástica e laudatória pelo jornalista, redator da chamada:

\footnotetext{
${ }^{336}$ Idem, p. 28.

${ }^{337}$ Francisco de Santa Maria, no Ano histórico, cita os nomes de portugueses lentes nas mais famosas universidades da Europa. Essa lista compreende cento e quinze nomes. (Ramalho Ortigão, Últimas farpas, p. 31).

${ }^{338}$ Ramalho Ortigão, Últimas farpas, p. 38.
} 
O brilhante analista e genial estilista continua nessa carta a analisar a atual situação de sua pátria, tendo principalmente em vista os antecedentes históricos do glorioso país. ${ }^{339}$

Se no "Portugal antigo" Ramalho Ortigão praticamente esquece da revolução de outubro, o mesmo não se dá com "O sebastianismo nacional". Aqui ele aproveita os antecedentes históricos para justificar e defender alguns de seus pontos de vista. É, por exemplo, nestes antecedentes históricos que encontra razão para acreditar na existência de sebastianistas em Portugal e no Brasil, mais de trezentos anos após a desastrosa e colossal jornada de África.

Por demais conhecido e disseminado em sua cultura é o sebastianismo em Portugal. Agora, quanto ao Brasil, citado em seu texto, pode até ser que a convicção lhe adviesse do conhecimento do episódio de Canudos, descrito por Euclides da Cunha em Os Sertões, livro que, embora jamais houvesse mencionado, muito provavelmente houvesse conhecido, tal o impacto causado na época de seu lançamento. Como se sabe, a obra foi publicada em 1902 e em sua terceira parte descreve o processo de extermínio do arraial de Canudos, onde se achavam concentrados cerca de oito mil crentes em um novo paraíso a ser inaugurado por D. Sebastião, após o juízo final. Antônio Conselheiro, o pregador errante que se fixou nas paragens do rio Vaza-barris, liderou este movimento messiânico que acabou identificado com a monarquia unicamente por ser monárquico seu líder. E foi esta a principal justificativa para seu massacre, com a cabeça de Antônio Conselheiro - cortada e levada do sertão para o litoral - fazendo delirar multidões em festa: "importava que o país se convencesse bem de que estava, afinal, extinto aquele terribilíssimo antagonista"340.

E se isto ocorreu no Brasil, em fins do século XIX, em Portugal "apareceram durante a primeira metade do século XVII quatro aventureiros"341 que ao se apresentarem como o prometido e esperado D. Sebastião, por um raro poder de convencimento, fizeram com que o povo, em sua ingenuidade pueril, acreditasse na identidade de todos eles. Mas este "delírio parcial

\footnotetext{
${ }^{339}$ Gazeta de Notícias, 11 de março de 1911.

${ }^{340}$ Euclides da Cunha, Os sertões, p. 352.

${ }^{341}$ Ramalho Ortigão, Últimas farpas, p. 40.
} 
coletivo" ${ }^{342}$, como assim era diagnosticado por "antigos alienistas", não se restringia apenas aos tempos passados.

Hoje mesmo (...) persistem resíduos depressivos e taras ancestrais que, ao mínimo abalo na elaboração cerebral dos motivos que determinem os seus atos, tornarão o povo português tão genuinamente sebastianista como no tempo dos seus antigos agitadores e profetas, o Bandarra e o sapateiro Simão Gomes. ${ }^{343}$

A idéia que Ramalho defendia e procurava passar aos leitores é a de que, se o povo português não mais acreditava no regresso de seu jovem rei, rutilante em sua armadura, de elmo empenachado de branco e o cálice sagrado nas mãos, seguia ainda aspirando a uma redenção nova e aceitando, "com uma credulidade inverossimilmente fanática e servil", todo redentor que Ihe aparecesse "palavroso e profético, bandarrista e sapateiral”" ${ }^{344}$, e via na república recém-chegada o caminho da salvação. Era o sebastianismo nacional voltando à cena pelas mãos dos revolucionários da Rotunda a tese de Ramalho.

Na edição do dia 2 de maio de 1911, a Gazeta de Notícias acusa o recebimento de nova carta e transcreve um artigo publicado em Portugal - no jornal $O$ Porto - junto a uma foto do escritor. Uma semana depois estampava na primeira página o seguinte anúncio:

Publicaremos na próxima quinta-feira, mais uma das primorosas cartas em que Ramalho Ortigão, o ilustre colaborador da Gazeta de Notícias, nos conta a marcha dos acontecimentos políticos em Portugal, carta onde se sente ainda palpitar a crítica superior com que Ramalho Ortigão traçou a sua obra formidável das Farpas. ${ }^{345}$

E tome louvações! Mas desta vez o autor do anúncio não deixa de ter lá suas razões. Se nos textos anteriores Ramalho havia tratado a república e os republicanos até com uma certa condescendência, agora esta derradeira carta enviada de Lisboa vem com novos propósitos, dando aviso e a impressão

\footnotetext{
${ }^{342}$ Ibidem.

${ }^{343}$ Idem, p. 40, 41.

${ }^{344}$ Idem, p.41.

${ }^{345}$ Gazeta de Notícias, 9 de maio de 1911.
} 
de que aquele antigo crítico dos tempos queirosianos ainda estava vivo e a qualquer momento poderia voltar à cena.

Publicada no dia 11 de maio, uma quinta-feira, como foi anunciado, não é intitulada no jornal, mas o próprio título com que foi recolhida em volume dá bem a medida de seu conteúdo: "A comédia política”. Logo de saída, faz ironias com algo que denominou o "Contencioso exibicionístico", por ele apresentado como uma repartição pública suplementar, composta de "repórteres, de fotógrafos, de uma filarmônica que toque desembaraçadamente a Portuguesa e da menina Deolinda Alves"346.

Esta menina, Deolinda Alves, que contava entre doze e catorze anos, era assim uma espécie de porta-bandeira que seguia após a música e diante da comitiva, em todas as cerimônias públicas do governo provisório. Quando esteve em casa do ministro do Brasil em Lisboa, em comitiva que homenageava o diplomata, "ricamente fantasiada de república, em veludo, cetim e ouro" ${ }^{347}$, nos pés meias de seda, na cabeça barrete frígio, à mão direita uma bandeira da república, à esquerda uma espada nua com a ponta voltada para baixo, causou um certo embaraço ao homenageado, que, segundo o correspondente, titubeava, sem saber exatamente o que, neste caso, determinava o cerimonial diplomático: um discurso ou uma boneca. Ramalho assegura a seus leitores da Gazeta de Notícias que o ministro ficou mesmo por algum tempo desconcertado diante daquela menina tão bizarramente composta naquela indumentária, jocosamente, qualificada de o mais "mimoso e bem ideado trajo de Jeanne d'Arc da Rotunda"348.

Mas é claro que Ramalho Ortigão não faz críticas ao novo regime imposto a Portugal com esperanças ou ideais de contra-revoluçionário, que nunca foi. A própria política partidária jamais o interessou, e isso nem mesmo nos tempos da monarquia, quando tudo lhe era favorável. Na realidade, o seu perfil não era o de homem de ação, mas de homem de pensamento e reflexão. Pensar, refletir e criticar, sempre no intuito da orientação, foi o caminho que

\footnotetext{
${ }^{346}$ Ramalho Ortigão, Últimas farpas, p. 52.

${ }^{347}$ Idem, p. 54.

${ }^{348}$ Idem, p. 55. As crianças, solicitadas a comparecer nas festas e comemorações cívicas em que eram obrigadas, sob rígida disciplina, a ouvir os discursos das autoridades, foram as grandes vítimas do regime republicano. Um mês após a revolução, cerca de 4.000 crianças das escolas foram levadas à Câmara Municipal de Lisboa para cumprimentarem o novo governo. (José Matoso, História de Portugal)
} 
procurou seguir, como se isso fosse mesmo um desígnio da Providência, e o desempenho a contento desta função, que ninguém de juízo lhe pode negar, quem dá atestado é a sua volumosa obra. E mais do que por princípio, por sensatez, realismo e senso de observação, jamais acreditou possível uma reação conjunta de organizações monarquistas, suficientemente constituídas, aparelhadas e em condições de promover uma reviravolta para a retomada do poder. Bastava lembrar o que havia ocorrido com os monarquistas brasileiros entre eles amigos particulares - fiéis testemunhas de pífias e malogradas tentativas contra-revolucionárias, para não acreditar em retomadas de poder.

E por ser assim, principia esta "comédia política" na qualidade de espectador que, confortavelmente instalado em sua cadeira de balanço, abre o jornal, passa os olhos pelo noticiário, constata a situação e friamente observa.

Debalde a pavorosa hidra da reação, por todo Portugal, e por boa parte do Brasil, segundo rezam os papéis, arrebita quotidianamente os tentáculos e espirra conspirações, rabeando nas ervas, sinistra, molanqueirona e estupenda. A polícia, olheira e vigilante, segue em bicos de pés o sinuoso frago da bicha, e já familiarizada com ela, toma-lhe o pulso, despiolha-a, assoa-a, amamenta-a e trá-la pela mão. ${ }^{349}$

E mantendo o bom humor garante estar a situação completamente sob controle, salva de contratempos e sem perigos para seus leitores brasileiros, em geral, e muito particularmente para descanso e quietação do "digno representante de Portugal no Rio de Janeiro"350, assegurando, para regozijo de todos, que o governo provisório da república portuguesa continua "provisoriamente governando mais firme, mais intemerato e mais prazenteiro que nunca" 351 .

E com ironias procura ridicularizar os chefes deste governo e todos aqueles que o representavam, flagrando atitudes e comportamentos anedóticos em que publicamente figurassem. É o caso, por exemplo, dos automóveis oficiais que, além dos representantes do governo, segundo o

\footnotetext{
${ }^{349}$ Ramalho Ortigão, Últimas farpas, p. 51.

350 Ibidem.

351 Idem, p. 52.
} 
correspondente, transportavam cada qual um fotógrafo e "desde que se apeie do automóvel, até que se torne a entrar nele, o governo toma uma expressão agradável e natural e o fotógrafo opera” ${ }^{\text {352. }}$

Em muitos aspectos, esta última das quatro cartas enviadas de Lisboa à Gazeta de Notícias faz lembrar as velhas farpas dos tempos do camarada Queirós, desmentindo, seja repisada, a acusação de decadência mental e estilística que lhe foi lançada durante a "apaixonada refrega política que caracterizou os últimos anos" ${ }^{353}$ da monarquia e os primeiros da república.

\section{6 - Cartas enviadas de Paris}

Convidado pelo governo suíço para compor um júri de arte e devendo, para tanto, encontrar-se em Berna no verão de 1911, Ramalho Ortigão deixa Lisboa no vapor holandês Frísia, que de regresso da América do Sul aí faria escala, precisamente, no dia 5 de maio.

Após o desempenho da missão com que o governo suíço o havia distinguido, fixa residência na capital francesa, de onde passa a enviar as suas colaborações para o Brasil. Formam elas um lote de onze cartas, das quais uma única não trata da política portuguesa; trata da literatura brasileira, sendo seu conteúdo desvelado por seu longo título: "Embaixadores de letras na Europa - Medeiros de Albuquerque - conferência brasileira na Europa". Seria esta também a única carta cujo tema estava inteiramente circunscrito a fatos ocorridos na França, uma vez que as demais, embora escritas em Paris, onde o autor se achava, quase que só tratavam de assuntos relativos a Portugal. Podia até acontecer que se aproveitasse de motivos franceses para efeitos de comparação, como o que se dá com a carta intitulada "O figurino francês". Há nela uma frase a respeito da situação política vivida pela França que serve

\footnotetext{
352 Ibidem.

${ }^{353}$ Ramalho Ortigão, Farpas escolhidas, introdução e seleção de Rodrigues Cavalheiro, p. 8.
} 
muito bem como exemplo disso: "Paris é neste particular o original em grande de que Lisboa é em pequeno ponto a cópia reduzida e caricatural”354.

A Gazeta de Notícias, por sua vez, ao tomar conhecimento desta mudança de ares de seu colaborador, registra o fato e comunica a seus leitores: "É datada de Paris a carta de Ramalho Ortigão que devemos publicar terça-feira próxima"355. Enviada em maio e publicada em julho, esta primeira carta postada de Paris, intitulada "Em trânsito", tem por tema de abertura um caso, por sinal bastante pitoresco, ocorrido momentos antes de seu embarque naquele vapor holandês que o levaria para Boulogne-Sur-Mer.

Fanfarronice quixotesca, que fez atrasar o embarque em mais de três horas, resultado de uma estapafúrdia investigação da polícia portuguesa que levou do vapor em lancha para terra, preso, um casal de brasileiros suspeitos do grave crime de dirigir, no Rio de Janeiro, uma Liga Monárquica. Episódio burlesco, temperado com arbítrio e prepotência das autoridades do país, atuando em navio de bandeira estrangeira, atracado no porto de Lisboa para movimentação de cargas e de passageiros, que Ramalho trata humoristicamente como um episódio de bufonaria próprio de farsas ou de operetas. Sem deixar transparecer qualquer ressentimento, embora ele próprio fosse uma das vítimas, registra este equívoco das autoridades portuguesas que, depois de tanto constrangimento e humilhação, devolvem ao vapor o casal com todos seus pertences para o prosseguimento da viagem; isto porque o governo provisório da república "generoso e magnânimo, perdoara-lhes tudo, absolutamente tudo, tudo o que eles não fizeram e tudo o que a polícia lhes fez..." 356 .

Censura alegre e trocista, boa para fazer rir Eça de Queirós, que adorava as suas farpas e seguramente aplaudiria o bom humor deste velho camarada, capaz de revelar, ainda que em meio a contrariedades, o lado faceto da vida.

E como ele estava em trânsito, o tema desta carta que em sua primeira parte trata de coisas de Portugal, na segunda trata de coisas da

\footnotetext{
${ }^{354}$ Idem, Últimas farpas, p. 110.

${ }^{355}$ Gazeta de Notícias, 9 de julho de 1911.

${ }^{356}$ RamalhoOrtigão, Últimas farpas, p. 68.
} 
França, mais especificamente daquelas coisas de Paris que não se viam em Lisboa. Os aspectos mundanos da cidade eram como ímãs que atraiam e ele então, pondo um pouco de lado a política, segue até o Luna Park, propondo-se "intermediar o divertimento físico com o imoral”357 e, por dez sous, fazer correr o reposteiro e assistir ao espetáculo de Le déshabiller d'une parisienne, que assegura a seus leitores brasileiros ter sido decepcionante, dado que foi "quase pudico".

Talvez por isto mesmo, põe de parte este tipo de divertimento e volta à carga, fazendo lembrar Eduardo Prado, que mais de vinte anos antes, também de Paris, por meio de uma revista portuguesa, manifestou seu descontentamento com a recém-fundada república brasileira. Agora, desta mesma cidade, só que por meio de um jornal brasileiro, era Ramalho quem fazia observações críticas a respeito da recém-fundada república portuguesa.

E para dar prosseguimento a estas observações, a Gazeta de Notícias, na quarta-feira, 30 de agosto de 1911, traz na primeira página em duas colunas a seguinte informação:

Ainda de Paris é datada a carta que recebemos do notável escritor luso Ramalho Ortigão. Publicá-la-emos na próxima segunda-feira. Ramalho Ortigão intitulou-a "Recapitulando". Esta carta trata da atual situação da república portuguesa, da crise que ela atravessa e indaga qual das fórmulas a novel república seguirá - a França ou a Suíça? ${ }^{358}$

A chamada se repete no dia seguinte e quatro dias depois é publicada a carta, não com aquele título anunciado, mas sim com o de "Breve recapitulação", o mesmo com que foi recolhida em volume. Na verdade, a questão do modelo republicano, de que fala o jornalista autor do anúncio, serve apenas de introdução a esta carta cujo verdadeiro propósito seria demonstrar ao leitor, em um apanhado geral, a série de malogros representados pela revolução republicana e democrática ao longo da história. Para Ramalho, a democracia que havia falhado na Grécia e em Roma e que o mundo moderno

\footnotetext{
${ }^{357}$ Idem, p. 72.

${ }^{358}$ Gazeta de Notícias, 30 de agosto de 1911.
} 
revivia e experimentava sem grande êxito ${ }^{359}$, ainda não dava "suficientes garantias como fórmula de agasalho doméstico"360 para uma convivência pacífica. E como se isso não bastasse, ele não via motivos relevantes que suscitassem conseqüências mais sérias e justificassem a revolução republicana ocorrida em seu país, uma vez que, a seu entender, no Portugal da época "não havia despotismo, não havia opressão e não havia fome" ${ }^{361}$, as principais forças motrizes de convulsões políticas e sociais. Por conseguinte, se não era uma questão política, nem econômica, nem social, só poderia mesmo ter sido uma questão "pura e exclusivamente pessoal"362 a mola mestra da ação revolucionária. Daí a principal razão de sua desconfiança no regime recém-instaurado. E não era ilógico este raciocino, dado o caráter pessoal com que se poderia encarar aquela estapafúrdia busca em sua residência.

Quanto àquela questão do modelo de república a ser adotado pelos comandantes da política portuguesa, mencionada no anúncio e utilizada na introdução, este assunto mereceu, posteriormente, um novo tratamento, com um desenvolvimento maior em uma carta, sugestivamente, intitulada " $O$ figurino francês". Esta é uma daquelas colaborações em que Ramalho se apropria de motivos franceses, neste caso específico o sistema político e institucional adotado por eles, para demonstrar o erro em que vinham incorrendo as autoridades portuguesas ao copiar semelhante modelo. É com muita propriedade e discernimento que lembra a seus leitores: "A vantagem dos pequenos povos modestos que vão atrás dos outros na marcha da civilização é a de evitar no caminho os tropeções e as quedas dos que vão adiante" $^{363}$. Mas, pelo que vinha observando, a república portuguesa era a "retardatária obtusa" para quem a lição parecia inútil, quando seguia à risca e não evitava os "tropeções e as quedas" dos que iam adiante. É aquela mesma

\footnotetext{
${ }^{359}$ Veja-se, por exemplo, o que ele diz da democracia francesa: "O regime estabelecido por terceira tentativa, há quarenta anos e tendo até hoje devorado quarenta e dois ministérios, um pouco mais de um ministério por ano, é ainda ao presente um regime provisório". ( Ramalho Ortigão, Últimas farpas, p. 111)

${ }^{360}$ Ramalho Ortigão, Últimas farpas, p. 78

361 Idem, p. 79.

362 Idem, p. 83.

363 Idem, p. 109.
} 
idéia: Paris é, em ponto maior, o original de que Lisboa é a "cópia reduzida e caricatural" ${ }^{364}$.

Conquanto propusesse ao país modelos ou figurinos republicanos mais bem desenhados, como seriam os Estados Unidos e a Suíça, a rigor, Ramalho não confiava nesta forma de governo devido à improbidade gerada pela decomposição democrática. Ele explica: as democracias haviam se convertido em propriedades exclusivas de castas oligárquicas que puseram a perder a idéia primitiva que a expressão latina, res publica, encerrava - o que é de todos. Além disso, estas castas tinham como prioridade a consolidação partidária representada pelo sucesso nas eleições, achando-se periodicamente subordinadas à expressão numérica que o resultado das urnas representava. É por isto mesmo que dizia haver apenas uma única diferença entre um rei constitucional e um presidente de república: "o rei é o presidente de uma nação, e o presidente é o rei de um partido"365.

Durante o período decorrido entre as publicações de "Breve recapitulação", que é de 4 de setembro de 1911, e "O figurino francês", que é de 18 de março de 1912 , a Gazeta de Notícias deu a público ainda mais dois textos: "Bom ano", em 15 de fevereiro e "O natalício da república - a menina deusa", em 11 de março deste mesmo ano. Desde o princípio até "O figurino francês", a seqüência de publicação das cartas na Gazeta de Notícias é a mesma das Últimas farpas, seguindo rigorosamente a data de sua emissão. Porém, a partir daí há divergência entre as seqüências publicadas em um e outro veículo. Ao que tudo indica o editor do livro seguiu aquela mesma orientação, diferentemente do que ocorreu com o jornal. Daí que o texto intitulado "Como nós éramos, como eles são", escrito em março de 1912 e que no índice do livro segue, como deveria mesmo ser, "O figurino francês", só foi publicado pela Gazeta de Notícias em 13 de janeiro de 1913, quase um ano transcorrido de sua emissão e depois de outras cartas. Parece até que por descuido havia sido guardado em uma esquecida gaveta.

Nesta carta - uma das mais interessantes deste conjunto enviado de Paris - Ramalho Ortigão faz uma espécie mea culpa, reconhecendo o

\footnotetext{
${ }^{364}$ Idem, p. 110.

365 Idem, p. 118.
} 
decisivo papel desempenhado pela geração de 70 na preparação do terreno por onde depois seguiram os revolucionários de 5 de outubro.

Quando em Portugal não havia senão conservadores de diversas marcas, que vinham todos da revolução liberal (...) eu e alguns do meu tempo entendemos que a sociedade portuguesa encharcava e apodrecia na subserviência de um parlamentarismo quase tão oco como o de agora, (...) e deliberamos acordar do seu letargo a consciência pública, a duches, a ventosas, a pontas de fogo, a buscapés, a empurrões e a cartoladas. ${ }^{366}$

Ele e "alguns" do seu tempo, que outros não eram senão Eça de Queirós, Guerra Junqueiro, Guilherme de Azevedo, Bordalo Pinheiro, Oliveira Martins, Ramalho Ortigão, Jaime Batalha Reis, Teófilo Braga, Manuel da Arriaga, entre outros, artistas e intelectuais que oriundos da Questão Coimbrã, do Cenáculo, das Conferências do Casino, exerceram um pontificado e foram responsáveis pelo realismo crítico, pela poesia militante, pela revisionismo histórico, pelo jornalismo de denúncia que, tudo somado, em última instância acabou servindo à propaganda republicana.

Alberto Ferreira em seus Estudos de cultura portuguesa - século $X I X$, no capítulo intitulado "1870: o nascimento do Portugal moderno", afirma que seria ilusório se não errado considerar a moderna história de Portugal iniciada com esta geração, da mesma forma que seria um erro grave "não the atribuir a importância e o valor que ela, de fato, desempenhou no desenvolvimento das idéias modernas" ${ }^{\text {367 }}$, difundidas pelo país em seu tempo.

Nestes princípios de um novo século, Ramalho estava plenamente consciente do quanto ele e seu amigo Eça de Queirós, no século anterior, haviam servido aos propósitos dos republicanos. Eles que, se nunca foram militantes do partido, foram ao menos considerados escritores simpáticos ao movimento, mesmo que não se definissem politicamente, como ocorre no episódio do lançamento do primeiro número de As farpas, quando então se espalhou o boato de que a publicação teria caráter republicano. Ao tomarem

\footnotetext{
${ }^{366}$ Idem, p. 123, 124.

${ }^{367}$ Alberto Ferreira, Estudos de cultura portuguesa - século XIX, p. 131
} 
conhecimento do que se vinculava na imprensa, procuraram esclarecer a opinião pública através de uma carta publicada pelo Diário Popular, oportunidade que aproveitaram para honestamente repelir a qualificação de republicana para seus opúsculos, se por isso se entendesse que eles representavam o eco de "corrilhos subterrâneos, sem ciência e sem consciência" 368 , mas que de maneira natural e satisfatória a receberiam se pela expressão "república" se entendesse o bom senso e a justiça, virtudes de que sentiam falta nos partidos políticos existentes.

E muito mais que em As farpas, foi em O António Maria, ao lado de Rafael Bordalo Pinheiro que Ramalho mais contribuiu para a divulgação dos novos ideais, e a tal ponto foi tido por republicano que disso resultou um tocante arrefecimento de cordialidade entre as pessoas com as quais "mantinha mais ou menos afetuosas relações sociais"369.

Os sorrisos que por um resto de contenance me eram ainda conferidos, quando não escorriam fel escorriam gelo: e o esforço empregado por alguns dos meus amigos, para amenizar aos meus olhos a expressão instintiva de seu desagrado, era tão intensa, que chegava a tornar-se compungente. ${ }^{370}$

É muito engraçado o aspecto dúbio desta questão, pois se isto se dava com pessoas de seu relacionamento, o inverso acontecia com pessoas do relacionamento de Bordalo Pinheiro, para as quais a participação de Ramalho em O António Maria despopularizava a folha por um "repugnante posto que misterioso fedor de aristocracia" ${ }^{371}$ atribuído à sua prosa.

E talvez se ache aí a razão pela qual, sem jamais se filiar a qualquer partido político, tenha sido considerado republicano pelos monarquistas e monarquista pelos republicanos. O que poucos sabiam, no entanto, é que para ele as formas de governo eram uma questão inteiramente secundária, posto que, bem pouca diferença havia entre a monarquia parlamentar e a república democrática. Para ele, as questões econômicas e

\footnotetext{
${ }^{368}$ Ramalho Ortigão, As Farpas XV, p. 249.

${ }^{369}$ Idem, As farpas IX, p. 176.

${ }^{370}$ Ibidem.

${ }^{371}$ Ibidem.
} 
sociais sobrepunham-se, na condução do povo, ao problema político. Em princípios da década de 1870 ele já pregava: "A questão grave que hoje preocupa os povos não é de como se há de distribuir o poder, é de como se há de distribuir a riqueza"372.

Vale frisar que, Ramalho e Eça, não estiveram sozinhos nesta cruzada pela remodelação da sociedade portuguesa. Toda uma geração participou ativamente desta empreitada, caminhando junto e com o mesmo empenho. Verdadeiro exército pela qualidade e valor dos combatentes que formavam alas e fileiras, marchando lado a lado. E eram eles: Eça de Queirós e Ramalho Ortigão, Antero de Quental e Batalha Reis ou Oliveira Martins, Guilherme de Azevedo e Rafael Bordalo Pinheiro ou Guerra Junqueiro, além de outros mais.

Naturalmente que com o passar do tempo surgiram divergências nos métodos e processos de remodelação social que passaram a adotar. Como bons socialistas que eram, Oliveira Martins e Antero de Quental, por exemplo, trabalhavam para que as transformações ocorressem de baixo para cima, enquanto Ramalho, comungando com Mousinho da Silveira, personagem histórico de sua admiração, considerava que a revolução necessária prescindia de uma radical mudança das formas de governo, bastando para tanto uma alteração radical e mais profunda das instituições sociais. A certa altura de "Como nós éramos, como eles são", falando por ele e por Eça de Queirós, ao recordar as primeiras publicações de As farpas, afirma categórico: "Figuravase-nos por outro lado não ser por meio de revoluções, mas sim por meio de simples revulsivos, que se tratam as atonias sociais" 373 .

Se Antero de Quental e Oliveira Martins queriam as mudanças e as transformações de baixo para cima, Ramalho as desejava de cima para baixo, pois acreditava que era "pelo saneamento dos indivíduos que se consegue a saúde das coletividades" ${ }^{374}$, saneamento este que, de forma

\footnotetext{
${ }^{372}$ Ramalho Ortigão, As farpas IV, p. 111.

${ }^{373}$ Ramalho Ortigão, Últimas farpas, p. 127.

${ }^{374}$ Ibidem.
} 
discutível, ele supunha que a "influência das élites sobre a obtusidade das massas" ${ }^{375}$ pudesse proporcionar.

Pequenas divergências, acentuadas pelo tempo, que não impediram, porém, de serem na mocidade sempre destemidos, irreverentes, expondo as mazelas do país, enquanto punham na berlinda alguns dos principais homens públicos da época. Quebrando-Ihes os "narizes de cera" com que se apresentaram nas assembléias, revelaram a indigência de seus direitos e demonstraram que, na grande maioria, estes homens públicos não eram nem "homens de ciência nem eram sequer homens do mundo"376; que não tinham princípios, idéias, ou ideais e, culturalmente, se achavam abaixo dos mais simples e corriqueiros leitores da Revista dos Dois Mundos e de outras publicações do mesmo gênero. $E$ depois de passar em revista o muito que fez a sua geração, conclui: "vejam lá os revolucionários da avenida se não fui com efeito eu, se não foram os do meu tempo quem desbravou o matagal e varreu o caminho em que eles agora marcham"377.

Mas, salvaguardando principalmente sua posição e a de seu amigo Eça de Queirós, considera que a semelhança entre os papéis representados pelos revolucionários de As farpas e pelos revolucionários da Rotunda estava restrita unicamente às circunstâncias de uns e outros empreenderem um movimento com propósitos de remodelar a sociedade portuguesa, no sentido de seu aprimoramento, mas ressalva que há aventuras e aventuras, não se podendo confundir o menestrel que vai, em noite de luar, de flor na lapela, abraçado à viola, cantar uma serenata "debaixo de um balcão, com o pilho que escala um muro de jardim para furtar galinhas" ${ }^{\text {378. Contra os }}$ menestréis de outrora, os ingratos de agora. Esses ingratos que não reconhecendo o seu papel na obra meritória da preparação, em vez de enviarIhe os cumprimentos fraternais, enviam-Ihe seus "esbirros" para devassar-Ihe a "casa suspeita dos miasmas deletérios que lá teriam perigosamente deixado cinqüenta anos de modesto trabalho independente, resignado e alegre"379. Igualmente ingratos eram também considerados os jovens jornalistas

\footnotetext{
${ }^{375}$ Ibidem.

${ }^{376}$ Idem, p. 124.

377 Ibidem.

${ }^{378}$ Idem, p. 127

${ }^{379}$ Idem, p. 125.
} 
republicanos que desconhecendo o papel por ele desempenhado sistematicamente o insultavam, exigiam que se calasse e pediam ordem de prisão contra seu filho José Vasco, comerciante bem sucedido na praça do Rio de Janeiro, de passagem por Lisboa, sobre o qual pesava a acusação, "perante as justiças da terra em que nasceu" ${ }^{380}$, do nefando crime de ser seu filho.

Nota-se por esta carta que passados mais de dois anos da ocorrência, Ramalho Ortigão não havia ainda esquecido a visita e o vasculhamento de sua residência na Calçada dos Caetanos, realizada pelos representantes da república que supunham ali um abrigo de clérigos.

Quando um periódico do Porto publicou um número especial dedicado á memória de José Luciano de Castro, falecido em 9 de março de 1914, Ramalho, em seu artigo de colaboração, após lembrar os alegres tempos em que juntos colaboraram no jornal de Cruz Coutinho, retoma o tema das invasões e lembra que a residência de José Luciano também havia sido assaltada à mão armada pelos republicanos "representantes da vindita popular" que arrombando portas a machado deram com a família a clamar por Deus que ao menos "poupassem a vida a um velho inerme, fulminado pela hemiplegia e recebendo os seus hóspedes tragicamente imobilizado na sua poltrona de paralítico"381.

Talvez tenham sido estas perseguições e atos de truculência que "despoletaram"382 em Ramalho Ortigão um anti-republicanismo mal controlado, de que estas Últimas farpas dão um testemunho insofismável. Este sentimento de revolta também ficou evidente em sua correspondência familiar e com os amigos. Ao conde de Sabugosa, dos Vencidos da vida, escreve de Paris a 11 de dezembro de 1913: "Ai de mim! Odeio ... E não posso, por mais que me domine, tratar senão pelo ódio aquilo que é odioso"383. E a forma que encontrava para ir "enxotando tristezas e amarguras" e seguir ganhando a vida era escrever, o mais amiudadamente que lhe fosse possível, artigos para a Gazeta de Notícias do Rio de Janeiro.

\footnotetext{
${ }^{380}$ Idem, p. 126.

${ }^{381}$ Ramalho Ortigão, Folhas soltas, p. 336.

${ }^{382}$ É este o verbo usado por Ernesto Rodrigues nas Farpas escolhidas, quando tratou deste assunto.

${ }^{383}$ P. Moreira das Neves, O grupo dos cinco, p.317.
} 
Mas, pelo que se deduz ao folhear o diário brasileiro, estes artigos já não mais causavam impressão, e isso refletia na direção do jornal que, por sua vez, já não mais apresentava o mesmo entusiasmo inicial. Dispensando aquelas chamadas enfáticas, ia agora quase que automaticamente apresentando aos leitores os textos enviados pelo escritor. Afinal, causava mesmo certa estranheza o fato de se falar de Portugal, ou mais especificamente do governo republicano instalado em Lisboa, estando-se em Paris, onde obtinha de segunda mão, repassadas pelo Diário de Notícias, as informações a respeito de seu país.

Além do mais, as suas críticas ao novo modelo político - mais sátiras que críticas propriamente ditas - restringiam-se, sobretudo, a algumas medidas de aspectos simbólicos, como alteração de nomes de logradouros públicos que se referissem ao período monárquico, mudança nas cores da bandeira e, acima de todos, o caráter anti-clerical do novo governo, sem levar em consideração ou dar a devida importância de que eram merecedoras muitas das medidas tomadas pelos republicanos no sentido da remodelação da sociedade portuguesa. Por exemplo, com relação à constituição republicana, a nova carta aprovada após longo e aturado debate em agosto de 1911 por uma Assembléia Nacional Constituinte eleita pelo voto direto, a única referência a ela feita diz respeito à crítica e à rejeição da emenda proposta por Teófilo Braga. Tomando conhecimento do fato pelo Diário de Notícias, muito provavelmente não sabia que Teófilo, tendo considerado o preâmbulo da carta um "fraseado retórico" propôs em substituição um novo texto que por ser considerado ainda mais retórico que o original foi por isto mesmo rejeitado pela mesa. Eram farpas humorísticas - embebidas no fel de quem pretende fazer desacreditar pelo ridículo - lançadas contra um governo recém-instalado, que se via entre o calor do arrebatamento e o fogo das preocupações, sempre em cuidados com uma possível reviravolta monarquista.

Natural seria que houvesse titubeios e as primeiras medidas não fossem de grande alcance dadas as circunstâncias e principalmente por se acharem no poder os republicanos de primeira hora, nomes importantes da fase de propaganda, hábeis neste papel, mais inexperientes no comando dos negócios públicos e no governo de um país. 
Embora estas últimas "Cartas Portuguesas" sejam trabalhadas à base da ironia e do gracejo permitem ao leitor aquilatar o grau de amargura em que vivia seu autor. "Por vezes tenho estado para abandonar de todo a pena dizendo-me que estou velho, desalentado e triste e que me devo calar" ${ }^{384}$, é o que escreve à esposa em 10 de maio de 1912. E pouco tempo depois da morte de Bernardo Pindela, em carta enviada ao conde de Sabugosa, confessa que embora nada the faltasse pelo lado material da vida, tinha na alma a negra impressão de que the faltava tudo: "a pátria extinta, e os amigos todos dispersos e emigrados, uns para terras estranhas, outros para dentro de si mesmos, outros para a morte....385. E mais enfática ainda é carta enviada ao genro Antônio Ramos, em justificativa do exílio voluntário pelo qual havia optado logo após a proclamação da república:

O mundo a que eu pertencia acabou. A sociedade de que eu fazia parte morreu. A solidão que me espera em Lisboa, onde toda a vida intelectual encharcou na hostilidade partidária dos espíritos, a solidão da alma, é mais horrível que no degredo entre selvagens pacíficos e mansos. ${ }^{386}$

Triste e ressentido, é natural que se sentisse diante da situação política e de todas as transformações pelas quais vinha passando seu país, desde o assassinato de seu amigo, o rei $\mathrm{D}$. Carlos, até a revolução de 5 de outubro, uma revolução que fez cair por terra todo o edifício que laboriosamente havia erguido com seu trabalho de burocrata exemplar e sua qualidade de grande escritor.

Ramalho Ortigão conheceu ao longo da vida, uma ascensão gradual, constante e efetiva que o transportou do colégio da Lapa, no Porto, onde iniciou a vida profissional como professor de francês, até à Biblioteca do Paço da Ajuda, em posto que o punha diretamente em contato com a família real e lhe dava a distinção e a prerrogativa de assistir às sabatinas a que eram submetidos os príncipes. Pouco tempo antes do assassinato de D. Carlos, cogitava-se em palácio a indicação de sua pessoa para figurar como Par do

\footnotetext{
${ }^{384}$ Ramalho Ortigão, Cartas a Emília, p. 170.

${ }^{385}$ P. Moreira das Neves, O grupo dos cinco, p. 315.

${ }^{386}$ Ramalho Ortigão, Cartas a Emília, p. 169.
} 
Reino e era tida como certa a sua presença na comitiva do rei em uma viagem que estava sendo planejada para o Brasil. Desde os tempos de os Vencidos da Vida, freqüentava os melhores salões da sociedade lisboeta e havia se tornado amigo de nobres influentes e chegados ao poder, privilégios de que muito se orgulhava. Mas eram tudo coisas do passado, tempos idos e vividos, e é com tristeza que lembra ao conde de Sabugosa: "Cada dia que passa nos cava mais o abismo que nos separa do passado"387. E já lá iam quase dois anos que se achava em Paris. É compreensível que a saudade apertasse com o passar do tempo e com a distância, longe de suas filhas, de seus netos, de sua casa, de sua terra, da qual costumava dizer: "terra a que mais quero, e por isso mesmo, talvez, aquela de que mais me queixo"388. Além disso, Ramalho tinha ciência de que Emília, sua esposa, não se adaptava muito bem às dificuldades do exílio e sentia ainda mais que ele a falta do conforto doméstico e de sua família. Em carta à filha Bertha, reconhece a situação e pressente que a mãe não poderá jamais adaptar-se como ele aos rigores do exílio: "Tem a nostalgia do conforto doméstico de sua casa"389. E ao conde de Sabugosa confessa: "A minha mulher formula todos os dias o plano de regressar a Lisboa para onde a arrasta irresistivelmente a saudade da casa, das filhas e das netas"390. E sabendo que não poderia continuar por muito mais tempo o seu exílio voluntário em Paris, confessa ao conde de Sabugosa que teria como única recompensa pela volta a sempre grata hospitalidade de sua casa, o palacete de Santo Amaro. O conde de Sabugosa era um dos poucos amigos que ainda restava.

Finalmente, Ramalho regressou em fins de março de 1913 e quatro meses depois, após the haver diagnosticado uma psicastenia, Dr. Moreira, seu médico, recomendou-lhe para tratamento desta moléstia, caracterizada por ansiedade, insegurança e fadiga psíquica, uma temporada em lugares serenos e tranqüilos. E é esta a razão pela qual a Gazeta de Notícias publica em agosto deste ano uma carta de seu colaborador enviada em julho de Evian. Evian, como se sabe, está localizada na Suíça, junto do

\footnotetext{
${ }^{387}$ Ibidem.

${ }^{388}$ Ramalho Ortigão, Últimas farpas, p. 191.

${ }^{389}$ Idem, Cartas a Emília, pp. 169, 170.

${ }^{390}$ P. Moreira das Neves, O grupo dos cinco, p. 317.
} 
lago Léman, bem próxima de Glion, local em que pela última vez estiveram juntos Ramalho Ortigão, Eça de Queirós e Eduardo Prado.

Portanto, Ramalho volta para Lisboa, passa "quatro estirados meses, apáticos, aturdidos e mudos"391 e segue logo após para Evian, de onde escreve a seus leitores brasileiros. Falando agora do que realmente viu e não daquilo que havia lido, diz do novo aspecto da cidade e de seus habitantes: operários, carbonários e funcionários; e diz também dos logistas, dos militares, dos janotas, das meninas elegantes e das mulheres dos ministros; comenta as transformações pelas quais passaram a cidade e seu país; fala de sua casa considerada agora um "inviolável tabernáculo" - com seu gato, companheiro que revê com a mesma alegria épica com que "Ulisses, de regresso a Ítaca, viu de novo o seu cão, segundo Homero"392.

De todo este inquérito, vale destacar a sua observação a respeito da expressão fisionômica dos operários que nada mais tinham daquela hostilidade apresentada nos primeiros dias da república, os tempos da invasão de seu domicílio. "Se foram algum dia arruaceiros e espancadores de ofício, mudaram de modelo de vida" ${ }^{393}$, garante ele para tranqüilidade dos viajantes e também para seu próprio sossego.

As derradeiras palavras desta carta publicada pela Gazeta de Notícias, na quarta-feira, 27 de agosto de 1913, com o título de "A nova Lisboa", acenam com promessas de um breve retorno: "Até amanhã" é a forma pela qual se despede de seus leitores. Quis, porém, o destino que não houvesse o amanhã e fosse esta a última carta enviada pelo escritor português ao jornalismo brasileiro.

\footnotetext{
${ }^{391}$ Ramalho Ortigão, Últimas farpas, p. 187.

392 Idem, 196.

393 Idem, 188.
} 


\section{Considerações Finais}

Qualquer um que tenha acompanhado a carreira jornalística de Ramalho Ortigão perceberia com clareza que seu desenvolvimento apresenta três tempos distintos: a fase inicial, representada pelos trabalhos realizados ainda nos tempos do Porto, sua cidade natal; a intermediária, pelo que fez nos primeiros anos de Lisboa, para onde se transferiu, e a derradeira, por tudo aquilo que realizou na condição de correspondente em Portugal da Gazeta de Notícias, do Rio de Janeiro. E vai notar ainda que, destes três períodos, o derradeiro é de longe o mais duradouro e o mais produtivo. Nenhum dos períodos anteriores -portugueses por excelência - pode ser comparado em volume com aquele desenvolvido na imprensa do Brasil. Amadurecido em sua arte, alcançou, Ramalho, maior nomeada como escritor na fase brasileira de sua carreira jornalística. A Gazeta de Notícias do Rio de Janeiro deu-lhe as condições necessárias para se dedicar à sua arte e produzir; e ele não decepcionou. Um número imenso de colaborações de qualidade inegável. Muitos textos antológicos publicados pelo diário brasileiro já se acham recolhidos em volume, mas existe ainda um bom número deles (inéditos em livro) inacessíveis à grande maioria dos leitores e que, sem sombra de dúvida, são merecedores de um resgate.

Com a fase brasileira de sua carreira literária não se pode comparar nem mesmo aquela dos primeiros anos de Lisboa, quando em colaboração com seu amigo, Eça de Queirós, lançou a primeira edição dos famosos folhetos, As farpas. Confirma o fato a sua segunda edição, realizada por David Corazzi, em 1887. Muita coisa recolhida, nesta que é considerada a edição integral de As farpas de Ramalho Ortigão, fazia parte do material enviado para a Gazeta de Notícias do Rio de Janeiro. E é natural que ele tenha produzido mais para esta do que para aquela publicação. Sabe-se que na época em que publicou As farpas, Ramalho desempenhava o papel reservado aos homens dos mil instrumentos - aquele que de tudo cuidava - enquanto que na Gazeta de Notícias passou a cuidar apenas da produção dos textos, do trabalho estritamente intelectual, sem preocupação alguma de ordem prática. Público certo e cativo, editores para cuidar dos entraves burocráticos e 
materiais, além de uma das melhores remunerações da época. Que mais poderia desejar?

O Brasil era um mercado cobiçado pelos escritores portugueses de então e bem mais que significativo foi o seu prestígio entre os brasileiros. Legendária e paradigmática era a imagem que encarnava: legendária pela fama de demolidor, paradigmática pelo interesse com que os principiantes acolhiam seus escritos e por eles se balizavam.

Servem de comprovação de seu prestígio e de sua influência a longamente abordada viagem que fez ao Brasil. Os três meses que passou entre os brasileiros deram ensejo a que lhe pagassem o devido tributo de consideração e respeito.

Por ser natural do Minho, Ramalho Ortigão representava uma das províncias que mais imigrantes enviava para o Brasil, razão pela qual se poderia supor que fosse a colônia portuguesa do Rio de Janeiro o público-alvo de sua correspondência. Não é descabida a suposição quando se lê e se nota que muitos textos enviados para o Brasil tinham como espelho o público português. São disto indiscutivelmente as Últimas farpas o exemplo mais bem acabado. Mas, mesmo as cartas que descreviam paisagens de Portugal e à primeira vista pareciam revelar este país aos brasileiros, estavam no fundo revelando Portugal aos portugueses - residentes ou não no Brasil. De outras terras então nem se fala. Serve de exemplo também deste olhar oblíquo o livro sobre a Holanda. De comparação em comparação, parece empenhado, do princípio ao fim desta obra que é o resultado da recolha dos textos originalmente enviados à Gazeta de Notícias, em demonstrar o quanto aquele país, com quatro séculos a menos de existência, se adiantava ao seu. Viaja pela Holanda, escreve para o Brasil, mas fala a Portugal.

E pode ser que tudo isto tenha sido de caso pensado. Quem garante que a Gazeta de Notícias, de olho nos anúncios, não se tenha dele aproveitado para falar à colônia portuguesa do Rio de Janeiro, fiel leitora do Jornal do Comércio? Além de numerosa, esta colônia tinha sob controle boa parte do comércio da cidade - interno e externo, no atacado e no varejo. 
Parece natural que o diário brasileiro voltasse ao menos um olho para este filão do mercado!

Se realmente isto ocorreu e foi interessante para o jornal, não deixou de ser interessante também para o escritor. E não só para ele, como para outros escritores portugueses do período. $\mathrm{Na}$ sua condição de jornal popular a preço acessível a muitas bolsas, alcançou a Gazeta de Notícias uma grande tiragem para a época, no Brasil, fato que Ihe proporcionou condições financeiras para abrigar em seu quadro de correspondentes escritores portugueses do porte de um Eça de Queirós, de um Guilherme de Azevedo, de um Mariano Pina, de um Jaime Batalha Reis, de um Ramalho Ortigão. Deste, especificamente, se poderia dizer o seguinte: a partir do dia em que passou a trabalhar para a imprensa brasileira, a Gazeta de Notícias se tornou o principal veículo propagador de suas idéias, de sua concepção de mundo, em alguns aspectos tipicamente oitocentista, em outros, surpreendentemente atual.

Vinculado ao desejo de encarecer as relações estreitas mantidas por Ramalho Ortigão com a imprensa brasileira, o levantamento exaustivo e rigoroso de todos os textos enviados por ele à Gazeta de Notícias do Rio de Janeiro, constante deste trabalho, viabiliza e facilita a preparação de um volume daquelas colaborações presentes no jornal, mas não localizadas em coletâneas do autor. Estariam elas assim mais acessíveis ao público e poderiam resultar em subsídios indispensáveis a futuros estudos sobre a participação portuguesa no jornalismo brasileiro, sobretudo no último quartel do século XIX. 


\title{
SEGUNDA PARTE
}

\author{
A colaboração de Ramalho Ortigão \\ na Gazeta de Notícias (1877 - 1915)
}




\section{Primeiras considerações}

Durante quase quarenta anos, Ramalho Ortigão, através da Gazeta de Notícias do Rio de Janeiro, manteve com o Brasil um dos mais férteis e vantajosos intercâmbios culturais de que se tem notícia no país. Os artigos firmados por ele e publicados pelo jornal brasileiro durante este período superam a casa das cinco centenas, com um bom número deles ainda inéditos em livro.

O primeiro texto foi publicado pela Gazeta de Notícias no dia 12 de julho de 1877 e o último no dia 17 de outubro de 1915, vinte dias após a morte do escritor, em meio às homenagens a ele prestadas pelo jornal. $E$ nestes quase quarenta anos de colaboração, a mais prolongada ausência ocorreu entre 1896 e 1900, quando nada se publicou firmado pelo escritor. Dentre o volume total das colaborações, o maior número foi publicado até 1886, contando esta primeira fase com uma representação superior a $75 \%$ dos textos enviados.

Para se ter uma idéia da quantidade de "Cartas Portuguesas" enviadas ao diário brasileiro, durante este período, tenha-se em conta o que ocorreu nos anos de 1882, 1883, 1884, 1885, 1886, em que foram registradas respectivamente $41,44,48,57,52$ colaborações $^{394}$. Isto é tanto mais surpreendente quando se sabe que o livro Notas de viagem não reúne mais de 24 colaborações, de onde se deduzir que, relativamente, Ramalho Ortigão enviou à Gazeta de Notícias um número de colaborações equivalente a dois volumes como as Notas de viagem, só no ano de 1884 e, seguindo o mesmo raciocínio, o equivalente a 10 volumes, durante os cinco anos. Trata-se de uma admirável média de dois livros por ano enviados aos leitores brasileiros.

O espaço ocupado pelas "Cartas Portuguesas" na Gazeta de Notícias foi, a princípio, o rodapé da primeira página, aquele mesmo espaço destinado aos folhetins. Porém, a partir do dia 6 de novembro de 1882, elas, assim como as "Cartas de Paris", enviadas por Guilherme de Azevedo,

\footnotetext{
${ }^{394}$ Cf. quadro das colaborações.
} 
passaram a ser distribuídas pelas colunas da primeira e segunda página, ocupando, na maioria das vezes, as duas últimas colunas da primeira página e a primeira da segunda, donde inscrevê-las com os números 7,8 (correspondentes às duas últimas colunas da página) e 1 (correspondente à primeira coluna da página seguinte). Aquelas mais longas que ocupavam, além dessas, uma segunda coluna da página subseqüente, são representadas pelos números 7,8,1,2. As mais curtas que necessitavam apenas duas colunas são, evidentemente, representadas pelos algarismos 7,8. Raramente fugiam a este esquema de publicação.

A grande maioria dos textos enviados por Ramalho Ortigão, foi publicado pela Gazeta de Notícias na seção denominada "Cartas Portuguesas", representadas pela sigla "CP" no quadro das colaborações. As principais exceções seriam aquelas que tiveram por tema a Exposição Universal de Paris, de 1878, e as que se referiram à viagem do escritor por terras da Holanda, em 1883, cuja seção recebeu um novo título: "Notas de viagem". São as "NV" do quadro. Houve ainda o caso de um pequeno número de textos publicados em seções denominadas "Páginas Imperfeitas", "Jornal de um Lisboeta", "Impressões" e "Impressões Portuguesas", representadas no quadro pelas siglas "PI", “JL", "IM", "IP”, ou mesmo o caso de publicação sem qualquer referência à seção no jornal.

Algumas vezes o desenvolvimento de um tema extrapolava o espaço reservado na paginação do jornal para a publicação em determinado dia, sendo então subdividido o texto que se distribuía por mais de uma edição. Era ele assim apresentado aos leitores em uma série seqüencial de cartas que podiam ou não ser publicadas em dias imediatamente subseqüentes. Um bom exemplo são os comentários ao casamento do príncipe real D. Carlos, desdobrado em nove textos que se publicaram de 10 a 28 de junho de 1886 . Em contrapartida existem cartas abordando mais de um assunto.

Por fim, vale ainda a pena ressaltar que nem todo texto firmado por Ramalho Ortigão e publicado pela Gazeta de Notícias foi originalmente escrito para ela, constituindo-se, muitas vezes, em reproduções e aproveitamento de matérias publicadas na imprensa portuguesa. 
Como já foi observado na primeira parte desta tese, quando Ramalho Ortigão ingressou no quadro de correspondentes da Gazeta de Notícias era já um escritor formado, senhor de seu próprio estilo, desenvolvido ao longo de vinte anos de carreira. Seu nome infundia respeito e admiração e este seu estilo há muito que vinha fazendo escola. Mais de trinta fascículos de As farpas já haviam circulado por terras de Portugal quando a 2 de agosto de 1875 a Gazeta de Notícias foi fundada. Mas a quem é dado conhecer o seu trabalho neste jornal sabe muito bem o quanto o diário brasileiro foi determinante em seu encaminhamento; afinal, outro agora era seu público.

E é a este público novo, transatlântico, que ele, viajante obstinado e observador curioso, descreve paisagens da França, da Holanda, da Itália, da Suíça e, como não poderia deixar de ser, também de seu país. Palmilhador de estradas, viaja as províncias de Portugal, particularmente o Minho, que minhoto nunca deixou de ser. Percorre as estradas desta sua província em carruagens, em lombos de burro ou mesmo a pé, como um literato feito em andarilho. $E$ durante quase quarenta anos, revela seu país aos brasileiros, descobrindo e descrevendo a paisagem e o povo, desde as cidades mais notórias até os cantões mais esquecidos, sem jamais deixar de lado, no entanto, seu velho público português. Veja-se, por exemplo, o que ocorre com os artigos recolhidos no primeiro volume, subintitulado "A vida provincial", da segunda edição de As farpas, realizada por David Corazzi em 1887, dos quais somente um não foi publicado pelo jornal brasileiro. São, em sua esmagadora maioria, textos escritos depois de 1882, ano em que foram publicados os três últimos folhetos da edição primeira de As farpas. Trata-se, portanto, de matéria produzida originalmente para a Gazeta de Notícias. De 1884 são descrições das praias de São João da Foz, de Espinho e da Granja ${ }^{395}$; de 1885 são paisagens de entre Douro e Minho, do vale de Jugueiros, das margens do

\footnotetext{
${ }^{395}$ Foi chegado desta praia ao Porto que Eça de Queirós se juntou para um almoço no Palácio de Cristal com os mesmos amigos que pousaram para o famoso retrato do "Grupo dos cinco".
} 
Lima; de 1886 aspectos do Ribatejo, da Estremadura, das Caldas da Rainha, da Vila de Óbidos e de Alcobaça. E a mesma coisa se dá com outras obras do autor.

No princípio de sua colaboração, Ramalho se achou dividido entre o cronista e o repórter, alternando matérias de caráter opinativo com outras de caráter informativo. Porém a partir do segundo semestre de 1882, um correspondente noticioso, responsável pela informação, foi contratado pela Gazeta e a ele coube quase que exclusivamente o papel de cronista dos acontecimentos. Vale lembrar que, para a direção do jornal, havia que se distinguir, até na forma, uma carta noticiosa de uma crônica, ou folhetim: "que é sempre uma obra literária"396.

E era exatamente isto o que ele havia feito em $O$ Jornal do Porto e vinha fazendo em As farpas: vários recortes da realidade, formando um mosaico, um painel que, a despeito da mão do artista aqui e ali enriquecendo a matéria, iam-se sempre escrevendo, como dizia Eça de Queirós, "o verdadeiro romance realista" ${ }^{397}$. A realidade e tudo o que ela compreendia era a sua matéria - a natureza, o mundo visível, os reinos, vegetal, mineral, animal e dentro deste o homem em sociedade. Refletindo em seu trabalho os valores comuns aos homens do século XIX, principalmente no que diz respeito à honra e à moral, a sua obra é um espelho de sua sociedade. E isto fica evidente em suas colaborações para a Gazeta de Notícias.

Considerado o próprio "papa-defunto" da crônica portuguesa, Ramalho não deixava passar em branco o falecimento das personalidades destacadas de seu tempo. Entre os vários necrológios escritos para Gazeta de Notícias se destacam os de Caldas Aulete, do duque de Ávila e Bolama e o de Cruz Coutinho, o livreiro fundador de $O$ Jornal do Porto, - este último, não tanto pela importância do morto quanto pela beleza do texto. Crônica de saudades, lembrando com bonomia o proprietário do jornal em que principiou a carreira, foi publicada no diário brasileiro nos dias 28 e 29 de junho de 1885 .

\footnotetext{
${ }^{396}$ De uma carta enviada em 23 de setembro de 1882 por Henrique Chaves a Mariano Pina, que substituía Guilherme de Azevedo na correspondência de Paris. (Elza Mine, Páginas Flutuantes, p. 200).

${ }^{397}$ Eça de Queirós, Cartas, p. 20.
} 
Admirador exaltado de revolucionários, homens de ação ou bem nascidos, desapegados da vida e da fortuna, o necrológio de Jerônimo Colaço de Magalhães, o dandy que esbanjou toda a legítima paterna em Paris, vivendo a vida parisiense, é uma das belas páginas de Ramalho Ortigão. No perfil deste grande elegante, traçado pelo escritor, e no prefácio de $A$ correspondência de Fradique Mendes de Eça de Queirós, Câmara Reis viu "curiosos pontos de contato" ${ }^{398}$. Publicado nos dias 23 e 25 de fevereiro e 1 de março de 1884, foi, como o de Cruz Coutinho recolhido posteriormente no terceiro volume da segunda edição de As farpas, aquela de 1887.

Sente-se a falta do necrológio de Eça de Queirós, o que se vê justificado por se dar o falecimento do amigo quando Ramalho se encontrava em viagem pela Itália. Mas não deixou de consignar o fato em carta ao genro Eduardo Burnay, autorizando a sua publicação, o que se deu no Jornal do Comércio, de Lisboa, a 30 de agosto de 1900.

Meticuloso, ponderado e corajoso, não se furtava aos assuntos considerados delicados, não temia criticar ocupantes do alto escalão do poder, expondo seus pontos de vista sem medo das conseqüências, mesmo que isso resultasse em duelo a floretes ${ }^{399}$. Para ele a polêmica jornalística era um prato de arroz-doce. Camilo foi seu mestre, o admirado mestre que nunca deixou de louvar.

Amante de seu país e militante da crítica, Ramalho se acha entre aqueles que mais condenaram a monarquia constitucional portuguesa. Deplorava o rotativismo de poder, o parlamentarismo, o votismo e o compadrio que a seu ver só faziam corromper e desacreditar o sistema político. Porém, da mesma forma como desconfiava do governo, confiava no seu povo, enaltecendo sempre a sua capacidade de trabalho, a sua força de vontade, a sua voluntariedade, a sua disposição e criatividade para enfrentar a vida e resistir, sombranceiramente, às adversidades, buscando sempre encontrar, independentemente de governos, os seus próprios caminhos e meios de vida.

\footnotetext{
${ }^{398}$ Câmara reis, As questões morais e sociais na literatura portuguesa: Ramalho Ortigão, p. 190.

${ }^{399}$ Foi o que se deu com Antero de Quental, que se considerou ofendido em sua honra pelo opúsculo Literatura de hoje, com o qual Ramalho entrou na polêmica "Do bom senso e do bom gosto".
} 
Bem poucos foram aqueles que trataram tanto das coisas de Portugal quanto Ramalho Ortigão. Há mesmo quem julgue não ser nenhum exagero considerar a sua obra a própria sociedade portuguesa passada a limpo. E se isto for verdade, para tanto muito contribuíram a Gazeta de Notícias e a seção "Cartas Portuguesas", marca registrada desse escritor que, ao longo de quase quarenta anos, viveu uma perfeita simbiose com 0 jornalismo brasileiro. 


\section{1 - Convenções estabelecidas para o registro das corrências de matérias assinadas pelo escritor.}

Para identificação das diferentes contribuições de Ramalho Ortigão publicadas pela Gazeta de Notícias foram observadas as seguintes convenções:

ANO: Ano de publicação na Gazeta de Notícas, a partir de sua fundação.

NUM: Número do jornal, relativamente ao ano de publicação.

DAT P: Data de publicação da carta na Gazeta de Notícias: dia da semana, dia do mês, mês e ano (ex. Qua 020178 = Quartafeira, 2 de janeiro de 1878).

PAG: Página do jornal em que a colaboração vem publicada.

COL: Colunas do jornal ocupadas pela matéria.

1/8: colunas 1 a 8. São as cartas publicadas no espaço do folhetim. A única exceção é a que foi publicada no dia 11 de março de 1908, sobre o assassinato do rei D. Carlos, que ocupou todas as colunas da primeira página.

781: cada algarismo corresponde a um número de coluna. $\mathrm{O}$ decréscimo na seqüência que vinha crescente indica mudança de página ( ex: 7812 = sétima e oitava colunas de uma página e primeira e segunda da página seguinte)

S: $\quad$ Título da seção do jornal sob o qual vem publicada a carta.

CP: Cartas Portuguesas

NV: Notas de viagem

IP: Impressões Portuguesas
JL: Jornal de um Lisboeta

IM: Impressões

DAT E: Data de envio da carta.

LOC E: Local de onde é remetida a colaboração.

TÍTULO OU ASSUNTO: Título ou assunto da carta.

Os asteriscos que aparecem ao final das linhas indicam artigos não encontrados em coletâneas do autor. 
2 - Quadro geral das colaborações de

Ramalho Ortigão publicadas pela Gazeta de Notícias

\begin{tabular}{|c|c|c|c|c|c|c|c|c|c|c|}
\hline ANO & NUM & DAT $\mathbf{P}$ & PAG & COL & $\mathbf{S}$ & DAT E & LOC E & TÍTULO OU ASSUNTO & PALAVRAS INICIAIS & \\
\hline 3 & 191 & Qui 120777 & 1 & $1 / 8$ & $\mathrm{CP}$ & 1306 & Lisboa & Carta sobre vários assuntos & $\begin{array}{l}\text { No domingo último houve em Lisboa dois espetáculos públicos: } \\
\text { uma conferência literária e uma }\end{array}$ & * \\
\hline 3 & 205 & Qui 260777 & 1 & $1 / 8$ & $C P$ & 300677 & Lisboa & 0 arrendamento do passeio público & $\begin{array}{l}\text { Na noite de } 17 \text { do corrente, o Passeio Público de Lisboa foi } \\
\text { teatro de um dos mais extraordinários }\end{array}$ & * \\
\hline 3 & 217 & Ter 070877 & 1 & $1 / 8$ & $\mathrm{CP}$ & 1207 & Lisboa & Carta sobre vários assuntos & $\begin{array}{l}\text { A bordo do vapor Zaire saíram a barra de Lisboa os dois } \\
\text { exploradores portugueses que vão a Luanda }\end{array}$ & * \\
\hline 3 & 238 & Ter 280877 & 1 & $1 / 8$ & CP & 2807 & Lisboa & Carta sobre vários assuntos & $\begin{array}{l}0 \text { aniversário da entrada das tropas liberais em Lisboa, sob o } \\
\text { comando do Duque da Terceira }\end{array}$ & * \\
\hline 3 & 253 & Qui 130977 & 1 & $1 / 8$ & CP & 160877 & Lisboa & A vilegiatura e a questão do duelo & $\begin{array}{l}\text { Começou a vilegiatura lisbonense. }{ }^{1}{ }^{1} \text { sua majestade el-rei } \\
\text { partiu para Vidago onde está }\end{array}$ & * \\
\hline 3 & 265 & Ter 250977 & 1 & $1 / 8$ & CP & 2808 & Lisboa & Chegada a Lisboa de D.Pedro I & $\begin{array}{l}\text { Sua majestade o imperador do Brasil chegou no dia } 24 \text { a esta } \\
\text { cidade, revestido da simplicidade }\end{array}$ & * \\
\hline 3 & 275 & Sex 051077 & 1 & $1 / 8$ & CP & 1809 & Lisboa & A morte de Alexandre Herculano & $\begin{array}{l}\text { A hora a que escrevo estas linhas, está em iminente perigo de } \\
\text { vida o insigne escritor Alexandre }\end{array}$ & * \\
\hline 3 & 313 & Seg 121177 & 1 & $1 / 8$ & $\mathrm{CP}$ & $S / d$ & & A tradução do Hamlet por D. Luís & $\begin{array}{l}\text { Indiquei na minha última carta que o novo astro recentemente } \\
\text { despontado no firmamento da literatura }\end{array}$ & * \\
\hline 3 & 321 & Ter 201177 & 1 & $1 / 8$ & CP & 281077 & Lisboa & Questão de honra e questão clerical & $\begin{array}{l}0 \text { período a que esta carta se refere foi de tal modo fértil } \\
\text { em escândalos de diferentes naturezas }\end{array}$ & * \\
\hline 3 & 336 & Qua 051277 & 1 & $1 / 8$ & $\mathrm{CP}$ & 1211 & Porto & Inauguração da ponte sobre o Douro & $\begin{array}{l}\text { A festa de inauguração da ponte sobre o Douro, à qual acabo } \\
\text { de vir assistir, é o fato mais }\end{array}$ & * \\
\hline 3 & 349 & Ter 181277 & 1 & $1 / 8$ & & 2811 & Lisboa & A África portuguesa & $\begin{array}{l}\text { Está anunciada para amanhã, às } 8 \text { horas da noite, a terceira } \\
\text { das conferências públicas promovidas }\end{array}$ & \\
\hline- & - & - & - & - & - & - & - & - & - & - \\
\hline 4 & 002 & Qua 020178 & 1 & $1 / 8$ & $\mathrm{CP}$ & 1012 & Lisboa & Celebração do $1^{\circ}$ de Dezembro & $\begin{array}{l}\text { O dia } 1^{\circ} \text { deste mês foi apenas celebrado com o competente } T e \\
\text { Deum na igreja da Sé e com alguns }\end{array}$ & * \\
\hline 4 & 019 & Sab 190178 & 1 & $1 / 8$ & CP & 2512 & Lisboa & 0 natal minhoto & $\begin{array}{l}\text { É o dia de Natal. [A cidade amanheceu contente e alegre no } \\
\text { céu fresco e azul. }\end{array}$ & \\
\hline 4 & 032 & Sex 010278 & 1 & $1 / 8$ & $\mathrm{CP}$ & S/d & & S. Majestade o senhor D. Luís & $\begin{array}{l}\text { A monarquia - esta instituição tão tão perigosa, que bastou } \\
\text { ela só, nas mão de um Carlos IV }\end{array}$ & \\
\hline 4 & 033 & Sab 020278 & 1 & $1 / 8$ & $\mathrm{CP}$ & 0601 & Lisboa & 0 ano novo e o ano velho & $\begin{array}{l}\text { Na estrada real do tempo, nesta esquina do século XIX em que } \\
\text { nos achamos, acaba de }\end{array}$ & * \\
\hline 4 & 038 & Qua 070278 & 1 & $1 / 8$ & $\mathrm{CP}$ & 1501 & Lisboa & Necrológios & $\begin{array}{l}\text { Escrevo esta linhas no meio de túmulos recentemente abertos. } \\
\text { A crônica de Lisboa é hoje uma }\end{array}$ & * \\
\hline 4 & 062 & Dom 030378 & 3 & $1 / 8$ & & $s / d$ & & As farpas & $\begin{array}{l}\text { Resposta do senhor Ramalho Ortigão à senhora portuguesa. } \\
\text { [Asseguram-nos que o folhetim assinado por Irmã de Caridade }\end{array}$ & \\
\hline 4 & 067 & Sab 090378 & 1 & $1 / 8$ & CP & 2701 & Lisboa & Votação na Câmara dos deputados & $\begin{array}{l}\text { A câmara dos deputados resolveu ontem por } 69 \text { votos contra } 19 \\
\text { que o governo não merecia a confiança }\end{array}$ & * \\
\hline 4 & 075 & Seg 180378 & 1 & $1 / 8$ & CP & 1702 & Lisboa & Política portuguesa e morte de Pio IX & $\begin{array}{l}\text { Onde está o gato? Onde está a dama? onde está a lebre? Onde } \\
\text { está o cão? Tais são as perguntas }\end{array}$ & * \\
\hline 4 & 082 & Seg 250378 & 1 & $1 / 8$ & $\mathrm{CP}$ & 2202 & Lisboa & Resenha do livro o primo Basílio & $\begin{array}{l}\text { Foi ontem posto a venda em Lisboa, o primo Basílio (episódio } \\
\text { doméstico), novo romance de Eça }\end{array}$ & * \\
\hline 4 & 090 & Ter 020478 & 1 & $1 / 8$ & $\mathrm{CP}$ & 1802 & Lisboa & 0 carnaval em Lisboa & $\begin{array}{l}\text { Temos o carnaval. A grande novidade nas festas deste ano são } \\
\text { os bailes no teatro de são carlos }\end{array}$ & * \\
\hline 4 & 107 & Sex 190478 & 1 & $1 / 8$ & $\mathrm{CP}$ & 2403 & Lisboa & Juramento político do príncipe real & $\begin{array}{l}\text { Sua Alteza o Príncipe Real acaba de prestar perante as cortes } \\
\text { gerais o seu juramento político }\end{array}$ & * \\
\hline 4 & 118 & Ter 300478 & 1 & $1 / 8$ & $\mathrm{CP}$ & 2603 & Lisboa & As correntes literárias & $\begin{array}{l}\text { Sua Alteza o Príncipe Real acaba de prestar perante as cortes } \\
\text { gerais o seu juramento político }\end{array}$ & * \\
\hline 4 & 124 & Ter 070578 & 1 & $1 / 8$ & CP & 1304 & Lisboa & As correntes literárias II & $\begin{array}{l}\text { Referi-me na minha precedente carta aos } \\
\text { recentemente criados. É preciso que complete }\end{array}$ & \\
\hline
\end{tabular}

${ }_{1}$ [ sinal indicativo de abertura de novo parágrafo.

Colaborações não encontradas em livros do autor são analisadas com asterisco (última coluna) 


\begin{tabular}{|c|c|c|c|c|c|c|c|c|c|c|}
\hline ANO & NUM & DAT $\mathbf{P}$ & PAG & COL & $\mathbf{S}$ & DAT E & LOC E & TÍTULO OU ASSUNTO & PALAVRAS INICIAIS & \\
\hline 4 & 131 & Ter 140578 & 1 & $1 / 8$ & $\mathrm{CP}$ & 2204 & Lisboa & 0 julgamento de Joana Pereira & $\begin{array}{l}0 \text { julgamento de Joana Pereira é um dos sucessos que mais tem } \\
\text { excittado a curiosidade da população }\end{array}$ & * \\
\hline 4 & 138 & Ter 210578 & 1 & $1 / 8$ & $\mathrm{CP}$ & 2804 & Lisboa & Festas da Semana Santa & $\begin{array}{l}\text { Decorreram com a solenidade ordinária as festas da semana } \\
\text { santa. Os jornais publicaram por esta }\end{array}$ & * \\
\hline 4 & 145 & Ter 280578 & 1 & $1 / 8$ & $\mathrm{CP}$ & 0805 & Lisboa & Encerramento da sessão legislativa & $\begin{array}{l}\text { Acaba de encerrar-se a sessão legislativa. [Expirou o prazo } \\
\text { do mandato aos ilustres representantes }\end{array}$ & * \\
\hline 4 & 153 & Qua 050678 & 1 & $1 / 8$ & $\mathrm{CP}$ & 1305 & Lisboa & Viajantes célebres em Lisboa & $\begin{array}{l}\text { Acham-se atualmente em Lisboa vários viajantes célebres. [Um } \\
\text { deles é o Sr. Aurbertin, autor de uma }\end{array}$ & * \\
\hline 4 & 159 & Ter 110678 & 1 & $1 / 8$ & $\mathrm{CP}$ & 2105 & Lisboa & Despachos do ministro Sr. Borjona & $\begin{array}{l}\text { Dois despachos ultimamente feitos pelo Sr. Borjona, ministro } \\
\text { dos negócios eclesiásticos e da }\end{array}$ & * \\
\hline 4 & 170 & Sab 220678 & 1 & $1 / 8$ & $\mathrm{CP}$ & 0106 & Lisboa & Carta sobre vários assuntos & $\begin{array}{l}\text { Acha-se preso na cadeia do Limoeiro como fabricante } \\
\text { passador de notas falsas do banco de }\end{array}$ & * \\
\hline 4 & 173 & Ter 250678 & 1 & $1 / 8$ & $\mathrm{CP}$ & 3005 & Lisboa & A morte de Caldas Aulete & $\begin{array}{l}\text { A ala dos antigos discípulos de Garret e de Herculano acaba } \\
\text { de rarear com mais uma lacuna pela }\end{array}$ & \\
\hline 4 & 187 & Ter 090778 & 1 & $1 / 8$ & CP & 1306 & Lisboa & Visita a uma escola infantil & $\begin{array}{l}\text { Acabo de visitar com o mais legítimo prazer a melhor escola } \\
\text { de crianças que tenho visto em Portugal }\end{array}$ & * \\
\hline 4 & 191 & Sab 130778 & 1 & $1 / 8$ & $\mathrm{CP}$ & 2306 & Lisboa & Solenidade no Porto & $\begin{array}{l}\text { A cidade do Porto acaba de celebrar a mais importante } \\
\text { solenidade que um povo pode registrar nos }\end{array}$ & * \\
\hline 4 & 226 & Sab 170878 & 1 & $1 / 8$ & NV & 1807 & Paris & As mulheres de Paris & $\begin{array}{l}\text { Entre o Paris de hoje e o Paris de há nove anos, entre o } \\
\text { Paris da República e o Paris do Segundo }\end{array}$ & \\
\hline 4 & 230 & Qua 210878 & 1 & $1 / 8$ & NV & 2107 & Paris & Apresentação do senhor Pertuiset & $\begin{array}{l}\text { Minha senhoras e meus senhores! Peço licença para apresentar- } \\
\text { lhes o meu amigo o senhor Pertuiset }\end{array}$ & \\
\hline 4 & 238 & Qua 290878 & 1 & $1 / 8$ & NV & $s / d$ & & Alguns sucessos & $\begin{array}{l}\text { Principiarei pelo mais triste. Acabo de } \text { acompanhar ao } \\
\text { cemitério de Montmartre o cadáver de Antônio }\end{array}$ & \\
\hline 4 & 243 & Ter 030978 & 1 & $1 / 8$ & NV & 2607 & Paris & Visita a estabelecimentos & $\begin{array}{l}\text { Falemos de alguns estabelecimentos. [Visitei a Sorbonne, o } \\
\text { colégio de França e a Escola de Medicina. }\end{array}$ & \\
\hline 4 & 250 & Ter 100978 & 1 & $1 / 8$ & NV & 3007 & Paris & D. Pedro II e Victor Hugo & $\begin{array}{l}\text { Deve aparecer ao público, na semana próxima, um novo livro } \\
\text { intitulado - Victor Hugo chez lui. }\end{array}$ & \\
\hline 4 & 254 & Sab 140978 & 1 & $1 / 8$ & NV & 1008 & Paris & 0 Congresso das Mulheres & $\begin{array}{l}\text { De tantos congressos ultimamente reunidos em Paris nenhum } \\
\text { parecia mais destinado a atrair tão }\end{array}$ & \\
\hline 4 & 257 & Ter 170978 & 1 & $1 / 8$ & NV & 1308 & Paris & A sociedade e a literatura em Paris & $\begin{array}{l}\text { Madame de Girardin dizia não Ter dúvida em admitir que um } \\
\text { homem bem educado se embriagasse, mas }\end{array}$ & \\
\hline 4 & 260 & Sex 200978 & 1 & $1 / 8$ & NV & 1808 & Paris & 0 Palácio do Trocadéro & $\begin{array}{l}\text { Quem entra na exposição pela porta do Trocadéro, vasto } \\
\text { palácio em hemiciclo com perto de meio }\end{array}$ & \\
\hline 4 & 266 & Qui 260978 & 1 & $1 / 8$ & NV & s/d & & A exposição & $\begin{array}{l}\text { Antes de entrarmos no Palácio do Trocadéro, ou no do Campo de } \\
\text { Marte, lancemos a vista a alguns dos }\end{array}$ & \\
\hline 4 & 282 & Sab 121078 & 1 & $1 / 8$ & NV & $s / d$ & & A exposição de pinturas & $\begin{array}{l}\text { No Campo de Marte, no Palácio da Indústria, e na galeria da } \\
\text { Rua Lepelletier, a pintura francesa }\end{array}$ & \\
\hline 4 & 295 & Sex 251078 & 1 & $1 / 8$ & NV & $s / d$ & & A exposição de pinturas (cont.) & $\begin{array}{l}\text { Entre os vários artistas "cabanelizados" na massa do sangue } \\
\text { pela influências do Instituto, da }\end{array}$ & \\
\hline 4 & 317 & Sab 161178 & 1 & $1 / 8$ & NV & $\mathrm{s} / \mathrm{d}$ & & os impressionistas & $\begin{array}{l}\text { Seriam extremamente incompletas as notas em } \\
\text { procurado dar uma idéia do estado presente }\end{array}$ & \\
\hline 4 & 324 & Sab 231178 & 1 & $1 / 8$ & NV & $S / d$ & & As nações artísticas & $\begin{array}{l}\text { Depois da França, os países que merecem a atenção na história } \\
\text { da arte contemporânea são a }\end{array}$ & \\
\hline 4 & 326 & Seg 251178 & 1 & $1 / 8$ & NV & $s / d$ & & As nações artísticas (cont.) & $\begin{array}{l}\text { Depois da França, os países que merecem a atenção na história } \\
\text { da arte contemporânea são as }\end{array}$ & \\
\hline 4 & 328 & Qua 271178 & 1 & $1 / 8$ & NV & $s / d$ & & As nações artísticas (concl.) & $\begin{array}{l}\text { Na Alemanha desapareceram completamente os vestígios das } \\
\text { antigas escolas da Baixa-Saxônia, de }\end{array}$ & \\
\hline 4 & 338 & Sab 071278 & 1 & $1 / 8$ & NV & $s / d$ & & A mobília nos países expositores & $\begin{array}{l}\text { Basta percorrer as vastas e suntuosas galerias ocupadas no } \\
\text { Palácio de Marte pelas mobílias, pelos }\end{array}$ & \\
\hline 4 & 345 & Dom 151278 & 1 & $1 / 8$ & NV & $S / d$ & & A mobília futura & $\begin{array}{l}\text { A casa da família moderna não pode continuar a ser, como até } \\
\text { aqui, a casa romântica. [0 luxo dos }\end{array}$ & \\
\hline 4 & 349 & Qui 191278 & 1 & $1 / 8$ & NV & $\mathrm{s} / \mathrm{d}$ & & 0 ensino & $\begin{array}{l}\text { O segundo grupo da Exposição Universal, consagrado à educação } \\
\text { e ao ensino, é de tal modo }\end{array}$ & \\
\hline- & - & - & - & - & - & - & - & - & - & - \\
\hline
\end{tabular}




\begin{tabular}{|c|c|c|c|c|c|c|c|c|c|c|}
\hline ANO & NUM & DAT $P$ & PAG & COL & $\mathbf{S}$ & DAT E & LOC E & TÍTULO OU ASSUNTO & PALAVRAS INICIAIS & \\
\hline 5 & 003 & Sex 030179 & 1 & $1 / 8$ & NV & $s / d$ & & 0 museu pedagógico & $\begin{array}{l}\text { A intervenção do estado na instrução pública dá sempre em } \\
\text { resultado ensinar unicamente aos cidadãos }\end{array}$ & \\
\hline 5 & 003 & Sex 030179 & 2 & $1 / 8$ & NV & $s / d$ & & Kinder-Garden & $\begin{array}{l}\text { Em uma das conferências celebradas no palácio do Trocadéro, } \\
\text { o senhor Quatrefages, que presidia a reunião, apresentou }\end{array}$ & \\
\hline 5 & 010 & Sex 100179 & 1 & $1 / 8$ & NV & $\mathrm{s} / \mathrm{d}$ & & Através dos congressos & $\begin{array}{l}\text { As academias, pelo seu princípio electivo que lhes dá o } \\
\text { direito de exclusão, e pela sua organização }\end{array}$ & \\
\hline 5 & 012 & Dom 120179 & 1 & $1 / 8$ & NV & $s / d$ & & Através dos congressos & $\begin{array}{|lrlll|}\text { As questões das regas, discutidas no } & \text { congresso } & \text { de } \\
\text { engenharia, é de uma importância cada vez } \mathrm{m} & & \\
\end{array}$ & \\
\hline 5 & 036 & Qua 050279 & 1 & $1 / 8$ & NV & $s / d$ & & A antropologia na exposição & $\begin{array}{l}\text { Ao sair do palácio do Campo de Marte guarda-se por muito } \\
\text { tempo no espírito uma impressão de }\end{array}$ & \\
\hline 5 & 045 & Sex 140279 & 1 & $1 / 8$ & NV & $s / d$ & & A antropologia na exposição & $\begin{array}{l}\text { A exposição de Antropologia poderia dividir-se em cinco } \\
\text { seções principais: a arqueologia }\end{array}$ & \\
\hline 5 & 065 & Sex 070379 & 1 & $1 / 8$ & $\mathrm{CP}$ & 1302 & Lisboa & Concurso de pintura & $\begin{array}{l}\text { Abriu-se a dois dias, em uma das salas da Academia de Belas } \\
\text { Artes, a exposição dos quadros feitos }\end{array}$ & \\
\hline 5 & 073 & Sab 150379 & 1 & $1 / 8$ & $\mathrm{CP}$ & 2901 & Lisboa & Jerônimos e Viagem à roda da Parv. & $\begin{array}{l}\text { Durante a minha ausência desta folha, como cronista de } \\
\text { Lisboa, caiu a Torre do Jerônimos em Belém }\end{array}$ & \\
\hline 5 & 078 & Qui 200379 & 1 & $1 / 8$ & $\mathrm{CP}$ & 0502 & Lisboa & Baile no paço da Ajuda & $\begin{array}{l}\text { 0 Paço da Ajuda abriu as suas salas para o primeiro baile do } \\
\text { presente inverno, e leu no Diário de }\end{array}$ & * \\
\hline 5 & 086 & Sex 280379 & 1 & $1 / 8$ & CP & 2702 & Lisboa & Proibição do jogo do entrudo & $\begin{array}{l}\text { O atual governador civil de Lisboa, senhor D. Luís da Câmara } \\
\text { Leme, descarregou o último golpe no }\end{array}$ & * \\
\hline 5 & 092 & Qui 030479 & 1 & $1 / 8$ & $\mathrm{CP}$ & 1303 & Lisboa & Discurso de Rodrigues de Freitas & $\begin{array}{l}\text { 0 senhor Rodrigues de Freitas, deputado republicano, } \\
\text { proferiu no parlamento um discurso que pelas }\end{array}$ & * \\
\hline 5 & 102 & Dom 130479 & 1 & $1 / 8$ & CP & 1803 & Lisboa & Tosão de Ouro a Fontes Pereira & $\begin{array}{l}\text { A cerimônia da investidura da ordem do Tosão de Ouro ao } \\
\text { senhor Fontes Pereira de Melo foi um }\end{array}$ & \\
\hline 5 & 120 & Sex 020579 & 1 & $1 / 8$ & $\mathrm{CP}$ & 2803 & Lisboa & Carta sobre vários assuntos & $\begin{array}{l}\text { A companhia do teatro de São Carlos }(\ldots) \text { fazer ouvir a missa } \\
\text { de Réquiem de verdi. }\end{array}$ & * \\
\hline 5 & 127 & Sex 090579 & 1 & $1 / 8$ & $\mathrm{CP}$ & 1304 & Lisboa & A reforma ortográfica & $\begin{array}{l}\text { Na Academia das Ciências começou, como eu lhes anunciei, na } \\
\text { quinta-feira passada, a discussão }\end{array}$ & * \\
\hline 5 & 132 & Qui 150579 & 1 & $1 / 8$ & CP & 2004 & Lisboa & A enfermidade da rainha & $\begin{array}{l}\text { Sua Majestade a rainha adoeceu há dias com um pleuriz duplo. } \\
\text { A notícia do fato consternou Lisboa }\end{array}$ & * \\
\hline 5 & 144 & Seg 260579 & 1 & $1 / 8$ & $\mathrm{CP}$ & 2604 & Lisboa & 0 penteeiro da Rua da Almada & $\begin{array}{l}\text { Costumam fabricar os penteeiros lisbonenses um engenhoso } \\
\text { instrumento composto de uma pequena mão }\end{array}$ & \\
\hline 5 & 159 & Qui 120679 & 1 & $1 / 8$ & $\mathrm{CP}$ & 1905 & Lisboa & Espetáculo amador para caridade & $\begin{array}{l}\text { Para um fim de caridade, foi ultimamente organizado no salão } \\
\text { do teatro da Trindade um espetáculo }\end{array}$ & * \\
\hline 5 & 161 & Sab 140679 & 1 & $1 / 8$ & $\mathrm{CP}$ & 2205 & Lisboa & Os noivos, de Teixeira de Queiroz & $\begin{array}{l}\text { Os costumes domésticos da burguesia de Lisboa acaba de } \\
\text { encontrar um novo autor no romancista }\end{array}$ & * \\
\hline 5 & 172 & Qua 250679 & 1 & $1 / 8$ & $\mathrm{CP}$ & 2805 & Lisboa & Carta sobre vários assuntos & $\begin{array}{l}\text { Depois das preces por ocasião da enfermidade de Sua } \\
\text { Majestade celebraram-se como lhes disse }\end{array}$ & * \\
\hline 5 & 175 & Sab 280679 & 1 & $1 / 8$ & CP & 3105 & Lisboa & Aspectos do verão & $\begin{array}{l}\text { Conquanto a temperatura persista com uma insistência } \\
\text { facciosa em não passar de } 16 \text { graus Réamur }\end{array}$ & \\
\hline 5 & 181 & Sex 040779 & 1 & $1 / 8$ & $\mathrm{CP}$ & 1306 & Lisboa & Visita a Lisboa de três príncipes & $\begin{array}{l}\text { Estiveram ultimamente em Lisboa não menos de três príncipes, } \\
\text { todos de sangue real. [ Apesar disso }\end{array}$ & * \\
\hline 5 & 197 & Dom 200779 & 1 & $1 / 8$ & CP & 1706 & Lisboa & Conferência de Serpa Pinto & $\begin{array}{l}\text { Assisti ontem à noite, no salão de teatro da Trindade, à } \\
\text { conferência feita pelo major Serpa Pinto }\end{array}$ & * \\
\hline 5 & 202 & Sex 250779 & 1 & $1 / 8$ & $\mathrm{CP}$ & 3006 & Lisboa & Febre amarela em Pedrouços & $\begin{array}{l}\text { A cidade foi há dias sobressaltada com esta notícia: Temos a } \\
\text { febre amarela em Pedrouços. }\end{array}$ & * \\
\hline 5 & 213 & Ter 050879 & 1 & $1 / 8$ & $\mathrm{CP}$ & 1407 & Lisboa & Celebração à saúde da rainha & $\begin{array}{l}\text { As autoridades policiais e administrativas de Lisboa tiveram } \\
\text { há três dias uma idéia original: }\end{array}$ & * \\
\hline 5 & 222 & Qui 140879 & 1 & $1 / 8$ & CP & 1807 & Lisboa & Contos populares, de Adolfo Coelho & $\begin{array}{l}\text { Adolfo Coelho, o eminente professor de filologia, acaba de } \\
\text { dar à luz um livro de erudição que }\end{array}$ & * \\
\hline 5 & 232 & Dom 240879 & 1 & $1 / 8$ & $\mathrm{CP}$ & 2107 & Lisboa & A monsenhor Pinto de Campos & $\begin{array}{l}\text { Monsenhor Pinto de Campos tem continuado a publicar no } \\
\text { Diário de Notícias interessantes cartas de }\end{array}$ & \\
\hline 5 & 236 & Qui 280879 & 1 & $1 / 8$ & $\mathrm{CP}$ & 310779 & Lisboa & Carta sobre vários assuntos & $\begin{array}{l}\text { E difícil avaliar, pelas leituras dos jornais, qual a } \\
\text { situação política do país. As folhas }\end{array}$ & \\
\hline
\end{tabular}




\begin{tabular}{|c|c|c|c|c|c|c|c|c|c|c|}
\hline ANO & NUM & DAT $P$ & PAG & COL & $\mathbf{S}$ & DAT E & LOC E & TÍTULO OU ASSUNTO & PALAVRAS INICIAIS & \\
\hline 5 & 257 & Qui 180979 & 3 & $1 / 8$ & $\mathrm{CP}$ & 120879 & Lisboa & Carta sobre vários assuntos & $\begin{array}{l}\text { Em uma das páginas da prosa tão contestada com que o senhor } \\
\text { Camilo Castelo Branco intermeia }\end{array}$ & * \\
\hline 5 & 260 & Dom 210979 & 1 & $1 / 8$ & $\mathrm{CP}$ & 170879 & Lisboa & Estação de vilegiatura & $\begin{array}{l}\text { Estamos em plena vilegiatura. Lisboa acha-se decapitada pela } \\
\text { ausência das suas celebridades }\end{array}$ & * \\
\hline 5 & 264 & Qui 250979 & 1 & $1 / 8$ & $\mathrm{CP}$ & 270879 & Lisboa & 0 paisagista Silva Porto & $\begin{array}{l}\text { Fui ultimamente em viagem de recreio à Academia de Belas } \\
\text { Artes. Ao fundo da Rua de são Francisco }\end{array}$ & \\
\hline 5 & 285 & Qui 161079 & 1 & $1 / 8$ & $\mathrm{CP}$ & 100979 & Porto & Descrição de viagem até o Porto & $\begin{array}{l}\text { A companhia de zarzuela que estava no teatro dos Recreios, } \\
\text { veio para cá no mesmo comboio em que }\end{array}$ & \\
\hline 5 & 291 & Qua 221079 & 1 & $1 / 8$ & $\mathrm{CP}$ & 1809 & Porto & A casa da Ass. Comercial do Porto & $\begin{array}{l}\text { Há cerca de quinze anos que eu fui à cCasa da Associação } \\
\text { Comercial do Porto assistir a um baile }\end{array}$ & * \\
\hline 5 & 294 & Sab 251079 & 1 & $1 / 8$ & $\mathrm{CP}$ & 2909 & S.João da Foz & Banhos e banhistas & $\begin{array}{l}\text { Às } 8 \text { da manhã abro a minha janela sobre a praia. Deliciosa } \\
\text { impressão! Um céu radioso e um vento }\end{array}$ & \\
\hline 5 & 305 & Qui 061179 & 1 & $1 / 8$ & $\mathrm{CP}$ & 3009 & Porto & Reminiscências da infância & $\begin{array}{l}\text { Um fenômeno curioso de estudar, pela importância que tem na } \\
\text { estética para a determinação do }\end{array}$ & * \\
\hline 5 & 320 & Sex 211179 & 1 & $1 / 8$ & $\mathrm{CP}$ & 1410 & Lisboa & Passeio com Elísio Mendes pelo Tejo & $\begin{array}{l}\text { Antes de ontem, Domingo, um dia magnífico, daqueles que } \\
\text { constituem o ideal de Mme de Girardin }\end{array}$ & * \\
\hline 5 & 324 & Ter 251179 & 1 & $1 / 8$ & $\mathrm{CP}$ & 2010 & Lisboa & Eleições gerais de deputados & $\begin{array}{l}\text { Fizeram-se ontem as eleições gerais de deputados, obtendo o } \\
\text { governo uma grande maioria, segundo }\end{array}$ & * \\
\hline 5 & 334 & Sex 051279 & 1 & $1 / 8$ & $\mathrm{CP}$ & 2810 & Lisboa & Cifka e as faianças artísticas & $\begin{array}{l}\text { Cifka é o nome do fabricante de algumas faianças artísticas } \\
\text { ultimamente premiadas na exposição do }\end{array}$ & \\
\hline 5 & 338 & Ter 091279 & 1 & $1 / 8$ & $\mathrm{CP}$ & 3010 & Lisboa & Resenha de 0 mestre dos namorados & $\begin{array}{l}\text { Acabo de encontrar à venda em um estanco um pequeno livro } \\
\text { com este título - o mestre dos namorados }\end{array}$ & * \\
\hline 5 & 353 & Qua 241279 & 1 & $1 / 8$ & $\mathrm{CP}$ & 1511 & Lisboa & Carta sobre vários assuntos & $\begin{array}{l}\text { Uma boa notícia: afirmam-me que a maçonaria de Lisboa pensa } \\
\text { em organizar uma liga de ensino, à }\end{array}$ & * \\
\hline$\overline{-}$ & 009 & Sex 090180 & - & $1 / 8$ & $C P$ & - & Jichoa & Conclucão da carta anterior & 0 moctro do & $\bar{*}$ \\
\hline 6 & 009 & $\operatorname{sex} 090180$ & 1 & $1 / 8$ & $\mathrm{CP}$ & 1511 & Lisboa & Conclusão da carta anterior & $\begin{array}{l}0 \text { mestre de Aviz é um medíocre bafejado pela sorte.[Tem a } \\
\text { fortuna de ter por filhos } 4 \text { dos homens }\end{array}$ & \\
\hline 6 & 016 & Sex 160180 & 1 & $1 / 8$ & $\mathrm{CP}$ & 151279 & Lisboa & Livro de poemas $O$ Hissope & $\begin{array}{l}\text { Ainda um novo livro: o Hissope, poema herói-cômico de } \\
\text { Antonio Diniz da cruz e Silva, edição de }\end{array}$ & * \\
\hline 6 & 047 & Ter 170280 & 1 & $1 / 8$ & $\mathrm{CP}$ & 200180 & Lisboa & 0 jogo e o Estado & $\begin{array}{l}\text { Há três dias Lisboa foi surpreendida por esta notícia } \\
\text { inesperada: a polícia invadira as casas de }\end{array}$ & * \\
\hline 6 & 070 & Qui 110380 & 1 & $1 / 8$ & $\mathrm{CP}$ & $S / d$ & & O livro Le Portugal à vol de oiseau & $\begin{array}{l}\text { Mme. Rattazzi é uma senhora em cujo espírito concorrem duas } \\
\text { tendências predominantes, congêneres e }\end{array}$ & * \\
\hline 6 & 112 & Sex 230480 & 1 & $1 / 8$ & $\mathrm{CP}$ & $s / d$ & & Continuação da carta anterior & $\begin{array}{l}\text { O livro de Mme. Rattazzi-Le Portugal à vol de oiseau-tem o } \\
\text { defeito fundamental das }\end{array}$ & * \\
\hline 6 & 123 & Ter 040580 & 1 & $1 / 8$ & $\mathrm{CP}$ & 2903 & Lisboa & A primeira récita do Guarani & $\begin{array}{l}\text { A } 1^{\text {a }} \text { récita do Guarani ontem, no teatro de s. Carlos, foi um } \\
\text { belo triunfo para a arte brasileira }\end{array}$ & * \\
\hline 6 & 133 & Sex 140580 & 1 & $1 / 8$ & $\mathrm{CP}$ & 1504 & Lisboa & Capello, Ivens e Nordenskiol & $\begin{array}{l}\text { Hamlet tinha a respiração curta; Lisboa tem curto o } \\
\text { entusiasmo: de sorte que Lisboa, quando admira, }\end{array}$ & * \\
\hline 6 & 139 & Qui 200580 & 1 & $1 / 8$ & $\mathrm{CP}$ & 2804 & Lisboa & o governo e o centenário de Camões & $\begin{array}{l}\text { A câmara dos dignos pares votou ontem à tarde, por } \\
\text { unanimidade e sem discussão, a lei que autoriza }\end{array}$ & \\
\hline 6 & 148 & Sab 290580 & 1 & $1 / 8$ & $\mathrm{CP}$ & 3004 & Lisboa & Os pintores da Exposição Portuguesa & $\begin{array}{l}\text { Além dos quadros de Columbano Bordalo Pinheiro, de Silva } \\
\text { Porto e dos seus discípulos Malhoa }\end{array}$ & \\
\hline 6 & 154 & Sex 040680 & 1 & $1 / 8$ & $\mathrm{CP}$ & 0805 & Lisboa & Conferência de Teófilo Braga & $\begin{array}{l}\text { A Associação do Escritores Públicos, posto que iniciada } \\
\text { apenas e não tendo de instalar-se }\end{array}$ & * \\
\hline 6 & 162 & Dom 130680 & 3 & $1 / 8$ & $\mathrm{CP}$ & 1205 & Lisboa & Um crime passional & $\begin{array}{l}\text { Estamos atravessando uma quadra lúgubre. [Dentro do breve } \\
\text { período de } 8 \text { dias houve em Lisboa duas }\end{array}$ & * \\
\hline 6 & 175 & Sex 250680 & 1 & $1 / 8$ & $\mathrm{CP}$ & 0706 & Lisboa & 0 Centenário de Camões & $\begin{array}{l}\text { Sobre a individualidade de Camões, sobre a sua influência e } \\
\text { sobre a sua obra tem-se acumulado, há }\end{array}$ & * \\
\hline 6 & 212 & Dom 010880 & 1 & $1 / 8$ & $\mathrm{CP}$ & 1207 & Lisboa & A com. de imprensa e o gov. port. & $\begin{array}{l}\text { 010880 - A estas horas sabem já os leitores, e estimo que } \\
\text { não tivessem sabido por mim - como o governo }\end{array}$ & * \\
\hline
\end{tabular}




\begin{tabular}{|c|c|c|c|c|c|c|c|c|c|c|}
\hline ANO & NUM & DAT P & PAG & COL & $\mathbf{S}$ & DAT E & LOC E & TÍTULO OU ASSUNTO & PALAVRAS INICIAIS & \\
\hline 6 & 235 & Ter 240880 & 1 & $1 / 8$ & $\mathrm{CP}$ & 2807 & Lisboa & A entrada do duque da Terceira & $\begin{array}{l}\text { 0 governo português, para o qual a festa do centenário de } \\
\text { Camões foi de caráter alheio à }\end{array}$ & * \\
\hline 6 & 244 & Qui 020980 & 1 & $1 / 8$ & $\mathrm{CP}$ & 0908 & Trafaria & Uma aldeia de pescadores & $\begin{array}{l}\text { Escrevo-lhes esta carta, em uma aldeia de pescadores, a uma } \\
\text { légua de Lisboa, na margem esquerda }\end{array}$ & * \\
\hline 6 & 249 & Ter 070980 & 1 & $1 / 8$ & $\mathrm{CP}$ & 1008 & Trafaria & A situação de abandono do lugarejo & $\begin{array}{l}\text { Descrevi-lhes ontem o que é a Trafaria no estado quase } \\
\text { selvagem em que ela se acha. o fato é }\end{array}$ & * \\
\hline 6 & 257 & Sab 180980 & 3 & $1 / 8$ & $\mathrm{CP}$ & 2008 & Trafaria & As febres em Lisboa e o descaso do gov. & $\begin{array}{l}\text { Começa a desvanecer-se em Lisboa o grande pânico produzido } \\
\text { pelas febres remitentes e tifóides, }\end{array}$ & * \\
\hline 6 & 262 & Qui 230980 & 1 & $1 / 8$ & $\mathrm{CP}$ & 2508 & Trafaria & Chegada das águas de Alviella em Lisboa & $\begin{array}{l}\text { Anunciam-se para o mês próximo dois acontecimentos da mais } \\
\text { alta importância. [Um deles é a entrada }\end{array}$ & * \\
\hline 6 & 267 & Ter 280980 & 4 & $1 / 8$ & $\mathrm{CP}$ & 0209 & Trafaria & Pescadores, mestres, cabazeiros e sonetos & $\begin{array}{l}\text { A Raposeira é uma colina que abriga a Trafaria pelo lado do } \\
\text { sul e forma a continuação e }\end{array}$ & * \\
\hline 6 & 284 & Sex 151080 & 5 & $1 / 8$ & $\mathrm{CP}$ & 2309 & Lisboa & Os congressos: antropológico e literário & $\begin{array}{l}\text { Chegaram os antropologistas e os escritores estrangeiros, e } \\
\text { estão abertos e funcionando o congresso }\end{array}$ & * \\
\hline 6 & 301 & Ter 021180 & 1 & $1 / 8$ & $\mathrm{CP}$ & 2609 & Lisboa & Os congressos & $\begin{array}{l}\text { Tem a palavra o Sr. Mortillet. Preside o Sr. Andrade Corvo, } \\
\text { tendo a sua direita o senador Henri }\end{array}$ & * \\
\hline 6 & 313 & Dom 141180 & 4 & $1 / 8$ & $\mathrm{CP}$ & 0509 & Lisboa & Os congressos & $\begin{array}{l}\text { No congresso literário discursou-se eloqüentemente sobre a } \\
\text { natureza da propriedade literária e }\end{array}$ & \\
\hline 6 & 324 & Qui 251180 & 3 & $1 / 8$ & $\mathrm{CP}$ & 2910 & Lisboa & Portugal na imprensa estrangeira & $\begin{array}{l}\text { Portugal está tendo neste momento as honras da letra redonda, } \\
\text { que há pouco tempo lhe eram }\end{array}$ & * \\
\hline 6 & 349 & Sex 171280 & 1 & $1 / 8$ & CP & 1211 & Lisboa & 0 monumento a Herculano & $\begin{array}{l}\text { Uma comissão ultimamente constituída para o fim de elevar um } \\
\text { monumento à memória de Herculano acaba }\end{array}$ & \\
\hline - & - & - & - & - & - & - & - & 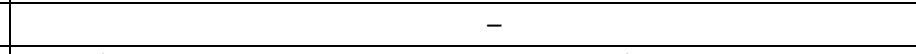 & - & - \\
\hline 7 & 006 & Qui 060181 & 1 & $1 / 8$ & $\mathrm{CP}$ & 2111 & Lisboa & 0 júri e os desfalques bancários & $\begin{array}{l}\text { Os réus do Banco Ultramarino, que o júri absolvera há dias, } \\
\text { dando o juiz tal decisão por iníqua, }\end{array}$ & * \\
\hline 7 & 012 & Qua 120181 & 1 & $1 / 8$ & $\mathrm{CP}$ & 1212 & Lisboa & Os governantes monarquistas & $\begin{array}{l}\text { Se existe o paraíso, no que é prudente não acreditar sem as } \\
\text { devidas reservas, o clima paradisíaco }\end{array}$ & * \\
\hline 7 & 035 & Sex 040281 & 1 & $1 / 8$ & $\mathrm{CP}$ & 010181 & Lisboa & Balanço da vida e do ano em Lisboa & $\begin{array}{l}\text { Não sou completamente o que se chama um triste. Pela manhã } \\
\text { cedo, pelo menos, depois de tomar uma }\end{array}$ & * \\
\hline 7 & 053 & Ter 220281 & 1 & $1 / 8$ & $\mathrm{CP}$ & 1501 & Lisboa & A recepção a J. Nabuco, em Lisboa & $\begin{array}{l}\text { Nunca estrangeiro conquistou mais rapidamente as simpatias de } \\
\text { Lisboa do que Joaquim Nabuco. A sua }\end{array}$ & * \\
\hline 7 & 058 & Dom 270281 & 1 & $1 / 8$ & $\mathrm{CP}$ & 2901 & Lisboa & Conferências na Sociedade de Geografia & $\begin{array}{l}\text { A sociedade de geografia de Lisboa tem dado nos últimos } \\
\text { tempos um espetáculo bastante brilhante de }\end{array}$ & \\
\hline 7 & 067 & Qua 090381 & 1 & $1 / 8$ & CP & 0502 & Lisboa & Almeida Garret por Gomes de Amorim & $\begin{array}{l}\text { Gomes de Amorim publicou há poucos dias o primeiro volume da } \\
\text { biografia de Almeida Garrett, }\end{array}$ & \\
\hline 7 & 080 & Qua 230381 & 1 & $1 / 8$ & $\mathrm{CP}$ & 1502 & Lisboa & As respostas ao discurso da coroa & $\begin{array}{l}\text { Depois do dia } 2 \text { de janeiro em que se abriram as cortes em que } \\
\text { el-rei proferiu o discurso da coroa, }\end{array}$ & \\
\hline 7 & 086 & Ter 290381 & 1 & $1 / 8$ & $\mathrm{CP}$ & 2402 & Lisboa & 0 discurso de Fontes Pereira de Melo & $\begin{array}{l}\text { Depois do Sr. Barros Gomes, ministro da fazenda, achava-se } \\
\text { inscrito para falar o Sr. Fontes Pereira }\end{array}$ & \\
\hline 7 & 088 & Qui 310381 & 1 & $1 / 8$ & $\mathrm{CP}$ & 1303 & Lisboa & Carlos Bento e o discurso da coroa & $\begin{array}{l}\text { 0 Sr. Carlos Bento não é inteiramente o que se chama um } \\
\text { político. Falta-lhe a dose de fé exigida, o }\end{array}$ & \\
\hline 7 & 106 & Qui 210481 & 1 & $1 / 8$ & $\mathrm{CP}$ & 2903 & Lisboa & A demissão do ministério & $\begin{array}{l}\text { O ministério chamado progressista, que há vinte e dois meses } \\
\text { dirigia os negócios do país, acaba de }\end{array}$ & * \\
\hline 7 & 123 & Dom 080581 & 1 & $1 / 8$ & CP & 3003 & Lisboa & A apresentação de Borghi Mamo, no Porto & $\begin{array}{l}\text { O nome de Borghi Mamo, a interessante cantora que fez ontem } \\
\text { no teatro s. Carlos o seu benefício de }\end{array}$ & \\
\hline 7 & 129 & Sab 140581 & 1 & $1 / 8$ & $\mathrm{CP}$ & 2204 & Lisboa & A esquadra inglesa & $\begin{array}{l}\text { O novo ministério, que deveríamos supor ter sido chamado aos } \\
\text { conselhos da coroa pelo conhecimento }\end{array}$ & * \\
\hline 7 & 137 & Dom 220581 & 1 & $1 / 8$ & $\mathrm{CP}$ & 2904 & Lisboa & Sintra, o ministério e a Semana Santa & $\begin{array}{l}\text { A grave questão política que nesse momento se debate na } \\
\text { imprensa consiste em saber se os Srs. }\end{array}$ & * \\
\hline 7 & 149 & Sab 040681 & 1 & $1 / 8$ & $\mathrm{CP}$ & 0505 & Lisboa & A morte do Duque d'Avilla e Bolama & $\begin{array}{l}\text { Foi sepultado esta tarde, no cemitério ocidental, o nobre } \\
\text { duque de Ávilla e de Bolama, falecido há }\end{array}$ & \\
\hline 7 & 189 & Sab 160781 & 1 & $1 / 8$ & & 2305 & Badajoz & 0 centenário de Calderon em Madrid II & $\begin{array}{l}\text { Almoço no buffet da estação. [ Cozinha de azeite, grande } \\
\text { profusão de tubaras }\end{array}$ & \\
\hline
\end{tabular}




\begin{tabular}{|c|c|c|c|c|c|c|c|c|c|c|}
\hline ANO & NUM & DAT $P$ & PAG & $\mathrm{COL}$ & $\mathbf{S}$ & DAT E & LOC E & TÍTULO OU ASSUNTO & PALAVRAS INICIAIS & \\
\hline 7 & 193 & Qua 200781 & 1 & $1 / 8$ & & 2405 & Madrid & 0 centenário de Calderon em Madrid III & $\begin{array}{l}\text { Enquanto Madrid tiver o seu museu e o deixar ver aos } \\
\text { estrangeiros, os }\end{array}$ & \\
\hline 7 & 194 & Qui 210781 & 1 & $1 / 8$ & & 2505 & Madrid & 0 centenário de Calderon em Madrid IV & $\begin{array}{l}\text { É o dia aniversário da morte de Calderon. A artilharia } \\
\text { anuncia este fato }\end{array}$ & \\
\hline 7 & 238 & Seg 290881 & 1 & $1 / 8$ & & 2605 & Madrid & 0 centenário de Calderon em Madrid V & $\begin{array}{l}\text { Hoje, procissão da mocidade das escolas em honra de Calderon. } \\
\text { o cortejo sai }\end{array}$ & \\
\hline 7 & 242 & Sex 020981 & 1 & $1 / 8$ & & 2705 & Madrid & 0 centenário de Calderon em Madrid VI & $\begin{array}{l}\text { Ao meio dia as deputações portuguesas reúnem-se na calle } \\
\text { Cláudio coelho, no bairro }\end{array}$ & \\
\hline 7 & 249 & Sex 090981 & 1 & $1 / 8$ & & 2905 & Madrid & 0 centenário de Calderon em Madrid VII & $\begin{array}{l}\text { Vir a Madrid e não falar de touros nem das espanholas poderia } \\
\text { parecer um acinte }\end{array}$ & \\
\hline 7 & 259 & Seg 190981 & 1 & $1 / 8$ & $\mathrm{CP}$ & 1308 & Lisboa & A prisão de Gomes Leal & $\begin{array}{l}\text { Com os primeiros calores deste verão vem ao governo uma coisa } \\
\text { que ele não tinha tido há muito tempo }\end{array}$ & * \\
\hline 7 & 272 & Sab 011081 & 1 & $1 / 8$ & $\mathrm{CP}$ & 2808 & Lisboa & A política portuguesa & $\begin{array}{l}\text { Estão feitas as }(\ldots) \text { de deputados para a futura }(\ldots) \\
\text { legislativa. } 0 \text { governo, à }\end{array}$ & * \\
\hline 7 & 283 & Qui 131081 & 1 & $1 / 8$ & $\mathrm{CP}$ & 021181 & Lisboa & Os dicionários da língua portuguesa & $\begin{array}{l}\text { Entre as obras jocosas da literatura portuguesa figuram em } \\
\text { prima linha os dicionários da língua. }\end{array}$ & \\
\hline 7 & 304 & Sex 041181 & 1 & $1 / 8$ & $\mathrm{CP}$ & 3009 & Trafaria & À borda dágua & $\begin{array}{l}\text { Não - tinha eu dito comigo logo de manhã cedo, ao abrir a } \\
\text { minha porta e ao }\end{array}$ & \\
\hline 7 & 316 & Seg 141181 & 1 & $1 / 8$ & $\mathrm{CP}$ & 2010 & Lisboa & Capitalistas portugueses e investimentos & $\begin{array}{l}0 \text { inquérito industrial a que o governo mandou proceder para o } \\
\text { fim de determinar as bases positivas }\end{array}$ & \\
\hline 7 & 322 & Dom 201181 & 1 & $1 / 8$ & $\mathrm{CP}$ & $\mathrm{s} / \mathrm{d}$ & & À borda dágua & $\begin{array}{l}\text { Conhecem decerto, como toda a gente, o patrão Joaquim Lopes. } \\
\text { É possível mesmo que, à força de o }\end{array}$ & \\
\hline 7 & 330 & Seg 281181 & 1 & $1 / 8$ & $\mathrm{CP}$ & 021181 & Lisboa & Ortego e André Gill & $\begin{array}{l}\text { Semana aziaga, semana funesta à ironia, aquela que acaba de } \\
\text { passar. Dois dos primeiros mestres da }\end{array}$ & \\
\hline 7 & 337 & Seg 051281 & 1 & $1 / 8$ & $\mathrm{CP}$ & 121181 & Lisboa & A higiene em Lisboa & $\begin{array}{l}\text { É evidente para todos os estrangeiros e é sabido de todos os } \\
\text { naturais, que a cidade de Lisboa }\end{array}$ & * \\
\hline 7 & 348 & Sex 161281 & 1 & $1 / 8$ & $\mathrm{CP}$ & 151181 & Lisboa & A queda do ministério & $\begin{array}{l}\text { Caiu o ministério! Tal é a notícia que acaba de entrar em } \\
\text { casa com os primeiros raios matutinos de }\end{array}$ & * \\
\hline 7 & 351 & Seg 191281 & 1 & $1 / 8$ & $\mathrm{CP}$ & 2111 & Lisboa & Os reis de Espanha & $\begin{array}{l}\text { Está calculada em quinhentos contos, diziam ontem dois } \\
\text { jornais, a despesa das festas da recepção }\end{array}$ & * \\
\hline 7 & 352 & Ter 201281 & 1 & $1 / 8$ & $\mathrm{CP}$ & 2711 & Lisboa & Prêmios da Real Soc. Humanitária, do Porto & $\begin{array}{l}\text { A hora em que lhes escrevo estas linhas, a Real sociedade } \\
\text { Humanitária da cidade do Porto irá }\end{array}$ & * \\
\hline- & & & 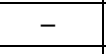 & 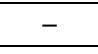 & & 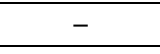 & & & & - \\
\hline 8 & 002 & Seg 020182 & 1 & $1 / 8$ & $\mathrm{CP}$ & 051281 & Lisboa & 0 tenente e o assassinato do capitão & $\begin{array}{l}\text { Um tenente chamado Freitas, do regimento de infantaria } n^{\circ} 2 \text {, } \\
\text { espancou um faxina detalhado ao seu }\end{array}$ & \\
\hline 8 & 004 & Qua 040182 & 1 & $1 / 8$ & $\mathrm{CP}$ & 121281 & Lisboa & Leilão da estrela da ópera cômica & $\begin{array}{l}\text { Davam há dias os jornais a notícia desenvolvida e } \\
\text { circunstanciada do leilão da Josefa. [A Josefa, }\end{array}$ & \\
\hline 8 & 016 & Seg 160182 & 1 & $1 / 8$ & $\mathrm{CP}$ & 151281 & Lisboa & 0 espancamento do poeta Gomes Leal & $\begin{array}{l}\text { Toda a imprensa se está ocupando neste momento de um caso de } \\
\text { espancamento de que foi objeto o poeta }\end{array}$ & * \\
\hline 8 & 023 & Seg 230182 & 1 & $1 / 8$ & $\mathrm{CP}$ & 241281 & Lisboa & Os preparativos de Lisboa para o Natal & $\begin{array}{l}\text { Lisboa prepara neste momento a festa de Natal. [Grandes } \\
\text { rebanhos de perus enrabeirados de lama, }\end{array}$ & \\
\hline 8 & 030 & Seg 300182 & 1 & $1 / 8$ & $\mathrm{CP}$ & 241281 & Lisboa & Continuação da carta anterior & $\begin{array}{l}\text { Via-a na rua Formosa às } 3 \text { horas da tarde. Era uma rapariga de } \\
\text { nove a dez anos, magra, pálida, boca }\end{array}$ & \\
\hline 8 & 032 & Qua 010282 & 1 & $1 / 8$ & $\mathrm{CP}$ & 060182 & Lisboa & Reabertura das cortes e a fala do trono & $\begin{array}{l}\text { A entrada oficial do novo ano celebrou-se há quatro dias com } \\
\text { a cerimônia de abertura solene das }\end{array}$ & \\
\hline 8 & 037 & Seg 060282 & 1 & $1 / 8$ & $\mathrm{CP}$ & 1301 & Lisboa & A visita dos reis de Espanha & $\begin{array}{l}\text { A civilização deste século dá-nos às vezes espetáculos bem } \\
\text { interessantes. [Há poucos meses, por }\end{array}$ & * \\
\hline 8 & 044 & Seg 130282 & 1 & $1 / 8$ & $\mathrm{CP}$ & 240182 & Lisboa & 0 batalhão dos alunos do Colégio Militar & $\begin{array}{l}\text { Por ocasião da grande parada em honra dos reis de Espanha, } \\
\text { abria marcha, no desfilar das tropas, }\end{array}$ & \\
\hline 8 & 053 & Qua 220282 & 1 & $1 / 8$ & $\mathrm{CP}$ & 240182 & Lisboa & Baile oferecido aos reis de Espanha & $\begin{array}{l}\text { Realizou-se com todo o luzimento próprio de festas desta } \\
\text { natureza o grande baile, oferecido aos }\end{array}$ & * \\
\hline 8 & 066 & Qua 080382 & 1 & $1 / 8$ & $\mathrm{CP}$ & 060282 & Lisboa & Liberdade de imprensa e o bispo de Viseu & $\begin{array}{l}\text { (...) finalmente nas concavidades }(\ldots) \text { da imprensa os } \\
\text { últimos }(\ldots) \text { da viagem dos reis de Espanha }\end{array}$ & \\
\hline
\end{tabular}




\begin{tabular}{|c|c|c|c|c|c|c|c|c|c|c|}
\hline ANO & NUM & DAT $\mathbf{P}$ & PAG & COL & $\mathbf{S}$ & DAT E & LOC E & TÍTULO OU ASSUNTO & PALAVRAS INICIAIS & \\
\hline 8 & 083 & Sab 250382 & 1 & $1 / 8$ & CP & 180282 & Lisboa & A Câmara e a disc. da reforma da carta & $\begin{array}{l}\text { A câmara dos deputados acaba de rejeitar pelo voto unânime de } \\
\text { toda a sua maioria uma proposta para }\end{array}$ & \\
\hline 8 & 092 & Seg 030482 & 1 & $1 / 8$ & CP & 180281 & Lisboa & Aniversário. da filha dos duques de Palmela & $\begin{array}{l}\text { Antes de ontem, } 16 \text {, dia do aniversário da jovem marquesa do } \\
\text { Fayal, filha dos duques de Palmela, }\end{array}$ & * \\
\hline 8 & 096 & Sex 070482 & 1 & $1 / 8$ & $\mathrm{CP}$ & 280282 & Lisboa & Exposição de trabalhos mecânicos no Porto & $\begin{array}{l}\text { A Sociedade de Instrução do Porto, que conta por enquanto mui } \\
\text { pouco tempo de existência, e que é já }\end{array}$ & \\
\hline 8 & 099 & Seg 100482 & 1 & $1 / 8$ & $\mathrm{CP}$ & 130382 & Lisboa & A Nação, o estudante e a eucaristia & $\begin{array}{l}\text { A Nação, jornal legitimista e beato, apareceu há dias tarjado } \\
\text { de negro, em luto pesado. Ao ver esta }\end{array}$ & \\
\hline 8 & 103 & Sab 150482 & 1 & $1 / 8$ & CP & 200382 & Lisboa & A febre em Lisboa & $\begin{array}{l}\text { Se o Rio de Janeiro faz gosto em }(\ldots) \text { instalação de um } \\
\text { lazareto }(\ldots) \text { de recreio constatada por }\end{array}$ & \\
\hline 8 & 116 & Sex 280482 & 1 & $1 / 8$ & CP & 280382 & Lisboa & Apresentação da peça Odette, de Sardou & $\begin{array}{l}\text { Temos presentemente em cena, no teatro de D. Maria, a odette, } \\
\text { de Sardou, traduzida pelo ator Brazão }\end{array}$ & \\
\hline 8 & 123 & Sex 050582 & 1 & $1 / 8$ & $\mathrm{CP}$ & 300382 & Lisboa & $\begin{array}{l}\begin{array}{l}\text { Manuscrito do séc XVIII e o Marquês de } \\
\text { Pombal }\end{array} \\
\end{array}$ & $\begin{array}{l}\text { O Sr. Fernando Palha, um dos nossos bibliófilos mais } \\
\text { distinto, possui hoje na sua livraria um }\end{array}$ & * \\
\hline 8 & 132 & Dom 140582 & 1 & $1 / 8$ & CP & 080482 & Lisboa & A morte de Guilherme de Azevedo & $\begin{array}{l}\text { Aquele que ainda resta dos dois cronistas semanais da Gazeta } \\
\text { de Noticias na Europa, traz-lhes hoje }\end{array}$ & \\
\hline 8 & 141 & Seg 220582 & 1 & $1 / 8$ & $\mathrm{CP}$ & 210482 & Lisboa & Jenner e a vacina/Froebel e a Pedagogia & $\begin{array}{l}\text { (...)municipais de Lisboa e }(\ldots) \text { hoje o centenário de }(\ldots) \\
\text { inaugurando em cada uma }(\ldots) \text { um }\end{array}$ & * \\
\hline 8 & 148 & Seg 290582 & 1 & $1 / 8$ & CP & 210482 & Lisboa & Continuação da carta anterior & $\begin{array}{l}\text { Froebel ouviu em muitas famílias este queixume freqüente: - } \\
\text { Quando meu filho era pequenino queria }\end{array}$ & * \\
\hline 8 & 153 & Sab 030682 & 1 & $1 / 8$ & CP & 280482 & Lisboa & A personalidade de Sarah Bernhardt & $\begin{array}{l}(\ldots) \text { um pouco de Sarah Bernhardt }(\ldots) \text { que não foi senão } \\
\text { dela }(\ldots) \text { Lisboa durante a última }\end{array}$ & * \\
\hline 8 & 155 & Seg 050682 & 1 & $1 / 8$ & $\mathrm{CP}$ & 050582 & Lisboa & A querela do Antonio Maria & $\begin{array}{l}\text { Foi querelado um número do Antonio Maria por haver publicado } \\
\text { um desenho de Bordalo Pinheiro, }\end{array}$ & * \\
\hline 8 & 159 & Sex 090682 & 1 & $1 / 8$ & CP & 100582 & Lisboa & Festas do cent. do Marquês de Pombal I & $\begin{array}{l}\text { As festas do centenário do Marquês de Pombal promovidas por } \\
\text { uma comissão de estudantes de }\end{array}$ & * \\
\hline 8 & 169 & Seg 190682 & 1 & $1 / 8$ & $\mathrm{CP}$ & 110582 & Lisboa & Festas do cent. do marquês de Pombal II & $\begin{array}{l}\text { No dia 7, pela } 1 \text { hora da tarde, sessão inaugural do Congresso } \\
\text { Acadêmico, em uma das salas da }\end{array}$ & * \\
\hline 8 & 175 & Seg 260682 & 1 & $1 / 8$ & CP & 110582 & Lisboa & Festas do cent. do Marquês de Pombal III & $\begin{array}{l}\text { No dia } 8 \text {, declarado por lei de grande gala, inauguração do } \\
\text { monumento que será erguido por }\end{array}$ & \\
\hline 8 & 180 & Sab 010782 & 1 & $1 / 8$ & CP & 200582 & Lisboa & Festas do cent. do Marquês de Pombal IV & $\begin{array}{l}\text { Dia 9, inauguração do Instituto de Ensino Livre, pela } \\
\text { comissão acadêmica, na mesma sala da Academia }\end{array}$ & * \\
\hline 8 & 197 & Ter 180782 & 1 & $1 / 8$ & CP & 2506 & Lisboa & Os jesuítas e o respeito ao clero & $\begin{array}{l}\text { Coisa curiosa: parece que se estava à espera de que por meio } \\
\text { do centenário do Marquês de Pombal se }\end{array}$ & \\
\hline 8 & 218 & Seg 070882 & 1 & $1 / 8$ & $\mathrm{CP}$ & 080782 & Lisboa & Pedido de exame médico no ex-governador & $\begin{array}{l}\text { Sabem já os leitores, pelo correspondente noticioso deste } \\
\text { jornal que os estudantes da escola }\end{array}$ & * \\
\hline 8 & 232 & Seg 210882 & 1 & $1 / 8$ & CP & 0882 & Lisboa & Móveis e objetos antigos de Portugal & $\begin{array}{l}(\ldots) \text { de Paris tem para a }(\ldots) \text { de obras de arte a quantia } \\
(\ldots) \text { de reis por ano. Toda a gente }\end{array}$ & * \\
\hline 8 & 276 & Qua 041082 & 1 & $1 / 8$ & $\mathrm{CP}$ & 280882 & Trafaria & Pombal e Ramalho Ortigão: opúsculo & $\begin{array}{l}\text { De mão amiga, que aperto contra o meu coração reconhecido, } \\
\text { acabo de receber pelo correio do }\end{array}$ & * \\
\hline 8 & 278 & Sex 061082 & 1 & $1 / 8$ & CP & $s / d$ & & Resposta do escritor ao opúsculo & $\begin{array}{l}\text { (...) meu empenho, respondendo à }(\ldots) \text { de José Palmela }(\ldots) \\
\text { que não é refuta-lo nem contradize-lo }\end{array}$ & * \\
\hline 8 & 288 & Seg 161082 & 1 & $1 / 8$ & CP & 120982 & Trafaria & Nossa Senhora do Monte Sameiro & $\begin{array}{l}\text { A great attraction da presente estação }(\ldots) \text { tem sido as } \\
\text { romagens }(\ldots) \text { à Nossa Senhora do Monte }\end{array}$ & \\
\hline 8 & 292 & Sex 201082 & 1 & $1 / 8$ & CP & 140982 & Trafaria & A morte de Antonio Rodrigues Sampaio & $\begin{array}{l}\text { Os jornais de Lisboa, que acabo de receber, trazem-me a } \\
\text { inesperada notícia de haver falecido ontem, }\end{array}$ & \\
\hline 8 & 295 & Seg 231082 & 1 & $1 / 8$ & $\mathrm{CP}$ & 140982 & Trafaria & Continuação da carta anterior & $\begin{array}{l}\text { Todas as manhãs, apenas acordava, Sampaio tocava a campainha, } \\
\text { e dizia a seu criado: [-Faze o favor }\end{array}$ & \\
\hline 8 & 309 & Seg 061182 & $1 / 2$ & 781 & CP & 140982 & Trafaria & Continuação da carta anterior & $\begin{array}{l}\text { Não! A eloqüência oficial, de gualdrapa lutuosa e de penacho } \\
\text { preto na cabeçada funerária, pode }\end{array}$ & \\
\hline 8 & 320 & Sex 171182 & $1 / 2$ & 781 & CP & 1510 & Lisboa & A Nação e o aniversário de D. Miguel & $\begin{array}{l}\text { Parece quase demonstrado, no momento em que lhes escrevo } \\
\text { estas linhas, que existem efetivamente em }\end{array}$ & \\
\hline 8 & 327 & Sex 241182 & $1 / 2$ & 781 & CP & 2410 & Lisboa & A Rússia dos czares & $\begin{array}{l}\text { 0 Marquês de Custine, escrevendo um livro intitulado A Rússia } \\
\text { em 1839, termina-o dizendo que é }\end{array}$ & \\
\hline
\end{tabular}




\begin{tabular}{|c|c|c|c|c|c|c|c|c|c|c|}
\hline ANO & NUM & DAT $P$ & PAG & COL & $\mathbf{S}$ & DAT E & LOC E & TÍTULO OU ASSUNTO & PALAVRAS INICIAIS & \\
\hline 8 & 335 & Sab 021282 & $1 / 2$ & 781 & $\mathrm{CP}$ & 2810 & Lisboa & Rússia subterrânea, de Stepniak & $\begin{array}{l}\text { Stepniak é o pseudônimo de um niilista emigrado na Itália. } 0 \\
\text { seu livro, a Rússia subterrânea, é a }\end{array}$ & * \\
\hline 8 & 337 & Seg 041282 & $1 / 2$ & 7812 & $\mathrm{CP}$ & $\mathrm{S} / \mathrm{d}$ & & Absolvição de Vera Zassulich & $\begin{array}{l}\text { Foi a vera Zassulich que coube inaugurar o novo sistema da } \\
\text { política niilista, assassinando com um }\end{array}$ & * \\
\hline 8 & 341 & Sex 081282 & $1 / 2$ & 812 & $\mathrm{CP}$ & $\mathrm{s} / \mathrm{d}$ & & A vida do imperador Alexandre II & $\begin{array}{l}\text { É decorrido mais de ano e meio, depois que o partido niilista } \\
\text { fez ao czar as propostas de }\end{array}$ & * \\
\hline 8 & 358 & Seg 251282 & 2 & 234 & CP & 291182 & Lisboa & Eduardo de Lemos e o G.P.de Leitura & $\begin{array}{l}\text { 0 Sr. Eduardo de Lemos, negociante português e diretor do } \\
\text { Gabinete Português de Leitura no Rio de }\end{array}$ & * \\
\hline- & - & -5 & - & - & - & - & - & -5 & 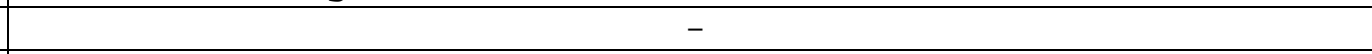 & - \\
\hline 9 & 004 & Qui 040183 & 1 & 678 & $\mathrm{CP}$ & 0112 & Lisboa & A videira e a destruição da filoxera & $\begin{array}{l}0 \text { resultado dos esforços até hoje empregados para destruir a } \\
\text { filoxera é deveras compungente. }\end{array}$ & * \\
\hline 9 & 013 & Sab 130183 & 1 & 56 & & $\mathrm{~s} / \mathrm{d}$ & & As farpas & $\begin{array}{l}\text { Andamos três dias sem podermos entender bem qual a causa do } \\
\text { conflito entre o governo de sua }\end{array}$ & \\
\hline 9 & 014 & Dom 140183 & 1 & 56 & & $\mathrm{~S} / \mathrm{d}$ & & As farpas & $\begin{array}{l}\text { Foi só no momento preciso a que escrevemos esta página, } \\
\text { depois de vários dias de estudo retroativo, }\end{array}$ & \\
\hline 9 & 034 & Sab 030283 & $1 / 2$ & 7812 & $\mathrm{CP}$ & 0201 & Lisboa & Abertertura das cortes & $\begin{array}{l}\text { À hora em que lhes escrevo está-se procedendo sessão de } \\
\text { abertura das cortes da nação portuguesa, }\end{array}$ & \\
\hline 9 & 043 & Seg 120283 & $1 / 2$ & 6781 & $\mathrm{CP}$ & 150183 & Lisboa & Espetáculo público da Ass. Comercial & $\begin{array}{l}\text { Imaginem por um momento que a Associação Comercial de Lisboa, } \\
\text { para o fim de suprir um deficit do }\end{array}$ & * \\
\hline 9 & 050 & Seg 190283 & $1 / 2$ & 7812 & $\mathrm{CP}$ & 180183 & Lisboa & 0 juramento dos deputados, na Câmara & $\begin{array}{l}\text { Depois de haver tomado assento na Câmara e prestado o devido } \\
\text { juramento, o deputado republicano }\end{array}$ & \\
\hline 9 & 065 & Ter 060383 & $1 / 2$ & 7812 & $\mathrm{CP}$ & 290183 & Lisboa & Alberto de Oliveira e outros pintores & $\begin{array}{l}\text { Cumpre-me desempenhar-me de um dever sagrado, apresentando- } \\
\text { lhes o Sr. Alberto de Oliveira. }\end{array}$ & \\
\hline 9 & 071 & Seg 120383 & 1 & 678 & $\mathrm{CP}$ & 100283 & Lisboa & Os touros e o entrudo como diversão & $\begin{array}{l}\text { Esta cidade é, como todos sabem, a capital da tristeza, assim } \\
\text { como Paris é a capital do espírito }\end{array}$ & * \\
\hline 9 & 075 & Sex 160383 & $1 / 2$ & 781 & $\mathrm{CP}$ & 190283 & Lisboa & Augusto Machado e Jerônimo Colaço & $\begin{array}{l}\text { Dois portugueses distintos, cada um ao seu gênero, - um } \\
\text { artista e um sport-man - acabam de tornar }\end{array}$ & * \\
\hline 9 & 080 & Qua 210383 & $1 / 2$ & 781 & $\mathrm{CP}$ & 250283 & Lisboa & Embalsamento de D.Inácio do Nascimento & $\begin{array}{l}\text { Ontem, } 24, \text { às } 2 \text { horas da tarde, no edifício do extinto } \\
\text { convento afonsino de cônegos regrantes de }\end{array}$ & \\
\hline 9 & 087 & Qua 280383 & $1 / 2$ & 781 & $\mathrm{CP}$ & 240283 & Lisboa & Criação em Lisboa de um Jardim Zoológico & $\begin{array}{l}\text { A grande comissão composta de } 600 \text { cidadãos, para o fim de } \\
\text { criar em Lisboa um jardim zoológico e de }\end{array}$ & \\
\hline 9 & 092 & Ter 030483 & $1 / 2$ & 781 & $\mathrm{CP}$ & 0603 & Lisboa & Localização do zoológico & $\begin{array}{l}\text { Sabe-se agora que Sua Majestade el-rei deliberou não permitir } \\
\text { que o jardim zoológico, de cujo }\end{array}$ & * \\
\hline 9 & 099 & Seg 090483 & $1 / 2$ & 781 & $\mathrm{CP}$ & 1303 & Lisboa & A morte do pintor Miguel Ângelo Lupi & $\begin{array}{l}\text { Faleceu inesperadamente, e quase subitamente, o pintor Miguel } \\
\text { Ângelo Lupi, professor da Academia de }\end{array}$ & \\
\hline 9 & 122 & Seg 230483 & $1 / 2$ & 7812 & $\mathrm{CP}$ & 2503 & Lisboa & A lei da instrução secundária & $\begin{array}{l}\text { Acaba de terminar na câmara dos Srs. Deputados a discussão da } \\
\text { nova lei de instrução secundária, }\end{array}$ & \\
\hline 9 & 124 & Qua 250483 & $1 / 2$ & 7812 & $C P$ & 2503 & Lisboa & A lei da instrução secundária & $\begin{array}{l}\text { Fala o Sr. Alberto Pimentel. Escritor público e poeta. } \\
\text { Sensibilizadoramente }\left({ }^{* *}\right) \text {, macilento }\end{array}$ & \\
\hline 9 & 127 & Sab 280483 & $1 / 2$ & 7812 & $\mathrm{CP}$ & 2503 & Lisboa & A lei da instrução secundária & $\begin{array}{l}\text { Vai longa esta resenha, e cumpre ainda resumir alguns } \\
\text { discursos indispensáveis para se formar uma }\end{array}$ & \\
\hline 9 & 120 & Seg 300483 & $1 / 2$ & 7812 & CP & 2503 & Lisboa & A lei da instrução secundária & $\begin{array}{l}\text { Fala o Sr. Mariano de Carvalho, redator político do Diário } \\
\text { Popular, chefe espiritual do partido }\end{array}$ & \\
\hline 9 & 122 & Qua 020583 & $1 / 2$ & 781 & $\mathrm{CP}$ & 2503 & Lisboa & A lei da instrução secundária & $\begin{array}{l}\text { o deputado Sr. Ilydio do Vale, professor da Escola Médico- } \\
\text { cirúrgica do Porto e relator do projeto, }\end{array}$ & \\
\hline 9 & 134 & Seg 140583 & $1 / 2$ & 781 & $\mathrm{CP}$ & 1504 & Lisboa & Mariano Pina e o falso gomoso & $\begin{array}{l}\text { Uma suave brisa belicosa acaba de atravessar Lisboa. Em menos } \\
\text { de quinze dias temos de registrar }\end{array}$ & \\
\hline 9 & 138 & Sex 180583 & $1 / 2$ & 781 & CP & 2004 & Lisboa & A Inglaterra e o incidente Bright I & $\begin{array}{l}\text { 0s leitores da Gazeta de Notícias conhecem já a nova fase em } \\
\text { que entrou a questão do domínio }\end{array}$ & * \\
\hline 9 & 140 & Dom 200583 & $1 / 2$ & 781 & $\mathrm{CP}$ & 2004 & Lisboa & A Inglaterra e o incidente Bright II & $\begin{array}{l}\text { Na sessão do dia } 18 \text { de janeiro de } 1840 \text { levantou-se na câmara } \\
\text { dos deputados, em Portugal, a questão }\end{array}$ & * \\
\hline 9 & 141 & Seg 210583 & $1 / 2$ & 7812 & $\mathrm{CP}$ & 2004 & Lisboa & A Inglaterra e 0 incidente Bright III & $\begin{array}{l}210583 \text { - São hoje decorridos quarenta e três anos depois da } \\
\text { sessão do parlamento português, em que vimos }\end{array}$ & * \\
\hline
\end{tabular}




\begin{tabular}{|c|c|c|c|c|c|c|c|c|c|c|}
\hline ANO & NUM & DAT P & PAG & COL & $\mathbf{S}$ & DAT E & LOC E & TÍTULO OU ASSUNTO & PALAVRAS INICIAIS & \\
\hline 9 & 143 & Qua 230583 & $1 / 2$ & 781 & $\mathrm{CP}$ & 3004 & Lisboa & Testamento do comendador Carvalho Peres & $\begin{array}{l}230583 \text { - Na Gazeta de Notícias do dia } 1 \text { do corrente mês leio, } \\
\text { no extrato de um testamento atribuído a um }\end{array}$ & * \\
\hline 9 & 168 & Dom 170683 & $1 / 2$ & 781 & $\mathrm{CP}$ & 1805 & Lisboa & Acerca do "Five 0'Clock Tea" & $\begin{array}{l}170683 \text { - Em desconto de Bombaim, de Goa e de Lourenço } \\
\text { Marques, a Inglaterra obsequia-nos de quando em quando }\end{array}$ & * \\
\hline 9 & 178 & Qua 270683 & $1 / 2$ & 781 & $\mathrm{CP}$ & 2105 & Lisboa & Rei português e czar russo: viagens & $\begin{array}{l}270683 \text { - Na ocasião em que lhes escrevo esta carta, acham-se } \\
\text { em viagens nos seus estados os soberanos dos }\end{array}$ & * \\
\hline 9 & 185 & Qua 040783 & $1 / 2$ & 781 & $\mathrm{CP}$ & 1505 & Lisboa & Crônica retrospectiva do High-Life & $\begin{array}{l}\text { Os encantos do inverno acabaram já, e todavia - ai de mim! - } \\
\text { os prazeres do verão não começaram }\end{array}$ & * \\
\hline 9 & 225 & Seg 130883 & $1 / 2$ & 781 & $\mathrm{CP}$ & 1307 & Lisboa & M.Cid: calígrafo e mestre de obra & $\begin{array}{l}\text { Ora aqui temos nós hoje uma instituiçãozinha, que se não } \\
\text { definhar à nascença, me parece reservada }\end{array}$ & * \\
\hline 9 & 233 & Ter 210883 & $1 / 2$ & 781 & $\mathrm{CP}$ & 1607 & Lisboa & Visita do rei ao Porto & $\begin{array}{l}\text { Sua majestade el-rei acaba de honrar o Porto com mais uma } \\
\text { dessas régias visitas, que tanto têm }\end{array}$ & * \\
\hline 9 & 262 & Qua 190983 & $1 / 2$ & 781 & NV & 0508 & Valparaíso & Sp.Steamer, cabine $n^{\circ} 19-$ Em caminho & $\begin{array}{l}\text { Não podendo, na ocasião presente, ir eu mesmo ao Brasil, } \\
\text { ousei esperar que o Brasil tivesse a }\end{array}$ & \\
\hline 9 & 263 & Sex 210983 & $1 / 2$ & 781 & NV & 1008 & Paris & As cocottes e as viagens da corte & $\begin{array}{l}\text { No Bois, cocottes. Em Éden-Theatre, cocottes. Nas Folies- } \\
\text { Bergères, cocottes. No boulevard, cocottes. Em todos }\end{array}$ & \\
\hline 9 & 267 & Ter 250983 & $1 / 2$ & 781 & NV & 1408 & $\begin{array}{l}\text { Aix-La- } \\
\text { Chapelle }\end{array}$ & Visita à catedral & $\begin{array}{l}\text { 0 comboio de Paris chega à } 1 \text { hora da noite. Em frente da gare } \\
\text { quase deserta há apenas uma carruagem, que }\end{array}$ & \\
\hline 9 & 268 & Qui 270983 & $1 / 2$ & 7812 & NV & 1708 & Colônia & Notre Dame e a catedral de Colônia & $\begin{array}{l}\text { Estive há dias com Eça de Queirós, durante duas horas, na } \\
\text { igreja de Notre Dame, em Paris. [Depois do livro }\end{array}$ & \\
\hline 9 & 274 & Seg 011083 & $1 / 2$ & 781 & NV & 1908 & Wiesbaden & Viagem a vapor pelo Reno acima & $\begin{array}{l}\text { O vapor Wilhelm, em que eu acabo de subir o Reno, encheu-se } \\
\text { completamente de passageiros em Bonn, de onde }\end{array}$ & \\
\hline 9 & 283 & Qua 101083 & $1 / 2$ & 781 & NV & 2508 & Amsterdam & - As origens & $\begin{array}{l}\text { Portugal tinha quatro séculos de existência e acabava de } \\
\text { definir o seu papel na civilização européia pelas }\end{array}$ & \\
\hline 9 & 288 & Seg 151083 & $1 / 2$ & 7812 & & $S / d$ & & A Holanda & $\begin{array}{l}\text { Em Portugal, a vida de corte havia corrompido e arruinado a } \\
\text { nobreza. [A obra de Francisco I em Versailles e }\end{array}$ & \\
\hline 9 & 295 & Seg 221083 & $1 / 2$ & 781 & & $S / d$ & & - As origens & $\begin{array}{l}\text { Assim concluída a obra de Marniz de Sant'Aldegonda, estava a } \\
\text { revolução consumada pelo filósofo e pelo }\end{array}$ & \\
\hline 9 & 296 & Ter 231083 & $1 / 2$ & 7812 & & $S / d$ & & - As origens & $\begin{array}{l}\text { Tais são os dois caracteres dominantes, que o impulso das } \\
\text { circunstâncias tornam dominadores, e cuja }\end{array}$ & \\
\hline 9 & 300 & Sab 271083 & $1 / 2$ & 7812 & & 3108 & Amsterdam & - Os aspectos exteriores & $\begin{array}{l}\text { De nenhum outro país se tem dito, como da Holanda, tão bem e } \\
\text { tão mal. As relações dos viajantes neste país }\end{array}$ & \\
\hline 9 & 302 & Seg 291083 & $1 / 2$ & 781 & NV & $\mathrm{s} / \mathrm{d}$ & & A Holanda VI - Os aspectos exteriores & $\begin{array}{l}\text { A minha carruagem pára ainda uma vez - outro hotel } \\
\text { provavelmente; mas eu é que já não tenho alento para me }\end{array}$ & \\
\hline 9 & 304 & Qua 311083 & $1 / 2$ & 781 & NV & $S / d$ & & A Holanda VII - Os aspectos exteriores & $\begin{array}{l}\text { No dia seguinte pus-me a pé às cinco horas, e a abri as } \\
\text { largas janelas do meu Quarto sobre o canal. }\end{array}$ & \\
\hline 9 & 307 & Sab 031183 & $1 / 2$ & 781 & NV & $S / d$ & & A Holanda VIII - Os aspectos exteriores & $\begin{array}{l}\text { Nas mais antigas ruas de Amsterdam, nos bairro primitivos do } \\
\text { século XIV, nas redondezas do Dam, entre o }\end{array}$ & \\
\hline 9 & 352 & Ter 181283 & $1 / 2$ & 781 & NV & $s / d$ & & A Holanda IX - Os aspectos exteriores & $\begin{array}{l}\text { Em torno de mim, dezenas de figuras vagamente conhecidas, } \\
\text { sujeitos que eu devia ter visto no Porto em }\end{array}$ & \\
\hline 9 & 354 & Qui 201283 & $1 / 2$ & 781 & NV & $S / d$ & & - Os aspectos exteriores & $\begin{array}{l}\text { Aos sábados toda a cidade de Amsterdam é revirada com o de } \\
\text { dentro para fora. o sábado é o dia especialmente }\end{array}$ & \\
\hline 9 & 364 & Dom 301283 & $1 / 2$ & 781 & NV & $\mathrm{s} / \mathrm{d}$ & & - Os aspectos exteriores & $\begin{array}{l}\text { Atraída pela exposição, toda a gente do campo vem neste } \\
\text { momento a Amsterdam, e os tipos das diferentes }\end{array}$ & \\
\hline- & - & - & 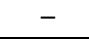 & - & - & - & - & -5 & & - \\
\hline 10 & 003 & Qui 030184 & $1 / 2$ & 781 & NV & $S / d$ & & A Holanda XII - A Paisagem & $\begin{array}{l}\text { o caçador de perdizes, o mais habituado ao campo na minha } \\
\text { terra, o mais experiente do monte, o mais perito }\end{array}$ & \\
\hline 10 & 006 & Dom 060184 & $1 / 2$ & 7812 & NV & $\mathrm{s} / \mathrm{d}$ & & A Holanda XIII - A Paisagem & $\begin{array}{l}\text { O treckschuit compõe-se de uma câmara corrida, como a caixa } \\
\text { de um grande ônibus, elevando-se a meio metro }\end{array}$ & \\
\hline 10 & 030 & Qua 300184 & $1 / 2$ & 781 & NV & $S / d$ & & - A Paisagem & $\begin{array}{l}\text { Zaadam dá bem o tipo especial da povoação holandesa. [A água } \\
\text { dos canais e do rio surpreende a cada passo o }\end{array}$ & \\
\hline 10 & 038 & Qui 070284 & 1 & 78 & NV & $S / d$ & & - A Paisagem & $\begin{array}{l}\text { A aldeia de Broek é para o asseio o extrato de carne } \\
\text { concentrado de que o resto da Holanda é o boi. }\end{array}$ & \\
\hline 10 & 046 & Sex 150284 & $1 / 2$ & 781 & NV & s/d & & A Holanda XVI - A Paisagem & $\begin{array}{l}\text { Toda a casa rústica obedece, mais ou menos fielmente, ao } \\
\text { plano daquela que acabo de descrever. De Amsterdam }\end{array}$ & \\
\hline 10 & 050 & Ter 190284 & $1 / 2$ & 781 & $\mathrm{CP}$ & 050184 & Lisboa & Confidência triste da vida alegre & $\begin{array}{l}\text { Mal estreado ano para mim o que começou há quatro dias! Além } \\
\text { de uma perda de família, que enluta o meu }\end{array}$ & \\
\hline
\end{tabular}




\begin{tabular}{|c|c|c|c|c|c|c|c|c|c|}
\hline ANO & NUM & DAT $\mathbf{P}$ & PAG & COL & $\mathbf{S}$ & DAT E & LOC E & TÍTULO OU ASSUNTO & PALAVRAS INICIAIS \\
\hline 10 & 054 & Sab 230284 & $1 / 2$ & 781 & $\mathrm{CP}$ & 050184 & Lisboa & Conf. triste da vida alegre II - cont. & $\begin{array}{l}0 \text { outro que com o novo ano partiu igualmente para a viagem de } \\
\text { que se não regressa foi Gerônimo collaço de }\end{array}$ \\
\hline 10 & 057 & Ter 260284 & $1 / 2$ & 781 & $\mathrm{CP}$ & 050184 & Lisboa & Conf. triste da vida alegre II - cont. & $\begin{array}{l}\text { No café Anglais, onde mais freqüentemente costumava jantar e } \\
\text { a que chamava num tom de sovinaria portuguesa }\end{array}$ \\
\hline 10 & 061 & Sab 010384 & 1 & 78 & $\mathrm{CP}$ & 050184 & Lisboa & Conf. triste da vida alegre IV - cont. & $\begin{array}{l}\text { No fim de novembro, pouco depois de ter eu mesmo regressado, } \\
\text { apareceu-me em Lisboa. Chegava inteiramente }\end{array}$ \\
\hline 10 & 092 & Ter 010484 & $1 / 2$ & 781 & NV & $s / d$ & & A Holanda XVII & $\begin{array}{l}\text { As cidades holandesas podem facilemente classificar-se, } \\
\text { reduzindo-as a cinco tipos principais: cidades de }\end{array}$ \\
\hline 10 & 096 & Sab 050484 & $1 / 2$ & 781 & NV & $S / d$ & & A Holanda XVIII - As cidades & $\begin{array}{l}\text { Mas a grande, a verdadeiramente indiscutível, a suprema } \\
\text { glória da cidade está nas suas fundações de }\end{array}$ \\
\hline 10 & 100 & Qua 090484 & $1 / 2$ & 781 & NV & $\mathrm{s} / \mathrm{d}$ & & A Holanda XIX & $\begin{array}{l}\text { Rotterdam é a cidade marítima por excelência; é um Amsterdam } \\
\text { salgado e cheira a algas e a marisco, assim }\end{array}$ \\
\hline 10 & 102 & Sex 110484 & $1 / 2$ & 781 & NV & $\mathrm{s} / \mathrm{d}$ & & A Holanda XX & $\begin{array}{l}\text { Para se esgotar até às fezes a taça dos prazeres babilônicos } \\
\text { de Rotterdam - que o meu companheiro de table }\end{array}$ \\
\hline 10 & 125 & Sab 030584 & $1 / 2$ & 781 & NV & $s / d$ & & A Holanda XXI & $\begin{array}{l}\text { Há uma radical diferença de ponto de vista no exercício da } \\
\text { profissão comercial entre os costumes da Holanda }\end{array}$ \\
\hline 10 & 127 & Seg 050584 & $1 / 2$ & 781 & NV & $\mathrm{s} / \mathrm{d}$ & & A Holanda XXII & $\begin{array}{l}\text { O meu fiacre prossegue, é a história da Haia e da Holanda a } \\
\text { continuar a desdobrar-se aos meus olhos em }\end{array}$ \\
\hline 10 & 137 & Sex 160584 & $1 / 2$ & 781 & NV & $S / d$ & & A Holanda XXIII & $\begin{array}{l}\text { No mês de fevereiro de } 1616 \text {, as igrejas de Haia achavam-se } \\
\text { todas ocupadas pela parte do clero sectário das }\end{array}$ \\
\hline 10 & 142 & Qua 210584 & $1 / 2$ & 781 & NV & $S / d$ & & A Holanda XXIV & $\begin{array}{l}\text { Foi ouvida por Deus a súplica do condenado;isto é: a nação } \\
\text { holandesa recebeu em si o espírito de Berneveldt. }\end{array}$ \\
\hline 10 & 144 & Sex 230584 & $1 / 2$ & 781 & NV & $s / d$ & & A Holanda XXV & $\begin{array}{l}\text { No dia em que cheguei a Haia, corrida de cavalos - primeira } \\
\text { do outono. [Planície enorme tapetada de relva }\end{array}$ \\
\hline 10 & 149 & Qua 280584 & $1 / 2$ & 781 & NV & $\mathrm{s} / \mathrm{d}$ & & A Holanda XXVI & $\begin{array}{l}\text { A população dos banhistas habita quase toda sobre as dunas, à } \\
\text { beira da água no hotel Bellevue, no hotel }\end{array}$ \\
\hline 10 & 159 & Sab 070684 & $1 / 2$ & 781 & NV & $S / d$ & & A Holanda XXVII & $\begin{array}{l}\text { Em Bronbeck, um dos lindos subúrbios de Arnhem, acha-se } \\
\text { estabelecido um asilo de soldados. [Nenhum caráter }\end{array}$ \\
\hline 10 & 169 & Ter 170684 & $1 / 2$ & 781 & NV & $s / d$ & & A Holanda XXVIII - As cidades & $\begin{array}{l}\text { Vejamos as cidades industriais.[A indústria holandesa divide- } \\
\text { se em dois grandes ramos: a indústria agrícola }\end{array}$ \\
\hline 10 & 174 & Dom 220684 & $1 / 2$ & 781 & NV & $\mathrm{s} / \mathrm{d}$ & & A Holanda XXIX & $\begin{array}{l}\text { A palavra diamante, segundo a raiz grega, quer dizer } \\
\text { dominante e esta pedra quase sobrenatural, heróica, }\end{array}$ \\
\hline 10 & 185 & Qui 030784 & $1 / 2$ & 781 & NV & $S / d$ & & A Holanda XXX & $\begin{array}{l}\text { Meia hora depois, enquanto, num canto do sofá, eu apontava } \\
\text { estas notas no meu caderno, um hóspede de barba }\end{array}$ \\
\hline 10 & 203 & Seg 210784 & $1 / 2$ & 781 & NV & S/d & & A Holanda XXXI & $\begin{array}{l}\text { No século XVII, o amor das tulipa tomou as proporções de um } \\
\text { delírio epidêmico. Foi um verdadeiro contágio, }\end{array}$ \\
\hline 10 & 216 & Dom 030884 & $1 / 2$ & 781 & NV & $s / d$ & & A Holanda XXXII & $\begin{array}{l}\text { As grandes idéias em evolução são como as escovas em } \\
\text { exercício: no princípio limpam, depois emporcalham-se }\end{array}$ \\
\hline 10 & 221 & Sex 080884 & $1 / 2$ & 781 & NV & $S / d$ & & A Holanda XXXIII - As cidades & $\begin{array}{l}\text { Por cima da porta da casa da câmara na Breedestraat (rua } \\
\text { larga) que corta toda a cidade, descrevendo um }\end{array}$ \\
\hline 10 & 233 & Qua 200884 & $1 / 2$ & 781 & NV & $s / d$ & & A Holanda XXXIV - As cidades & $\begin{array}{l}\text { Entre os indivíduos representados na coleção dos retratos do } \\
\text { Senado Acadêmico vemos: [Petreius Tiara, natural }\end{array}$ \\
\hline 10 & 247 & Qua 030984 & $1 / 2$ & 781 & NV & $\mathrm{s} / \mathrm{d}$ & & A Holanda XXXV & $\begin{array}{l}\text { Delft, pelo caráter que lhe dá a sua escola Politécnica, } \\
\text { assemelha-se a Leyde e a Utrecht. [Pela decadência }\end{array}$ \\
\hline 10 & 249 & Sex 050984 & $1 / 2$ & 781 & NV & $s / d$ & & A Holanda XXXVI & $\begin{array}{l}\text { Durante duzentos anos os produtos cerâmicos das oficinas de } \\
\text { Delft não tiveram competidores. Essa faiança }\end{array}$ \\
\hline 10 & 254 & Qua 100984 & $1 / 2$ & 781 & NV & $\mathrm{s} / \mathrm{d}$ & & $\begin{array}{l}\text { A Holanda XXXVII - As casas e os } \\
\text { indivíduos }\end{array}$ & $\begin{array}{l}\text { Na Holanda toda a embarcação lembra a casa, toda a casa } \\
\text { lembra a embarcação. A vida na água e a vida em }\end{array}$ \\
\hline 10 & 255 & Qui 110984 & $1 / 2$ & 781 & NV & $s / d$ & & $\begin{array}{l}\text { A Holanda XXXVIII - As casas e os } \\
\text { indivíduos }\end{array}$ & $\begin{array}{l}\text { A família Van Duyl habita durante o verão uma pequena casa de } \\
\text { campo numa aldeia perto das dunas, a cerca de }\end{array}$ \\
\hline 10 & 259 & Seg 150984 & $1 / 2$ & 781 & NV & $S / d$ & & $\begin{array}{l}\text { A Holanda XXXIX - As casas e os } \\
\text { indivíduos }\end{array}$ & $\begin{array}{l}\text { Na seção holandesa das belas-artes, da exposição } \\
\text { internacional de Amsterdam, figuravam vinte e sete senhoras }\end{array}$ \\
\hline 10 & 266 & Seg 220984 & $1 / 2$ & 781 & NV & $s / d$ & & - As casas e os & $\begin{array}{l}\text { Visita à vila do Sr. W... em Arnhem. [0 Sr. W... cujo nome } \\
\text { indico apenas pela sua inicial, porque ele não }\end{array}$ \\
\hline 10 & 268 & Qua 240984 & $1 / 2$ & 781 & NV & $S / d$ & & $\begin{array}{l}\text { A Holanda XLI } \\
\text { indivíduos }\end{array}$ & $\begin{array}{l}\text { A exposição das pescarias em Londres, Great International } \\
\text { Fisheries Exhibition, foi com efeito o mais }\end{array}$ \\
\hline
\end{tabular}




\begin{tabular}{|c|c|c|c|c|c|c|c|c|c|c|}
\hline ANO & NUM & DAT P & PAG & COL & $\mathbf{s}$ & DAT E & LOC E & TÍTULO OU ASSUNTO & PALAVRAS INICIAIS & \\
\hline 10 & 283 & Qui 091084 & $1 / 2$ & 781 & $\mathrm{CP}$ & 2708 & S. João da Foz & A vilegiatura & $\begin{array}{l}\text { Na sua qualidade de satélite do cólera-morbus, o medo } \\
\text { transtornou na Europa os melhores projetos da presente }\end{array}$ & * \\
\hline 10 & 288 & Ter 141084 & $1 / 2$ & 781 & $\mathrm{CP}$ & 3008 & S. João da Foz & A vilegiatura & $\begin{array}{l}\text { Os melhoramentos materiais na cidade que acabo de entrar, são } \\
\text { na verdade consideráveis. As novas ruas de }\end{array}$ & \\
\hline 10 & 294 & Seg 201084 & $1 / 2$ & 781 & $\mathrm{CP}$ & 0309 & S. João da Foz & A vilegiatura & $\begin{array}{l}\text { Ontem, visita aos museus. Os museus do Porto continuam a ser } \\
\text { dois: o do Allen, no alto da Restauração e o }\end{array}$ & * \\
\hline 10 & 298 & Sex 241084 & $1 / 2$ & 7812 & $\mathrm{CP}$ & 1309 & Foz & A vilegiatura & $\begin{array}{l}\text { São espantosos os pregressos do espírito de associação no } \\
\text { Porto. Há ainda mais associações novas do que }\end{array}$ & \\
\hline 10 & 301 & Seg 271084 & $1 / 2$ & 781 & $\mathrm{CP}$ & $s / d$ & $\begin{array}{l}\text { A Praia de } \\
\text { Espinho }\end{array}$ & A vilegiatura & $\begin{array}{l}\text { Imaginem uma grande feira. Largos arruamentos retangulares. } \\
\text { Lojas para a direita, lojas para a esquerda }\end{array}$ & \\
\hline 10 & 306 & Sab 011184 & $1 / 2$ & 781 & NV & $s / d$ & & $\begin{array}{ll}\text { A Holanda XLII } & \text { - As casas e os } \\
\text { indivíduos } & \\
\end{array}$ & $\begin{array}{l}\text { Sou obrigado a citar fatos porque - tendo vivido apenas três } \\
\text { meses na Holanda - não me julgo competente para }\end{array}$ & \\
\hline 10 & 308 & Seg 031184 & $1 / 2$ & 781 & NV & $S / d$ & & $\begin{array}{l}\text { A Holanda XLIV } \quad \text { - As casas e os } \\
\text { indivíduos }\end{array}$ & $\begin{array}{l}\text { Rotineiro é-o também o holandês, - rotineiro das suas } \\
\text { tradições, dos seus costumes, dos seus princípios }\end{array}$ & \\
\hline 10 & 309 & Ter 041184 & $1 / 2$ & 781 & NV & $s / d$ & & $\begin{array}{l}\text { A Holanda XLIII } \quad \text { - As casas e os } \\
\text { indivíduos }\end{array}$ & $\begin{array}{l}\text { Extremamente perspicaz, refletido, perseverante, no estudo e } \\
\text { na resolução de todos os problemas de economia }\end{array}$ & \\
\hline 10 & 311 & Qui 061184 & $1 / 2$ & 781 & $\mathrm{CP}$ & 2309 & Foz & A vilegiatura & $\begin{array}{l}\text { As praias de banho são em geral um divertimento de verão. A } \\
\text { questão hidroterápica é por via de regra um }\end{array}$ & \\
\hline 10 & 340 & Sex 051284 & $1 / 2$ & 781 & $\mathrm{CP}$ & 3009 & $\begin{array}{l}\text { A Praia da } \\
\text { Granja }\end{array}$ & Cartas Portuguesas I & $\begin{array}{l}\text { A povoação da Granja apresenta o aspecto de uma grande quinta } \\
\text { particular, habitada por várias famílias, para }\end{array}$ & \\
\hline 10 & 353 & Qui 181284 & $1 / 2$ & 7812 & $\mathrm{CP}$ & 0410 & No Douro & Cartas Portuguesas II & $\begin{array}{l}\text { Seis horas da manhã. Levanto-me acordado pela mais alegre } \\
\text { alvorada que melros tem jamais assobiado na fresca }\end{array}$ & \\
\hline 10 & 358 & Ter 231284 & $1 / 2$ & 781 & $\mathrm{CP}$ & 0610 & Cima-Corgo & Fabricação do vinho do Porto & $\begin{array}{l}\text { Engana-se muito quem cuida que o vinho do Porto é um simples } \\
\text { produto químico. Não. o vinho do Porto é }\end{array}$ & \\
\hline 10 & 360 & Qui 251284 & 1 & 78 & $\mathrm{CP}$ & $\mathrm{s} / \mathrm{d}$ & & Alto Douro & $\begin{array}{l}\text { Todo o comércio do vinho do Alto Douro é feito por ingleses, } \\
\text { residentes na cidade do Porto ou nos seus }\end{array}$ & \\
\hline 10 & 364 & Seg 291284 & $1 / 2$ & 781 & $\mathrm{CP}$ & $\mathrm{s} / \mathrm{d}$ & & Nas margens do Lima & $\begin{array}{l}\text { No alto das colinas, muitas das igrejas que recortam a linha } \\
\text { do horizonte têm como remate dos campanários }\end{array}$ & * \\
\hline- & - & & - & - & & - & - & & & \\
\hline 11 & 001 & Qui 010185 & $1 / 2$ & 781 & $\mathrm{CP}$ & $\mathrm{s} / \mathrm{d}$ & & Lamego & $\begin{array}{l}\text { Além de grande foco do filoxera, a região do Douro tem ainda } \\
\text { o privilégio notável de ser o foco principal }\end{array}$ & * \\
\hline 11 & $0 \odot 2$ & Sex 020185 & $1 / 2$ & 781 & $\mathrm{CP}$ & $\mathrm{s} / \mathrm{d}$ & & Continuação da carta anterior & $\begin{array}{l}\text { Elimino deste diálogo a parte que eu tive nele e que não vem } \\
\text { para o caso. o importante é o que me disseram }\end{array}$ & * \\
\hline 11 & 004 & Dom 040185 & $1 / 2$ & 781 & $\mathrm{CP}$ & 1610 & Lisboa & Nas margens do Lima & $\begin{array}{l}\text { Quem nunca veio a Vianna; quem não atravessou a bela ponte } \\
\text { sobre o rio, entre o aterro de S. Bento e a }\end{array}$ & \\
\hline 11 & 005 & Seg 050185 & $1 / 2$ & 812 & $\mathrm{CP}$ & $\mathrm{s} / \mathrm{d}$ & & Viana do Castelo & $\begin{array}{l}\text { A cidadezinha de Vianna é a capital condigna desta pitoresca } \\
\text { região. 0 viajante é agradavelmente }\end{array}$ & \\
\hline 11 & 008 & Qui 080185 & $1 / 2$ & 781 & $\mathrm{CP}$ & $s / d$ & & As mulheres de Viana & $\begin{array}{l}\text { O mercado semanal em Vianna celebra-se às sextas-feiras, num } \\
\text { largo lanço de estrada macadamizada, à beira }\end{array}$ & \\
\hline 11 & 020 & Ter 200185 & $1 / 2$ & 781 & $\mathrm{CP}$ & 0712 & Lisboa & Prisão de um jornalista I & $\begin{array}{l}\text { Na reforma penal votada em cortes na passada legislatura e } \\
\text { proposta pelo ministro Lopo Vaz de Sampaio e Melo }\end{array}$ & \\
\hline 11 & 021 & Qua 210185 & $1 / 2$ & 781 & $\mathrm{CP}$ & 0712 & Lisboa & Prisão de um jornalista II & $\begin{array}{l}\text { Entre as coisas que eu não explico nas relações do estado com } \\
\text { a opinião do país é o medo pueril dos governos }\end{array}$ & \\
\hline 11 & 022 & Qui 220185 & $1 / 2$ & 781 & $\mathrm{CP}$ & 0712 & Lisboa & Prisão de um jornalista III & $\begin{array}{l}\text { Examinemos agora a questão experimentalmente, abstraindo de } \\
\text { toda teoria de Estado, de administração, de }\end{array}$ & \\
\hline 11 & 027 & Ter 270185 & $1 / 2$ & 7812 & $\mathrm{CP}$ & 0712 & Lisboa & Prisão de um jornalista IV & $\begin{array}{l}\text { Segue-se o governo da restauração; e à semelhança do que } \\
\text { fizera a república, do que fizera Bonaparte no }\end{array}$ & \\
\hline 11 & 029 & Qui 290185 & $1 / 2$ & 781 & $\mathrm{CP}$ & 281284 & Lisboa & Proposta de reforma da constituição & $\begin{array}{l}\text { Abriu-se há dias a nova sessão legislativa, de caráter } \\
\text { constituinte; e ontem o presidente do conselho de }\end{array}$ & \\
\hline 11 & 033 & Seg 020285 & $1 / 2$ & 781 & $\mathrm{CP}$ & 050185 & & Os tremores de terra em Andaluzia & $\begin{array}{l}\text { A Europa treme. [Treme de frio? Treme de febre? Treme de } \\
\text { anêmica? Treme de pletórica? Treme da }(\ldots)\end{array}$ & * \\
\hline 11 & 035 & Qua 040285 & $1 / 2$ & 781 & $\mathrm{CP}$ & 050185 & & Continuação da carta anterior & $\begin{array}{l}\text { Pobre Andaluzia! [Que doloroso contraste entre o luto desta } \\
\text { calamidade e a sonora alegria meridional deste }\end{array}$ & * \\
\hline 11 & 040 & Seg 090285 & $1 / 2$ & 781 & $\mathrm{CP}$ & 200185 & Lisboa & 0 jornalismo português e a Andaluzia & $\begin{array}{l}0 \text { jornalismo de Lisboa quis, louvavelmente, tomar a } \\
\text { iniciativa dos socorros aos infelizes da Andaluzia, }\end{array}$ & \\
\hline 11 & 066 & Sab 070385 & $1 / 2$ & 7812 & $\mathrm{CP}$ & 2201 & & $\begin{array}{l}\text { A arte satírica em Portugal - Bordalo } \\
\text { Pinheiro I }\end{array}$ & $\begin{array}{l}\text { Acabo de receber o número do Antonio Maria, publicado ontem, } \\
\text { com a declaração de que nele finda a série }\end{array}$ & \\
\hline
\end{tabular}




\begin{tabular}{|c|c|c|c|c|c|c|c|c|c|c|}
\hline ANO & NUM & DAT $P$ & PAG & COL & $\mathbf{S}$ & DAT E & LOC E & TÍTULO OU ASSUNTO & PALAVRAS INICIAIS & \\
\hline 11 & 075 & Seg 160385 & $1 / 2$ & 7812 & $\mathrm{CP}$ & $S / d$ & & $\begin{array}{l}\text { A arte satírica em Portugal - Bordalo } \\
\text { Pinheiro II }\end{array}$ & $\begin{array}{l}\text { As animadversões, os desdens e os ódios de que as classes } \\
\text { conservadoras de Lisboa fizeram a mortalha em que }\end{array}$ & \\
\hline 11 & 085 & Qui 260385 & $1 / 2$ & 781 & $\mathrm{CP}$ & $\mathrm{S} / \mathrm{d}$ & & $\begin{array}{l}\text { A arte satírica em Portugal - Bordalo } \\
\text { Pinheiro III }\end{array}$ & $\begin{array}{l}\text { Não concluirei este estudo sem algumas palavras acerca da } \\
\text { parte que eu tive por algum tempo na redação do }\end{array}$ & \\
\hline 11 & 102 & Dom 120485 & $1 / 2$ & 7812 & $\mathrm{CP}$ & 2002 & Lisboa & No Alentejo & $\begin{array}{l}\text { "Se não viaja esta gente!..." dizia no seu tempo o autor das } \\
\text { Viagens na minha terra. - Daí cuidem que todas }\end{array}$ & * \\
\hline 11 & 108 & Sab 180485 & $1 / 2$ & 781 & $\mathrm{CP}$ & $\mathrm{s} / \mathrm{d}$ & & No Alentejo & $\begin{array}{l}\text { 0s nomes com que se designam no Alentejo as diferentes } \\
\text { categorias da propriedade rústica, soam aos ouvidos }\end{array}$ & 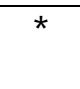 \\
\hline 11 & 117 & Seg 270485 & 1 & $1 / 8$ & $C P$ & $S / d$ & & No Alentejo III & $\begin{array}{l}\text { Évora é um museu de arqueologia. Em Portugal não há outro; } \\
\text { mas este rivaliza com os primeiros do mundo. }\end{array}$ & * \\
\hline 11 & 124 & Seg 040585 & $1 / 2$ & 781 & $\mathrm{CP}$ & $S / d$ & & No Alentejo IV & $\begin{array}{l}\text { Eis aqui a rua de "André de Resende", "mestre" Resende ou } \\
\text { "licenciado" André de Resende, como ele gostava }\end{array}$ & * \\
\hline 11 & 142 & Sex 220585 & $1 / 2$ & 781 & $\mathrm{CP}$ & $S / d$ & & No Alentejo V & $\begin{array}{l}\text { A estalagem do Aurélio, onde me hospedei, está situada à } \\
\text { esquina da rua do }(\ldots) \text {, personagem proverbial }\end{array}$ & * \\
\hline 11 & 146 & Ter 260585 & 1 & 678 & $\mathrm{CP}$ & $S / d$ & & No Alentejo VI & $\begin{array}{l}\text { A catedral, que, depois da Sé velha de Coimbra, representa um } \\
\text { dos melhores documentos que possuímos do ciclo }\end{array}$ & * \\
\hline 11 & 158 & Dom 070685 & $1 / 2$ & 812 & $\mathrm{CP}$ & $s / d$ & & No Alentejo V & $\begin{array}{l}\text { Escuso de dizer que há "Grãos }(\ldots . \text { )" em Évora, assim como em } \\
\text { Viseu, em Coimbra, em Lamego, em Lisboa, no }\end{array}$ & * \\
\hline 11 & 162 & Qui 110685 & $1 / 2$ & 812 & $\mathrm{CP}$ & $\mathrm{s} / \mathrm{d}$ & & No Alentejo VIII & $\begin{array}{l}\text { Diz-se que a gente de sociedade eborense é particularmente } \\
\text { meticulosa em questões de jerarquia. A este }\end{array}$ & * \\
\hline 11 & 166 & Seg 150685 & $1 / 2$ & 781 & $C P$ & $\mathrm{~S} / \mathrm{d}$ & & Cousas portuguesas, José J. Rodrigues & $\begin{array}{l}\text { No tempo em que vigorava a antiga estética de Platão e de } \\
\text { Aristóteles, quando se partiu do princípio que o }\end{array}$ & * \\
\hline 11 & 172 & Dom 210685 & $1 / 2$ & 781 & $\mathrm{CP}$ & $\mathrm{S} / \mathrm{d}$ & & Continuação da carta anterior & $\begin{array}{l}\text { Estudando a situação política e econômica de Portugal no } \\
\text { presente século, e comparando-a com a do século XVI }\end{array}$ & * \\
\hline 11 & 175 & Qua 240685 & $1 / 2$ & 6781 & $\mathrm{CP}$ & $\mathrm{s} / \mathrm{d}$ & & Continuação da carta anterior & $\begin{array}{l}\text { Conferindo as mais recentes estatísticas, e dando-nos os } \\
\text { resultados desenvolvidos das suas pesquisas nos }\end{array}$ & * \\
\hline 11 & 177 & Sex 260685 & $1 / 2$ & 781 & $\mathrm{CP}$ & 0306 & & Victor Hugo e o Pantheon & $\begin{array}{l}\text { Está a Europa presenciando neste momento o mais } \\
\text { extraordinário e o mais característico espetáculo do nosso }\end{array}$ & * \\
\hline 11 & 179 & Dom 280685 & $1 / 2$ & 81 & $\mathrm{CP}$ & 1705 & Lisboa & A morte de Cruz Coutinho & $\begin{array}{l}\text { Nos jornais desta manhã leio a Seguinte linha expedida } \\
\text { telegraficamente do Porto pela agência Havas: [Morreu }\end{array}$ & \\
\hline 11 & 180 & Seg 290685 & $1 / 2$ & 781 & $\mathrm{CP}$ & 1705 & Lisboa & Continuação da carta anterior & $\begin{array}{l}\text { A casa de Cruz Coutinho, aos Caldereiros, com a largura de } \\
\text { duas janelas de frente e quatro andares de }\end{array}$ & \\
\hline 11 & 184 & Sex 030785 & $1 / 2$ & 781 & $\mathrm{CP}$ & 1503 & Lisboa & Jovens oradores na Câmara & $\begin{array}{l}\text { Há dias fizeram a sua estréia na câmara dos deputados dois } \\
\text { jovens oradores, um deles da maioria ministerial }\end{array}$ & * \\
\hline 11 & 190 & Qui 090785 & $1 / 2$ & 781 & $\mathrm{CP}$ & $\mathrm{s} / \mathrm{d}$ & & Port. na época de $D$. João $V$, M. Branco & $\begin{array}{l}\text { Eis aqui um livro de } 279 \text { páginas das quais o autor teve } \\
\text { apenas o trabalho de escrever umas vinte. E quando }\end{array}$ & 岪 \\
\hline 11 & 197 & Qui 160785 & $1 / 2$ & 781 & $\mathrm{CP}$ & $s / d$ & & Continuação da carta anterior & $\begin{array}{l}\text { No meio de tanta devoção e de tanta santidade, parece que } \\
\text { nunca o mafarrico andou tanto à solta neste mundo }\end{array}$ & * \\
\hline 11 & 199 & Sab 180785 & $1 / 2$ & 781 & $\mathrm{CP}$ & $\mathrm{s} / \mathrm{d}$ & & A Holanda IV - As colônias & $\begin{array}{l}\text { Segundo um escritor holandês, que foi sub-prefeito de Java e } \\
\text { que escreveu contra o regimen colonial vigente }\end{array}$ & \\
\hline 11 & 228 & Seg 170885 & $1 / 2$ & 781 & $\mathrm{CP}$ & $\mathrm{S} / \mathrm{d}$ & & A crítica holandesa & $\begin{array}{l}\text { Dowes Dekker, mais conhecido pelo seu característico nome } \\
\text { literário de Multatuli, é um dos escritores mais }\end{array}$ & \\
\hline 11 & 239 & Sex 280885 & $1 / 2$ & 7812 & $\mathrm{CP}$ & $\mathrm{S} / \mathrm{d}$ & & As colônias neerlandesas & $\begin{array}{l}\text { A seção das colônias neerlandesas na exposição de Amsterdam } \\
\text { abrangia todo o império colonial da Holanda: as }\end{array}$ & \\
\hline 11 & 240 & Sab 290885 & $1 / 2$ & 781 & $\mathrm{CP}$ & $\mathrm{s} / \mathrm{d}$ & & As colônias neerlandesas II & $\begin{array}{l}\text { No seu todo esta exposição representa uma grande e luminosa } \\
\text { janela aberta sobre a India Holandesa, sobre a }\end{array}$ & \\
\hline 11 & 243 & Ter 010985 & $1 / 2$ & 781 & $\mathrm{CP}$ & $\mathrm{S} / \mathrm{d}$ & & As colônias neerlandesas III & $\begin{array}{l}\text { Algumas notas acerca da administração colonial da Holanda. [0 } \\
\text { que principalmente distingue a colonização }\end{array}$ & \\
\hline 11 & 244 & Qua 020985 & $1 / 2$ & 781 & $\mathrm{CP}$ & $\mathrm{s} / \mathrm{d}$ & & $\mathrm{A}$ arte holandesa & $\begin{array}{l}\text { Os séculos chamados da decadência artística são aqueles em } \\
\text { que a arte, deixando de crer na energia coletiva }\end{array}$ & \\
\hline 11 & 247 & Sab 050985 & 1 & 67 & $\mathrm{CP}$ & $S / d$ & & A arte holandesa & $\begin{array}{l}\text { A constituição física do solo e o regimen correlativo da } \\
\text { sociedade dão à arte na Holanda uma nova filosofia }\end{array}$ & \\
\hline 11 & 250 & Seg 070985 & $1 / 2$ & 812 & $\mathrm{CP}$ & $\mathrm{s} / \mathrm{d}$ & & $\mathrm{A}$ arte holandesa & $\begin{array}{l}\text { Todo o simbolismo acabou, acabaram todas as apoteoses e todas } \\
\text { as alegorias, acabaram os assuntos religiosos }\end{array}$ & \\
\hline 11 & 251 & Ter 080985 & $1 / 2$ & 781 & $\mathrm{CP}$ & $\mathrm{s} / \mathrm{d}$ & & A arte holandesa & $\begin{array}{l}\text { A única regra era aproveitar todos os recursos do ofício e do } \\
\text { talento, o desenho, a modelação, o claro-escuro }\end{array}$ & \\
\hline 11 & 252 & Qua 090985 & 1 & 78 & $C P$ & $S / d$ & & A arte holandesa & $\begin{array}{l}\text { Frans Hals, cujos quadros mais importantes se encontram no } \\
\text { museu da municipalidade do Haarlem, é igualmente }\end{array}$ & \\
\hline
\end{tabular}




\begin{tabular}{|c|c|c|c|c|c|c|c|c|c|c|}
\hline ANO & NUM & DAT $P$ & PAG & COL & $\mathbf{S}$ & DAT E & LOC E & TÍTULO OU ASSUNTO & PALAVRAS INICIAIS & \\
\hline 11 & 254 & Sex 110985 & $1 / 2$ & 781 & $\mathrm{CP}$ & $\mathrm{s} / \mathrm{d}$ & & A arte holandesa & $\begin{array}{l}\text { Resumirei agora as minhas conclusões. [A fórmula naturalista } \\
\text { da arte moderna acha-se inteiramente enunciada }\end{array}$ & \\
\hline 11 & 260 & Qui 170985 & $1 / 2$ & 781 & $\mathrm{CP}$ & $s / d$ & & John Tenório Bull I & $\begin{array}{l}\text { Elísio Mendes, regressando há poucos dias de França, trouxe- } \\
\text { me de presente, como a flor mais fina da }\end{array}$ & \\
\hline 11 & 261 & Sex 180985 & $1 / 2$ & 781 & $\mathrm{CP}$ & $\mathrm{s} / \mathrm{d}$ & & John Tenório Bull II & $\begin{array}{l}0 \text { meu enorme espanto em vista dos artigos da Pall Mall não } \\
\text { procede da natureza das cousas que eles narram, }\end{array}$ & \\
\hline 11 & 263 & Dom 200985 & $1 / 2$ & 781 & $\mathrm{CP}$ & $\mathrm{s} / \mathrm{d}$ & & John Tenório Bull III & $\begin{array}{l}\text { 0 meu bom e hoje falecido amigo Lewtas, livreiro em Lisboa, } \\
\text { tinha tido a bondade de dar-me uma carta de }\end{array}$ & \\
\hline 11 & 270 & Dom 270985 & 1 & 78 & $\mathrm{CP}$ & $S / d$ & & John Tenório Bull IV & $\begin{array}{l}\text { Foi descendo a pé e só, ao longo da Regent-Street na direção } \\
\text { de Hyde-Park, depois de ter jantado em Royal }\end{array}$ & \\
\hline 11 & 271 & Seg 280985 & $1 / 2$ & 781 & $\mathrm{CP}$ & $\mathrm{S} / \mathrm{d}$ & & John Tenório Bull V & $\begin{array}{l}\text { Já disse, mas não oponho a mínima resistência a dizer outra } \\
\text { vez, que não fui (***) terríveis. Mas li o meu }\end{array}$ & \\
\hline 11 & 272 & Ter 290985 & $1 / 2$ & 781 & $\mathrm{CP}$ & $\mathrm{S} / \mathrm{d}$ & & John Tenório Bull VI & $\begin{array}{l}\text { Não tive tampouco a ventura de saborear em Londres as doçuras } \\
\text { inefáveis da contemplação mística no dia do }\end{array}$ & \\
\hline 11 & 279 & Qua 071085 & 1 & 78 & $\mathrm{CP}$ & $S / d$ & & John Tenório Bull VII & $\begin{array}{l}\text { Nunca também em dias da minha vida, tanto como nessa noite, } \\
\text { me tocou o amorável e delicado conforto de uma }\end{array}$ & \\
\hline 11 & 315 & Qua 111185 & 1 & 78 & $\mathrm{CP}$ & 1110 & Porto & Capelo e Ivens no Porto I & $\begin{array}{l}\text { Capello e Ivens, os dois heróicos exploradores da África, } \\
\text { chegaram ontem ao Porto, em viagem de triunfo. Um }\end{array}$ & * \\
\hline 11 & 319 & Dom 151185 & 1 & 78 & $\mathrm{CP}$ & 1110 & Porto & Capelo e Ivens no Porto I & $\begin{array}{l}\text { No palácio municipal, adornado em gala, o presidente da } \\
\text { câmara leu a seguinte mensagem: [“Meus senhores.- }\end{array}$ & * \\
\hline 11 & 321 & Ter 171185 & 1 & 78 & $\mathrm{CP}$ & 1310 & Porto & Capelo e Ivens no Porto II & $\begin{array}{l}\text { Antes de ontem, recepção dos africanistas no Ateneu } \\
\text { Comercial, e ontem na bolsa. [0 Ateneu é um clube de }\end{array}$ & * \\
\hline 11 & 323 & Qui 191185 & 1 & 78 & $\mathrm{CP}$ & 1310 & Porto & Capelo e Ivens no Porto II (conclusão) & $\begin{array}{l}0 \text { museu industrial, de cuja falta eu então amargamente me } \\
\text { queixava em uma carta escrita daqui, e publicada }\end{array}$ & * \\
\hline 11 & 335 & Ter 011285 & 1 & 78 & $\mathrm{CP}$ & 1510 & Porto & Capelo e Ivens no Porto III & $\begin{array}{l}\text { Na Associação Comercial a sessão solene da recepção dos dois } \\
\text { viajantes realizou-se na grande sala em estilo }\end{array}$ & * \\
\hline 11 & 336 & Qua 021285 & 1 & 8 & $\mathrm{CP}$ & 1510 & Porto & Capelo e Ivens no Porto III (conclusão) & $\begin{array}{l}\text { "As margens do Tanganica e do lago Moero, bem como as do } \\
\text { curso médio do Qualaba, ardem em constantes guerras }\end{array}$ & * \\
\hline- & - & - & - & - & - & - & - & - & - & - \\
\hline 12 & 010 & Dom 100186 & 1 & 78 & & $\mathrm{~s} / \mathrm{d}$ & & $\begin{array}{l}\text { História de um ano - } 1885 \text { I } 0 \text { mês de } \\
\text { janeiro }\end{array}$ & $\begin{array}{l}\text { Não há - sinto dizê-lo - diferença palpável entre o }\left(^{* * *}\right) \\
\text { como começou o ano de 1885, e aquele como começou }\end{array}$ & \\
\hline 12 & 011 & Seg 110186 & 1 & 78 & & $\mathrm{~S} / \mathrm{d}$ & & $\begin{array}{l}\text { História de um ano - } 1885 \text { I } 0 \text { mês de } \\
\text { janeiro }\end{array}$ & $\begin{array}{l}\text { A pequena dosagem dos princípios calcários, não só na } \\
\text { constituição do solo como na da atmosfera, em uma }\end{array}$ & \\
\hline 12 & 012 & Ter 120186 & 1 & 78 & & $S / d$ & & $\begin{array}{l}\text { História de um ano - } 1885 \text { II } 0 \text { mês de } \\
\text { fevereiro }\end{array}$ & $\begin{array}{l}\text { Lisboa valsa. [No Paço da Ajuda os criados vestem os calções } \\
\text { curtos e a farda encarnada, põe-se a grande }\end{array}$ & * \\
\hline 12 & 014 & Qui 140186 & 1 & 78 & & $\mathrm{~S} / \mathrm{d}$ & & $\begin{array}{l}\text { História de um ano - } 1885 \text { II } 0 \text { mês de } \\
\text { fevereiro }\end{array}$ & $\begin{array}{l}\text { S. Ex. nunca viajou quer no país, quer no resto da Europa, } \\
\text { como simples touriste curioso e modesto, }\end{array}$ & * \\
\hline 12 & 025 & Seg 250186 & 1 & 78 & & $S / d$ & & $\begin{array}{l}\text { História de um ano - } 1885 \text { II } 0 \text { mês de } \\
\text { fevereiro }\end{array}$ & $\begin{array}{l}\text { Além da valsa - Parla! - Cantada em S. Carlos pela Sembrich, } \\
\text { nada mais ocorreu de notável no presente mês, }\end{array}$ & * \\
\hline 12 & 028 & Qui 280186 & 1 & 78 & & $S / d$ & & $\begin{array}{l}\text { História de um ano - } 1885 \text { II } 0 \text { mês de } \\
\text { fevereiro }\end{array}$ & $\begin{array}{l}0 \text { problema de proteção do estado às classes trabalhadoras } \\
\text { envolve duas questões: primeira, a que se refere }\end{array}$ & * \\
\hline 12 & 048 & Qua 170286 & 1 & 78 & & $S / d$ & & $\begin{array}{l}\text { História de um ano - } 1885 \text { III } 0 \text { mês de } \\
\text { março }\end{array}$ & $\begin{array}{l}\text { No decurso deste mês entrou em Lisboa a primavera e o conde } \\
\text { de camonde. [Depois da morte do visconde de }\end{array}$ & \\
\hline 12 & 049 & Qui 180286 & 1 & 78 & & $S / d$ & & $\begin{array}{l}\text { História de um ano - } 1885 \text { III } 0 \text { mês de } \\
\text { março }\end{array}$ & $\begin{array}{l}\text { Venero Camonde, porque vejo na personalidade deste hebreu o } \\
\text { próprio Judeu Errante, e figura-se ao meu }\end{array}$ & \\
\hline 12 & 050 & Sex 190286 & 1 & 78 & & $S / d$ & & $\begin{array}{l}\text { História de um ano - } 1885 \text { IV } 0 \text { mês de } \\
\text { abril }\end{array}$ & $\begin{array}{l}\text { Engrolou-se a quaresma o mais divertidamente que se } \\
\text { pôde. [Para esse efeito contribuiu com eficácia o }\end{array}$ & \\
\hline 12 & 051 & Sab 200286 & 1 & 78 & & $S / d$ & & $\begin{array}{l}\text { História de um ano - } 1885 \text { IV } 0 \text { mês de } \\
\text { abril }\end{array}$ & $\begin{array}{l}\text { As prateirinhas de hervilhaca ou de trigo grelhado, chamadas } \\
\text { ainda "jardins de Adonis", não são o único }\end{array}$ & \\
\hline 12 & 082 & Ter 230386 & $1 / 2$ & 781 & & $S / d$ & & História de um ano - $1885 \mathrm{~V} \quad 0$ mês de maio & $\begin{array}{l}\text { Abre a Feira das Amoreiras, vai-se ao campo colher a espiga } \\
\text { na quinta-feira da Ascensão, e começam as }\end{array}$ & \\
\hline 12 & 086 & Sab 270386 & $1 / 2$ & 781 & $\mathrm{CP}$ & $\mathrm{S} / \mathrm{d}$ & & A Figueira da Foz & $\begin{array}{l}\text { Não tem outro remédio senão vir à Figueira, quem quiser ver a } \\
\text { mais linda praia de banhos de Portugal. }\end{array}$ & \\
\hline 12 & 089 & Ter 300386 & 1 & 78 & $\mathrm{CP}$ & 1702 & Lisboa & A nova louça das Caldas I & $\begin{array}{l}\text { Nas salas da redação do Comércio de Portugal, onde há poucos } \\
\text { dias ainda se encerrava uma exposição de }\end{array}$ & \\
\hline 12 & 093 & Sab 030486 & $1 / 2$ & 781 & $\mathrm{CP}$ & 1702 & Lisboa & A nova louça das Caldas II & $\begin{array}{l}\text { O capital da nova empresa é de }(\ldots) \text { contos de réis, tendo-se } \\
\text { feito apenas a primeira emissão de } 100 \text { contos }\end{array}$ & \\
\hline
\end{tabular}




\begin{tabular}{|c|c|c|c|c|c|c|c|c|c|c|}
\hline ANO & NUM & DAT $P$ & PAG & COL & $\mathbf{s}$ & DAT E & LOC E & TÍTULO OU ASSUNTO & PALAVRAS INICIAIS & \\
\hline 12 & 096 & Ter 060486 & $1 / 2$ & 781 & $\mathrm{CP}$ & 1702 & Lisboa & A nova louça das Caldas III & $\begin{array}{l}\text { Nos produtos cerâmicos de Bordalo Pinheiro, cumpre } \\
\text { distinguir, para os classificar na arte moderna, a }\end{array}$ & * \\
\hline 12 & 106 & Sex 160486 & $1 / 2$ & 781 & & $S / d$ & & $\begin{array}{l}\text { História de um ano - } 1885 \text { VI } 0 \text { mês de } \\
\text { junho }\end{array}$ & $\begin{array}{l}\text { Durante este mês, os jornais do partido regenerador e os } \\
\text { jornais do partido republicano ocuparam-se }\end{array}$ & * \\
\hline 12 & 138 & Ter 180586 & $1 / 2$ & 812 & & $S / d$ & & $\begin{array}{l}\text { História de um ano - } 1885 \quad 0 \text { mês de } \\
\text { julho }\end{array}$ & $\begin{array}{l}\text { Morre no Porto o editor Ernesto Chardron, cujo nome ocupa na } \\
\text { história da livraria portuguesa deste século }\end{array}$ & \\
\hline 12 & 139 & Qua 190586 & 1 & 78 & & $\mathrm{~s} / \mathrm{d}$ & & $\begin{array}{l}\text { História de um ano - } 1885 \quad 0 \text { mês de } \\
\text { agosto }\end{array}$ & $\begin{array}{l}\text { É posto à venda o livro de Guerra Junqueiro A velhice do } \\
\text { Padre Eterno, e esta obra com a de Oliveira Martins }\end{array}$ & \\
\hline 12 & 141 & Sex 210586 & $1 / 2$ & 781 & & $\mathrm{~s} / \mathrm{d}$ & & $\begin{array}{l}\text { História de um ano - } 1885 \\
\text { agosto }\end{array}$ & $\begin{array}{l}\text { A alma poética do nosso tempo não ficou naturalmente } \\
\text { indiferente à crise da religião, ao vácuo feito em todo }\end{array}$ & \\
\hline 12 & 161 & Qui 100686 & 1 & 8 & $\mathrm{CP}$ & 1305 & Lisboa & o casamento do príncipe & $\begin{array}{l}\text { Dentro de alguns dias deve achar-se casado S.A. O príncipe D. } \\
\text { Carlos com a princesa Amélia de orleans. }\end{array}$ & * \\
\hline 12 & 162 & Sex 110686 & 1 & 67 & $\mathrm{CP}$ & 1305 & Lisboa & Continuação da carta anterior & $\begin{array}{l}0 \text { marquês de Loulé foi abafado com o mesmo cobrejão de que } \\
\text { usava o infante D. Miguel nas suas noitadas, }\end{array}$ & * \\
\hline 12 & 163 & Sab 120686 & 1 & 78 & $\mathrm{CP}$ & 1305 & Lisboa & Continuação da carta anterior & $\begin{array}{l}\text { Em 1869, quando conheci em Paris Alexandre Dumas, pai, } \\
\text { habitava ele um modesto quarto andar no boulevard }\end{array}$ & * \\
\hline 12 & 164 & Dom 130686 & 2 & 1 & $\mathrm{CP}$ & 1305 & Lisboa & Continuação da carta anterior & $\begin{array}{l}\text { Em resultado de todas as referidas considerações, com relação } \\
\text { ao casamento de que se trata, eu não tenho }\end{array}$ & * \\
\hline 12 & 167 & Qua 160686 & 1 & 8 & $\mathrm{CP}$ & 1905 & Lisboa & 0 casamento do príncipe real & $\begin{array}{l}\text { Com o fim de adornar decorosamente para a celebração do } \\
\text { casamento a igreja de } \mathrm{S} \text {. Domingos, mandou o governo }\end{array}$ & * \\
\hline 12 & 172 & Seg 210686 & 1 & 78 & $\mathrm{CP}$ & 1905 & Lisboa & 0 casamento do príncipe real - conclusão & $\begin{array}{l}\text { 0 docel e o espaldar do sólio patriarcal é de veludo vermelho } \\
\text { bordado a ouro. o docel da tribuna real é }\end{array}$ & * \\
\hline 12 & 177 & Sab 260686 & 1 & 78 & $\mathrm{CP}$ & 2905 & Lisboa & 0 casamento do príncipe & $\begin{array}{l}\text { Para as festas das ruas construíram-se por conta do } \\
\text { ministério das obras públicas, dois palanques na avenida }\end{array}$ & * \\
\hline 12 & 178 & Dom 270686 & 1 & 78 & $\mathrm{CP}$ & 2905 & Lisboa & 0 casamento do príncipe & $\begin{array}{l}\text { Os dois tanques do Terreiro do Paço são inteiramente } \\
\text { ridículos. 0 aspecto de um lago só é belo debaixo de }\end{array}$ & * \\
\hline 12 & 179 & Seg 280686 & $1 / 2$ & 812 & $\mathrm{CP}$ & 2505 & Lisboa & o casamento do príncipe & $\begin{array}{l}\text { Para a festa militar substituíram-se à pressa e à última hora } \\
\text { os antigos uniformes do exército pelos }\end{array}$ & * \\
\hline 12 & 199 & Dom 180786 & 2 & 123 & $\mathrm{CP}$ & 0505 & Lisboa & As receitas e as despesas do governo & $\begin{array}{l}\text { Antes de entrarmos na análise das diversas manifestações de } \\
\text { júbilo de Lisboa por ocasião do casamento do }\end{array}$ & * \\
\hline 12 & 211 & Sex 300786 & $1 / 2$ & 781 & $\mathrm{CP}$ & $S / d$ & & $\begin{array}{l}\text { História de um ano - } 1885 \\
\text { dezembro }\end{array}$ & $\begin{array}{l}\text { 0 fim deste ano foi assinalado pela morte de dois homens, } \\
\text { cujos nomes mereceriam ficar por algum tempo na }\end{array}$ & \\
\hline 12 & 214 & Seg 020886 & 1 & 78 & $\mathrm{CP}$ & $S / d$ & & História de um ano - 1885 & $\begin{array}{l}\text { No dia } 14 \text {, por volta do meio-dia, o rei D. Fernando exalava o } \\
\text { último suspiro no seu lindo quarto de dormir }\end{array}$ & \\
\hline 12 & 216 & Qua 040886 & 1 & 7 & $\mathrm{CP}$ & $\mathrm{s} / \mathrm{d}$ & & História de um ano - 1885 & $\begin{array}{l}\text { Considerava a língua portuguesa como o mais pitorescamente } \\
\text { expressivo e o mais enérgico de todos os idiomas }\end{array}$ & \\
\hline 12 & 227 & Dom 150886 & 1 & 78 & $\mathrm{CP}$ & $S / d$ & & Acerca da nevrose nacional I & $\begin{array}{l}\text { A soma total das diversas despesas a que deu origem o } \\
\text { casamento de sua alteza o príncipe real, acha-se }\end{array}$ & \\
\hline 12 & 234 & Dom 220886 & 1 & 78 & $\mathrm{CP}$ & $\mathrm{s} / \mathrm{d}$ & & História de um ano - 1885 & $\begin{array}{l}\text { Pode-se dizer ainda que foi D. Fernando que fez de Sintra a } \\
\text { linda vila de vilegiatura que ela hoje é. }\end{array}$ & \\
\hline 12 & 235 & Seg 230886 & 1 & 78 & $\mathrm{CP}$ & $\mathrm{s} / \mathrm{d}$ & & $\begin{array}{l}\text { História de um ano - } 1885 \\
\text { conclusão }\end{array}$ & $\begin{array}{l}0 \text { testamento de D. Fernando, contendo as disposições mais } \\
\text { eloqüentemente destinadas a favorecer os }\end{array}$ & \\
\hline 12 & 237 & Qua 250886 & 1 & 78 & $\mathrm{CP}$ & $S / d$ & & Acerca da nevrose nacional III & $\begin{array}{l}0 \text { rei Luís da Baviera era melômano, e por muito tempo esta } \\
\text { vesânia lírica, esta preocupação mórbida dos }\end{array}$ & \\
\hline 12 & 241 & Dom 290886 & $1 / 2$ & 781 & $\mathrm{CP}$ & $s / d$ & & Acerca da nevrose nacional IV & $\begin{array}{l}\text { Além da mania religiosa, há porém outra de que fomos atacados } \\
\text { com igual intensidade. [Refiro-me à mania das }\end{array}$ & \\
\hline 12 & 242 & Seg 300886 & $1 / 2$ & 781 & $\mathrm{CP}$ & s/d & & Acerca da nevrose nacional $\mathrm{V}$ & $\begin{array}{l}\text { Poucos anos depois, sepultada em África a independência da } \\
\text { pátria os de }(\ldots) \text { empenham-se e arruínam-se }\end{array}$ & \\
\hline 12 & 243 & Ter 310886 & $1 / 2$ & 812 & $\mathrm{CP}$ & 1507 & $\begin{array}{l}\text { Caldas da } \\
\text { Rainha }\end{array}$ & $\mathrm{Na}$ Extremadura & $\begin{array}{l}\text { Saio de Lisboa, às } 8 \text { horas da manhã... [Uma destas bela manhãs } \\
\text { criadoras, em que as abóboras e os melôes }\end{array}$ & \\
\hline 12 & 245 & Qui 020986 & 1 & 78 & $\mathrm{CP}$ & 1507 & $\begin{array}{l}\text { Caldas da } \\
\text { Rainha }\end{array}$ & Continuação da carta anterior & $\begin{array}{l}\text { A linda vila das Caldas da Rainha é o centro de vilegiatura } \\
\text { que em Portugal mais se parece com as Terras de }\end{array}$ & \\
\hline 12 & 251 & Qua 080986 & $1 / 2$ & 781 & $\mathrm{CP}$ & $s / d$ & & A vila d'óbidos & $\begin{array}{l}\text { Restabeleçam sobre os alicerces que ainda existem, alguns dos } \\
\text { velhos edifícios arrasados pelo tempo ou }\end{array}$ & \\
\hline 12 & 256 & Seg 130986 & $1 / 2$ & 781 & $\mathrm{CP}$ & $s / d$ & & Alcobaça & $\begin{array}{l}\text { O mosteiro de Alcobaça, tal como o venho encontrar neste mês } \\
\text { de julho de 1886, é ainda apesar de todas as }\end{array}$ & \\
\hline
\end{tabular}




\begin{tabular}{|c|c|c|c|c|c|c|c|c|c|c|}
\hline ANO & NUM & DAT $\mathbf{P}$ & PAG & COL & $\mathbf{S}$ & DAT E & LOC E & TÍTULO OU ASSUNTO & PALAVRAS INICIAIS & \\
\hline 12 & 272 & Qua 290986 & $1 / 2$ & 781 & $\mathrm{CP}$ & $\mathrm{s} / \mathrm{d}$ & & Alcobaça I & $\begin{array}{l}0 \text { meu companheiro nesta excursão, o Sr. Albrecht } \\
\text { Haupt, arquiteto alemão, professor da Real Escola Técnica }\end{array}$ & \\
\hline 12 & 293 & Qua 201086 & $1 / 2$ & 781 & $\mathrm{CP}$ & $\mathrm{S} / \mathrm{d}$ & & Alcobaça III & $\begin{array}{l}\text { 0 mosteiro de Alcobaça era além disso o asilo inviolavelmente } \\
\text { fortificado da ciência, tal como ele existia }\end{array}$ & \\
\hline 12 & 295 & Sex 221086 & $1 / 2$ & 781 & $\mathrm{CP}$ & $\mathrm{s} / \mathrm{d}$ & & Alcobaça IV & $\begin{array}{l}\text { Ao entrarmos no mosteiro pela grande porta chamada da } \\
\text { cozinha, na fachada principal, um soldado de sentinela }\end{array}$ & * \\
\hline 12 & 297 & Dom 241086 & $1 / 2$ & 781 & $\mathrm{CP}$ & $\mathrm{s} / \mathrm{d}$ & & Alcobaça V & $\begin{array}{l}\text { Na grande e alegre praça da vila, debaixo das suas belas } \\
\text { árvores, em frente da fachada do mosteiro, cor de }\end{array}$ & * \\
\hline 12 & 310 & Sab 061186 & $1 / 2$ & 781 & $\mathrm{CP}$ & $S / d$ & & A igreja da Batalha & $\begin{array}{l}\text { Como os indivíduos vulgarmente chamados "brutos da fortuna", } \\
\text { a Batalha é um monumento excepcionalmente feliz }\end{array}$ & * \\
\hline 12 & 312 & Seg 081186 & $1 / 2$ & 781 & $\mathrm{CP}$ & $\mathrm{S} / \mathrm{d}$ & & A igreja da Batalha II & $\begin{array}{l}\text { De onde é que foi transplantado para terra portuguesa este } \\
\text { produto de uma civilizaça superior, em que o }\end{array}$ & * \\
\hline 12 & 314 & Qua 101186 & 1 & 78 & $\mathrm{CP}$ & $\mathrm{s} / \mathrm{d}$ & & A igreja da Batalha III & $\begin{array}{l}\text { A harmonia perfeita e a correção puríssima de todo e de cada } \\
\text { uma das partes do monumento - circunstância }\end{array}$ & * \\
\hline 12 & 341 & Ter 071286 & $1 / 2$ & 781 & $\mathrm{CP}$ & 2210 & $\begin{array}{l}\text { Cova da } \\
\text { Piedade }\end{array}$ & Onde o autor passou o verão & $\begin{array}{l}\text { Escrevo-lhes estas linhas de uma pequena, mas bem } \\
\text { interessante povoação, aonde vim passar o verão. }\end{array}$ & * \\
\hline 12 & 342 & Qua 081286 & $1 / 2$ & 781 & $\mathrm{CP}$ & 2310 & $\begin{array}{l}\text { Cova da } \\
\text { Piedade }\end{array}$ & Os dias 23 e 24 de julho de 1833 & $\begin{array}{l}\text { As condições biológicas favorecem neste sítio, ao que parece, } \\
\text { a longevidade humana, porque noto que Quase }\end{array}$ & * \\
\hline 12 & 354 & Seg 201286 & $1 / 2$ & 781 & $\mathrm{CP}$ & 2310 & $\begin{array}{l}\text { Cova da } \\
\text { Piedade }\end{array}$ & Os dias 23 e 24 de julho de 1833 & $\begin{array}{l}\text { Sabe-se o que durante a noite de } 23 \text { para } 24 \text { se passou em } \\
\text { Lisboa. [Um dos meus vizinhos da Cova da Piedade é o }\end{array}$ & * \\
\hline 10 & 000 & & & $701+3+3$ & & - & & & & 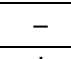 \\
\hline 13 & 003 & Seg 030187 & $1 / 2$ & 781 & $C P$ & 2911 & Lisboa & 0 regresso do rei & $\begin{array}{l}\text { A estação de inverno começa desta vez sob os mais jubilosos } \\
\text { auspícios. [Sua Majestade El-Rei }\end{array}$ & * \\
\hline 13 & 055 & Qui 240287 & $1 / 2$ & 7812 & $\mathrm{CP}$ & 2501 & Lisboa & Ocorrências da vida de Lisboa & $\begin{array}{l}\text { Não tenho que lastimar-me excessivamente pela circunstância } \\
\text { de ter estado de cama e doente mais }\end{array}$ & * \\
\hline 13 & 072 & Dom 130387 & $1 / 2$ & 781 & $\mathrm{CP}$ & 2801 & Lisboa & Fontes Pereira de Melo I & $\begin{array}{l}\text { Para biografar um homem eminente, para determinar a porção de } \\
\text { energia que ele representa na }\end{array}$ & \\
\hline 13 & 079 & Dom 200387 & $1 / 2$ & 781 & $\mathrm{CP}$ & 2801 & Lisboa & Fontes Pereira de Melo II & $\begin{array}{l}\text { 0s diferentes partidos que desde } 1851 \text { até hoje se têm } \\
\text { revezado no poder com o primitivo partido }\end{array}$ & \\
\hline 13 & 081 & Ter 220387 & $1 / 2$ & 81 & $\mathrm{CP}$ & 2801 & Lisboa & Fontes Pereira de Melo I II & $\begin{array}{l}\text { Nele se reuniam todas as condições que no trato dos homens } \\
\text { cativam o respeito da autoridade }\end{array}$ & \\
\hline 13 & 100 & Dom 100487 & 1 & 78 & $\mathrm{CP}$ & 1503 & Lisboa & Presente ao imperador da Alemanha & $\begin{array}{l}\text { A joalheria Leitão acaba de expor ao público, por um dia, a } \\
\text { espada de honra encomendada àquele }\end{array}$ & * \\
\hline 13 & 108 & Seg 180487 & $1 / 2$ & 781 & $C P$ & 1703 & Lisboa & A gravidez da rainha: expectativas & $\begin{array}{l}\text { Desde o dia } 9 \text { do corrente, que Lisboa espera o nascimento, } \\
\text { previamente anunciado para esse dia, às }\end{array}$ & * \\
\hline 13 & 111 & Qui 210487 & $1 / 2$ & 781 & & $\mathrm{~s} / \mathrm{d}$ & & Eça de Queirós & $\begin{array}{l}\text { Eça de Queirós é um dos artistas em cujas obras mais } \\
\text { claramente se patenteia a influência de seu }\end{array}$ & \\
\hline 13 & 112 & Sex 220487 & $1 / 2$ & 781 & & $\mathrm{~s} / \mathrm{d}$ & & Eça de Queirós - concl. & $\begin{array}{l}\text { Como escritor, Eça de Queirós encheu a sua palheta das tintas } \\
\text { mais variadas. [Criou a fonte dos }\end{array}$ & \\
\hline 13 & 115 & Seg 250487 & $1 / 2$ & 7812 & $\mathrm{CP}$ & 2803 & Lisboa & Nascimento do filho de D. Carlos & $\begin{array}{l}\text { No dia } 21 \text {, segunda-feira, às nove horas e um quarto da noite, } \\
\text { várias girândolas de foguetes }\end{array}$ & * \\
\hline 13 & 125 & Qui 050587 & $1 / 2$ & 781 & $\mathrm{CP}$ & 3103 & Lisboa & Fim da estação de ópera de S. Carlos & $\begin{array}{l}\text { Vai terminar amanhã ou depois de amanhã a estação da ópera em } \\
\text { são carlos. Com o aparecimento das }\end{array}$ & * \\
\hline 13 & 223 & Qui 110887 & 1 & 7 & & $\mathrm{~s} / \mathrm{d}$ & & Coração: Carta a Ferreira de Araújo & $\begin{array}{l}\text { Meu caro Ferreira de Araújo - Coração poderia ser, naquela } \\
\text { estimável figura de retórica em que nos }\end{array}$ & * \\
\hline 13 & 254 & Dom 110987 & 2 & 23 & & $\mathrm{~S} / \mathrm{d}$ & & Discurso na inauguração do G.P.Leitura & $\begin{array}{l}\text { Colocando na terra americana as primeira bases da futura } \\
\text { nação brasileira, os nossos antepassados estabeleceram no }\end{array}$ & * \\
\hline- & - & & - & - & - & - & - & 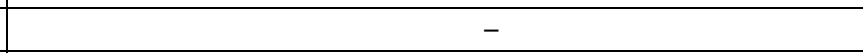 & & - \\
\hline 14 & 039 & Qua 080288 & $1 / 2$ & 781 & & $\mathrm{~s} / \mathrm{d}$ & & Um dia na pampa & $\begin{array}{l}\text { Neste domingo, } 6 \text { de novembro de 1887, tinha eu um convite } \\
\text { para almoçar com mais trinta }\end{array}$ & \\
\hline 14 & 078 & Dom 180388 & $1 / 2$ & 781 & $\mathrm{CP}$ & $\mathrm{s} / \mathrm{d}$ & & Estúpida! I & $\begin{array}{l}\text { Utilizando-me do expressivo epíteto que serve de título a } \\
\text { estas linhas, é à cidade de Lisboa que eu me }\end{array}$ & * \\
\hline 14 & 079 & Seg 190388 & $1 / 2$ & 781 & $\mathrm{CP}$ & $S / d$ & & Estúpida! II & $\begin{array}{l}\text { No dia seguinte, para o fim de estar no Lazareto às } 8 \text { horas } \\
\text { da manhã, segundo o prazo que fora dado pelos }\end{array}$ & * \\
\hline 14 & 080 & Ter 200388 & $1 / 2$ & 781 & $\mathrm{CP}$ & $\mathrm{s} / \mathrm{d}$ & & Estúpida! III & $\begin{array}{l}\text { No ponto de vista científico, a quarentena, ao que posso ver } \\
\text { das mais recentes conclusões do congresso }\end{array}$ & * \\
\hline 14 & 148 & Seg 280588 & $1 / 2$ & 781 & $\mathrm{CP}$ & $\mathrm{S} / \mathrm{d}$ & & Incêndio do teatro Baquet, do Porto & $\begin{array}{l}\text { Do que foi o teatro Baquet, do Porto, existe, hoje um montão } \\
\text { de ruínas, por cima das quais passou uma onda }\end{array}$ & \\
\hline
\end{tabular}




\begin{tabular}{|c|c|c|c|c|c|c|c|c|c|c|}
\hline ANO & NUM & DAT $\mathbf{P}$ & PAG & COL & $\mathbf{S}$ & DAT E & LOC E & TÍTULO OU ASSUNTO & PALAVRAS INICIAIS & \\
\hline 14 & 161 & Dom 100688 & $1 / 2$ & 781 & $\mathrm{CP}$ & $\mathrm{s} / \mathrm{d}$ & & Coquelin e Sarah Bernhardt & $\begin{array}{l}\text { Deus me defenda de pretender impingir-lhes um } \\
\text { "paralele". [esse gênero de eloqüência, tão particularmente }\end{array}$ & * \\
\hline 14 & 261 & Ter 180988 & $1 / 2$ & 781 & $\mathrm{CP}$ & 0807 & Lisboa & A exposição industrial & $\begin{array}{l}\text { Abriu-se solenemente, sob a presidência do soberano e com a } \\
\text { assistência de toda a família real, a exposição }\end{array}$ & * \\
\hline 14 & 308 & Dom 041188 & 1 & 678 & $\mathrm{CP}$ & 1088 & Lisboa & Crônica da estação finda & $\begin{array}{l}\text { Em conseqüência da condenação da praça do campo de Sant'Ana, } \\
\text { foi em Cintra que desta vez se realizou o }\end{array}$ & \\
\hline 14 & 316 & Seg 121188 & $1 / 2$ & 781 & $\mathrm{CP}$ & 1088 & Lisboa & Crônica da estação finda - cont. & $\begin{array}{l}\text { A série de bailes foi inaugurada pela princesa Amélia. A casa } \\
\text { ocupada pelos duques de Bragança é a da }\end{array}$ & \\
\hline 14 & 329 & Dom 251188 & 2 & 123 & $\mathrm{CP}$ & 1088 & Lisboa & Crônica da estação finda - cont. & $\begin{array}{l}\text { Verdadeiramente há algum tempo que o país nem pensa, nem se } \\
\text { administra, nem se governa, nem produz em rigor }\end{array}$ & \\
\hline 14 & 364 & Dom 301288 & $1 / 2$ & 781 & $\mathrm{CP}$ & $S / d$ & & A noção do amor na sociedade Portuguesa I & $\begin{array}{l}0 \text { impulso amoroso no coração lusitano, em vez de impelir } \\
\text { fantasia a voejar por instantes no país do azul }\end{array}$ & \\
\hline - & - & - & - & - & - & - & - & - & & - \\
\hline 15 & 001 & Ter 010189 & 1 & 78 & $\mathrm{CP}$ & $\mathrm{s} / \mathrm{d}$ & & A noção do amor na sociedade Portuguesa II & $\begin{array}{l}0 \text { século XVIII, em Portugal, tão lugubremente tenebroso de } \\
\text { embixamento beato, de crasso mau gosto }\end{array}$ & \\
\hline 15 & 016 & Qua 160189 & $1 / 2$ & 781 & $\mathrm{CP}$ & $\mathrm{s} / \mathrm{d}$ & & A noção do amor na sociedade Portuguesa III & $\begin{array}{l}\text { Que fazem no entanto as senhoras de Lisboa na grande netreira } \\
\text { que fermenta ao sol, cheirando }\end{array}$ & \\
\hline 15 & 154 & Seg 030689 & $1 / 2$ & 781 & $\mathrm{CP}$ & 2003 & Lisboa & Cinira Polônio: cantora brasileira & $\begin{array}{l}\text { Ora aqui temos nós um lindo argumentozinho ajudando a } \\
\text { demonstrar que a simples arte, ainda que sob }\end{array}$ & * \\
\hline 15 & 278 & Sab 051089 & $1 / 2$ & 781 & & $\mathrm{~s} / \mathrm{d}$ & & Páginas Imperfeitas Paris em 1889 I & $\begin{array}{l}\text { Excursionistas curiosos do documento gráfico e autêntico, } \\
\text { d'après nature ou d'après la bosse, têm }\end{array}$ & * \\
\hline 15 & 280 & Seg 071089 & 1 & 78 & & $\mathrm{~s} / \mathrm{d}$ & & Páginas Imperfeitas Paris em 1889 II & $\begin{array}{l}16 \text { de junho, } 8 \text { horas da manhã - Pela linha de Orleans, o } \\
\text { comboio de Bordéus atravessa a fértil e }\end{array}$ & * \\
\hline 15 & 297 & Qui 241089 & $1 / 2$ & 781 & & S/d & & Páginas Imperfeitas Paris em 1889 III & $\begin{array}{l}\text { É decididamente infindável e a mais variada que jamais } \\
\text { encontrei, a coleção de mulheres }\end{array}$ & * \\
\hline 15 & 307 & Sab 021189 & $1 / 2$ & 781 & & $\mathrm{~s} / \mathrm{d}$ & & Páginas Imperfeitas Paris em 1889 IV & $\begin{array}{l}\text { Primeira vista de olhos, do alto da torre do lindo pavilhão } \\
\text { brasileiro, ao conjunto do campo de }\end{array}$ & * \\
\hline 15 & 310 & Ter 051189 & $1 / 2$ & 781 & & $S / d$ & & Páginas Imperfeitas Paris em $1889 \mathrm{~V}$ & $\begin{array}{l}\text { De onde querem que venha hoje para a edificação dos grandes } \\
\text { monumentos (catedral ou hotel de ville) }\end{array}$ & * \\
\hline 15 & 332 & Qui 281189 & $1 / 2$ & 781 & & $\mathrm{~s} / \mathrm{d}$ & & Páginas Imperfeitas Paris em 1889 VI & $\begin{array}{l}\text { De que elementos se compõem o encanto estranho e } \\
\text { indescritível que Paris exerce sobre os }\end{array}$ & * \\
\hline 15 & 334 & Sab 301189 & 1 & 78 & $\mathrm{CP}$ & 2810 & Lisboa & Agonia e morte do rei D. Luís & $\begin{array}{l}\text { Na cidadela de Cascais acaba de falecer, ao cabo da mais } \\
\text { cruciante enfermidade, o rei D. Luís. }\end{array}$ & \\
\hline 15 & 339 & Qui 051289 & 1 & 78 & & $s / d$ & & Páginas Imperfeitas Paris em 1889 VII & $\begin{array}{l}\text { Charles Darwin, inquerido uma vez sobre qual era o mais belo } \\
\text { espetáculo da natureza que em }\end{array}$ & * \\
\hline 15 & 360 & Qui 261289 & $1 / 2$ & 7812 & $\mathrm{CP}$ & 0711 & Lisboa & o rei D. Luís & $\begin{array}{l}\text { Por qualquer lado que considere este assunto, quer no ponto } \\
\text { de vista do sentimento, quer no ponto }\end{array}$ & \\
\hline$\frac{-}{16}$ & - & $\frac{-}{-10}$ & - & - & - & - & - & - & & - \\
\hline 16 & 058 & Qui 270290 & 1 & 78 & & $\mathrm{~s} / \mathrm{d}$ & & o quadro social da revolução brasileira & $\begin{array}{l}\text { A respeito dos destinos políticos do Brasil, publicou } \\
\text { recentemente a Revista de Portugal um }\end{array}$ & * \\
\hline 16 & 059 & Sex 280290 & 1 & 78 & & $S / d$ & & 0 quadro social da revolução brasileira & $\begin{array}{l}\text { Uma noite de representação no referido teatro, entrando a } \\
\text { família imperial no seu camarote }\end{array}$ & * \\
\hline 16 & 060 & Sab 010390 & $1 / 2$ & 781 & & $\mathrm{~s} / \mathrm{d}$ & & o quadro social da revolução brasileira & $\begin{array}{l}0 \text { abolicionismo, cujo primeiro grito foi - creio eu - lançado } \\
\text { no século passado pelo padre Rocha }\end{array}$ & * \\
\hline 16 & 061 & Dom 020390 & $1 / 2$ & 781 & & $\mathrm{~s} / \mathrm{d}$ & & 0 quadro social da revolução brasileira & $\begin{array}{l}\text { No Rio de Janeiro, em consequência do usos geral de tomar o } \\
\text { bonde para transpor as mais pequenas }\end{array}$ & * \\
\hline 16 & 327 & Dom 231190 & 1 & 78 & $\mathrm{CP}$ & 1090 & Lisboa & Lord Salisbury e correlativos desgostos & $\begin{array}{l}\text { Em uma sessão do senado a que eu assisti no Rio de Janeiro, o } \\
\text { senhor Ávila, senador pelo Rio Grande }\end{array}$ & \\
\hline 16 & 328 & Seg 241190 & 1 & 78 & $\mathrm{CP}$ & 1090 & Lisboa & Lord Salisbury e correlativos desgostos & $\begin{array}{l}0 \text { brasão da Grã-Bretanha é um escudo esquartelado, tendo no } \\
\text { primeiro quartel e no quarto três }\end{array}$ & \\
\hline 16 & 329 & Ter 251190 & 1 & 78 & $\mathrm{CP}$ & 1090 & Lisboa & Lord Salisbury e correlativos desgostos & $\begin{array}{l}\text { Em vez de um ministério de concentração patriótica, tendo em } \\
\text { vista o desagravo de um cheque }\end{array}$ & \\
\hline & & & 1 & & - & & - & & & - \\
\hline 17 & 005 & Seg 050191 & 1 & 78 & & $S / d$ & & Camilo Castelo Branco & $\begin{array}{l}\text { Para quem não souber o que era há Quarenta anos a cidade do } \\
\text { Porto, será já hoje difícil a análise }\end{array}$ & \\
\hline 17 & 011 & Dom 110191 & 2 & 12 & & $\mathrm{~s} / \mathrm{d}$ & & Camilo Castelo Branco & $\begin{array}{l}\text { 0s homens arrojados e aventureiros que tinham vindo à capital } \\
\text { em oito dias de jornada em caleça, }\end{array}$ & \\
\hline
\end{tabular}




\begin{tabular}{|c|c|c|c|c|c|c|c|c|c|c|}
\hline ANO & NUM & DAT P & PAG & COL & $\mathbf{S}$ & DAT E & LOC E & TÍTULO OU ASSUNTO & PALAVRAS INICIAIS & \\
\hline 17 & 012 & Seg 120191 & 1 & 12 & & $\mathrm{~s} / \mathrm{d}$ & & Camilo Castelo Branco & $\begin{array}{l}0 \text { folhetim nascente, novo gênero literário, cultivado por } \\
\text { Evaristo Basto, Lousada, Arnaldo Gama, }\end{array}$ & \\
\hline 17 & 013 & Ter 130191 & 1 & 12 & & $s / d$ & & Camilo Castelo Branco & $\begin{array}{l}\text { Quem está na piolhice do negócio, - quer seja descontando } \\
\text { letras como na Rua dos Ingleses, quer }\end{array}$ & \\
\hline 17 & 018 & Dom 180191 & 2 & 23 & & $\mathrm{~s} / \mathrm{d}$ & & Camilo Castelo Branco & $\begin{array}{l}\text { Essa leitura será ainda para o leitor moderno uma viagem } \\
\text { retrospectiva com aparições estranhamente }\end{array}$ & \\
\hline 17 & 058 & Sex 270291 & 1 & 78 & $\mathrm{CP}$ & 0191 & Lisboa & Aspectos da sociedade portuguesa & $\begin{array}{l}\text { A crise que ultimamente atravessamos, não teve a marcha } \\
\text { constante que da }\end{array}$ & * \\
\hline 17 & 059 & Sab 280291 & $1 / 2$ & 781 & $\mathrm{CP}$ & 0191 & Lisboa & Continuação da carta anterior & $\begin{array}{l}\text { 0 vapor Malange partiu ontem para a África com o primeiro } \\
\text { turno da expedição }\end{array}$ & * \\
\hline 17 & 064 & Qui 050391 & $1 / 2$ & 781 & $\mathrm{CP}$ & 0202 & Lisboa & 0 pronunciamento do Porto I & $\begin{array}{l}\text { Os regimentos de caçadores } 9 \text { e de infantaria } 10 \text {, juntamente } \\
\text { com a maior }\end{array}$ & * \\
\hline 17 & 180 & Seg 290691 & $1 / 2$ & 781 & & $\mathrm{~s} / \mathrm{d}$ & & Acerca das formas de governo I & $\begin{array}{l}\text { Ouso considerar-me num satisfatório estado de imparcialidade } \\
\text { para o fim de entrar sem escrúpulos }\end{array}$ & \\
\hline 17 & 182 & Qua 010791 & $1 / 2$ & 812 & & $s / d$ & & Acerca das formas de governo II & $\begin{array}{l}\text { Querem uma prova de quanto é indiferente a denominação de } \\
\text { monárquico ou a denominação de }\end{array}$ & \\
\hline 17 & 184 & Sex 030791 & $1 / 2$ & 781 & & $S / d$ & & Acerca das formas de governo III & $\begin{array}{l}0 \text { ex-imperador do Brasil, recentemente interrogado em Cannes } \\
\text { pelo correspondente de um periódico }\end{array}$ & \\
\hline 17 & 205 & Sex 240791 & 1 & 67 & JL & 010691 & & Jornal de um lisboeta & $\begin{array}{l}\text { Reabertura do parlamento e do teatro da Rua dos condes. [No } \\
\text { parlamento, peça }\end{array}$ & * \\
\hline 17 & 208 & Seg 270791 & $1 / 2$ & 781 & $\mathrm{JL}$ & 050691 & & Jornal de um lisboeta & $\begin{array}{l}\text { Morreu ontem Ângelo Frandoni. Era italiano. Veio para Lisboa } \\
\text { muito moço e faleceu com }\end{array}$ & * \\
\hline 17 & 215 & Seg 030891 & 1 & 78 & $\mathrm{JL}$ & 0706 & & Jornal de um lisboeta & $\begin{array}{l}\text { Votado na câmara dos deputados por } 100 \text { votos contra } 5 \text { o novo } \\
\text { tratado com a Inglaterra }\end{array}$ & * \\
\hline 17 & 217 & Qua 050891 & 1 & 67 & $\mathrm{JL}$ & 1406 & & Jornal de um lisboeta & $\begin{array}{l}\text { Ontem e hoje, corridas de cavalos no hipódromo de Belém. Na } \\
\text { primeira corrida de ontem }\end{array}$ & * \\
\hline 17 & 229 & Seg 170891 & 1 & 8 & $\mathrm{JL}$ & 1506 & & Jornal de um lisboeta & $\begin{array}{l}\text { Na sessão do dia } 10 \text {, na câmara dos deputados, Ferreira de } \\
\text { Almeida manda para a mesa }\end{array}$ & * \\
\hline 17 & 236 & Seg 240891 & 1 & 78 & $\mathrm{JL}$ & 1706 & & Jornal de um lisboeta & $\begin{array}{l}\text { Sir William Gordon Cumming era um dos dez ou doze clubman da } \\
\text { roda Íntima e habitual }\end{array}$ & \\
\hline 17 & 241 & Sab 290891 & 1 & 6 & $\mathrm{JL}$ & 1806 & & Jornal de um lisboeta & $\begin{array}{l}\text { Relendo a nota de ontem sobre o processo Gordon Cumming, uma } \\
\text { cousa me regozija: }\end{array}$ & \\
\hline 17 & 243 & Seg 310891 & $1 / 2$ & 81 & $\mathrm{JL}$ & 2406 & & Jornal de um lisboeta & $\begin{array}{l}\text { Retificação. A Companhia dos Caminhos de Ferro do Norte e } \\
\text { Leste não reelegeu completamente }\end{array}$ & * \\
\hline 17 & 244 & Ter 010991 & 1 & 56 & $\mathrm{JL}$ & 2906 & & Jornal de um lisboeta & $\begin{array}{l}\text { Ontem, delicioso jantar de poucos talheres, na linda casa do } \\
\text { Monte-Estoril, que os condes }\end{array}$ & * \\
\hline 17 & 247 & Sex 040991 & 1 & 56 & $\mathrm{JL}$ & 9707 & $\begin{array}{l}\text { Caldas da } \\
\text { Rainha }\end{array}$ & Jornal de um lisboeta & $\begin{array}{l}\text { Ai que saudades da minha rica jornada antiga das Caldas! Um } \\
\text { dia inteiro de calor }\end{array}$ & * \\
\hline 17 & 249 & Dom 060991 & 1 & 78 & $\mathrm{JL}$ & 1007 & & Jornal de um lisboeta & $\begin{array}{l}\text { Um encanto a natureza, nesta região privilegiada a mais bela } \\
\text { de Portugal. [Ir pescar }\end{array}$ & * \\
\hline 17 & 250 & Seg 070991 & 1 & 7 & $\mathrm{JL}$ & 1007 & & Jornal de um lisboeta & $\begin{array}{l}0 \text { formidável exército castelhano, que pouco depois se avistou } \\
\text { subindo de Leiria }\end{array}$ & * \\
\hline 17 & 251 & Ter 080991 & 1 & 4 & $\mathrm{JL}$ & 1007 & & Jornal de um lisboeta & $\begin{array}{l}\text { Conta ainda Fernam Lopes - e vou já fechar este perigoso } \\
\text { calhamaço, porque não }\end{array}$ & * \\
\hline 17 & 252 & Qua 090991 & $1 / 2$ & 812 & $\mathrm{JL}$ & 1207 & & Jornal de um lisboeta & $\begin{array}{l}\text { Grande desfile de senhoras das oito às dez horas da manhã e } \\
\text { das duas às cinco da tarde }\end{array}$ & * \\
\hline 17 & 254 & Sex 110991 & 2 & 12 & $\mathrm{JL}$ & 1607 & $\begin{array}{l}\text { Caldas da } \\
\text { Rainha }\end{array}$ & Jornal de um lisboeta & $\begin{array}{l}\text { Acabo de visitar a fábrica das faianças, organizada a cinco } \\
\text { anos por iniciativa de }\end{array}$ & \\
\hline 17 & 256 & Dom 130991 & 1 & 78 & $\mathrm{JL}$ & 1607 & $\begin{array}{l}\text { Caldas da } \\
\text { Rainha }\end{array}$ & Jornal de um lisboeta & $\begin{array}{l}\text { Os serviços em pó de pedra, no tipo usual da louça inglesa } \\
\text { não chegaram ainda }\end{array}$ & \\
\hline 17 & 259 & Qua 160991 & 2 & 23 & $\mathrm{JL}$ & 1607 & $\begin{array}{l}\text { Caldas da } \\
\text { Rainha }\end{array}$ & Jornal de um lisboeta & $\begin{array}{l}\text { Na escola industrial anexa à fábrica está montado um } \\
\text { laboratório para as análises }\end{array}$ & \\
\hline 17 & 264 & Seg 210991 & 1 & 78 & $\mathrm{JL}$ & 1907 & Lisboa & Jornal de um lisboeta & $\begin{array}{l}\text { Venho de acompanhar ao cemitério dos Prazeres o enterro da } \\
\text { condessa Daupias, com a }\end{array}$ & \\
\hline- & - & - & - & - & - & - & - & - & & - \\
\hline 18 & 240 & Dom 280892 & 1 & 1234 & $\mathrm{CP}$ & 0606 & Madrid & Siestas de Madrid & $\begin{array}{l}\text { 0 Sr. Navarro Reverier, sub-secretário de estado, deputado da } \\
\text { nação, secretário da comissão diretora das }\end{array}$ & \\
\hline
\end{tabular}




\begin{tabular}{|c|c|c|c|c|c|c|c|c|c|c|}
\hline ANO & NUM & DAT $\mathbf{P}$ & PAG & COL & $\mathbf{S}$ & DAT E & LOC E & TÍTULO OU ASSUNTO & PALAVRAS INICIAIS & \\
\hline 18 & 241 & Seg 290892 & 1 & 567 & $\mathrm{CP}$ & 0706 & Madrid & Siestas de Madrid & $\begin{array}{l}\text { Domingo passado, grande e extraordinária corrida de touros no } \\
\text { "redondel" de Madrid. Lagartijo, que conta }\end{array}$ & \\
\hline 18 & 242 & Ter 300892 & 1 & 678 & $\mathrm{CP}$ & 0906 & Madrid & Siestas de Madrid & $\begin{array}{l}\text { Ontem à noite, ao jantar no Nuovo Club, o conde de E... C..., } \\
\text { no momento feliz de atacar o seu prato de }\end{array}$ & \\
\hline 18 & 261 & Dom 180992 & 1 & 45 & $\mathrm{CP}$ & 1006 & Madrid & Siestas de Madrid & $\begin{array}{l}\text { Uma das particularidades do mundanismo madrileno é a } \\
\text { sociedade }(\ldots) \text {. Em Paris e em Londres, os grandes }\end{array}$ & \\
\hline 18 & 263 & Ter 200992 & 1 & 78 & $\mathrm{CP}$ & 1206 & Madrid & Siestas de Madrid & $\begin{array}{l}\text { Pensar que de um jogo destes pode a gente sair, como qualquer } \\
\text { destes robustos e amestrados rapazes, sem }\end{array}$ & \\
\hline 18 & 270 & Ter 270992 & 1 & 6 & CP & 1206 & Madrid & Siestas de Madrid & $\begin{array}{l}\text { A Alemanha e a Áustria, onde a ginástica é naturalmente } \\
\text { obrigatória em todos os estabelecimentos de educação }\end{array}$ & \\
\hline- & - & & - & - & - & - & - & - & - & - \\
\hline 20 & 227 & Qui 160894 & $1 / 2$ & 7812 & & $\mathrm{~s} / \mathrm{d}$ & & Santo Antonio de Lisboa & $\begin{array}{l}\text { Excelentíssima comissão, queridos compatriotas, amados } \\
\text { irmãos. - Dicere non audeo, tacere non possum, disse }\end{array}$ & * \\
\hline 20 & 228 & Sex 170894 & $1 / 2$ & 81 & & $\mathrm{~s} / \mathrm{d}$ & & Santo Antonio de Lisboa & $\begin{array}{l}\text { No momento em que vos falo, ao cabo de tantos anos de } \\
\text { sossego, in pulcheridune parcis, que tendes vos feito, }\end{array}$ & * \\
\hline 20 & 229 & Sab 180894 & 1 & 78 & & $S / d$ & & Santo Antonio de Lisboa & $\begin{array}{l}\text { Uma vez, porém, que a minha festa deixou de ser a espontânea } \\
\text { festa do povo para vir a ser o festival que a }\end{array}$ & * \\
\hline- & - & & - & - & - & - & - & - & - & - \\
\hline 21 & 016 & Qua 160195 & 1 & 78 & IM & 151194 & & Impressões & $\begin{array}{l}\text { Partiram as andorinhas, abandonando altivamente ao sudoeste, } \\
\text { à chuva e ao frio os ninhos feitos }\end{array}$ & \\
\hline 21 & 017 & Qui 170195 & $1 / 2$ & 81 & IM & $\mathrm{s} / \mathrm{d}$ & & Impressões & $\begin{array}{l}\text { Ninguém jamais possuiu em mais alto grau essa perfeição do } \\
\text { homem ideal, a que Herbert spencer chama a }\end{array}$ & \\
\hline 21 & 018 & Sex 180195 & 1 & 78 & IM & $\mathrm{s} / \mathrm{d}$ & & Impressões & $\begin{array}{l}\text { A sua língua, ligeira, impetuosa, muitas vezes singularmente } \\
\text { persuasiva, carece de consistência estrutural }\end{array}$ & \\
\hline 21 & 030 & Qua 300195 & $1 / 2$ & 781 & IM & 1294 & & Impressões & $\begin{array}{l}\text { Na câmara dos Srs. deputados houve uma sessão horrivelmente } \\
\text { tumultuosa, à qual se seguiram quatro ou cinco }\end{array}$ & * \\
\hline 21 & 085 & Ter 260395 & 1 & 78 & & $\mathrm{~s} / \mathrm{d}$ & & A arte portuguesa: Silva Porto & $\begin{array}{l}\text { A pintura de paisagem era em Portugal uma arte de convenção, } \\
\text { tendo por sujeito imitar a natureza em sentido }\end{array}$ & \\
\hline 21 & 104 & Dom 140495 & $1 / 2$ & 8123 & & $\mathrm{~s} / \mathrm{d}$ & & João de Deus: 0 portuguesismo e o amor & $\begin{array}{l}\text { Toda a vida humana, toda a atividade do homem se resume } \\
\text { nisto: - Sentimentos, idéias, ações. }\end{array}$ & * \\
\hline 21 & 164 & Qui 130695 & 1 & 56 & IP & 1505 & Lisboa & Impressões portuguesas & $\begin{array}{l}0 \text { grande banquete oferecido ontem ao novo ministro do Brasil, } \\
\text { no teatro de são carlos, foi uma solenidade }\end{array}$ & * \\
\hline 21 & 168 & Seg 170695 & 1 & 56 & IP & 0105 & Lisboa & Impressões portuguesas & $\begin{array}{l}\text { Entramos no mais lindo mês do ano, o mês da páscoa rosada, o } \\
\text { florido mês de Maria. Em nossas latitudes, }\end{array}$ & * \\
\hline 21 & 176 & Ter 250695 & 1 & 67 & IP & 0905 & Lisboa & Impressões portuguesas & $\begin{array}{l}\text { Ontem, celebração da missa dos trinta dias por alma de } \\
\text { Pinheiro Chagas - mais um que partiu para não voltar }\end{array}$ & \\
\hline 21 & 180 & Sab 290695 & 1 & 78 & IP & 1005 & Lisboa & Impressões portuguesas & $\begin{array}{l}\text { Principia-se a debater nos periódicos de hoje, com anuência e } \\
\text { aplauso de alguns deles, esta singela idéia }\end{array}$ & * \\
\hline 21 & 187 & Sab 060795 & $1 / 2$ & 81 & IP & 2005 & Lisboa & Impressões portuguesas & $\begin{array}{l}\text { Notável caso de chantage registrado nos jornais de ontem e de } \\
\text { anteontem. [Carlos de Mello professor de }\end{array}$ & * \\
\hline 21 & 233 & Qua 210895 & 2 & 678 & & $\mathrm{~s} / \mathrm{d}$ & & Os monumentos arquit. em Portugal I & $\begin{array}{l}\text { Durante os dias triunfantes da Renascença e ainda através da } \\
\text { escura idade média, tão insuficientemente }\end{array}$ & \\
\hline 21 & 240 & Qua 280895 & 2 & 34 & & $\mathrm{~s} / \mathrm{d}$ & & Os monumentos arquit. em Portugal II & $\begin{array}{l}\text { Levaria muito tempo e seria excessivamente triste enumerar } \\
\text { todos os atentados de que tem sido e continuam }\end{array}$ & \\
\hline 21 & 245 & Ter 030995 & 1 & 56 & & $\mathrm{~s} / \mathrm{d}$ & & Os mon. arquit. em Portugal II cont. & $\begin{array}{l}\text { Pela entrada principal da igreja, à semelhança do que sucede } \\
\text { em grande parte das igrejas góticas, desciam-se }\end{array}$ & \\
\hline 21 & 300 & Sab 261095 & 1 & 78 & CP & $\mathrm{s} / \mathrm{d}$ & & Culto da arte & $\begin{array}{l}\text { Pelo número e pelo quilate das mutilações, deturpações e } \\
\text { superfetações, inteiramente arbitrárias e }\end{array}$ & \\
\hline 21 & 301 & Seg 281095 & 1 & 678 & CP & $s / d$ & & Culto da arte & $\begin{array}{l}\text { Igualmente se desempenham por espírito de inconcebível } \\
\text { estrangeirismo os produtos primorosos de algumas das }\end{array}$ & \\
\hline 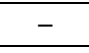 & 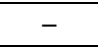 & - & - & 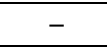 & - & - & - & - & & - \\
\hline 28 & 265 & Dom 220901 & 2 & 6 & & & & A morte de Eduardo Prado & $\begin{array}{l}\text { A morte deste nobilíssimo brasileiro foi conhecida em Lisboa } \\
\text { no dia } 31 \text { do mês passado, por um telegrama enviado }\end{array}$ & * \\
\hline 28 & 271 & Sab 280901 & $1 / 2$ & 81 & $\mathrm{CP}$ & 0801 & Lisboa & A questão religiosa I & $\begin{array}{l}\text { A religião, nas sociedades em que deixa de ter inviolável } \\
\text { sacrário e por cidadela inexpugnável a crença }\end{array}$ & * \\
\hline 28 & 283 & Qui 031001 & $1 / 2$ & 812 & $\mathrm{CP}$ & 0801 & Lisboa & A questão religiosa II & $\begin{array}{l}\text { O conhecido caso Calmon, - história íntima, naturalmente } \\
\text { confusa, bastante vaga, de uma senhora maior de }\end{array}$ & \\
\hline
\end{tabular}




\begin{tabular}{|c|c|c|c|c|c|c|c|c|c|c|}
\hline ANO & NUM & DAT $\mathbf{P}$ & PAG & COL & $\mathbf{S}$ & DAT E & LOC E & TÍTULO OU ASSUNTO & PALAVRAS INICIAIS & \\
\hline 28 & 283 & Qui 101001 & $1 / 2$ & 812 & $\mathrm{CP}$ & 0801 & Lisboa & A questão religiosa III & $\begin{array}{l}\text { A abolição dos conventos - medida política destinada a } \\
\text { improvisar bens nacionais e a enriquecer a vitoriosa }\end{array}$ & * \\
\hline 28 & 304 & Qui 311001 & 1 & $1 / 8$ & & 110901 & & No mar - Sensações de viagem & $\begin{array}{l}\text { Passamos ontem o estreito de Gilbraltar, e, a bordo de um dos } \\
\text { vapores da Deutsche Ost-Afrika }\end{array}$ & * \\
\hline- & - & - & - & - & - & - & - & - & - & - \\
\hline 31 & 332 & Dom 271104 & & 6 & & & & Discurso de R. Ortigão (Suplemento) & $\begin{array}{l}\text { Foi na cidade do Porto, em Vila Nova de Gaia, no domingo } 30 \\
\text { de outubro, que se inaugurou a estátua magnífica esculpida }\end{array}$ & * \\
\hline- & - & - & - & - & - & - & - & - & rem & - \\
\hline 34 & 044 & Qui 130208 & $2 / 3$ & $\mathrm{col}^{2}$ & & & & Sua majestade a rainha & $\begin{array}{l}\text { Há nove anos que uma princesa de Orléans se casava em Lisboa } \\
\text { com um príncipe de Bragança, e nunca brasões }\end{array}$ & \\
\hline 34 & 071 & Qua 110308 & 1 & $1 / 8$ & $\mathrm{CP}$ & 090208 & Lisboa & Rei D. Carlos, o martirizado & $\begin{array}{l}\text { "Tenho grandes imperfeições como homem e como rei. Os meus } \\
\text { defeitos procedem de duas causas: primeira }\end{array}$ & \\
\hline 34 & 362 & Dom 271208 & $1 / 2$ & $\begin{array}{c}4567 \\
81\end{array}$ & & & & A morte de Rosinha & $\begin{array}{l}\text { Minha amiguinha adorada. - Ontem à noite, enquanto a tua mamã } \\
\text { bordava à luz do candeeiro uma touca }\end{array}$ & \\
\hline- & - & - & - & - & - & - & - & & & - \\
\hline 35 & 036 & Sex 050209 & 1 & 1 & & & & A tragédia do Terreiro do Paço & $\begin{array}{l}\text { Parece que foi ontem, e há um ano! [Era um dos mais lindos } \\
\text { dias do doce inverno de Lisboa, somente }\end{array}$ & \\
\hline 35 & 041 & Qua 100209 & 1 & 1234 & & $s / d$ & & Sicília (Sensações de arqu. e arte I) & $\begin{array}{l}\text { Há sete anos que, por fim do mês de setembro, eu percorria a } \\
\text { Sicília, desembarcando em Palermo, dando volta }\end{array}$ & \\
\hline 35 & 048 & Qua 170209 & 1 & 12 & & $\mathrm{~s} / \mathrm{d}$ & & Sicília (Sensações de arte II) & $\begin{array}{l}\text { Para ter noção do que era, fora dos seus grandes monumentos, } \\
\text { a arte móbil da Sicília durante a colonização }\end{array}$ & \\
\hline 35 & 107 & Sab 170409 & 1 & 1234 & & & & Uma conferência & $\begin{array}{l}\text { A conferência que se vai ler foi proferida há três dias, e } \\
\text { ouvida com expressiva benevolência, perante uma }\end{array}$ & * \\
\hline- & - & - & - & - & - & - & - & & - & - \\
\hline 37 & 037 & Ter 070211 & 1 & $1 \mathrm{a} 6$ & $\mathrm{CP}$ & 070111 & Lisboa & A revolução de outubro & $\begin{array}{l}\text { Victor Hugo, regressando a Paris do exílio de Guernessey, } \\
\text { depois da queda do império e da proclamação }\end{array}$ & \\
\hline 37 & 073 & Ter 140311 & 1 & 1234 & $\mathrm{CP}$ & 150211 & Lisboa & Quadro histórico a partir de 1640 & $\begin{array}{l}\text { A restauração de } 1640 \text { restituiu à nação portuguesa a sua } \\
\text { autonomia política, mas não restituiu com }\end{array}$ & \\
\hline 37 & 131 & Qui 110511 & $1 / 2$ & 7812 & $\mathrm{CP}$ & 0311 & & A república portuguesa & $\begin{array}{l}\text { Debalde a pavorosa hidra da reação, por todo Portugal, e por } \\
\text { boa parte do Brasil segundo rezam os papéis, }\end{array}$ & \\
\hline 37 & 194 & Qui 130711 & 1 & 1234 & $\mathrm{CP}$ & 0511 & Paris & Em trânsito & $\begin{array}{l}\text { Fazendo parte de um júri de arte nomeado pelo Governo Federal } \\
\text { Suíço e devendo em desempenho dessa missão }\end{array}$ & \\
\hline 37 & 247 & Seg 040911 & 1 & $1 \mathrm{a} 6$ & $\mathrm{CP}$ & 0711 & Paris & Breve recapitulação & $\begin{array}{l}\text { Um dos publicistas da República Portuguesa formulava, mui } \\
\text { judiciosamente, poucos dias depois da }\end{array}$ & \\
\hline- & - & - & - & - & - & - & - & & - & - \\
\hline 38 & 046 & Qui 150212 & 1 & 12 & $\mathrm{CP}$ & 1912 & Paris & Bom ano! & $\begin{array}{l}\text { Acabamos de entrar, nós portugueses, no ano } 2 \text { da República. } \\
\text { Felizes entradas e muito boas festas, como }\end{array}$ & \\
\hline 38 & 063 & Seg 040312 & 1 & 123 & $\mathrm{CP}$ & 1912 & Paris & 0 natalício da república & $\begin{array}{l}\text { Nas regiões oficiais portuguesas, das Quais se baniu como } \\
\text { reacionária a tradição cristã, foi o natal da }\end{array}$ & \\
\hline 38 & 078 & Seg 180312 & 1 & 123 & $\mathrm{CP}$ & 290112 & Paris & 0 figurino francês $\mathrm{I}$ & $\begin{array}{l}\text { Quer rindo, quer chorando, de qualquer ponto de vista e em } \\
\text { qualquer disposição de espírito, em que a }\end{array}$ & \\
\hline 38 & 183 & Seg 010712 & $1 / 2$ & 7812 & $\mathrm{CP}$ & $S / d$ & & Experiência feita & $\begin{array}{l}\text { A República Portuguesa continua ao mundo o mais espantosos e } \\
\text { inacreditável espetáculo: - existe! [Perante }\end{array}$ & \\
\hline 38 & 184 & Ter 020712 & $1 / 2$ & 7812 & $\mathrm{CP}$ & $\mathrm{s} / \mathrm{d}$ & & Continuação da carta anterior & $\begin{array}{l}\text { Lisboa inteira acha-se convertida num enorme teatro sem teto } \\
\text { em que o espetáculo novo de uma democracia }\end{array}$ & \\
\hline 38 & 202 & Sab 200712 & $1 / 2$ & 7812 & $\mathrm{CP}$ & $\mathrm{s} / \mathrm{d}$ & & A raça & $\begin{array}{l}\text { Logo a seguir à proclamação da República e à publicação das } \\
\text { suas primeiras leis, em Lisboa, o Times, num }\end{array}$ & \\
\hline 38 & 203 & Dom 210712 & 5 & 78 & $\mathrm{CP}$ & $\mathrm{s} / \mathrm{d}$ & & Continuação da carta anterior & $\begin{array}{l}\text { Em Portugal, onde nunca se chegou a formar um museu } \\
\text { etnológico com a representação integral das nossas }\end{array}$ & * \\
\hline 38 & 364 & Dom 291212 & 5 & 78 & $\mathrm{CP}$ & 221112 & Paris & Embaixadores de letras na Europa & $\begin{array}{l}\text { A crônica das idéias, o mais precioso título da glória de um } \\
\text { povo, tem, em contraposição a datas funestas }\end{array}$ & \\
\hline- & - & - & - & - & - & - & - & - & - & - \\
\hline 39 & 001 & Qua 010113 & 5 & 78 & $\mathrm{CP}$ & 221112 & Paris & Continuação da carta anterior & $\begin{array}{l}\text { No século XVIII, formação do primeiro agrupamento literário } \\
\text { do Brasil pela criaçâo da chamada Escola de }\end{array}$ & \\
\hline 39 & 013 & Seg 130113 & $1 / 2$ & 781 & & 1912 & Paris & Como nós éramos...Como eles são & $\begin{array}{l}\text { Como os governos imorais desmoralizam a gente! Como } \\
\text { rapidamente eles quebram as energias e corrompem }\end{array}$ & \\
\hline
\end{tabular}

2 São as seguintes as colunas: 2345678123 


\begin{tabular}{|c|c|c|c|c|c|c|c|c|c|c|}
\hline ANO & NUM & DAT $\mathbf{P}$ & PAG & COL & $\mathbf{s}$ & DAT E & LOC E & TÍTULO OU ASSUNTO & PALAVRAS INICIAIS & \\
\hline 39 & 038 & Sex 070213 & $1 / 2$ & 781 & & 210113 & Paris & 0 rei D. Carlos & $\begin{array}{l}\text { A data de } 1 \text { de fevereiro de } 1908 \text {, que este jornal } \\
\text { piedosamente comemora, é a mais negra de toda a nossa }\end{array}$ & \\
\hline 39 & 051 & Qui 200213 & 1 & 7812 & & 150113 & Paris & Uma sessão parlamentar & $\begin{array}{l}\text { Incidente hilariantemente molieresco e castiçamente } \\
\text { pourceaugnáquico na assembléia do Senado. Nele tem o }\end{array}$ & \\
\hline 39 & 155 & Qua 040613 & 1 & 78 & & 0113 & Paris & Uma lei & $\begin{array}{l}\text { A mim! A mim, ó manes da extinta chacota lusitana! A mim } \\
\text { Mendes Enxudia e Bertoldinho! A mim Vicente }\end{array}$ & \\
\hline 39 & 239 & Qua 270813 & $1 / 2$ & 7812 & & 300713 & Evian & A nova Lisboa & $\begin{array}{l}\text { Em Lisboa, que saudosamente eu voltara a ver depois de dois } \\
\text { anos de ausência, e onde acabo de passar quatro }\end{array}$ & \\
\hline- & - & & - & - & - & - & - & - & - & - \\
\hline 41 & 283 & Dom 171015 & 2 & $1 / 8$ & & & & $\begin{array}{l}\text { Republicação de Embaixadores de letras na } \\
\text { Europa }\end{array}$ & $\begin{array}{l}\text { A crônica das idéias, o mais precioso título da glória de um } \\
\text { povo, tem, em contraposição a datas funestas }\end{array}$ & \\
\hline
\end{tabular}

Para a elaboração do presente quadro foram consultadas as coleções da Gazeta de Notícias:

1. Em microfilmes da Biblioteca Nacional do Rio de Janeiro: de 1875 a 1877 no arquivo da Universidade de Campinas; de 1878 a 1895, parte deles consultado em coleções particulares e parte na biblioteca da Faculdade de Filosofia Letras e Ciências Humanas da Universidade de São Paulo.

2. Diretamente das páginas dos jornais: de 1896 a 1915 na Biblioteca John F. Kennedy. 


\section{3 - Relação das colaborações publicadas na Gazeta de Notícias e recolhidas em livros do autor*}

190178: As farpas I, pág. 71, com o título de "O natal minhoto - O presépio - A consoada - A ceia de família", sem indicação de data.

010278: Costumes e perfis, pág. 177, com o título de "Sua Majestade o Sr. D. Luís I" e a informação dos editores ter sido publicado anteriormente em O Ocidente, vol. I, № 2, de 15 de janeiro de 1878.

030378: As farpas VIII, pág. 230, com o título de "A crítica de uma senhora às teorias das Farpas sobre a educação das mulheres", com data de janeiro de 1878.

250678: As farpas III, pág. 73, com o título de "Caldas Aulete", com a data de maio, 1879. (provável erro de data)

170878: Notas de viagem, pág. 8, sem título e datado de Paris, 8 de julho. Na Gazeta de Notícias a data é de 18 de julho.

210878: Idem, pág. 19, sem título e datado de Paris, 21 de julho, a mesma da Gazeta de Notícias.

290878: Idem, pág. 31, com o título de "Alguns sucessos" e sem indicação de data.

030978: Idem, pág. 43, sem título e datado de Paris, 21 de julho, a mesma data da Gazeta de Notícias.

100978: Idem, pág. 57, sem título e datado de Paris, 26 de julho, como na Gazeta de Notícias.

140978: Idem, pág. 69, sem título e datado de Paris, 10 de agosto, como na Gazeta de Notícias.

170978: Idem, pág. 79, sem título e datado de Paris, 13 de agosto, como na Gazeta de Notícias.mm

200978: Idem, pág. 93, sem título e datado de Paris, 18 de agosto, como na Gazeta de Notícias.

260978: Idem, pág. 105, como titulo de "A exposição" e sem indicação de data.

\footnotetext{
* Os números à esquerda indicam a data de publicação na Gazeta de Notícias; o texto à direita os volumes em que foram recolhidas, as colaborações além de informações consideradas oportunas. (Ex.: $190178=19$ de janeiro de 1878)
} 
121078: Idem, pág. 119, com o título de "A exposição de pinturas" e sem indicação de data.

251078: Idem, pág. 132. Continuação da carta anterior.

161178: Idem, pág. 145, como o título de "Os impressionistas" e sem indicação de data.

231178: Idem, pág. 157, com o título de "As nações artísticas" e sem indicação de data.

251178: Idem, pág. 168. Continuação da carta anterior.

271178: Idem, pág. 175. Continuação da carta anterior.

071278: Idem, pág. 185, como título de "A mobília nos países expositores", sem indicação de data.

151278: Idem, pág. 199. com o título de "A mobília futura" e sem indicação de data.

191278: Idem, pág. 215, com o título de "O ensino" e sem indicação de data.

030179: Idem, pág. 227, com o título de “O museu pedagógico" e sem indicação de data.

100179: Idem, pág. 247, com o título de "Através dos congressos" e sem indicação de data.

120179: Idem, pág. 256. continuação da carta anterior.

050279: Idem, pág. 269, com o título de "A antropologia na exposição" e sem indicação de data.

140279: Idem, pág. 279. Continuação da carta anterior.

070379: Arte portuguesa III, pág. 7, como o título de "O concurso de pintura na Academia de Belas Artes", com a mesma data da Gazeta de Notícias e informação dos editores de ter sido publicado no Diário da Manhã, de 14 de fevereiro de 1879.

150379: Figuras e questões literárias II, p. 229, com o título de "A viagem à roda da Parvónia" e a informação do editores ter sido publicado no Diário da Manhã, de 5 de abril de 1879. Trata-se da segunda parte da carta cujo primeiro assunto versou sobre a queda da Torre dos Jerônimos.

130479: As farpas II, pág. 233, com o título de "De agradecimento à Corte" e sem indicação de data. 
260579: As farpas III, pág. 279, com o título de "O penteeiro da Rua da Almada" e datado de 1882.

280679: As farpas VII, pág. 281, com o título de "Aspectos do verão - A feira das Amoreiras - Ainda os touros", sem indicação de data.

240879: As farpas II, pág. 133, com o título de "A monsenhor" e sem indicação de data.

250979: Arte portuguesa III, pág. 35, com o título de "Silva Porto" e a informação dos editores de ter sido publicado no Diário da Manhã, de 15 de outubro de 1879.

161079: As farpas I, pág. 131, com um sumário em lugar de título e datado do Porto, julho de 1883.

251079: As farpas I, pág. 234, com algumas modificações.

051279: Arte portuguesa III, pág. 47, com o título de "Cifka" e a informação dos editores ter sido publicado no Diário da Manhã, de 30 de dezembro de 1879.

200580: Arte portuguesa III, pág. 69, com o título de "Carolus Duran, Silva Porto e Columbano" e a informação dos editores ter sido publicado anteriormente na Gazeta de Notícias. O texto é datado de Lisboa, 28 de abril de 1880, como na Gazeta de Notícias. A carta do jornal é antecedida de outra matéria.

290580: Arte portuguesa III, pág. 77, com o título de "A exposição de belas artes" e a informação dos editores ter sido publicado no Diário da Manhã de 23 de junho de 1880.

141180: Figuras e questões literárias II, pág. 261, com o título de "Gustavo Diercks e Ladislau Micckiewicz" e a informação dos editores de ter sido publicado no Diário da Manhã de 10 de dezembro de 1880. Foi suprimida uma longa introdução (11 parágrafos).

171280: As farpas IX, pág. 135, com o título de "Projeto de um monumento a Alexandre Herculano - Rápido paralelo do Catão de Vale de Lobos e do Catão de Utica".

270281: As farpas $X$, pág. 155, com um cabeçalho de assunto principiado por "A sociedade de Geografia". 
090381: As farpas III, pág. 221, com o título de "Garret" e data de fevereiro de 1882, sendo na Gazeta de Notícias a data de emissão: Lisboa, 5 de fevereiro.

230381: As farpas IV, p. 299, com o título de "Os nossos primeiros estadistas", datado de Fevereiro, 1881 e com algumas alterações.

290381: Idem, pág. 304, continuação do texto.

310381: Idem, pág. 309, conclusão do texto.

080581: Costumes e perfis, pág. 243, com o título de "Borghi Mamo" e a informação dos editores ter sido publicado em Ribaltas e Gambiarras, no 27, Lisboa, 5 de junho de 1881.

040681: Costumes e perfis, pág. 211, com o título de "O duque de Ávilla" e a informação dos editores ter sido publicado em Ribaltas e Gambiarras, no - 36, Lisboa, 7 de agosto de 1881. Houve adaptação para a publicação neste órgão. Ex.: Foi sepultado esta tarde [GN] ; Foi sepultado no dia 5 de maio [RG], (data da emissão da carta).

160781: Pela terra alheia, pág.35, com o mesmo título da Gazeta de Notícias. O capítulo I ainda não foi encontrado no jornal.

200781: Idem ao anterior, pág. 48.

210781: Idem ao anterior, pág. 65.

290881: Idem ao anterior, pág. 79.

020981: Idem ao anterior, pág. 93.

090981: Idem ao anterior, pág. 109.

131081: Figuras e questões literárias II, com o título de "Os dicionários portugueses" e a informação dos editores ter sido publicado no Diário da Manhã, de 5 de novembro de 1881.

041181: As farpas I, pág. 271, com o título de "Na Trafaria - Cena da borda d'água".

201181: Costumes e perfis, pág. 195, com o título de "O patrão Joaquim Lopes" e a informação dos editores ter sido publicado na Revista Ilustrada, ํo 18, de 31 de dezembro de 1890. É preciso a confirmação de tratar-se da mesma matéria, pois os começos não coincidem.

281181: As farpas III, pág. 267, com o título de "Ortego e André Gill", datado de outubro, 1881. 
020182: As farpas VIII, pág. 245, com o título de "A educação militar - Seus efeitos na constituição do caráter".

040182: As farpas VIII, pág. 263, com o título de "O elemento galante - Sua ação na formação dos caracteres - Seus efeitos do lado delas e do lado deles".

230182: As farpas V, pág. 163, com o título de "A festa do Natal - A festa das crianças e a história de uma que se não divertiu".

300182: As farpas $V$, pág. 171: conclusão da carta anterior.

010282: As farpas IV, pág. 167, com o título de "Solene sessão inaugural", datado de Janeiro, 1882.

130282: As farpas VIII, pág. 305, com o título de "Os colegiais militares". Provavelmente na Gazeta de Notícias haja outros assuntos, na carta.

080382: As farpas III, pág. 205, com o título de "O bispo de Viseu", datado de fevereiro, 1882. Deve haver na carta da Gazeta de Notícias um assunto anterior, pois não coincidem os começos.

250382: As farpas IV, pág. 279, com o título de "A carta", datado de fevereiro de 1882.

070482: As farpas IX, pág. 65, com o título de "A sociedade de instrução do Porto - Seu programa, seus fins, sua influência na arte", datada de Fevereiro, 1882.

100482: As farpas $V$, pág. 119, com o título de "Um desacato - Meios propostos para aplacar a divindade".

150482: As farpas VIII, pág. 273, com o título de "A educação religiosa Episódios da desobriga", com data de março, 1882.

280482: As farpas IX, pág. 201, com um cabeçalho de assunto principiado por "A literatura dos curiosos" e datado de Março, 1882.

140582: As farpas III, pág. 215 ou Figuras e questões literárias II, pág. 73. Não há coincidências dos começos, há incoerências de datas, podendo tratar-se de adaptações, ou até mesmo texto inédito.

260682: As farpas VII, pág. 303, com o título de "A estátua do Marquês de Pombal", datado de Maio, 1882.

180782: As farpas V, pág. 195, com o título de "As comunidades religiosas - A companhia de Jesus". 
161082: As farpas I, pág. 95, com o título de "Romagem à Senhora do Monte Sameiro - Cenas de Braga", datada de setembro, 1882.

201082: As farpas III, pág. 235, com o título de "Antonio Rodrigues Sampaio", datado de Setembro de 1882.

231082: Idem, pág. 247, continuação da carta anterior.

061182: Idem, pág. 256, continuação da carta anterior.

130183: As farpas XV, pág. 231, com o título de "Fausto e jocundo desacato de S. Exa. o Ministro da Justiça por S. Ema. o Núncio de Sua Santidade" , com data de novembro-dezembro de 1882.

140183: Idem, pág. 238, continuação da carta anterior.

030283: As farpas IV, pág. 227, com o título de "Restabelecimento da tribuna". Verificar, pois não coincidem os começos.

190283: As farpas IV, pág. 293, com o título de "O juramento político".

060383: Arte portuguesa III, pág. 87, com o título de "A exposição de quadros Alberto de Oliveira" e a informação dos editores ter sido publicado no Diário da Manhã de 7 de abril de 1883.

210383: As farpas V, pág. 145, com o título de "A morte de um patriarca".

280383: As farpas VIII, pág. 253, com um cabeçalho de assunto principiado por "A educação do povo".

090483: Arte portuguesa III, pág. 113, com o título de "Na morte de Miguel Luppi" e a informação dos editores ter sido publicado em O Fígaro, de 8 a 11 de maio de 1883.

230483: As farpas $X I$, pág. 7, com o título de "A instrução secundária na Câmara dos Deputados". Há esta informação dos editores, no final do texto: "Este estudo de Ramalho Ortigão foi publicado em opúsculo, no Rio de Janeiro, em 1883, com o título de A lei da instrução secundária na Câmara dos Deputados em Portugal.

250483: Idem ao anterior, pág. 19.

280483: Idem ao anterior, pág. 32.

300483: Idem ao anterior, pág. 47.

020583: Idem ao anterior, pág. 59.

190983: Pela terra alheia II, pág. 53, datado de Valparaíso, St. Steamer, Cabine no 19, 5 de agosto de 1883.

210983: Idem, pág. 67, datado de Paris, 10 de agosto de 1883. 
250983: Idem, pág. 83, datado de Aix-la-Chapelle, 14 de agosto de 1883.

270983: Idem, pág. 97, datado de Colônia, 17 de agosto de 1883.

011083: Idem, pág. 113, datado de Wiesbaden, 10 de setembro de 1883.

101083: A Holanda I, pág. 8, com algumas alterações.

151083: Idem, pág. 15, com mudanças nos tempos verbais.

221083: Idem, pág. 25, com pequenas alterações.

231083: Idem, pág. 38.

271083: Idem, pág. 55.

291083: Idem, pág. 62.

311083: Idem, pág. 70, com mudanças nos tempos verbais.

031183: Idem, pág. 78.

181283: Idem, pág. 86.

201286: Idem, pág. 92.

301283: Idem, pág. 100.

030184: Idem, pág. 113. No livro o subtítulo é "Campos e aldeias".

060184: Idem, pág. 123.

300184: Idem, pág. 130.

070284: Idem, pág. 140.

150284: Idem, pág. 147.

230284: As farpas III, pág. 103, datado de janeiro de 1884.

260284: Idem, pág. 112.

010384: Idem, pág. 121.

010484: A Holanda I, pág. 159.

050484: Idem, pág. 166.

090484: Idem, pág. 175, com pequena alteração no início.

110484: Idem, pág. 185.

030584: Idem, pág. 192, com acréscimo no livro.

050584: Idem, pág. 201, com modificações nos tempos verbais.

160584: Idem, pág. 210.

210584: Idem, pág. 218.

230584: Idem, pág. 228.

280584: Idem, pág. 235.

070684: A Holanda II, pág. 10.

170684: Idem, pág. 18. No livro o início é: "Há na Holanda a indústria...". 
220684: Idem, pág. 26.

030784: Idem, pág. 35. No livro "sofá" é trocado por "canapé".

210784: Idem, pág. 43.

030884: Idem, pág. 52. Há um resumo na pág. 48 do livro.

080884: Idem, pág. 60.

200884: Idem, pág. 68.

030984: Idem, pág. 76. No livro o sujeito "Delf" é posposto à oração subordinada.

050984: Idem, pág. 83.

100984: Idem, pág. 95.

110984: Idem, pág. 103. Há supressão de "numa aldeia", no livro.

150984: Idem, pág. 111. Há um resumo acima do parágrafo inicial.

220984: Idem, pág. 119. Há um resumo como cabeçalho.

141084: As farpas I, pág. 141, continuação do texto recolhido à pág. 131, publicado pela Gazeta de Notícias no dia 16 de outubro de 1879.

241084: As farpas I, pág. 151, continuação do texto anterior.

271084: As farpas I, pág.241, com o título de "Espinho, piscina da magistratura - Aspectos das ruas - A batota - O clube".

011184: A Holanda II, pág. 128.

031184: A Holanda II, pág. 144, há resumos nas páginas 135 e 142.

061184: As farpas I, pág. 223, com um cabeçalho de assunto principiado por "S. João da Foz".

051284: As farpas I, pág. 251, com um cabeçalho de assunto principiado por "A Granja, banho particular".

181284: As farpas I, pág. 103, datado de Régua - outubro, 1885.

231284: As farpas I, pág. 121, seqüência do texto anterior.

251284: As farpas I, pág. 114.

040185: Idem, pág. 7, com o título de "Entre o Minho e o Douro", datado de setembro de 1885.

050185: As farpas I, pág. 18, continuação da carta anterior.

080185: As farpas I, pág. 29, continuação da cara anterior.

200185: As farpas IX, pág. 17, com um cabeçalho de assunto principiado por "A nova lei de imprensa".

210185: As farpas IX, pág. 27, continuação. 
220185: Idem, pág. 37, continuação.

270185: Idem, pág. 48, continuação.

070385: As farpas IX, pág. 145, com um cabeçalho de assunto principiado por "A arte satírica", datado de Abril, 1882.

160385: As farpas IX, pág. 157, continuação.

260385: Idem, pág. 171, continuação

280685: As farpas III, pág. 55, datado de maio, 1885.

290685: Idem, pág. 62, conclusão da carta anterior.

180785: A Holanda II, pág. 181. Parece haver alterações substanciais entre os textos do jornal e do livro. É necessário uma pesquisa mais cuidadosa. 170885: Idem, pág. 151. Mesma observação do item anterior.

280885: Idem, pág. 163. Suprimido "neerlandesas", no livro.

290885: Idem, pág. 174.

020985: Idem, pág. 191. No livro o título do capítulo é "A arte".

050985: Idem, pág. 198.

070985: Idem, pág. 203.

080985: Idem, pág. 210.

090985: Idem, pág. 219.

110985: Idem, pág. 225. O capítulo "A cultura intelectual" consta apenas do livro.

170985: John Bull, pág. 43, com um cabeçalho de assunto principiado por "Very improper?". Do livro foi suprimido o parágrafo sobre Elísio Mendes.

180985: John Bull, pág. 59, com resumo como cabeçalho. É o capítulo III do livro.

200985: Idem, pág. 77, também com resumo. É o capítulo IV do livro. Tem 29 páginas no livros. (ver jornal)

270985: Idem, pág. 107, com resumo. Capítulo V do livro.

280985: Idem, pág. 119, com resumo. Capítulo VI do livro.

290985: Idem, pág. 217, com resumo. Capítulo X do livro. Com pequenas alterações.

071085: Idem, pág. 231, com resumo. Capítulo XI do livro.

100186: As farpas I, pág. 46, com um cabeçalho de assunto principiado por "As aldeias minhotas", datado de Janeiro, 1885. 
110186: As farpas I, pág. 53, continuação da carta anterior.

170286: As farpas V, pág. 133.

180286: Idem, pág. 139, seqüência da carta anterior.

190286: Idem, pág. 299, com o título de "Acerca da Semana santa - A caducidade do dogma - A eternidade do sentimento".

200286: As farpas $V$, pág. 304, continuação da carta anterior.

230386: As farpas XI, pág. 269, com o título de "Aspectos de verão - A feira das Amoreiras - O jardim zoológico", datada de maio,1885.

270386: As farpas l, pág. 261, com um cabeçalho de assunto principiado por "Figueira da Foz".

180586: As farpas III, pág. 139, com o título de "Ernesto Chardron", datada de Agosto, 1886.

190586: As farpas V, pág. 283, com o título de "Do 'Padre Eterno' e da sua velhice". Os começos não coincidem.

210586: As farpas $V$, pág. 289,continuação da carta anterior.

300786: As farpas III, pág. 129, com o título de "Anselmo Braamcamp", datada de Dezembro,1885. No livro foram suprimidos os dois primeiros parágrafos.

020886: As farpas III, pág. 146, com o título de "O rei D. Fernando", datada de Dezembro, 1886.

040886: As farpas III, pág.150, continuação.

150886: As farpas VI, pág. 39, Com o título de "A mania das grandezas e a melomania, doenças hereditárias na sociedade portuguesa", datada de maio, 1886.

220886: As farpas III, pág. 153, continuação da carta de 2 de agosto de 1886.

230886: As farpas III, pág. 160, continuação da mesma carta.

250886: As farpas VI, pág. 53, continuação da carta de 15 de agosto de 1886.

290886: As farpas VI, pág. 59, continuação da mesma carta.

300886: Idem, pág. 70, continuação.

310886: Idem, pág. 271, com o título de "Entre o Tejo e o Douro", datado de Caldas da Rainha - agosto, 1886.

020986: Idem, pág. 177, seqüência da carta anterior.

080986: Idem, pág. 185, datado de Óbidos, 1886.

130986: Idem, pág. 195, datado de Alcobaça, 1886. 
290986: Idem, pág. 203, seqüência da carta anterior.

201086: Idem, pág. 211, seqüência da carta anterior.

130387: As farpas III, pág. 167, com o título de "Fontes Pereira de Melo" e datado de janeiro, 1887.

200387: Idem, pág. 175.

220387: Idem, pág. 183.

210487: As farpas II, pág. 187. Texto endereçado ao Diário Ilustrado, com data de outubro, 1874. Foi suprimido o primeiro parágrafo na publicação da Gazeta de Notícias.

220487: Idem, pág. 205.

080288: Pela terra alheia II, pág. 7. Data no corpo do texto: 6 de novembro de 1887.

041188: As farpas VI, pág. 287, com o título de "O Grand Prix, vilegiatura de Sintra e de Cascaes, perfis de senhoras", datada de Outubro, 1888.

121188: As farpas VI, pág. 293, continuação da carta anterior.

251188: Idem, pág. 293, seqüência da carta anterior.

301288: As farpas VI, pág. 255, com o título de "A noção do amor", datada de Setembro, 1879.

010189: As farpas VI, pág. 264, continuação da carta anterior.

160189: Idem pág. 271, continuação

301189: As farpas XI, pág. 291, com o título de "O defunto rei D. Luís", datado de dezembro, 1889.

261289: Idem, pág. 297.

231190: John Bull, pág. 291, com o mesmo título da Gazeta de Notícias, datado de Lisboa, outubro, 1890 e informação dos editores ter sido publicado no jornal na seção "Cartas portuguesas".

241190: Idem, pág. 303.

251190: Idem, pág. 315.

050191: Figuras e questões literárias I, pág. 231, com um pequeno sumário e informação dos editores ter-se constituído a matéria em "prefácio da edição monumental do Amor de Perdição", publicada em 1889.

110191: Idem, pág. 240.

120191: Idem, pág. 251.

130192: Idem, pág. 260. 
180191: Idem, pág. 271.

290691: Folhas soltas, pág. 197, com o mesmo título da Gazeta de Notícias e informação ter sido publicado no jornal em 29 de junho, 1 e 3 de julho de 1891.

010791: Idem, pág. 207.

030791: Idem, pág. 217.

240891: John Bull, pág. 277, com o título de "O processo Gordon Cumming" e a informação dos editores ter sido publicado na Gazeta de Notícias, na seção "Jornal de um lisboeta".

290891: John Bull, pág. 286, continuação da carta anterior.

110991: Arte portuguesa I, pág. 271, com o título de "A fábrica das Caldas da Rainha" e datado de Caldas da Rainha, julho 16.

130991: Idem, pág. 279.

160991: Idem, pág. 288.

280892: Pela terra alheia I, pág. 123, datado de Madrid, 6 de junho de 1892.

290892: Idem, pág. 139, datado de Madrid, 7 de junho.

300892: Idem, pág. 155, datado de Madrid, 9 de junho.

180992: Idem, pág. 169, datado de Madrid, 10 de junho.

200992: Idem, pág. 178. No livro a data: Madrid, 12 de junho está na pág. 173, que não daria a medida usual de uma carta, por isto, talvez, o corte diferente no jornal, para a carta não ficar muito curta. Pode ser também que o texto do livro tenha se baseado no manuscrito.

270992: Idem, pág. 187, conclusão das cartas anteriores.

160195: Contos e páginas dispersas, pág. 279, com o título de "Verão de S. Martinho" e a informação de ter sido publicado na Gazeta de Notícias em 16 de janeiro de 1895.

170195: Figuras e questões literárias II, pág. 50. Seria desejável a confrontação dos textos para a dissipação das dúvidas sobre seqüências, datas de publicação, etc.. O início da carta da Gazeta de Notícias foi publicado em Contos e páginas dispersas, pág. 279.

180195: Idem, pág. 60, seqüência da carta anterior.

260395: Arte portuguesa II, pág. 211, com o título de "Silva Porto" e a informação de ter sido publicado na Arte Portuguesa, ano I, no 2, fevereiro de 1895. 
250695: Figuras e questões literárias II, pág. 141, com o título de "Menos um". Os editores informam que foi publicado no Suplemento do Correio da Manhã, de maio de 1895, consagrado à memória de Manuel Pinheiro Chagas. Houve alterações no texto da Gazeta de Notícias.

210895: Arte portuguesa I, pág. 9, com algumas alterações.

280895: Idem, pág. 25, seqüência da carta anterior.

030995: Idem, pág. 58, seqüência da carta anterior.

261095: Idem, pág. 66, seqüência da carta anterior.

281095: Idem, pág. 134, seqüência da carta anterior. Há grandes saltos de páginas que seriam desejável confrontar.

130208: Costumes e perfis, pág.291, com informação dos editores ter sido publicado em Perfis Contemporâneos, 1895.

110308: Últimas farpas, pág. 223, com o mesmo título do jornal. Há uma epígrafe de Paul Verlaine e um resumo encabeçando o texto que não consta da Gazeta de Notícias.

271208: Contos e páginas dispersas, pág. 33. No livro, o texto ocupa 59 páginas. Deve ter sido publicado apenas o primeiro capítulo.

050209: Folhas soltas, pág.321, com o título de "A tarde de 1 de fevereiro de 1908 " e a informação dos editores de ter sido publicado no jornal $O$ Portugal, de Lisboa, de 1 de fevereiro de 1909.

100209: Pela terra alheia II, pág. 167, com subtítulo de "Impressões de arte". Há informação dos editores ter sido a matéria publicada na Ilustração Portuguesa, de 1 e 8 de fevereiro e 1 de março de 1909. Ao que tudo indica a última parte não foi publicada pela Gazeta de Notícias.

170209: Pela terra alheia II, pág. 178: seqüência da carta anterior.

070211: Últimas farpas, pág. 7, com título de "A revolução de outubro".

140311: Últimas farpas, pág. 39, com o título de "O sebastianismo nacional".

110511: Últimas farpas: pág. 51, com o mesmo título do jornal.

130711: Últimas farpas: pág. 63, com o mesmo título do jornal.

040911: Últimas farpas, pág. 75, com o mesmo título do jornal.

150212: Últimas farpas, pág. 89, com o mesmo título do jornal.

040312: Últimas farpas, pág. 99, com o mesmo título do jornal.

180312: Últimas farpas, pág. 109, com o mesmo título do jornal.

010712: Últimas farpas, pág. 131, com o mesmo título do jornal. 
020712: Últimas farpas, pág.138: seqüência da carta anterior.

200712: Últimas farpas, pág.179, com o mesmo título do jornal.Na Gazeta de Notícias há uma continuação da carta publicada no dia 210712 que não foi recolhida em volume.

291212: Últimas farpas, pág. 165, com o mesmo título do jornal.

010113: Últimas farpas, pág. 172: seqüência da carta anterior.

130113: Últimas farpas, pág. 121, com o mesmo título do jornal.

070213: Últimas farpas, pág. 201, com o mesmo título do jornal e informação dos editores ter sido publicado em fevereiro de 1913, no semanário portuense $O$ Correio.

200213: Últimas farpas, pág. 145, com o mesmo título do jornal.

040613: Últimas farpas, pág. 157, com o mesmo título do jornal.

270813: Últimas farpas, pág. 187, com o mesmo título do jornal.

Observações:

a) Não foram registradas colaborações nos anos de 1893, 1896, 1897, 1898, 1899, 1900, 1902, 1903, 1906, 1907, 1910, 1914. 
4 - Quadro comparativo do número total de colaborações

publicadas anualmente com o número de colaborações não encontradas em livros do autor.

\begin{tabular}{|c|c|c|}
\hline Ano & $\begin{array}{l}\text { Número total de } \\
\text { colaborações }\end{array}$ & $\begin{array}{l}\text { Colaborações não } \\
\text { encontradas }\end{array}$ \\
\hline 1877 & 11 & 11 \\
\hline 1878 & 40 & 18 \\
\hline 1879 & 39 & 23 \\
\hline 1880 & 24 & 20 \\
\hline 1881 & 31 & 13 \\
\hline 1882 & 41 & 22 \\
\hline 1883 & 44 & 15 \\
\hline 1884 & 48 & 4 \\
\hline 1885 & 57 & 27 \\
\hline 1886 & 52 & 26 \\
\hline 1887 & 13 & 8 \\
\hline 1888 & 11 & 6 \\
\hline 1889 & 12 & 8 \\
\hline 1890 & 7 & 4 \\
\hline 1891 & 29 & 16 \\
\hline 1892 & 6 & - \\
\hline 1894 & 3 & 3 \\
\hline 1895 & 16 & 6 \\
\hline 1901 & 5 & 5 \\
\hline 1904 & 1 & 1 \\
\hline 1908 & 3 & - \\
\hline 1909 & 4 & 1 \\
\hline 1911 & 5 & - \\
\hline 1912 & 8 & 1 \\
\hline 1913 & 6 & - \\
\hline 1915 & 1 & - \\
\hline TOTAL & 517 & 236 \\
\hline
\end{tabular}




\title{
5 - Pequena amostragem de colaborações inéditas em livros do autor
}

\author{
5.1 - Domingo, 21 de setembro de 1879
}

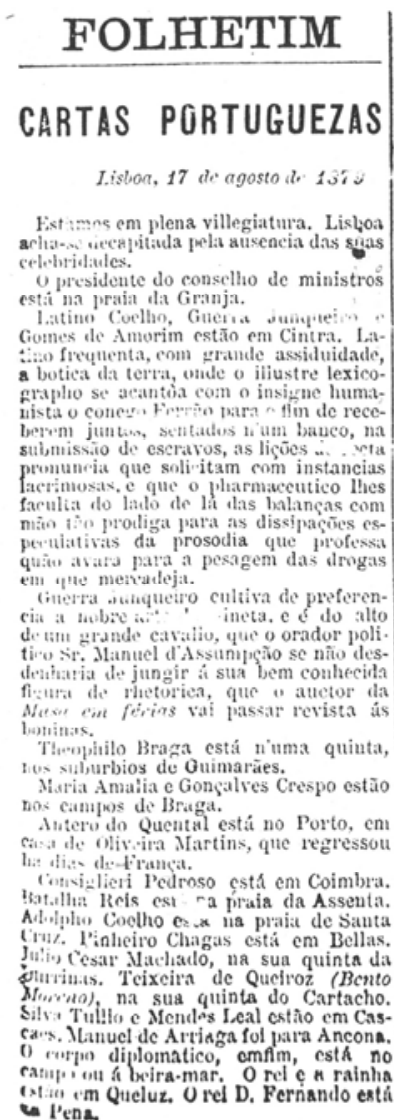

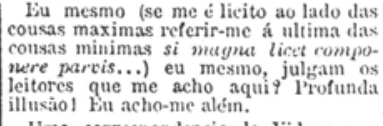
IIlusiol corrospondencia do Yilago, pu-
Ulicala hoje no Diario de Noticias, antá, eme Vidago. O articulista vilt-me no cortejo que veiu esperar um conselleciro
que ia de Lisboa. As demais perso:at que ia de lisboa. As demais pessoas
encorporalas no prestito do conselheiro encorporalas no prestito do conselherir
tambem mo viram. Parece que neste mo-

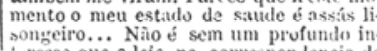
Leresse que o leio na correspondencia de
Vidago. Praza a Deuls que en contimue a dar-me bem n'aquella afrazivel ryitio
que as azuas alcalinas, de que lit extou usando. me beneflicem tanto o figato como outtra qualquer viscera de que

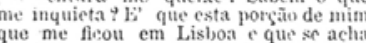

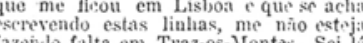
azeido filta en Traz-os--ytontes. Sei 1 cparado deste bocato que para aquit

Ai de nim! como terei eu procedido
nat sociedade transmontana? 8 facto do

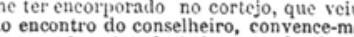

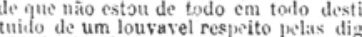
ividades legalmente constituidas. Possa continuar a manter-me n'esses sãos print
cipios por meio dos scus consel os. Re commendo-me com empenho ao solredito
corresirondente para que, continuando a corresipondente para que, continuando a
ver-me e a interessar-se por mim, elle me proteja contra as más companhias e con rigorosas providencias para que me nà
faltem em Vidago, emquanto eu lá est ver, roupas lurancas.

Bon souper, bon gite et le reste. -

Alem dos grac partiram de Lisboa para migressar no prinnciplo do inverno jus. com a abertura da opera, para voltai itan em Queluz. O Ored D. Fernando est com ns poras arias e com as novas

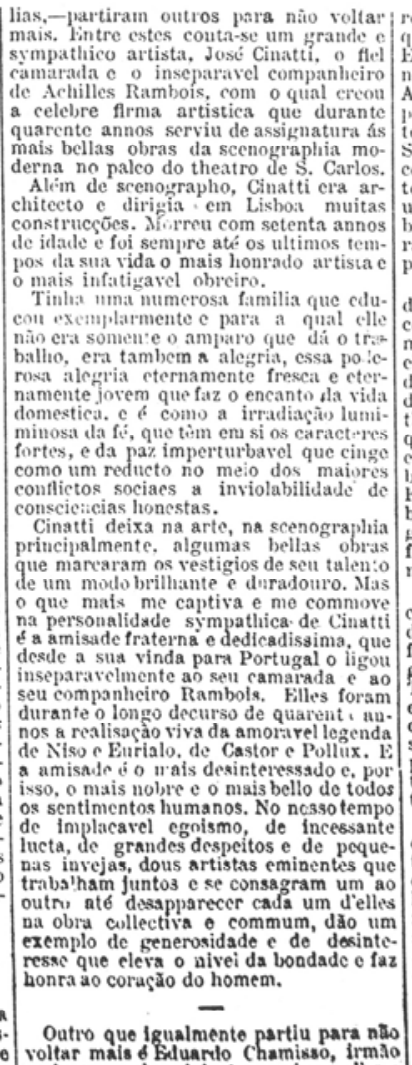

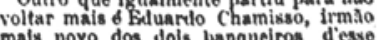

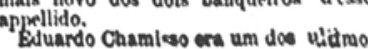

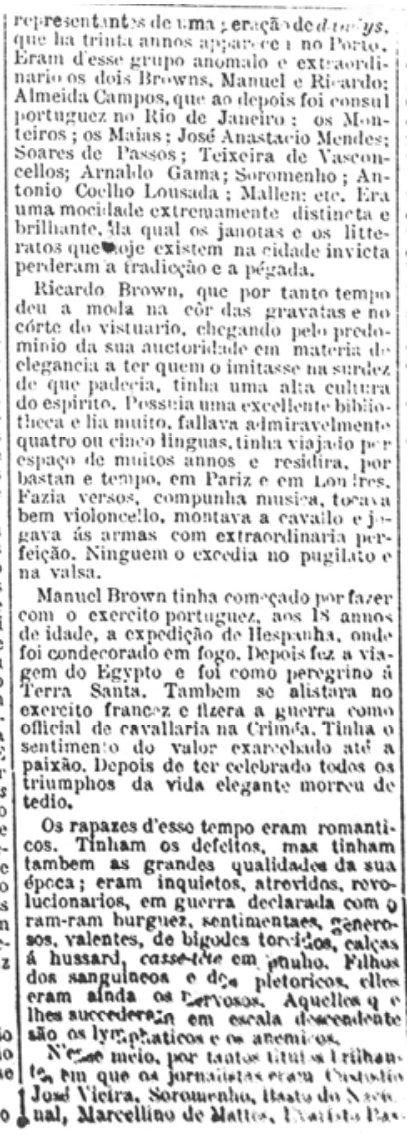

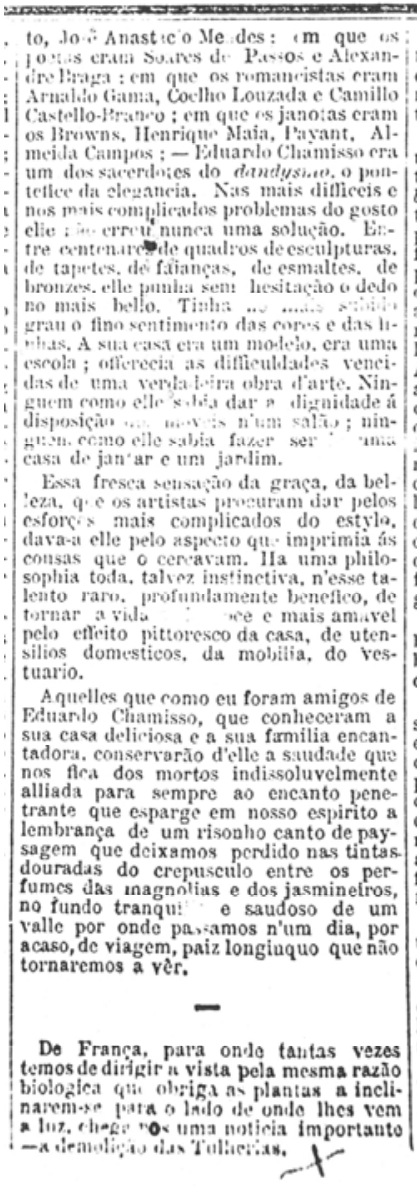

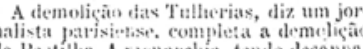

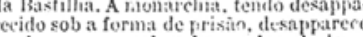
A be agora sob a forma de palicio. cndas attrocidaules commettidtas em $\mathrm{sa}$ In plaisio dos reis de França. Na Pas illa esteve por muitas veres emparcdado, relo crime de ser um expirito, o espirit:
rancez representado por" Voltaire. Ness

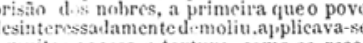
a muitus presos a tortura, como oe reco Mros encontralos nas ruinas dos carceres.
Alii estiveram presos velloos de oitenta annos e crianças de sete, entre muros do
doze pés de espessurn, em traiolas de ferro. ande desature rebiam a luz dos

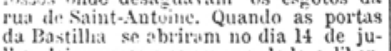
lino dois presos a quen era dala a liber-
daile tinham enlouquecido. Um outro onton que, havendo dete:-minado morr forca os alimentoo, metendo-lhe uma
grosa cliave entre os dentes. Para merecer estes supplicios ten brosos não havia condenumação dos tri-
bunaes, bastava a léttre de cachet, a real den

Era preso na Bastillha todo aquelle que

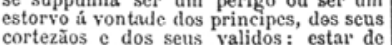
cortezz̃os e dos seus validos: estar d
posse de um segredo de Estado ou de al. cova, ter feito um opigramma a alguma
das amantes do rei, ser o marido de um mulher desejada. ou ter desembainhado a espada a um recanto de jardim em defeza da honra doca
ẵo mascarado.

A q̧údada da Bastilha foi, portanto,um dos masores triumphos da justiça e da digni0 palacio das Tulherias era o cerebro do que a Bastilha era o braco. Nas Tu-
lheras havitava a idéa ; na Bastilha rosidia o facto.

Carlyle descreve o aspecto d'ouse pa a Revoluçato, segundo Arthur Young. sua magostado parsear

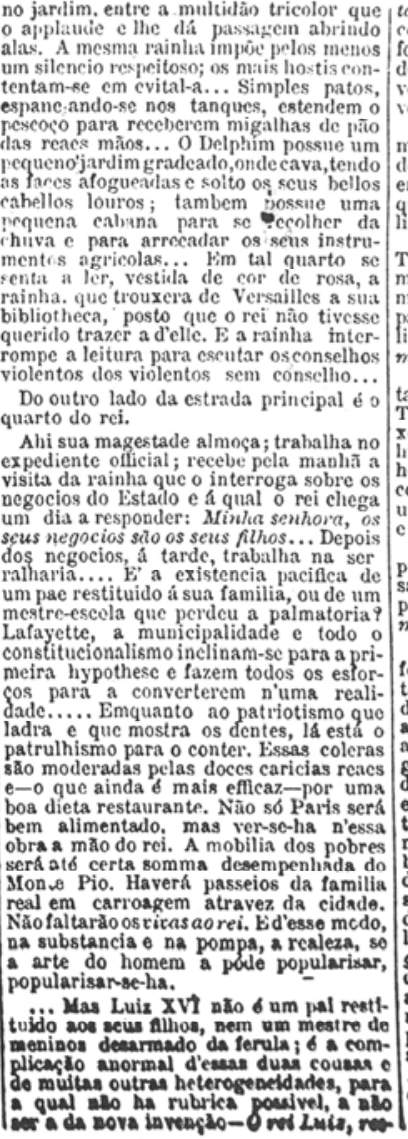

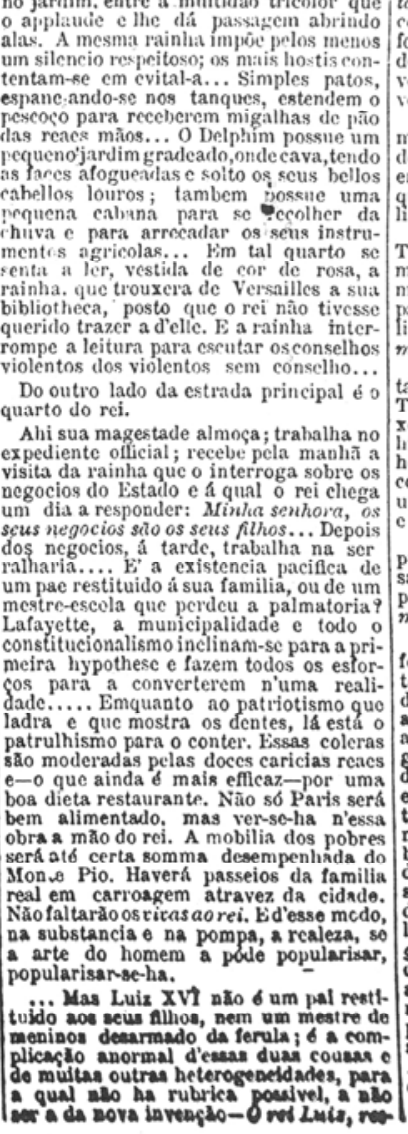

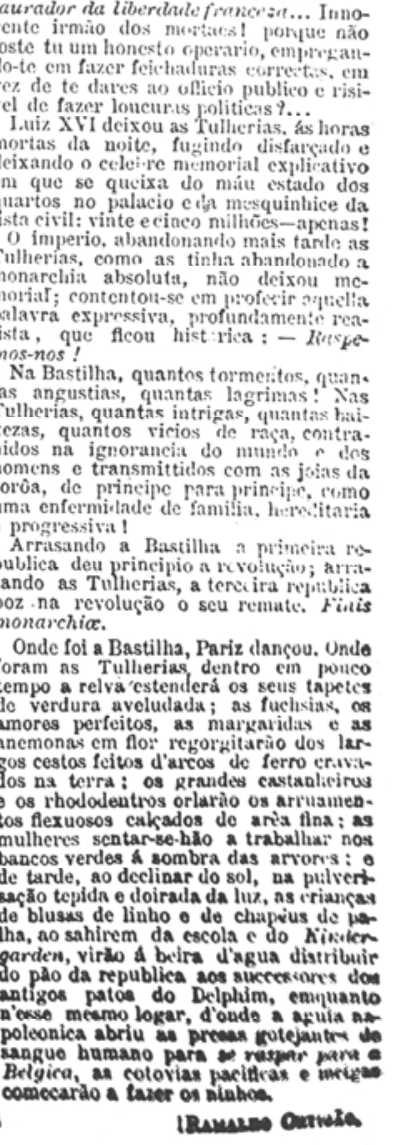




\section{FOLHETIM}

\section{CARTAS PORTUGUEZAS}

Trarana, 2 oe setesuro.

\begin{abstract}
A Ruposeira é uma collina quo abriga - Trafaria pelo lado do sul o fórma a con. tinuaça o a parte da mont unlia que so prolonga desde Cacilhas at $\mathbf{a}$ costa pela niargem ciquerd I do Tejo.

l)a extremilade diesta collina, a ocstc a vista of sorprendento o magnilica. $A$ linha do littoral arqueia-so cntre os dols cabos de Evpichel e da lioea sobre o lar. fo occano azul, que as cinbatcaçies de recea com as sus velas litinas sulpican de pontos brancos, e esguias como azzs de cisne, scintillando ao sol. Ao norte a serra de Cintri recorta no céu as suse corvoras graniticas, de um tom riolaceo. Cascacs com a sua antiga fortaleza den. tala e inoftensira, o castello de $S$. Jutiào da barra, Camavellos, Odrae, Paģo di.Ircos, a Boavis gem, S. Josid de Ribamar, - D.i-funto, Pedrougee, alezram con os n hexos lomros das aldeias bitldas do sol a vegetaşio cecura c pobre da bacia 's $T$. jo. $A$ architectura rectiliuea do priacio da duda pó nas abas da serr. a de Monennto, tocla picada do molcinos, a grando Sorma qualrada e bra seca da mansio real. 0 mosteiro dos 'seronymos o a Turro do B.jom parer en o fragmento precioso de apa rer, sa de marmore cahida da follotte am astro a beira d'agia. Um pouco

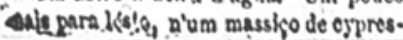
xtensa uma grando nodoa cryerilinhada, evios contornos se tiluem na cjo da aria para o lado do mar, franjado do expuma a toda a extonsto da costa n'uma longa Ata branca.

Do alto da grando eminencla in ltapo. cem, talliada a plque sobro esca pla icic, vicm-so $\mathrm{em}$ baixo as, farcadas recortsulas no juncal como remethos quadralos pospontados do figueiras; ao ado de cancellas pintadas do verinelho alvej am os muros dos casues; nas ciras redont is reluzem, como montes d'ouro, as ecplyas de millio, ou trolam on eirculo sobro a pallıa, na debullia do trigo, cguas velhas, descadelradas o lanzodas as codoraizes, desper!adas pela passagem de un burro selfitario o pensatilion un pelo mugi.'u de uma vacea pastandocom sua cria as lado, passan cm revosdas cobre as viahas: o no silenclo da rasta paicagon tranquilita oure-se $n$ atts tssobiala pio pastor que seguo ao losac, t'um a ficira microscopica, o rebatho do cabras.

Na pldels da cosia, as cabanas cobertis do culmo denegrido, agrujadas en torno do campanarlo da igreja, lembram as cubatas do uma populacto africana civilisada a missas o a surras por una missão de jesuitase.
\end{abstract}

tes, o cemiterio dos Prazeres; o ao fundo. n'um enorme amphitheatro, a casaria de t.ikboa, do que mobresahem ns cliaminés cncarnadas das fabricas, manchando a limpidaz in rio com a sompera movellis

cinzenta de oigam dennachos de fuiuv.
Na raiz do monte da Ranoseira cstendem-so 0 juncal c a porousto maritima da costa do Caparica.

0 juncal alastra na planlelo cliata $\mathrm{e}$
Do alto da Raposcira vè-sc bem com lerantando-se inesperadamente mitou no mocto o trabatho da pesca. 0s bareos fittorat portuguez ejuinheatos homens. savelros, pintaidos de negro,da fórma de 0 inverno é a fome para os pescadore 3 mcias luas, descmbarcam a pescaria tra- da costa. Os mestrés das campanhas, zilta do alto. Ilomens $\mathrm{e}$ mulheres, metti. scnhores dos bareos e dis veles, dus ta agua até o busto, arrastam na tam então ans homci.jua malta os aliprais as longas redes da sardinha, cscamada pela friçào da arèa. Aperias coIhida, a surdihhs of immodiatamente carregada cm canastras e ao longo da praia. Fela linha da mari, os cavallos ajoujados, conduzidos a arreata por pequenos de dez annos, galopeam para a Trafaria, azendo tilintar alegremente as campaihans pendentes das cabeçadas. E' $\mathrm{ra}$ Tra faria que a sardinha da costa embarca pira o mercalo de L'sboa, d'oude se cspalla depois nclo paiz inteiro $\mathrm{c}$ por uns parte da licspanlia. Durante o bom temro de verio, entre a Tr.ifaria e a cost i 10 carallos galopam constantemeate pels beira do mar; $e$ os pequenos, a pé 0 lado dos animacs ou un pouco atra d'elles, seguros aos cabrestos, accimpaalıam-0s sempre corrento. airez. crdos até 0 alto da perna- iazendo chapinhar a agua dèvaixo dos pís nus. E' n'esta itnunastica que so fazem os primciros audarithos do mundo,-os ca'sacivos ila costa.

No inverno, cmequanto sopra o terrire? reato do syeste essa o trafero.

Como dizem os pezcadores, o suestc ef - vento que mais almas tem engolido. E; o vento da molonha ressaca que lera c nio traz. Empolado pelo sueste, o mar em allas ondas, que quebram de repente bate na costa de cima para baixo como um pilio gue descose, descesnjunta, desfas lim bario dentre de um minuto. De. uma rez, exa un so dia, o sucste mentos que elles lhes pagam com o profucto do seu trabalho no verĩo. Um arerno basta para empenhina um perceador para toda a vida. No contrato de locação de serrísos entre o:pescador c o mestre, cada pesea deluz-se cm princiro logar a a igreja, depois o quinhro do mestre pela rele, o quinhaso do mestre pelo barco, o quinhão do niestro pela barraca em qué dorme cm terra a campanha. 0 que sobra o o quinhăa do3 pescadores; que cllco cmpregitis em amortisar a dirida e cm compr.ur pio e vinho. 0 pio e o virho é ainds o mestre quem os vende por um preso muito superior ao custo. De modo que, exceptnando o que recebe a igreja c 0 que recebe o flsco, é o mostre da pescaria quem no fim de contaz, directa on indirectamente, reccbe tudo o que produz a pesca.

Os cabazciros. de que acima fallei, sũo os homens valoro30s emancipados d'ess expoliazĩo infame.

0 cabazeiro năo cmbarca; compra o peixe $\mathrm{cm}$ arrematazão na praia, carrega-o em dois cabazes scruros nas catrenidudes do um pau. São mil ou mil e quizinentas sardinhas, um peso de cinco arrobas, que elle pǘc ao hombro e vae render pclas casas, de terrá em terra, num circulo de dez ou quinze leguas. Vestidos apenas com um largio calsão de inho, a camisa, a cinta 00 barrete de - pescador é um cscravo. Do producto de pesada contribuição para o fisco e para lai, os cabazciros ponenrem o areial trotandn... motemhis, enterrando os fr's na areda, c.... wa sa velocidade que nerlịum cavallo aguent, suando $\mathrm{cm}$ bica molliados como as sahir do um banho correndo seripro debaixo do sol a pino, bebendo o espago com o ollar fxoc cs. tupido, o largo peits arquejante e os beisos chcios do cspums; quo cnxi:gam ao birrete ou thes cai cm baba dos cantos
da buea quando fallum. Ao regressarem com os cabazes raslog, cintregam a muliner ou a fillas o producto da renda conien com una voracidads bestial, estiram-so 110 chão, dormen cinco ou scis horas n'um sonno to chumbo, e crguemse para correr a praia, cartegar da noro c tornar a partir.

la fui houten pela :uahi almogar Raposeira - un grande caixo d'uvas moscatel c uma codea te paio de milho fresco c dourado, qua levei de casa n'uma algibeira.

Nouta algibcira levara 0 ; Soneros e Rimes de Juin Guimarics, e fol no antigo forte derrocalo que corea a montanha, csten lislo no sol como uma sardonisca, que en li crte delicado tirro.

Que contraste entre a natureza que me rolcuva, c a leitura interposta n esse csrectuculo!

linguanto $1 \mathrm{~cm}$ buixo as mulheres. d: formas grouss e robustas, ajudavan os homeis a puxar a redo com uma cantilenaseiragem, o lirro dizia:

- Corro dots cystics que se rão crrantes, D'tun quicto ligo a vaga laz turrando, As nocess almas junjas deslisando, A za com azi, rosm expeliuntces Como dois cjancs one sc rĩo cramtes.
Em ums-das ciras onde we-debulhava aspera do um moso bradando: $E /$ t musa l... Eh ! ruça l... O rebanho, que passara no juucal, tinha trepado ao monte, c, ao $80 \mathrm{~m}$ do chocalho, atravessava as ruinas do forte, vagarosamente, deixando no ar, com um chiciro picante de suor, a exhalação quente do pello dos chibos. A pagina cantara:

$\Lambda$ fria lua sobre nós pairava:

Rescendendo a baunilha, suspirara

$\Lambda$ aragem, quente ainda do mormaso.

E ella pousou o alabastrino braço Nu sobre o marmor. Scu olhar brill Os mudos olhós meus de espaso a espaso.

Luiz Guimarães tem a indole suare e meisa dos parnasianos. E' nm artista de mào fna, lere, senhoril. A vida captiva-o relos scus aspectos tnais delicados c mais linta predilects, elle tem a paixĩo do azul. Os seus versos assim como a sua rosa viem a transparencia luminosa do céu nos golfos do mediterranto. 0 sen talcnto ten uma susceptibllidade d'armb nho. Cs contactos da rude natureza escabrosa ou da grande multidio grosseira elle é um primeiro aldido â legacăo da elegancla. Viajs no paiz da arte em coupesalso, res guarílado do frio n'um pellica de rapoza aml e seguido de dois criados. 0 sen estrlotem um laror de renda, uma suavidade do velludo e nn
Reunimo-nos todos no terraco: puros. Como os rintcres, que tìm uma oura, de cintura fna, ama ne rocanto confortareis, ao pe in :ume, abrigada undo de uma carractim preto, ou if molas sobre as ruas serpenteantes clisas de un parque; 0 o sentimento da nátureza penctra-a mais pelas - paisagens - de Corot c do Millet, pclas symphonias de Bach e de Beethoven, do quo pelo aspecto 1 mmediato das forestas o dos mares. $\mathrm{Na}$ colleç̧̃̃o, tão sympatlica, que cu acabo de lèr, ha pequenas obras primas cinzeladas com um esmero inexcedircl. - Danubio Azut, a Venus de Milo, a Moite da aguia, Amar eser amuto a Noitc da aguia, Amar e ser anutio, - Filho, a Arte poetica, Miss Pcrfection $\mathrm{em}$ perféciono com as mals tellas obras da escola dos parnasianos francezes, o3 mais correstos artiaces da litteraturamoderna. A csses merecimenlos Luiz Guimarães reune o de so ter cunscrvado brazileiro atrarez de todas as influencias com que arte curopéa actuou na formação do seu espirito. Ser da sua terra 6 a primeira obrigąũo de nm artista. Courbet nunica fez paysagem fóra do scu departamento. Os puizes estrangeiros visitam-sc, estadam-se, examinam-se; mas entre elles o a nossa alma ha sempre uma ligeira nevo que distancila 25 cotrsas o pertirba-an suas justas e exactas proporsũes. Fóra da patria a riszo estreita-se e a lucidez diminue. Poryue para um artista nã basta presenciar um espectaculo para reproduzir a sensagão que elle inspirà sreciso, alén de o presenciar, sontil-o. Por isso nada mais penetrante em todo livio de Luiz Guimarães do que os versos que tèm por objecto assumptos brazileiros. Na zoesin Nhatha o sentipgento Emquanto affuclla bocca fulgurante, Mais pur.a que os cristacs, Repentia-mo a chronica elegante Dos ultimos jornaes

A roz da escrava,-trẹmula, quelsosa, Expirou na amplidão, Longa como uma nenia dolorosa, Triste como a paixũo.

São igualmente bẹllas as poesias que si intitulam: $A$ noite de S. Joao, A madrita 


\section{CARTAS PORTUEUEZAS}

Lisuox, io de feveroiro de 1933.

Dois portuguezes distinctos, cada um no seu genero.- - um urtista o um sportmnn-acabam de tornar os seus nomes celeores em Franja : um d'elles como autor de uma opera applaudida, o outro coto rén da um proce so de sensação.

O artista d Augusto Machado, mais geralmente comhecilo en Lisboa pelo nome de Mrehrdinho Mrsico.

De uma fan: lia do abastidos burguezes, liericiro de uma fortuna que the garantivia $a$ indonm toncia do ocio, tĩo inveg da peia nocidate portuguez, cite bom rajaz parecia uatur.u!ments destinalo i carreira te jannto. E' essa a posi, to secial preterisla por toto o inacobo de liom porte, sullicientenente rico para realisar na torra a missĩo do a:lorva! um: hombreira de porta no Ciniado, dimate o dia a de occuiar uma cadeira do S. Curios duranto uma parte da noite, scndo, nlem d'i-so, par de Lunceiros nos saraus do inverno, banihisti $\mathrm{cm}$ Cuscaes no vario, noivo em projceto pari spris namoros de sociedule, commendator de Carios ItI. freguez do alfainte Feil e membro da Sociedude de Geographia.

En vez de tão risonlio e triumphante existencia. Augusto Machado preferiu ter a sorte inquieta d'aqueiles que se renciem o tormento de um ideal, e, depois de haver seguilo todo o curso do conservatorio em Lishoa e ter estudado harmonia e contraponto cm Pariz, amarrou-so a $u$ m piann, e passou toda a súa mocidale a tribalinar.
Fez representav durante os ultimo: annos nigumas ligeiras operctas accom. modadas aos recusos technicos da com panhi i dia Trindade, e compoz expressa. monte pariz nas festns do centenario di Canues uma trande ode symphonics in. titulada Camö́s e os Izusirdas, da qua uponas se chegon a cantar em Lisboa c soneto Alma mista gentil que to par. tiste, romanza par, tenor. Para se te? polido desempenhar na integra essa v'sta composiço, haveria silo precisc qua o roverno, que subsilia com quarenta conios de réis as companhias estrangeiras do S. Carlos, abonacse algumas libras em favor d'esta obía nacioval; e o govérno entenden com subtil parcimonia, que os grantes factos da historia patria se ach tvam sufticientemente celcbralos en musica, desfo que tinhamos $j: i$ a polka sentimental offerecida de graça a sua magestale a rainhá o intitulada O anjo dre ceridude, o galopa das Culitrdas do Passcio Publico, - Ilymanar dos Casadinhos sobre un matiro brazileiro do Quisomua. o facto io marquez de Fomual, o dos nowos imposios, e outros.

Foi nreciso que na segumda cidade de Fr mega o theatro lywico de Marselha sc ab lançasse a por em seetia uma opera Io mala ventura'o eompositor portuguez. para que finalmente se soubesse que o Heachainhto Musico of am maestro que a propria critica franceza pöe na plana Hos Mrsanets, dos Delibes o dos Anbroise Thomas.

$A$ opera do nosso compatriota intitul-so Lamiene, e esceipta solue um lineto extrinido pelo Sr. Cuion, do bello drama feito por Paul Maurico somen romance do George Sand Les beaus Messicury the Loir-Dori. 
U!n jornalista francez. resumindo em poucas palurras a opiniäo geral da imprensa marsclhezn. acerca d'esta opera, diz o segrinte : “ $\mathrm{A}$ musica do $\mathrm{Sr}$. $\mathrm{Mra}$ chado da o tertemunho do uma solirh instruçion musical, de uma invençito limitad, mas distincti, de un estylo que participa an mesmo tempo da graça ita. lima c da factura carinhosa do $\mathrm{m}$ is moderno tios mestras, Charies Goumo!. G'jublics, pein su: patto, corrobotut esta sentença com os sens applausos, consagrando deflnitivamente a reputaç̃o

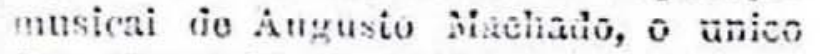
dos compositores portuguezes que nos nltimos cinenenta annos se tem foito julgar n'um the itro estrangeiro.

Osyoriman de que se trata, é Jeronymo Collnẹo de Jaguhines, fliho do fallecido conde de Condeixa, o qual habitou alfrum tempo o Rio de Janciro e se casou ahi com umit senhora brazileira, hoje enmiessa de Condeixa viuva, resilente em Liebor.

Iepois de ter percorrito qunsi toulas as côrtes da Europa como aldido de iesaçĩo. Jeronymo de Magalhäes passon a dispanibilidace na carmira diplomatica $c$ fixon-se cm Pariz, onde es conheciho sen catresot, mobiifulo con graudo primor artisticn, na avenifla dos Campos Blysios.

As stass atturges o os scus cavallos ic solls, as suas c.rroriens, os scus wathere, as sens groomis, os tens zisfons e ai sulus pelliças, suio citalus no Dois de Boulogne como motlelos to gene:o, e nao ha pariziense verdateiro teste Longchamps, atravez do bairo da Magdalenn e da linha do boulevard, ate Shotel Drount, queltie näo saba o aome, thasaificato entre o dos orimeiros horsenen to sport trancez. is com efreito un cayaliéró notavel é um recheiro de mineira ortem.

Comprancio de nma vez no Rilnatejo icla m lien quantin de 39 linus uma lindisima emtat thita cono ingovernavel

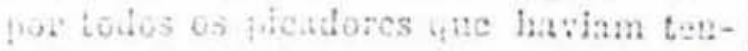
twh submet bita ao freio. Jesonymo ntreton-1 a um tilbury o forernos as

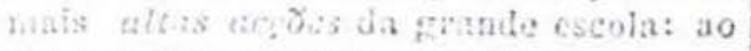
cubmar tama esquina, cmphitave-se nos verase do raporeso veniouio, rutiven pata a direlta ou para a esquerila soirc us potas tr anims; e, n'uma ondulaçāo tho ciegute como prectisi, dava a rolt : hos pus e trosoguia stepardo ao troto

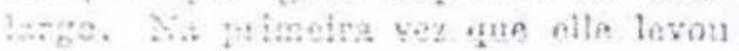
wo trois case erbelto atimal, comprou-th'o for 5.000 fraue s um nogociante de cavalies dos Carapos Eijsios. A Thrü, apolavrada a descer do Eois, erreztuou

se no dia seguinte sa quatro boras di tarde. O compridor atrelou em seguida, subitu s almofarla a tomou ag gnias. $A$ 's cinco horas da tarde, a carruagern em que so flzera csta experiencig, estiva n'um molho, com os tirantes partilos sobre o caminho de Saint-Cloud, a egua tinha desnpparecito, o o seu novo dono ia em maca p.ra uma casa de earde qunsi ne mesmo est.de em que delxara o carro abandonado no macadam.

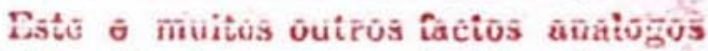
tinham-lho feito $\mathrm{nma}$ verdadeira legenda te superioridade no sport hippico.

Uhimamente havia emprehendido corr o juven duque de Morny a ompreza io uma mala-posta quotidiana entre Nice e Aconte Carlo, durante-n sensort. A rnv-

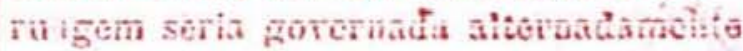
pelo duque de Morny e por el!e. O bookmaster, servinio de conduetor, sra $\mathrm{nm}$ antigo cupitão dos horsc-guards. Calla logar na berlinda custaria cinco luizes, e min logkr do howis na almofada sorik reservado frara a possoa convidada poio cocheiro. O Joctscy-Czub de Nico tinla cedilo para este ser iço do alto luxo uma parte das suas cavallariças, o hivia jit passageiros inscriptos para muitas viagens. 
E' n'este comenos que, em quanto 0 rasscio das inijlezes espera cm Niee o projectado mail-coach, o nosso compattrinta nos ry parece inesparad umenta wax tribunacs francézes perante a on wieme charabre correctionelte, accusido do ctime de adultirio juntamento $\mathrm{com}^{\mathrm{i}} \boldsymbol{\mathrm { r }}$ sua cumplice Mistress Hart, a qual tenta logar com elle no batro dos réas.

Mistress Hart. Estella Ketty Kardwig natural do Cincinnatti, com vinto o oito

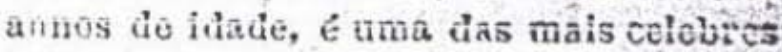
bellezas da-coloni : nmericana em Pariz. $\mathrm{O}_{3}$ suus encantos physicos, o seu rsarbo. a sua admiravel toilette coinmovem do "dmiração o tribuual, e um murmurio sympathico de respeito osthotico esvoaç como um perfume pectico pelas pregas das togas e pelas folhas dos autos, na templo da justiça.

A mimosa e deslumbrante oreatura olha com espanto soberano para o juiz caturra, que se nũo apressa a descer do cstrado e a cahir de joelhos enrólnuto na heca aos seus divinos pés. $A$ sua voz de contralto, doce, ondulante o victoriosa. como se cant issa uma barcarola, responde as perguntas do magistrado como o canto de uma cotovia pode responder uos gemidos de um vitello.

A pobresinha, em sua indiferenga augelical pelas grosseiras formuias das. justiças terrenas, ném mesnio sabe ao certo se é casada ou nãol Miss qucr-tho parecer que não. is corlot quo clla viveit churante oito annos cem o-Sr. Hiart. parte queirosa, mas nunca durante cssa vila en commum se fallou entro elles em casamento, \& nйo ser, passageiramente, um dii em Londres, om quic \& Sr. Hart foi com clla de visita á casa de um clergyman, o qual, depois do alguns minutos de conferencia, thes passot uma certidĩo do m'trimonio. Mais târde, em Pariz, o odioso Sr. Hart abandonou-a nas palhas humidas do um palacio na rua de Christovão Colombn, sem te: mais que o pĩo nogro da miseria para comor com truflas do Perizord, regulo com as lagrimas do abandoino e com o chantpazmo da vinvez de Mime. Clicqunot.

Foi n'esto horroroso desamparo que d nobre lusitano a encontrou consternata em tomo do lago no Bois do Boulogne. dentro do um misero coupé de maílís. le flechla o oito molas, envolta nos andrajos fornccidos pelo Worth ou pela Felix, a quem ella os pagava, para nã andar de todo en todo nua, om miserna - parperrimas contas de 10 a I5 contos le réis nor semestre.

0 germoso descondente de Virinto compungido em sua alma antiga peir miseria da fraca e delicada dama, gut ? proviloncia the faria oncontraresou surimo ma dolorosa via das nenrin

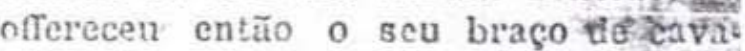
lheiro para a conduzir a jantar no caffe Anglais, an theatro n'uma Usignotve aravant-scine, $c$ ao mais que 6 mister para que uma lind 1 o abandonada crea. tura não pereça a mingua. prostrads sobre as frias lages das ruas

Júmais pela mento do luso passou, nem mesmo soba förma da mais remota, da mais inverosimil, da mais insensata hypotinose, a suspreita do que o sert acto de protecęão puiesso de aluxm mato ferir os sugrarlos compromissos domes. ticos da bolla repudiad. Mraitu Ea chaud, advogado do Jeronymo, demonstrou-o bem por meio de um notive movimento oratorio.

- Olhem-me para cssa scrhera que alii está cxelamou o jurisconsulto, c todo o trihunal considerou attentamento a acensua. Oliem-me para e!la, evil= gam-me se pote ter semelhante aspecto tma csposa e tima müi de familia! 
o Sr. Hart, cuj, depoimento màis fortes jomos de luz poderia lanc: 1 sotra. - ardor da fé conjugal de Atistress Ifart, achava-se infelizarente susente, tendo partido para Now-York Enmediatamente depois de constatido o aúlilerio

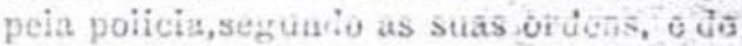
lavrato o competente uuto de corpo de deilicto.

0 advogato do tino Interessante maritio conseguiu, porim, defhonstrar que o casamento dos esposos Hart era perfeitamonte real e authontico; que Nistresg If r.t nio polla ter soinle esse pountc a minima duvida; e que o sen complice s6 po: insigne má fo finge ignomer ctile clla ern, so apparecarthe no fiocs. $\mathbf{a}$ matrona immaetiada como Lucreci, cone sarruda tos severus encirros to !a: wo

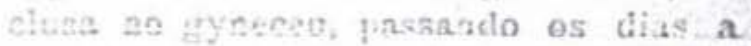
aprestru os manjares para seus tenrog Athos, quanio os viessa a ter, ou a far na roea o fino e casto linho para as piugas in sen unico o legitimo hument.

En vista de tal allagarino, o tilbunat condennou a if a tres mezes do prisĩo. e o co-réu a tres rnczes do pristo ac-n 100 fo tnene la mnita.

Nesta brove historia, destinada a con, sagrar mais uma vez a tirudicão amorosa que tem o caracter portuguez na historia da sentimentalidade, o episodio çac mais impressĩo causou om Lisboy, foi o preito de respeitosa consilleração prestada pelos juizes, pelos advogados c pelos jornalistas, no decurso d'este processo, a Jeronymo de Magalhäes, como represcritante do grande navegador do seculo:XVI..

- O resto cos Maga!hũes. slguns tresentos oll quatrocentos flalgos com esse mesmo appellido, protestan despeitados, aflirmando que Jeronymo usurpou um aro que the nũo perínce.
Illusão profunda da parte dos MagaThães queirosos.

Solte-se nunes os tramites do encarte bo um sujcito quilquer na nobreza porSugueza. Comeso-se por fazer um requerimento, attestando com o depoimento de duas testemunhas que o supplicantc, sel pai o scu aro foram creafos a lei da nobreza com crialos e cavallos e pedindo o fôro: paga-se o preço da taxa para esta especie de mercé, e - rei darmas Portugal passa a carta competente com o respectivo brasũo de armas, copiado a aquarella. dos escudos da sala das Pegas, o qual o agraciado fica ro: case documento antorisado a pỏr nas librés, nos reposteiros e: nas portinioias das carruagens. O sugeito chams-se Castron, dinc-se-lhe as armas de §. Joйо do $\mathrm{C}_{\mathrm{i}}$ '. , däo-sc-lhe as armas de 2 . Nuho Arrares Pereira. E desdo case momento o alludico Fereira, o alludito Castio, o Pereira de Castro ou o Castro Pereira, flzam legaimente pertencendo $\dot{A}$ fanilia do condesturcl ou it do viso-roi da India, ju ambos.

Eu mesmo conheci um homen, hoje nobre c titular, o qual antigamento se Shamavr apents Jo:̃o Fernandes. Um dia, da almotolia da regia munificencia pingou sobre o peito d'esse Јoũo uma commenda de Nossa Senhora da Concoisção de Villa Tiçosa. A commenda d'essa mui nobre ordem dá cumulativamente 20 egraciado o rêro de filalgo. Requereu-se a respectiva carta de nobrezd, r por ella se reio no conhecimento do que, feitas as dovidas investigáaues heraldicas no tecto da sala das Pèas, Joũo era um dos representanles da aritiga e noluilissima estirpe dos Fönandes, cujo brasão se the deu, flcando deste esse dia os verdadciros o iegitimos Joũes Fernandes com mais um nóvo primo direito na sua já tão numerosa quanto illustre familia. 
Ora, com os Magallutes succede preAisamente o mesine que se dá cora os Perciras, com os Castros e com os Ferjandes. Tolos elles, uma vez que so Pchem devidamente encartados, são igualnente nobres, igualmente illustres, igualmonte primos uns dos outros, etodos hetos igaaimonte leritimos dos competentes fundadores das surs respectivas casas.

Portanto, desde rue se trato de guem 6) que veruadeiramente representa hoje F่ernăo đ๋e Magalhùcs, fidalgo portuguez do quarto grâ, isto $屯$, de cota d'armas geraçio com insignias de nobreza, cu direi que o repiescntam, com ignal authenticitade o igual lustfe, todos aquelles flalgos subsequontes a quom ci-rei aosso sestror conferiu o diveito de usnrem o escudo darmas evxequelacio que ypa a buasto dos Magallixes a cûrte He D. Manuel.

Tuntonde-ge, partin, do maie arrnjato † Uo mais hevoico navegador do muncio: tratando-se do homem mafs que todos onsado, Gua descobrita o mat I'acifico e Aeronstrou experimentaimente a esphericidade ta torwa. Lanto psia primeira vez a rol:a us glolvo, e creardo assion a geogruphiamoterna: ruditeiqu etis at̃o tem represceturies, tem tem hardaitos. dentro do z zuiro ta aristocracia, pougle

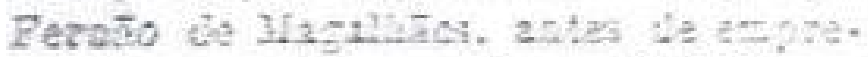
jencier a sua iamosa viagom is Molucas, pels America, tesnaturalizon-se da sua patrin e destituitu-se de todos os setis titulos de nobreza.

Flle cessou, desde ontio, te ger o fiủalgo, Jáca ser simplesmentri o heróe, e, sob sste áspecto, nũo ha scräo um unico Magalıães, quo logitimaments a represcnta no nutudo. e esso to a csireito, gua the herden o nome.

Ramalto Ommĩo.

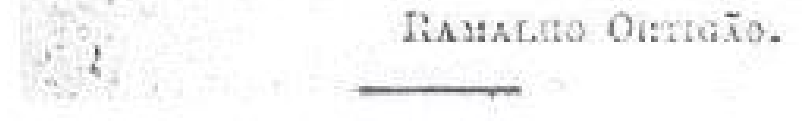




\section{CAMTR POTTEUULAS}

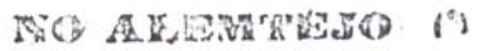

\section{7}

A cathedral d'Erora. $\rightarrow$ A irreja de S. Domingog a. $\because$ dos.Loyos, a te S. Francico e a do Santo taitso. - Carncter dit archilectura da Reuascuenga em Evorit.-Asjectos piftoresens. - A traliecto era-

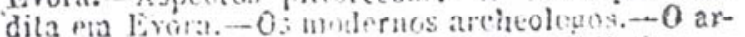

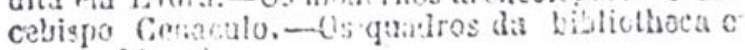
do arcebispalo.

A cathedrul, que, dopois da Sé Velua de Colmora, represonta um dos mellores documentas que possuimos de cyclo geralmente chamado gothico, $\dot{\theta}$ dos fins do seculo XII, emaloba da de aresta com tres naves o triforium. As nervuras da nbolada carectorisam bem, creio, o e.jtylo de transição do seculo x.IL para $\theta$ seculo XIII. O lnterior da igreja foi por duas rezes ralicalmente rostaurado. A entrads $\&$ da seculo XVI, o a capella mor $\theta$ do secula prisasla, om marmoro do Estremoz, construido pelo architecto allemão das obras do Mafra Jožo Fro. derico Ludorico.

Q granito das naves, rebocada a gesso em todus as juntas da pedra, perdeu um pouco da sia primitiva gravidado por esta meticuiosidade excessiva de conservação o mais ainda pelas intoleraveis janellas do secinlo xirl auertias no muro do lacio do claustro.

As esculpturns do calairal no. coro зи̃o elegantes c npresentam pequenas motivos deconativos do mais dolicado acabamento.

O exterior do templo está intacto e offerece um bello e nobre aspecto de conjuato con a cupolir ponteaguda vestida

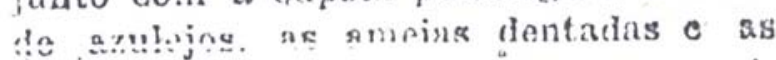
quatio gruaritis costalsia (échanguettes), na platuforma das torres.

o claustio, magnifico, acha-se mero soterrato peiz olevacão do solo na quadra interior, onde jazem sobrepostas varias geargoes de conegos á sombra dos tres majores e mais estranhos pilriteiros seculines que tenho visto.

a igreja de S. Firncisco, construida por D. Joño III o por D. Manuel, tem uin bello lay chire os melhores edifl. cios religioses da renuscenca portugueza. Aqui se encontra uma urna com as cinzes de (iil Vicento e at colebre casa cios osios, que pela grande quantidade de crincos quo revestem as tres naves de capella desse nome, constitus um interessinte nuseu osteologico.

Sũo notavels pur differentos titulos varias outras igrejas, taes como, por ezemplo: a dos Loyos foriada de bellos azulojos am grandes panneaux azues ? brancos do seculo XVIII, na qual se vừn as campas en bronzo doz ascendentes do duque do Cadaval no seculo $\mathrm{XV}$, e um curioso tumulo do marmore n'uma das capollas Iateraes, no qual, datado de ił@3, se encoutra jô o estylo du ronasença com og coracteristicos medallúcs applicados a parte exterior do estabelecimento, por pora da architrave; a de Santo Antro, com os sous curiosos azulejos polychromos de desenho gconectrico, o seu magnifico frontal de altar \& a velha capa do orego, trabalho semelhante ao dos paramentos de Toledo, devidos aos bordadores italianos do eculo XVI; a dia Misericordia com a\%ulejos de figura dacados de $1716 \overline{\text { um }}$ pouco inferiores aos dos Loyos, que tem a data de 1711 ; etc.

Os numeroses artistas mouriscos que depois da conquista de Granada pelos reis catholicos so estabeleceram em Portugal, a occupaçî́o de Evora por Abder liamau, a necessidade de occupar na cdiflcação das icrrejas o dos momumentos publicos artistus e operarios mouros durante os primeiros tempos da monarchia quando as christãos tinham apenus tempo para batulhar, süo factos que ezplicam suflicientemento a tendencia musaribu de quasi todas as edificaçũes de Evoria desto o seculo XII até o seculo XVI.

As construcções archiloctonicas são aqui como esses cavallos dn'Irlanda, da Andalụzia ou de Alter quo sem serom propriamente arabes, timn comtudo na sua geneologia uma porcentagem mais ou menos connịderavel, ainda que, as vezes, extremamente remota de sangue al- 
gelino.

A cada passo, no alto de velhos muros carcomicios de extinctós con rontos de fiadea o do frcin'ss, se vạ trunsparecer $\circ$ dia atravez dos quadrilhamentos de tijoio arabe en iórma do adura pintada de branco.

N'uma rua estreita, sobre a reentrancia de um crosso muro caiado, arqueaso uma peiquena janella mourisea, o uma espocio de mourinha, de cara redonda, morena, corada, assoma ao sol debrucancose sobre o craveiro de um póte de barro pousado no peitoril.

V'éso o arico manoelitio com toda a decoraciuo exterior do stylo flammante e a rolla de ferradura guarnocida por dentro de um recanto dis tijolo vermotho applicado ao marmore branco.

Nas casas do duque de Cadaval oncontram-se lindas janellas géminas do seculo XVI teir!o a esbelta columna central coroada pelo capitol arabe.

Ifa muitas outras curiosidades architectonicas.

Interess.ntes janelias angulares de casas de escuina de rua, em cujo cunhal o jeso da micissa cantaria se interrompe le reponte, um flno e dolicado columvelo de mirmore sorve do centro a dupla vidraca, e sobre essa columnazinha, gue so polerir cingir com un braceleta to mulher. o cuuhal continúa para cima tão intóndso e tão pesado como para balxo.

Alnum:s emlocaduras do rua sãa a mais frresistivel tentagito do piotores, poia oricinalldado de certos cunliaes do betlos, pela pittorusca valiedado das cousbinerints o polos ofroltoa da luz ousbecortala por mntigos passidilgos. Tha! bus ozen in, viala da rua da badalra, a

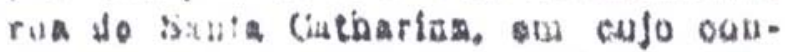

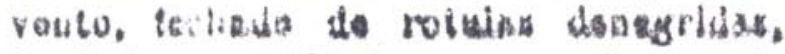

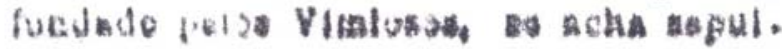

fada a princeas D. Dostria do Portugul,

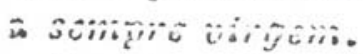

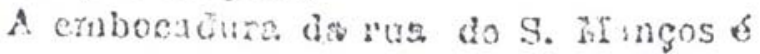
frabrectic de um e te outro lsto pa: duns solidas e pesades torras quadradas, la toinpo do dominfo rumano, feitus de pedras osquatriadas; regularmente ligar das entre Ei-opas acoum - Por antre cokes dois mommentos de conturis $c$ de argamassa dos Cozares vé-sa em trenti. st poucos passoz do distaracia, a janolla monoelina dis casa do licenciado Re\%entia. o so fundo, recortanto-se rijamento no sul, o muro smeiado o as torres de vigio

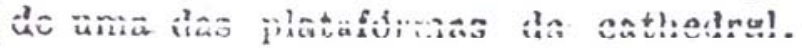

Ocalifcio de antigra universidade onde prosontemento so acha a casa pia o outras upartigues públicas, fem pouco de nninmum com a arte proprian anc dita mas a considumovelmente esperoso, ben! de-

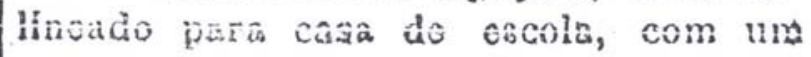

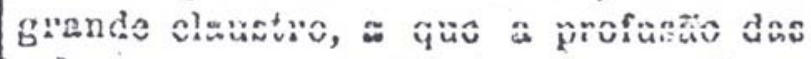
columnas em magniflco marmoro, dâ um certo ar de magestade o de opuloncia.

O amor aos cstudos de atcherilogia e de critica de erto e tradicional em Evora desde Danmiäo do Gúes e de André de Rezonde, cuos é ainda hoje para o estrangeiro o guia Baedoker da antiguidade oborinse.

Os frades que tomararia em seguraa a monopolio da crudiçüo, importavam-sa pouso corr as fontes da inspilaçãa popular em que se alinenta nara cada nacicmalidade o destino da sua arte. Cariservaram. jorom, as procisias alfaias da igroja, que, sem elles teriam talvez desapparecila na rarina conconitante das nossas commocoies mo!iticas. e guardaram. nos sens archiros e cartorios, ainda que sem perfeita conscicncia do seu valor historico, os documentos mais importan. tes yar'a o conlieclmento da nossu antigra. 
vida civil.

As tropas de D. João d'Austria durante as gnerras da restauraçio $\theta$ as do Laison por occusiño da invasĩo franceza do $180 \%$ saquenram a cidacle c destruiram muita cousa. Frej sinnul do Cenaculo Villas-Boals, primeiramento hisno de Boja o dopois arcobispo de Erorn, foí. quem pelos nus do seculo passada recomeçou a dar as graşos que se tho seguiram o exemplo do estudo o do apreço derpdo nos documentos archeolericos e untieticos.

Distincto naturalista o eonsummado antiquario, a arcebispo Cenaculo exercea na revinoscencia da educação artistíca on Portugal no corneço d'eate seculo um sympaihico papel semelhante ao que tem tillo modernamente na Hollands alguns ontroz memioros aminentes do clero catholico. Este instruido sacordote, párecondo tor comprehendido todo o mar que flzeram a igreja os que contwhuiram nara ahastardar ou para ciesa

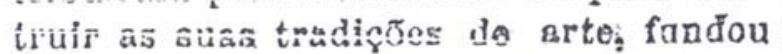
o nusor a que dea o seu nome o no qual recolheu todos os documentos hir. to:icos e prehistoricas que poudo colligir por si mesmo ou pela cooperaşão dos seus amigros, já na sua diocese, já nas nossas provincias ultramsrinas, $\mathrm{j} \hat{\alpha}$ om paizes estrangeiros, $\theta$ bem assin um

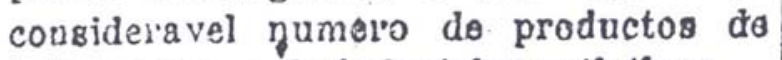
bellas-artes o de fndustrlas artisticas.

A maioy parte d'esta colleç̧ão, que primeiro estevo em Boja, passou para Evora com a nomeação de Conaculo para prelado d'esta diocese, e aqui flcou annexa á bibliatheca, quo o arcobispo enriqueceu $\operatorname{com}$ a doaçũo da'sua propris livraria.

Modernaniente os estudos arcneologicos e de critica de arte foram continuados em Evora por Cunha Rivara o por Angusto Filipne simões, ambos fallecidos.

IIoje todos os estudiosos quo chegam a Frora se dirigem ao Sr. Gabriel Pereira, que pelos seus vastos estudos se tornou, extra-onticialmente, o bibliothecurio-mor, o archivista o o conservador da cidade.

Na torro do Tombo ea Lisboa tinhamme fallado d'elle, como de uma especie de segundia torro, succursal do grande archivo e ambulanto ás tardes por baizo da alcada da rua Ancha.

Tremulo de religiosa commoç̃o e de vigo pevor, o fui procurar a porta do Canzulo, estabelecimento de barberro que em Evora representa o portico atheniengo da cliade, correspondente ao que são em Lisioga 03 umìrges dáa Casâ Hávaneza. Tinha-mo pieparado para encontrar no illustre antiquario cborense um monte de annos de paleographia e de rapé, feito de pergaminho e de retroz, com uma lombada antiga, amaiellecida de mofo e sevaadijada do gorgulho. Imaginem que, em $v e z$ d'isso, me apparece um homem lo trinla prinaveras, desernpenado, rijo, vestido a moda; com uma jaqueta ingleze e um chapéu còco, do bigode torcido o um charuto nos beiços! Apresso-me a consignar que foi esta a mais estranha curiosidade do todas quantas aqui vi. Porque esto homem é, com cfieito, um oruditissino antiquario, sem todavia ter nada de antigo. E' um archeologo com gostos de arte. E' um especialista com ideas geraes e encyclopa. dicas. A sua paleographia ñ̃o o impede do conhecer as linguas vivas e as littera-

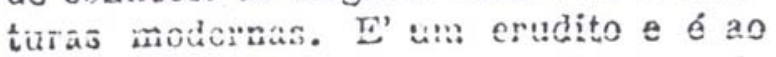
mesmo tempo um diletinte. Lê Inscripçees gothicas e romanas, e lo igualmonte Zola. Interpreta com facilidade um codice do seculo XII, a-Deus me perdoe so o calumnio con este juizo temeraríojulgo-o inteiramente capá de namoiar as muiherez e de dansar uma valsa. como quasquer outro. Sarito exemplo á mocilade moderna, que tão gresulnento cuida que a sua frescura de esplrito 6 atsolntumanta fuenmativel cou \& loitura de uma velta cluronica como conliecinento, a!cia quo muj rago e nebutuso, do hora-horce!

A blbliotliecs o o museu annezo, apezar

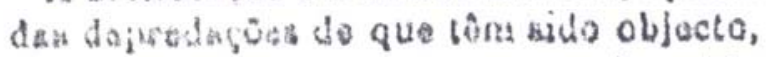

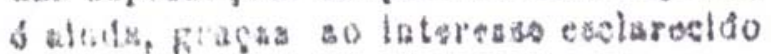
gua ob llie ligas, uma cullecgira impor-

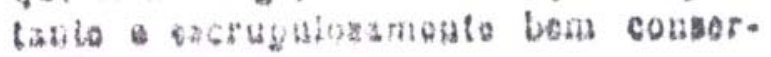
radis.

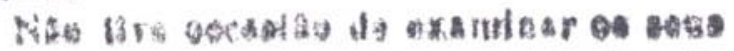

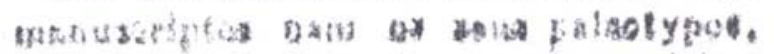

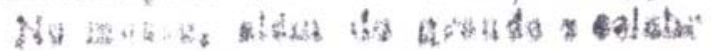


esmalte tryplico de Limoges, o do qua-

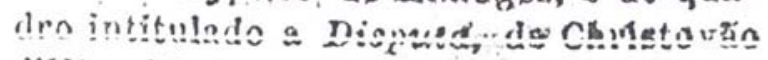
dUtrocht, ha uma riviosissima collecção ie disonlyas a lapus vermolho de Vieira Insitano, varias tóles do morgado de Sotubul e uma do Josedia d'oliø̄os.

Este uftimo quatarosjnho renresenta un cordelra branco pintado com sinBular srescura, mus insordor a umá pequene pintera on codre. a mesmia au. ctorn, representando uma santa framilia, e existento na cateria portuarso do S. Lazaro.

O morgado de Solubal, José Antonio

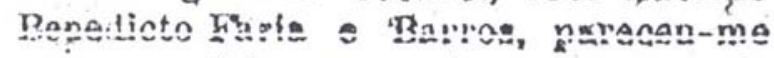
um sympathico mergado, com a mais doterminada quada nara a palheta, "mas com uma educaşro technica excesslva. mento rudimentar. Sentig a cur o a érma, msa a lyoi tintes snia, a a inganuidade do séu desonho iuvade ág vezes os dominios sciontilacos a exactos da porspectiva.

A Disputc faz parte de una collecç⿸尸o do doze quadros do izuaes dimensões tendo par assumplo a vida da Virgem. que so achum presentemente no paço dó arcebispo.

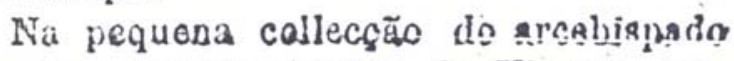
ha um giande quadro da Virgom, rodesia de anjos tocando vaylos Instramontos de riusica. Esto' 'quàdro, da opoca da escola flamenga ímmediatamente precedente a $0^{\circ}$ apparecimento da cscola hollandeza, lembras 55 mais bellas obras dos dous Van Eryck, das calhodracs e dos museus da Belgics. O conde Raczynski considera osta quadro o mais bollo gothico quo elle vill em Portugal, e efiectivamente não sei do qutro que so iine cuinparo.

Nũo cxplico o silencia do Raczynski, que vin todas estas têlas, a rèperto de um retrato a oleo $\mathrm{cm}$ meto cörpo que se acha na bibliotheca $\theta$ repuresentá um homem do seculo XVIr, de bigele o barbiche loura, coberto pos um cliapsu mollo do grandes abas. Este retrato, assignado por $A$. de Viries, felto de repente, n'um esboço da mais pol'erosa onergia, rivalisu com os do musen de Amstadam o faz pensar em Francz ilals.
De ondo vciu para o musou de Evora cato retrato, cujo. original $G$ orickentemente um homon do norto 9 Quem 6 A. de rries. cujo namo eu näo encontro em nenhum dos musous da Hollậua Vries (Viedernan) e um pintor de archtecturus to soculo XVI. e Vries (Joăo) 6 um paisagista da escola de Ruisdael.

São numerosos, on fortugal os quadros flamengos ou do influencia flamenga (esçola chamada do Grão Vasco) Antonio do Fiollagda, Christovam d'U. trecht. Gll Eane, viviar do Gzudi Van der Weydon, Bauts, Bosch, etc. Os hol landezes do secculo XVII são muito

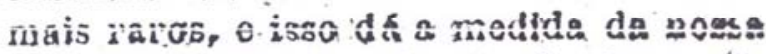
lecadencia artistica depois da Época a ก. Jo ̃̃o III, quando a raclonaldiado hollacleza se formava e a noșa se dissolria.

Que A. de Viles, tivesse ou não tivess estado om lortugal. olle $\mathrm{n}$ ฐ̄o constituiu aqui familia artistica como succodeu aos mestres flamengos.

Na pintura portugueza do sectaso XVII noda ha comparavel an retrato do musez do Everz, um puro c ganuino hollandez da melhor Epoca, perfoltamente authentico, o quo so ño podo dizer de alguna que sob a denominação da mesma escola Igar'am na museu de Lisboa.

Um proposito inteiramonte local e poculiar de Evora $\sigma 0$ do pendurar os quadros a maior altura a que se presta n paredo, junto do tecto. Esta especie de systema of principalmento affictiva nas salas do arcebispada. Se juntamenta com os meus comprimontos agradecidos pela amavel tolerancia com que recebeu a minha visita profana a sua collecçäo de arte, eu ousasso dirigir uma respeltosa petiçuo so venoravel prelado, solicitaria de sua excellencia reverendissima a gl'aça do dar aos sons paineis' uma disposiçaro mais confoume com a da.justiça divina, peranfe g qunl os merecimentos so contam de bairo para cima e não de cima para baixo. Eatle os qualros da galeria archepiscopal ha alguns, e nomeadamentc os de Christorāo a'Utrecht, a que näo podem sem aggravo recusal-se-como nos autros dizemos noz atelicrs-as honras da cimalha:

ralatho Ortigño. 


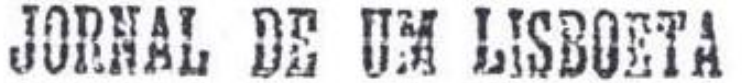 \\ V. 1s:3-Junho, 5.-Sorreu hontem An-} gelo Frandoni. Era Italiano. Veiu para Lisboa muito moço e falleceu com perto de 80 annos. Introduziu em Portugal a opera-comica c regeu por muitos annos a orchestra do theatro da Trindade. Compizz espirituosos trechos de musica ligeira e o mais popular dos hymnos portuguezes, o hymno do Minho. A grande ambição da sua vida cra fundar em Lisboa o ensino popular do eanto, creando um grande orpheon racional. Tendo passado toda a sua existencia na orchestra, no palco dos theatros, compantheiro fraternal ou paternal de todos os actores e de todas as actrizes. este homem conservou ate os seus ultimos dias a mais rara frescura de coracuio e de espirito. Dentro do sen alentado e robusto arcabouço de furriel de couraceiros habitara a alma candida de uma noviça. Morreu cercado dos seus fllios e dos seus netos, e um dos que assistiu á sua breve agonia contou que foi esta a sua ultima plirase : - Quanelo se vive como eu rivi, morre-se resignadoe contente.

Outro que tambem partiu para nunca mais voltar: o marquez de Bellas. Para as lisboetas de 50 annos, quantas recordaçóes de mocidade alliadas an nome aristocratico d'este pobre morto!

Fintre a geração terceira do marquez de Castello Melhor e de Frcderico Ferreira Pinto, dos Manicques e dos Gala.ches, 0 marquez de Bellas era o cavalleiro que mais elegante e mais puramente mantinha as tradiçoes da gineta do tempo de Marialva e de Vimioso.
O solar de Bellas, com o seu labirintho de murtas, as suas rastas frondosas alamedas seculares, as suas quedas d'agua, o seu grande sanctuario do Senhor da Sirra, a que se subia ao ar livre por uma escadaria entrecortada đe grutas, a casa nolsre ornamentada de grandes paineis, de azulejos entre arcarias gothicas, era um dos mais bellos exemplares da casa nolire rortugneza, aberta tolos os annos, senlorialmente, ás festas do poro e ao agasalho da amisade. No tempo em que a quinta de Bellas pertencia a infanta D. Brites, mãi de D. Manuel, conta João de Burros que n'ella se achava o tumulo de Viriato com a lezrenda Hic jacet $\mathrm{T}_{i}$ riutus lusitunarim dux. Pelo homisio de Diogo Lopes Pacheco, nm dos assassinos de D. Ignez de Castro, a quinta que the pertencia por uma troca feita com as commendadeiras de santos no principio do seculo XIV, foi confiscada e tornou-se por aigum tempo propriedade real. Foi D. Pedro I que por amor a estes logares, a que o prendia um vago sentimento de saudade e de ternura, mandou edificar o palacio de Bellas, que elle habitou por muitas vezes assim como D. Ioin, o mestre de Aviz, c n Rei D. Duarte. No principio do seculo XVI a infanta D. Beatriz tę doaçăo da quinta e sanhorio de Bellas a Rodrigo Afronsn de Athongria, e foi por casamento de uma bisneta d'este com $0^{\prime} 12^{\prime}$ senhor de Pombeiro, D. Antonio de Castello Branco, que a propriedado entrou na familia dos condes de Pombeiro, de que o marquez agora fallecido cra o ultimo representante.

A casa de Bellas tinha, como a quinta, a sua lencla. Todos os amigos do marquez que alguma vez foram hospedados por elle, sabem que, segundo uma antiga tradição, o phantasma de Roque Furtado Paim, da casa de Tolamim Paim, que veiu da Inglaterra con a rainha D. Fiiippa, vagueava a deshoras poins salas e pelas rocionde\%as do palacio, c mais de um relbs criado, pallido de susto, affirmava ter ouvido fallar, nas solidũes de certas noites propicias aos mortos, o espectro benigno, como o do pai de flamlet nos terraços de Elsencur. 
O marquez de Bellas, agora fallecido era o XI conde de Ponbeiro, o XX senhor (c) Pombciro, o XIV senhor de Bellas. O seu bisavó I). Luiz de Castello Branco, capitio da guarda real, casado com D. Polagia d'Almada, era ainda senhor dos morgados de Castello Branco e Pombeiro, alcaide-mór de Villa Franca de Xira c dis villa de El-Rei, commendador de Santa Maria da Amendoa e Oitavos na Ordem de Christo, padroeiro do Mosteiro da Conceição dos Arrahidos e da igreja de S. Salvador de Pombeiro e de S. Martinho e do logar da Cortiça, ete.

Na familia do marquez de Bellas ha pelo lado das mulheres sangue dos princípes de Suubise e dos principes de Rohan. Entre os seus antepassados conia-se Vasco Paes de Castello Branco, neto de Suciro Eannes de Payra, de quem trata - Nobiliario do conde D. Pedro como tendo ji então uma antiga varonia; Lopo Vaz de Castello Branco, manteiro-mór de D. Joũo I; D. Duarte de Casteliu Brasco, alcaide-mór de Moura, que se bateu em Ceuta ; Gonçalo Vaz de Castello Branco, escrivão da Puridade e vedor da fazenda de 1 . Afronso $V$, e senhor de Villa Nora de Portimão; Nuno Vaz de Castello Branco, almiraute, manteiro-múr, senlor da Bambarral, etc.
A quintr co pracio de Bellas foram ha poucos anuos vendidos a um burguez abastado. A agua das cascatas, que enchiam de doces murmurios aquelle valle, foi adquirida pcla companhia das aguas, c, reunida i do Alviella, corre agora nos contalores de Lishon.

0 marquez, tendo alienado successivamento em pagamento de antigos encargos os bens herdados de sua familia, restando-lbe apenas de todos os sous antigos direitos e dominios um pobre escudo d'armns, com um leão de ouro rompente armado de vermelbo em campo azul, morreu cm Santarém, onde exercia o modesto emprego de sub-inspector da Penitenciaria.

Sobrevive-the sua mãi, a condessa de Pombeiro, cujo marido, flel ao partido de D. Miguel, não quiz nunca emquanto vivo acceitar o titulo de marquez referendado por soberanos do regimen liberal. Esta desditosa senhora é avs de trinta netos, cujas caricias não bastarảo de certo para apagar da sua alma a lembrança do todas as amarguras que tem passado no mundo. 
Junho, 6.-Dous lindos Watean-um da rainha, outro segundo se lê no respectivo rotulo, de Ame. Brameamp-na exposiçĩo de leques e miniaturas, com que o conde de Almedina teve a graciosa idéa de restajar no musen de bellas artey a chegauda do verão: Alèrn d'estes cious leques primorosos, mais dez ou doze solfriveis, e todos os outras rulgares.

Fomos nós portuguezes os primeiros cecidentaes que penetraram na China.

De li trouxemos de certo. juntamente om as primciras porcellanas, os primeiros leques de varetas que se usaram na Europa. Na sociedade de Lisboa o apparecimento dos leques data do seculo XVI. Entao se lhes chamava abano ou abanico, c condiz a primitivo uso d'elles com a moda das golas altas, lisas ou encanubatas, a que na Re:ıascença so dava isnalmente o nome de abanos, gola ou colar de abanos.

O abano leque dobrou rapidamente de volume tomando a fórma curopia de melo circulo, em vez. do quarto de circulo do formato Chinez.

$O$ abano collarinho attinge proporçð̃es phenomenaes, como se vê no gorjal fransirio dos retratos de Luiz de Camóes, do rei D. Sehastiano e dos Huguenotes em França. Inventou-se uma colher esperial de cabo cumprido para poder co mer sīpa, tendo o pescoço ornado com o aristoeratico gorjal á moda, e um rei do França Henrique III, inventou uma gomma especial de farin!na de arroz, para luo dar a consistencia precisa.

Nas senhoras de alta categoria a gola de abano, era umas vezes franzida em canudos sobrepostos, outras vezes lisa, perpendicular ao decote, armado em aras me, na fórma de um veriadeiro panno do leque.
Durante o inverno findo as senhoras da burguezia do Lisboa, renovando o abano gorgete da Renascença, fizeram d'elle o mais reprehensivel alento. Estariam muito bam se o trouxnssem como Maria de Melices com toilette de baile, em ponto de Veneza ou em ponto de Inglaterra, do renda cntretecida de ouro e bordada de perolas. Mas em traje de passeio o abanr ol raco e espesso, feito do mesmo estofo do restido, não lembra senão um niisero abano de fogarciro de assar castanhas, e í a coisa mais espantantemente presumida, mais snobica e mais labregamento delirante que ha.

Da exposição a que me refiro vẽ-se que da jarte da maioria das senhoras que expuzeram o leque nũo foi certamento objecto de uma prelilecçũo de lnxo tăo absorvente como a que deu em epidemia nelos cabscũes dos restidos.

So dos centenares de leques de que se compöe este certamen exceptuarmos uma duzis d'elles, serú preciso o mais forto impu!so de prodigalidade e de dissipaçāo para dar por qualquer dos outros seis libras.

0 que determina o valor artistico do um leque é a pintura do panno. A materia prima, mais ou menos preciosa, do que elle é fabricado não tem señó uma cotação puramente industrial. 0 leque do seculo passado, o leque francez, o leque Regencia, o leque pintado por Fragonard, por Watteau, por Boucher é o typo do afcrição para todo o leque de caracter artistico. Ora, nenhum leque da época referida se comprava novo, em primeira mito, por menos de 800 francos. Este preço hoje tresdobrou, porque o lindo leque do seculo XVIUI assumiu presentemente um grande augmento de importancia na historia da arte. Reconbece-se hoje que foi exercendo o frivolo o minoso trabalho de fizer cantar as allegorias o bailar as pastoraes nos leques das nossas avós, quie or radestos discipulos de Greuse, de Frudbon, de Chardin e de La Tour vulgarisaram e mantiveram desde 0 seculo XVIII até o fin d'este seculo a doce tralição de uma arte de meiga intinidacle, que em nossos dias sobresaltados c entristecidos sorri ainda na obra moderna de Chapelain, de Leloir, de Forluny e de Sala, de Madeleine Lemaire e do Kate Greenawy. 
A miniatura, tendo tido a sua origem nas illuminuras dos missaes e dos lirras de horas da Edade Média, e.chegando ao seu mais alto poder de expressão no seculo XVIII e nos primeiros annos d'este seculo sob as pinceis de Hall, do Duchesne, de Rosalba Carrora, de Mme. do Mirbel e de Mme. Herbelin contribuiu fixada pelo esmalte ao cabul e á porcellana para ennobrecer pela arte um grande numero de modestos utensilios do sanctuario domestico: cofres, estojos, taças, cairas de tabaco, cairas de paetilinas, a. jullieiros, frascos de saes.

Fm Portugal a miniatura foi talrez d'entre ns artes do descnbo aquella quo até o descobrimento do daguerreoly po exerceu com mais sequencia e mais engenho. E' grando e ininterrompida a sćric dos artistas portugnezes dedicados a este genero de pintura, que Fsterăo Gionçalves Netto tion gloriosamente iliustrou c que rarios estrangeiros como Tillement, Josć Throno e José Viale, cultiraram tambem, já cm Lisbos, jk no Porto, durante 0 seculo passado e no principio d'este seculo. D'essa lista fazem parte muitos nomes de senhors: a infanta D. Filippa, Alha do infante D. Pedro o neta do mestre d'Ariz, a qual se attribue o lindo retratinho do infante D. Henrique como se acha illustrado o manuscripto da chronica de Azurara, D. Bernarda Ferreira de Lacerda, D. Joseta de Ayala, e mais recentemente $\boldsymbol{D}$. Isaivel hiaris Rite. matiemoiselle Lorrele, D. Síchaeia Arcangela Romanete, e D. Francisca de Almeida Furtado, filha do tnustre miniaturista de Vizeu, José de Almeida Furtado, e irmã do meu antigo mestre de desenho Thadeu Maria de Almaida Furtado.
Uma exposiçāo-como que foi.promovida pelo conde de Almedina parece devêria sêr o meio mais praticú de avertguar o destino đ'esses interessantes producto3, mas t.yrez ainda occultos em Portugal entre ignoradas e intimas recoriaçöes de familia, outras transforidas a colleccionadores estrangeiros come succedeu á Chronica de Guiné, a quo acima me refcrt, á famosa arrore geneslogica de D. Manuel, que está no museu de Londres, a maior parte dos espirituosos esbocetos de Vicira Lusitaco, e a tantag ontras obras primas da nossa arte nacional.

E apezar de tudo isso a exposição do miniaturas das Janellas Verdes não deu idéa nenhuma do que é ou de que foi a arte da minialura em Portugal. Alguns bonitos cofres francezes ou italianos das collecsĩes do conde de Danpias, do conde de Durnay, ou do marquez da Foz, e alguns raros reiratinhos de familis, sem indicação de auctor, foi tudo o que appareceu.

0 amarel conde d'Almedina, expondo com sympathico arrojo esmaltes de Sèvres, do Sü̈r ous do Retiro, fa!sificalos por Sanson, o miniataras do tempo de Loria XV c de Luiz XVI, feitas em Pariz ba tres ou quatro annos, mostrou quo o sea encargo de inspector das bellas artes nāo torna accintosamente severo com a 
culta camelotte da rua de Rivoll e da rua Lafayette.

Rsto exemplo do longanimidade não é talrez dos mais instruetivos e poderá induxir $\mathrm{cm}$ equivocos funestos os que andem estudando para criticos. Pela minhs parte porém acho que i sempre muito bonito, para quem póde, proteger por meio de compra as artes todas, bellasartes e malas-artes, embora uma ou outra rez os resultados financciros d'esta virtude se manifestem para os que a exercem sob a infelizmente bem conhecida forma- de espiga.

Junho, 15.-Com assombro gera! da praça falliu ha dias em condiçores phantasticas o banco Lusitano, ao qual o governo concedeu uma moratoria.

Pouco mais ou menos pelo mesmo tempo foi a pique, abalroado por uma barca das obras do porto, o vapor tamben Lusitano, da carreira de Cacilhas.

De um fragmento de jornal, encontrado agora entrc os meus papeis, salta-me aos olhos este fim de noticia.

" Foi retirado do fundo o Lusitano, mas vein cheio de lodn.

"A que é que se refere esta boa nova: \& ao banco ou é ao vapor? Não sei, nem a fallar a verdade me importo muito com tsso. Mas diz-me um negociante meu amigo que só pela analyse do lodo cu me poderia tirar d'csta duvida, porque ha muito mais scdimento de porcaria no fundo de um estabelecimento de credito do que no fundo de um rio.

Ramalio Ortigão.

(Direito de transcripe;io reservado). 
Bibliografia consultada

Abdala Jr., B. (org.), Ecos do Brasil, São Paulo, Editora Senac, 2000.

Almeida, L. N., A comunidade luso-brasileira, Rio de Janeiro, 1969.

Almeida, V. de, À janela de Tormes, Lisboa, Editora da Revista "Ocidente", 1945.

Alves, O. R., Os homens que governaram São Paulo, S. Paulo, Liv. Nobel, 1986.

Arquivo da Casa de Rui Barbosa, Correspondência de Rodolfo E. de Souza Dantas,

Rio de Janeiro, Casa de Rui Barbosa, 1973.

Barbosa, M. de L., Rui Barbosa na política e na história, Rio de Janeiro, F. Briguiet e Cia Editores, 1916.

Basto, A. de M., Figuras literárias do Porto, Porto, Livraria Simões Lopes, 1947.

Berardinelli, C., Estudos de literatura portuguesa, Imprensa Nacional-Casa da Moeda, 1985 (Vila da Maia).

Calmon, P., Franklin Dória - Barão de Loreto, Rio de Janeiro, Biblioteca do Exército Editora, 1981.

Carneiro, L., Dois arautos da democracia: Rui Barbosa e Joaquim Nabuco, Rio de Janeiro, Casa de Rui Barbosa, 1954.

Cartas da biblioteca Guita e José Mindlin, São Paulo, Ed. Terceiro Nome, 2008.

Cavalcanti, P., Eça de Queiroz, agitador no Brasil, São Paulo, Cia Editora Nacional, 1966.

Cavalheiro, R., A evolução espiritual de Ramalho, Lisboa, Livraria Clássica Editora, 1962. , Homens e idéias, Lisboa, Livraria SamCarlos, 1960.

Coelho, A. do P., Ensaios críticos, Liv. Aillud e Bertrand, Paris-Lisboa, 1919.

Conde de Sabugosa, Neves de antanho, Lisboa, Livraria São Carlos, 1974.

Cortes, G. de M., Migração e Colonização no Brasil, Rio de janeiro, Liv. José Olympio Editora, 1958.

Cunha, C. V., No tempo de Paula Nei, São Paulo, Saraiva, 1950.

Faro, A, Eça e o Brasil, São Paulo, Editora Nacional/ Edusp, 1977.

Ferreira, A., Estudos de cultura portuguesa (séc. XIX), Lisboa, Moraes, 1980.

Figueiredo, F. de, Depois de Eça de Queirós, São Paulo, Editora Clássico-Científica, 1943. 
História da literatura realista, Lisboa, Liv. Clássica Ed., 1914.

Freyre, G., Perfil de Euclides e outros perfis, Rio de Janeiro, Livraria José Olympio Editora, 1944.

Gazeta de Notícias, consultada de 2 de agosto de 1875 a 30 de novembro de 1915.

Haidar, M. de C. Mariotto, O ensino secundário no império brasileiro, São Paulo, Grijalbo/Edusp, 1972.

Jacques, P., O governo parlamentar e a crise brasileira, Brasília, Editora da Universidade de Brasília, 1982.

Lima, O., O império brasileiro, São Paulo, Edições Melhoramentos, 2ª edição, s/d.

Lins, A., Rio Branco, Rio de Janeiro, José Olímpio, 1945.

, História literária de Eça de Queirós, Porto Alegre, Liv. Globo, 1945.

Machado, A. M., A geração de 70: uma revolução cultural e literária, Instituto de Cultura Portuguesa, 1977.

Machado, A., Brasílio Machado (1848-1919), Rio de Janeiro, José Olímpio, 1937.

Martins, L., O patriarca e o bacharel, São Paulo, Livraria Martins Editora, 1953.

Medina, J., Eça de Queiroz e a geração de 70, Lisboa, Moraes, 1980. Eça de Queirós antibrasileiro? , Bauru, Edusc, 2000.

Menezes, R., A vida boêmia de Paula Nei, Rio de Janeiro, Tecnoprint, 1968.

Miné, E., Eça de Queiroz jornalista, Lisboa, Livros Horizonte, 1986.

, Páginas flutuantes, Cotia, Ateliê Editorial, 2000.

Moniz, H., O 2º reinado, Rio de Janeiro, Leite Ribeiro Editora, 1928.

Monteiro, G., Vencidos da vida, Lisboa, Edição Romano Torres, 1944.

Monteiro, H. M., Brasil república, São Paulo, Ed. Ática, 1990.

Monteiro, T., Pesquisas e depoimentos, Paris-Rio de Janeiro, Aillaud, Alves \& Cia, 1913.

, O presidente Campos Sales na Europa, Belo Horizonte, Editora Itatiaia/ Edusp, 1983.

Moog, C. V., Eça de Queiroz e o século XIX, Rio de Janeiro, Civ. Brasileira, 1966.

Moreira, A. e Abreu, B. de, Novas cartas inéditas de Eça de Queirós a Ramalho Ortigão, Rio de Janeiro, Alba Editora, 1940.

Motta Filho, C., A vida de Eduardo Prado, Rio de Janeiro, José Olímpio, 1967. 
Muralha, P., Portugal no Brasil: a colonização portuguesa, Lisboa, Tipografia Lusográfica, 1927.

Napoleão, A., O segundo Rio-Branco, Rio de Janeiro, Editora A Noite, 1941.

Nabuco, C., A vida de Joaquim Nabuco, Rio de Janeiro, José Olímpio/ INL/MEC, 1979.

Nabuco, J., Minha formação, Rio de Janeiro/Paris, H. Garnier, 1900.

, Escritos e discursos literários, São Paulo, Progresso Editorial, 1949.

, Trechos escolhidos, por Carolina Nabuco, Rio de Janeiro, Livraria Agir Editora, 1967.

Nunes, J de C., Alguns homens do meu tempo (memórias e impressões), Rio de Janeiro, José Olímpio Editora, 1957.

Oliveira, M. J. L. Ortigão de., O essencial sobre Ramalho Ortigão, Lisboa, Imprensa Nacional - Casa da Moeda, 1989.

Ortigão, R., A Holanda, Lisboa, Livraria Clássica Editora, 1947, 2v. , As farpas, Lisboa, Livraria Clássica Editora, 1948, 15 v. Arte portuguesa, Lisboa, Livraria Clássica Editora, 1943, 3v.

, Banhos de caldas e águas minerais, introdução de Júlio César Machado,

Lisboa, Livraria Clássica Editora, 1944.

, Cartas a Emília, intr., sel., fixação do texto, comentários e notas de Beatriz

Berrini, Lisboa, Lisóptima Edições-Biblioteca Nacional, 1993.

, Contos e páginas dispersas, Lisboa, Livraria Clássica Editora, 1945.

, Correio de hoje (1870-1871), Lisboa, Livr. Clássica Editora, 1948, 2v.

, Costumes e perfis, Lisboa, Livraria Clássica Editora, 1944.

, Crônicas portuenses (1859-1866), Lisboa, Livr. Clássica Ed., 1944.

, Em Paris, Lisboa, Livraria Clássica Editora, 1943.

, Farpas escolhidas, introdução e seleção de Rodrigues Cavalheiro, Lisboa,

Editorial Verbo, 1971.

, Farpas esquecidas, Lisboa, Livraria Clássica Editora, 1956, 2v.

, Figuras e questões literárias, Lisboa, Livr. Clássica Editora, 1945, 2v.

, Notas de viagens - Paris e a exposição universal (1878 - 1879), Lisboa,

Livraria Clássica Editora, 1945.

, Pela terra alheia, Lisboa, Livraria Clássica Editora, 1949.

, Primeiras prosas (1859-1867), Lisboa, Livraria Clássica Editora, 1944. 
, Últimas farpas (1911 - 1914), Lisboa, Livraria Clássica Editora, 1946.

Ortigão, R. e Queirós, E., As Farpas, seleção e prefácio de Gilberto Freyre, Rio de Janeiro, Edições Dois Mundos, 1943, 2v.

Pacheco, J., A literatura brasileira, v.III, o realismo, São Paulo, Cultrix, s/d.

Porto, C., Pinheiro Machado e seu tempo, Rio de Janeiro, José Olímpio, 1951.

Prado, E., Viagens, São Paulo, Escola Tipográfica Salesiana, 1902.

, Trechos escolhidos, por Mário Casasanta, Rio de Janeiro, Livraria Agir Editora, 1959.

Queiroz, E., Notas Contemporâneas, edição de Luís de Magalhães, Porto, Livraria Chardron, 1909.

, Cartas inéditas de Fradique Mendes, São Paulo, Editora Brasiliense, 1961. , Correspondências, Porto, Lello \& Irmãos Editores, s/d. , Cartas, São Paulo, Editora Brasiliense, 1961. , "In memoriam", Lisboa, Livraria Editora, 1922.

Queirós, E. e Reis, J.B., Cartas e recordações do seu convívio, escritos coligidos e apres. por Beatriz C. Batalha Reis, Porto, Lello \& Irmão-Editores, 1966.

Queirós E. e Ortigão R., O mistério da estrada de Sintra, Lisboa, Livraria Clássica Editora, 1947.

Rego, A. da S., O ultramar português no séc. XIX (1834-1910), Lisboa, Agência Geral do Ultramar, 1966.

Rego, A. M., Nabuco, São Paulo, José Olympio, 1951.

Reis, C., "Ramalho Ortigão", in As questões morais e sociais na literatura, Lisboa, Seara Nova, 1941.

Reis, L. da C., "Ramalho Ortigão", in Perspectiva da literatura portuguesa do século $X I X$, direção, prefácio e notas bio-bibliográficas de João Gaspar Simões, Lisboa, Edições Ática, 1947.

Reis, J. B., O descobrimento do Brasil intelectual pelos portugueses do século XIX, org., pref. e notas de Elza Mine, Lisboa, D. Quixote, 1988.

Resende, J. S., Eduardo Prado, páginas de crítica e polêmica, São Paulo, Falcone Editores, s/d.

Rocha Pombo, História do Brasil, Jackson editores, Rio de Janeiro, 1953.

Saraiva, A. J., As idéias de Eça de Queiroz, Lisboa, Centro Bibliográfico, s/d. 
A tertúlia ocidental: estudos sobre Antero de Quental, Oliveira Martins, Eça de Queirós e outros, Lisboa, Gradiva, 1990.

Sergio, A., "Eça de Queiroz e a sociedade portuguesa", in Ensaios, Lisboa, Inquérito, 1946, v. III.

Serrão, J., Temas oitocentistas, II, Lisboa, Portugália, 1962.

Silva, C., Floriano Peixoto, o consolidador da república, São Paulo, Editora Edaigeit, 1963.

, Quintino Bocaiuva, o patriarca da república, Brasília, Editora Universidade de Brasília, 1983.

, Pinheiro Machado, Rio de Janeiro, Livraria Tupã, s/d.

, Rio-Branco, Rio de Janeiro, José Olímpio, 1945.

Silva, H. e Carneiro, M. C. Ribas, Nasce a república, São Paulo, Editora Três, 1975.

, Os presidentes - Prudente de Morais, São Paulo,

Grupo de Comunicação Três, 1983.

Sodré, N. W., História da imprensa no Brasil, São Paulo, Civilização Brasileira, 1966. , Panorama do 2o império, São Paulo, Cia Editora Nacional, 1939.

Sousa e Costa, J. de, Ramalho Ortigão - memórias de seu tempo, Lisboa, Edição Romano Torres, 1946.

Simões, J. C., Vida e obra de Eça de Queiroz, Lisboa, Livraria Bertrand, 1980, 3ª edição revista.

Tengarrinha, J., História da imprensa periódica portuguesa, Lisboa, editorial Caminho, 1989.

Vaz de Carvalho, M. A., Alguns homens de meu tempo: impressões literárias, Lisboa, Empresa Literária Fluminense, 1889.

Viana Filho, L., A vida de Rui Barbosa, São Paulo, Martin Editora, 1965.

A vida de Joaquim Nabuco, São Paulo, Companhia Editora Nacional, 1952.

A vida do Barão do Rio Branco, Rio de Janeiro, José Olympio, 1959.

Vieira, C. da C., No tempo de Paula Nei, São Paulo, Coleção Saraiva, 1950.

Vieira, C., Joaquim Nabuco "libertador da raça negra", São Paulo, Progresso Editorial, 1949. 
Vieira,N. H., Brasil e Portugal - $A$ imagem recíproca ( $O$ mito e a realidade na expressão literária, Icalp, Ministério da Educação, 1991.

Visconde de Taunay, $O$ encilhamento, São Paulo, Companhia Melhoramentos de São Paulo, s/d. 